\title{
Dietary protein in the regulation of the somatotropic axis
}

Citation for published version (APA):

van Vught, J. A. H. (2009). Dietary protein in the regulation of the somatotropic axis. [Doctoral Thesis, Maastricht University]. Universitaire Pers Maastricht. https://doi.org/10.26481/dis.20091030jv

Document status and date:

Published: 01/01/2009

DOI:

10.26481/dis.20091030jv

Document Version:

Publisher's PDF, also known as Version of record

\section{Please check the document version of this publication:}

- A submitted manuscript is the version of the article upon submission and before peer-review. There can be important differences between the submitted version and the official published version of record.

People interested in the research are advised to contact the author for the final version of the publication, or visit the DOI to the publisher's website.

- The final author version and the galley proof are versions of the publication after peer review.

- The final published version features the final layout of the paper including the volume, issue and page numbers.

Link to publication

\footnotetext{
General rights rights.

- You may freely distribute the URL identifying the publication in the public portal. please follow below link for the End User Agreement:

www.umlib.nl/taverne-license

Take down policy

If you believe that this document breaches copyright please contact us at:

repository@maastrichtuniversity.nl

providing details and we will investigate your claim.
}

Copyright and moral rights for the publications made accessible in the public portal are retained by the authors and/or other copyright owners and it is a condition of accessing publications that users recognise and abide by the legal requirements associated with these

- Users may download and print one copy of any publication from the public portal for the purpose of private study or research.

- You may not further distribute the material or use it for any profit-making activity or commercial gain

If the publication is distributed under the terms of Article $25 \mathrm{fa}$ of the Dutch Copyright Act, indicated by the "Taverne" license above, 
DIETARY PROTEIN in the REGULATION of the SOMATOTROPIC AXIS 


\section{iffín}

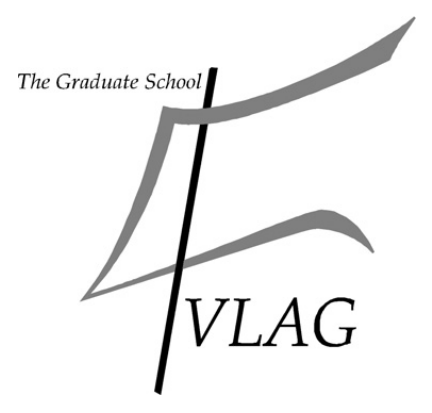

The studies presented in this thesis were preformed at the Nutrition and Toxicology Research Institute Maastricht (NUTRIM), which participates in the graduate school VLAG (Food technology, Agrobiotechnology, Nutrition and Health Sciences), accredited by the Royal Netherlands Academy of Arts and Science.

Cover design:

Layout:

Printed by:
Vin Baltussen www.vormidabel.nl

Anneke van Vught

Datawyse, Universitaire pers Maastricht

C Copyright JAH van Vught, Maastricht 2009

Universitaire Pers Maastricht

ISBN 978-90-5278-864-7 


\title{
DIETARY PROTEIN in the REGULATION of the SOMATOTROPIC AXIS
}

\author{
PROEFSCHRIFT \\ ter verkrijging van de graad van doctor \\ aan de Universiteit Maastricht \\ op gezag van de Rector Magnificus \\ Prof. mr. G.P.M.F. Mols \\ volgens het besluit van het College van Decanen \\ in het openbaar te verdedigen \\ op vrijdag 30 oktober 2009 om 10:00 uur \\ door \\ Johanna Adriana Henrica van Vught
}

Geboren te Boxmeer op 24 mei 1982

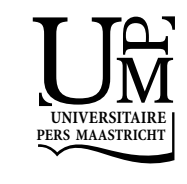




\section{Promotoren}

Prof. dr. M.S. Westerterp-Plantenga

Prof. dr. R-J.M. Brummer

\section{Co-promotor}

Dr. A. Nieuwenhuizen

\section{Beoordelingscommissie}

Prof. dr. K.R. Westerterp (voorzitter)

Dr. G. Johannsson (Sahlgrenska University Hospital, Göteborg, Sweden)

Prof. dr. W. Lamers

Dr. C. Noordam (UMC St. Radboud, Nijmegen)

Prof. dr. N. Schaper

The research described in this thesis was supported by Top Institute Food and Nutrition.

Financial support by the "Jurriaanse Stichting" for the publication of this thesis is gratefully acknowledged. 


\section{Content}

Chapter 1

Introduction

Chapter 2

Effects of oral ingestion of amino acids and proteins on the somatotropic axis

Chapter 3

The effects of dietary protein on the somatotropic axis; a comparison of soy, gelatin, alpha lactalbumin and milk

\section{Chapter 4}

Somatotropic responses to soy protein alone and as part of a meal

Chapter 5

Somatotropic effects of soy protein in relation to the presence of carbohydrate and fat

\section{Chapter 6}

Association between intake of dietary protein and 3y-change in body growth among normal and overweight 6y old boys and girls (CoSCIS)

\section{Chapter 7}

Association between dietary protein and change in body composition among children (EYHS)

\section{Chapter 8}

Pharmacological and physiological growth hormone stimulation tests to predict successful GH therapy in children

\section{Chapter 9}

Acute ingestion of gelatin protein normalizes blunted $\mathrm{GH}$ concentrations in visceral obesity

\section{Chapter 10}

General Discussion

Summary/ Samenvatting

Dankwoord

Curriculum Vitae 



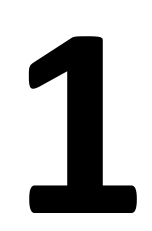

Introduction 
The somatotropic axis originates in the hypothalamus (brain region) and pituitary gland (beneath the hypothalamus). Through the central release of growth hormone $(\mathrm{GH})$ and peripheral production of insulin-like growth factor 1 (IGF-1), the somatotropic axis is involved in linear growth and intermediary metabolism ${ }^{1}$. Disorders as visceral obesity, sarcopenia and growth retardation in children are characterised by a low activity of the somatotropic axis ${ }^{2-5}$. Several amino acids, building blocks of protein, and protein itself are previously found to stimulate the activity of the somatotropic axis ${ }^{6-13}$. This stimulating potential is investigated in this thesis from a neuroendocrinological, physiological and pathophysiological perspective. This chapter gives an overview of the concepts underlying the studies, starting with the neuroendocrinology, i.e. the regulation of the somatotropic axis. It continues with the physiologal effects of GH and IGF-1, including linear growth and intermediary metabolism, and the pathophysiology of the somatotropic axis, i.e. the consequence of a reduced somatotropic activity. Furthermore a section on dietary protein and its role in the regulation of the somatotropic axis is provided, finishing with an overview of the research questions investigated in this thesis.

\section{REGULATION OF THE SOMATOTROPIC AXIS}

The secretion of $\mathrm{GH}$ by the anterior pituitary is pulsatile and mediated by two neurohormones ( $\mathrm{GH}$ releasing hormone (GHRH) and somatostatin), which are produced by the hypothalamus and continually influence the secretory rate of $\mathrm{GH}$. Both hypothalamic peptides are secreted in independent waves and interact together to generate and control GH release. GHRH stimulates $\mathrm{GH}$ release, whereas somatostatin has an inhibitory effect ${ }^{14-17}$. Both GHRH and somatostatin are transported via a portal blood system from the hypothalamus to the anterior pituitary gland and bind to specific receptors in the pituitary to influence the production of $\mathrm{GH}$ by the somatotrophs (cells in the anterior pituitary gland that produce $\mathrm{GH}$ ). The integrated effect of GHRH and somatostatin on the pituitary gland ultimately leads to $\mathrm{GH}$ secretion in a pulsatile pattern with about $10-20$ secretory pulses per $24 \mathrm{~h}^{18}$. Pulses of $\mathrm{GH}$ secretion occur at times of maximum GHRH and minimum somatostatin secretion ${ }^{19,20}$. Recently, ghrelin, a hormone from the stomach, is investigated suggesting a new mechanism for regulation of $\mathrm{GH}$ secretion via a specific receptor in the somatotrophs ${ }^{13}$.

Daily GH secretion rate varies from a maximum of nearly 2 milligram per day in late puberty to a minimum of 20 microgram per day in older and obese adults ${ }^{21}$. The differences in the amount of $\mathrm{GH}$ secretion during life are explained by changes in GH pulse amplitude, with unchanged GH pulse frequency. GH pulse amplitudes decline with age and $\mathrm{GH}$ concentrations in middle age are about $15 \%$ of pubertal 
levels. Both men and women have an increased pulse frequency during the night time hours ${ }^{21}$. Fasting GH concentrations are higher in women than in men. Overall, women have more continuous $\mathrm{GH}$ secretion and GH pulses that are of more uniform size than men. Major $\mathrm{GH}$ secretory pulses, accounting for approximately $70 \%$ of daily GH secretion, occur in the deep sleep, i.e. slow wave sleep (SWS). The decline in SWS from early adulthood to midlife is paralleled by a major decline in $\mathrm{GH}$ secretion, suggesting that age-related alterations in the GH-IGF-1 axis may partially reflect decreased sleep architecture ${ }^{21}$.

Thus, the GH secretory pattern is characterized by diurnal pulses and therefore accurate quantification of $\mathrm{GH}$ secretion requires extra attention, to exclude missing pulses. Frequent sampling of every $20 \mathrm{~min}$ has been shown to be an appropriate manner to quantify the $\mathrm{GH}$ secretion ${ }^{22}$.

\section{Stimulators and inhibitors of the somatotropic axis}

The balance of stimulating and inhibiting peptides determines $\mathrm{GH}$ release and is influenced by factors as sex, ageing, stress, sleep, body composition and food intake. These factors can be mediated on neural, metabolic and hormonal level. An overview of the somatotropic regulation is shown in Figure 1.

Neural- Neural stimulators and inhibitors affecting GH release include neurotransmitters ${ }^{21,23}$. Dopaminergic, alpha-adrenergic and serotonergic agents all stimulate $\mathrm{GH}$ release. For instance, levodopa (i.e. a dopaminergic agonist) and norepinephrine (alpha-adrenergic pathways) increases $\mathrm{GH}$ secretion and propranolol (i.e. betaadrenergic agonist) inhibits $\mathrm{GH}$ secretion ${ }^{23}$.

Metabolic- Changes in the levels of metabolic fuels play an important role in regulation of GH secretion. When glucose concentrations are decreased, i.e. hypoglycaemia, GH secretion is stimulated. Insulin-induced hypoglycaemia is used clinically as a test to provoke $\mathrm{GH}$ secretion ${ }^{24}$. Acute ingestion of glucose results in an elevated plasma glucose concentration and inhibits GH secretion, although there is a rebound release 3-4 $\mathrm{h}$ later after glucose ingestion as a consequence of decreasing glucose concentrations ${ }^{25} 26$.

With respect to the role of fat, there is clear evidence that free fatty acids (FFA) control the GH secretion. Pharmacological reduction of circulating FFA raises GH secretion ${ }^{23}$ and FFA elevation induced by the combination of exogenous intralipid plus heparin reduces spontaneous $\mathrm{GH}$ secretion ${ }^{23,27}$ and abolishes $\mathrm{GH}$ responses to various stimuli ${ }^{23,28,29}$. The inhibitory effect of FFA on GH secretion at the pituitary is rapid, within minutes and is dose and time dependent ${ }^{30}$.

Furthermore, infusion or ingestion of certain amino acids (AA) increases GH secretion ${ }^{73}$. The most well known GH promoting AA is arginine ${ }^{31}$. Intravenous administration of arginine is used clinically as a test to provoke $\mathrm{GH}$ secretion ${ }^{32-34}$. Also 
other AA have been shown to promote GH release, in particular lysine, ornitine, glutamine, methionine, histidine, tyrosine, glycine and tryptophan, but not leucine and valine ${ }^{7,9-11}$. The influence of amino acids and protein on the somatotropic activity is extensively dealt within this thesis.

Hormonal- GH secretion is affected by numerous hormones. Estrogen enhances the $\mathrm{GH}$ secretory response to many stimuli, and the same holds for prolactin and gonadotropins ( $\mathrm{LH}$ and FSH). Furthermore ghrelin stimulates the secretion of GH from the somatotrophs. Ghrelin is high just before a meal and is stimulated by ingestion of protein, but suppressed after a meal by ingestion of carbohydrates or fat ${ }^{35,36}$. GH release is suppressed by progesterone, glucocorticoid therapy, hypercortisolism, hyperthyroidism and hypothyroidism ${ }^{23}$. Circulating leptin concentrations, which are positively correlated with abdominal and total body fat ${ }^{37}$, are inversely related with serum $\mathrm{GH}$ concentrations ${ }^{38,39}$. Furthermore, $\mathrm{GH}$ itself exerts a negative feedback on its own secretion. Also elevated IGF-1 concentrations (as a result of elevated $\mathrm{GH}$ concentrations) inhibits the $\mathrm{GH}$ release by a negative feedback loop ${ }^{30,40}$. Both GH and IGF-1 stimulate somatostatin secretion and inhibit $\mathrm{GHRH}^{41,42}$.

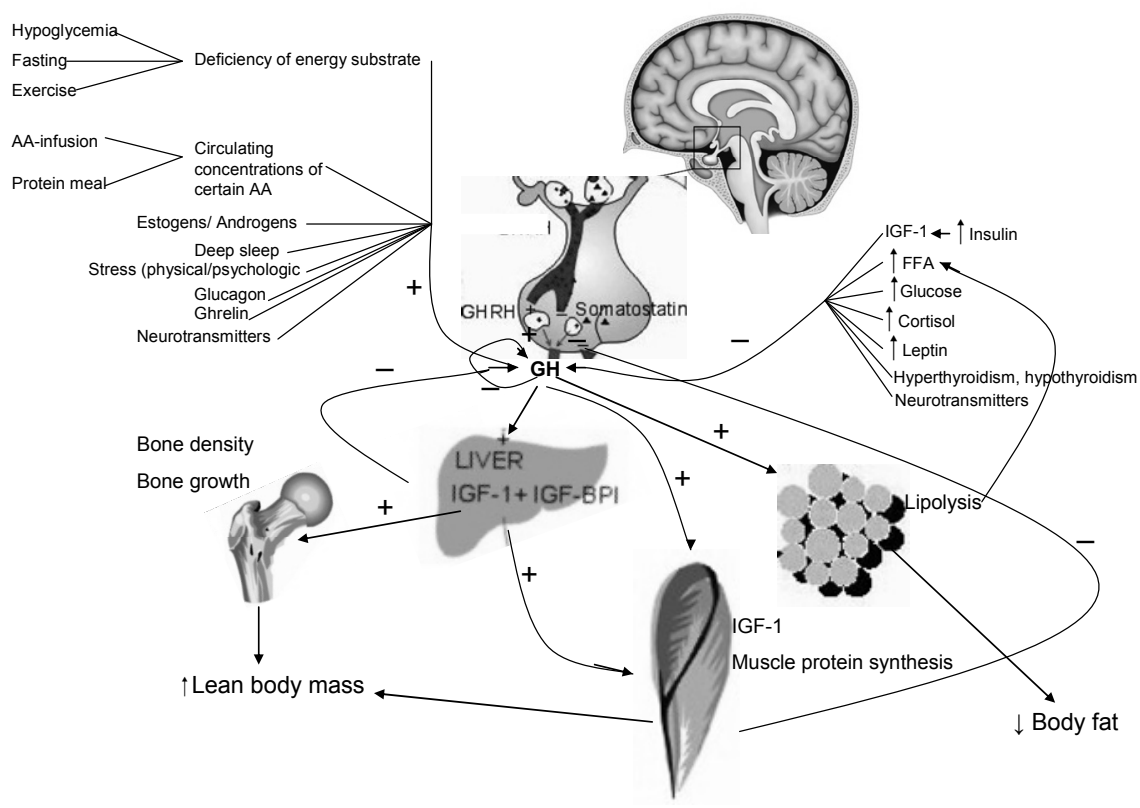

Figure 1: The regulation of the somatotropic axis. 


\section{Physiological effects of GH}

The meaning 'growth hormone' is derived from its ability to produce an increase in linear growth. Furthermore, the hormone plays an important role in the regulation of metabolic processes. The physiological effects of GH are summarized in Figure 1.

\section{Linear growth}

Longitudinal growth occurs through a process of cell proliferation, the addition of new cells to the growth plate of the bone and hypertrophy, resulting in the expansion of the growth plate ${ }^{43}$. Although the control of bone growth is not entirely understood, the somatotropic axis plays a key role in these processes. IGF-1 receptors are found in proliferating bone condrocytes, and IGF-1 itself stimulates synthesis of collagen ${ }^{44}$. Also from epidemiological studies it is known that the somatotropic axis is associated with linear growth in infancy, childhood and puberty. Increased IGF-1 concentrations and subsequently an increased growth velocity determines the growth curves of each individual child ${ }^{45-49}$.

\section{Metabolism}

Besides the impact of the somatotropic axis on linear growth, many metabolic effects that persist throughout life are affected by the hormones of the somatotropic axis. More specific, GH has acute and chronic metabolic effects on lipid, glucose and protein metabolism. More prolonged GH exposure induces IGF-1 production ${ }^{50}$, which is accompanied by an increase in lean body mass and a decrease in body fat, in particular the visceral component, in adults ${ }^{51}$. Metabolic effects of GH on fat, glucose and protein metabolism are described below.

Effects of GH on fat metabolism were already demonstrated in the 1930's when studies showed that the injection of rats with extracts from the anterior pituitary gland reduce body fat. Subsequent studies administrated $\mathrm{GH}$ subcutaneously and demonstrated that the decrease in body fat is caused by $\mathrm{GH}^{52-55}$. Injection of $\mathrm{GH}$ results in an increase in fat mobilization, oxidation, decrease in fat deposition and activation of hormone sensitive lipase, resulting in increased triglyceride hydrolysis to free fatty acids and glycerol (lipolysis) ${ }^{56-58}$, resulting in elevated blood FFA concentrations. The lipolytic action of $\mathrm{GH}$ is a direct effect and may underlie the ability of $\mathrm{GH}$ to decrease the excessive levels of adipose tissue, in particular in the visceral regions ${ }^{59-64}$. Furthermore, GH clearly shifts fuel utilization by increasing lipid oxidation and reducing carbohydrate and protein oxidation, probably by means of substrate competition ${ }^{65}$.

In addition to the effects of GH on fat metabolism, several effects of $\mathrm{GH}$ on glucose and protein metabolism are reported. Acute effects of $\mathrm{GH}$ on glucose metabolism include an impairment in muscle glucose uptake, together with a decrease in glucose oxidation, an increase in glucose storage ${ }^{65-69}$ and a diminished gluconeo- 
genesis ${ }^{58}$. The increase in $\mathrm{GH}$ concentrations is suggested to play a role in mediating the switch from gluconeogenesis to lipolysis ${ }^{70}$.

Somatotropic effects on protein metabolism include a stimulated protein anabolism in many tissues. GH, via IGF-1 increases protein synthesis by enhancing amino acid uptake and directly accelerating the transcription and translation of mRNA. As described above, $\mathrm{GH}$ tends to decrease protein catabolism by mobilizing fat as a preferred fuel source. This protein saving effect is an important mechanism by which GH promotes growth and development of lean body mass $50,70,71,72$. The anabolic effects of $\mathrm{GH}$ becomes more consistent with prolonged $\mathrm{GH}$ exposure, as also illustrated in acromegaly (a syndrome that results when the pituitary gland produces excess $\mathrm{GH}$ ) resulting in an increased $\mathrm{LBM}^{51,73}$.

Overall, the metabolic effects of GH on the somatotropic axis include an increase in the lipolysis, fat mobilisation, activation of hormone sensitive lipase, triglyceride hydrolysis and a decrease in fatty acid reesterfication ultimately resulting in a reduction of fatmass and change of fat distribution from visceral towards peripheral fat. Furthermore, an increase in somatotropic activity results in increased rates of whole body proteolysis, synthesis of protein, underlying an increase in lean body mass in the long term.

\section{Pathophysiology of the somatotropic axis}

A diminished or absent secretion of $\mathrm{GH}$ from the anterior pituitary gland, also called GH deficiency (GHD), is characterised by a reduced linear growth in children, increased body fat, in particular in the visceral regions, and decreased lean body mass ${ }^{74,75}$. GHD occurs in congenital pituitary deficiencies, pituitary adenoma or other disorders that are characterised by chronic damage of the pituitary gland or hypothalamus. ${ }^{42,7677,78}$.

Children with GHD usually present with short stature and low growth velocity for their age and pubertal stage ${ }^{79}$. Furthermore their weight is normal for their height, however their absolute lean mass is reduced and their absolute fat mass is unchanged compared with controls, which implies an unfavourable body composition. The diagnosis GHD in childhood involves a multiple step diagnostic process, usually culminating in GH stimulation tests (GHST) to identify whether the pituitary gland is able to release a pulse of $\mathrm{GH}$ when provoked by various stimuli as arginine, clonidine, insulin, levodopa or GHRH ${ }^{80,81}$. In children, GHST are used to estimate the level of insufficient $\mathrm{GH}$ secretion in order to decide about starting $\mathrm{GH}$ therapy 82. $\mathrm{GH}$ therapy consists of administration of recombinant human $\mathrm{GH}$ ( $\mathrm{rhGH}$ ) to restore IGF-1 concentrations ${ }^{83,84}$, resulting in an increase in linear growth in children who are too small for their age ${ }^{85-87}$, with an improvement in body composition development ${ }^{2}$. 
Besides in GHD, a diminished GH secretion can also occur in patients with a normal hypothalamus/pituitary gland, but with a chronic disease as the metabolic syndrome ${ }^{88}$; this state is called hyposomatotropism. Similarities exist between patients with hyposomatotropism and GHD. For instance, adults with the metabolic syndrome and adults with GH deficiency are both characterised by relatively high visceral adipose tissue, insulin resistance, high serum triglyceride (TG), concentrations, low serum high-density lipoprotein (HDL) cholesterol concentrations and an increased prevalence of hypertension and increased mortality from cardiovascular diseases 48 8, 89 . With increased visceral fat mass, GH secretion is blunted with a decrease in the amount of GH secreted per burst but without any major impact on GH secretory burst frequency ${ }^{90}$. Similar to $\mathrm{GH}$ concentrations, IGF-I concentrations are inversely related to the percentage of body fat ${ }^{90}$, and in particular to the amount of visceral adipose tissue and not to the amount of subcutaneous fat mass 91. Replacement therapy with rhGH has demonstrated favourable effects on most of the metabolic abnormalities of GHD in adults ${ }^{92}$. Similar to rhGH treatment in GHD, rhGH treatment in visceral obesity has shown to reverse the metabolic abnormalities, resulting in a decrease in visceral/abdominal fat mass, increase in lean mass, improvement of insulin sensitivity, but also improvement of the lipid profile and reduction of cardiovascular risk factors ${ }^{89,93}$.

\section{DIETARY PROTEIN and SOMATOTROPIC AXIS}

\section{Dietary protein}

Dietary protein has two general roles in nutrition, a specific role as source of amino acids (AA) and a non-specific role as energy source. Nine of the 20 nutritionally important $A A$ are classified as essential $A A$, i.e. cannot be synthesised by the body and must be supplied with the diet and the remaining $11 \mathrm{AA}$ are classified as nonessential, i.e. can be synthesised in the body from other AA. In humans, the essential AA are; histidine, isoleucine, leucine, lysine, methionine, phenylalanine, threonine, tryptophan and valine. The non-essential amino acids are alanine, arginine, asparagine, aspartic acid, cysteine, glutamine, glutamic acid, glycine, proline, serine and tyrosine ${ }^{94}$. Furthermore, conditionally essential AA are AA that need the donation of either a carbon or an accessory group from another amino acid in order to be synthesized. These AA include arginine, cysteine, glutamine, glycine, proline and thyrosine ${ }^{95}$. AA that are essential for adults are also essential for children.

Dietary protein is found in almost all foods of animal and plant origin. Sources of dietary protein are thus all kinds of meat and fish, eggs, dairy products, cereals, vegetables and legumes, such as beans or peas. Dietary protein of different sources 
are characterized by different AA compositions. Proteins are classified in relation to their nutritional quality, based upon the composition of AA and the amount of each amino acid. High-quality protein indicates an optimal amino acid composition of dietary protein, according to the needs of each amino acid. In general, animal sources of dietary protein, except gelatin, contain all essential amino acids and are therefore considered protein of high quality ${ }^{96}$.

The protein requirement of an individual is defined by the WHO as the lowest levels of dietary protein intake that will balance the losses of nitrogen from the body in persons maintaining energy balance at modest levels of physical activity ${ }^{97}$.The recommendation is 0.83 gram per kg body weight per day for adults and 1 gram per kg body weight for children between 6-10 y. Children from industrialised countries will typically have a protein intake that meets or exceeds their physiological requirement.

\section{Dietary protein and somatotropic axis}

Amino acids are potent stimulators of GH secretion, either intravenously injected or orally ingested ${ }^{6-13}$. Arginine is the most well-described stimulant, although lysine, ornithine, glutamine, methionine, histidine, tyrosine, glycine and tryptophan are all considered effective $\mathrm{GH}$ releasers ${ }^{7}$. An oral mixture of arginine and lysine evokes a sevenfold increase of plasma GH concentrations compared with basal concentrations ${ }^{8}$, and a similar effect is observed after arginine-aspartate ${ }^{98}$. The effect of AA on GH secretion appears to be exerted through suppression of hypothalamic SS release ${ }^{99-101}$.

Since AA are the building blocks of protein, it is likely that also proteins are involved in the somatotropic regulation, which is supported by epidemiologic studies in children and adults ${ }^{102-109}$. In intervention studies with extra protein consumption as intervention, IGF-1 concentrations were increased ${ }^{102,103}$. The same result is found in observational studies, in which the group with the highest tertile of milk intake showed higher IGF-1 concentrations than the group with the lowest tertile of milk intake ${ }^{104,105}$.

No short-term studies are performed investigating the somatotropic regulation by protein. For some decades ago, some studies already investigated the effect of a meal on the somatotropic axis. It has been reported that after a high protein meal, $\mathrm{GH}$ secretion is increased ${ }^{110}$ and after a high-carbohydrate meal, $\mathrm{GH}$ secretion is initially decreased, but increased in late postprandial phases ${ }^{111}$. However, no change in $\mathrm{GH}$ concentrations were found after 1 week of a low carbohydrate, high fat and high protein diet ${ }^{112}$. Another study found that high carbohydrate diets suppress GH secretion, whereas high fat diets and high protein diets of similar caloric value have no measurable effect ${ }^{28}$. The reason for the inconsistence of the studies is unclear, it may be that the different techniques to assess $\mathrm{GH}$ secretion 
result in inconsistency in the results. Furthermore it may be that differences in macronutrient composition are involved, as mentioned before, also the macronutrients glucose and fat are involved in the somatotropic activity $28,110,111,113,114$. No previous studies were performed investigating the specific effect of carbohydrate, fat or a combination of these, on the somatotropic axis by protein.

There are indications that not only the amount of protein, but also the protein type is an important factor in the elevation of circulating IGF-1 concentrations, probably due to various AA compositions of different protein types. For instance, animal protein including milk, fish and poultry, but not red meat was associated with higher IGF-1 concentrations. Moreover ingestion of milk protein increased the IGF1 concentrations, whereas the same amount of animal protein, ingested as meat, did not. In children IGF-1 concentrations were strongly associated with animal protein, but not with vegetable protein consumption ${ }^{106,107,109}$. This, together with the observation that some AA are more potent $\mathrm{GH}$ stimulators than others, indicates that the somatotropic activity of protein depends on the protein type. However, it is unknown which types of protein are more potent than others and if, ultimately, a possible variability in protein type differently influences linear growth and body composition. Hence this urges for systematic studies elucidating the capacity of various proteins, alone or as part of a meal to stimulate the somatotropic axis.

Thus, to understand the role of dietary protein in the regulation of somatotropic activity it is important to get insight in the somatotropic activity of different protein types and of protein as part of a meal. Furthermore, it remains to be investigated whether the somatotropic effects of protein can be used as tool in the diagnostic work-up of GHD or as nutritional therapeutic intervention to restore GH concentrations in hyposomatotropism.

\section{OUTLINE OF THE THESIS}

The studies described in this thesis investigate to what extent the dietary intake of protein affects the somatotropic axis from a neuroendocrinological, physiological and pathophysiological perspective.

From literature it is known that $A A$ are involved in the neuroendocrine regulation of the somatotropic axis. Since AA are the building blocks of protein, it is likely that proteins, similar to $A A$, are involved in short term somatotropic regulation. This hypothesis is tested in chapter 2 , where we investigated the somatotropic activity of protein, either in its complete form, hydrolysed form or as single AA. Since different proteins contain different AA compositions, we hypothesized that the various protein types differently affect the somatotropic release (chapter 3 ). 
A typical meal consumed by humans consists of a mixture of 3 macronutrients and each of the macronutrients may have an independent effect on the somatotropic release. Chapter 4 and 5 describe whether and how the somatotropic activity of protein is influenced by co-ingestion of carbohydrates and fat.

The physiological role of GH includes linear growth and body composition development. The hypothesis that protein and in particular the amino acids arginine and lysine stimulate the somatotropic axis, resulting in an increased linear growth (i.e. body height), increased lean body mass and decreased body fat is tested in epidemiological observational cohort studies (chapter 6 and 7).

A diminished or absent secretion of $\mathrm{GH}$ from the somatotrophs is a characteristic of the pathophysiology of the somatotropic axis resulting in a reduction in linear growth and an increase in visceral adipose tissue. Tests to evaluate the activity of the somatotropic axis in order to decide starting GH therapy are reviewed in chapter 8 and at the same time an alternative approach using dietary protein is suggested. In order to investigate the somatotropic activity of protein in lean subjects in comparison to that in a hyposomatotropic population, a study was executed to compare the $\mathrm{GH}$ promoting effect of dietary protein in lean subjects and visceral obese subjects, which is described in chapter 9.

Finally chapter 10 provides a general discussion that deals with the short term and long term effects of protein ingestion on the somatotropic axis and concomitantly on linear growth and body composition in lean and hyposomatotropic subjects. 


\section{REFERENCES}

1. Johannsson G, Rosen T, Lonn L \& Bengtsson BA. Effects of recombinant human growth hormone on adipose tissue in adults with growth hormone deficiency. Acta Paediatr Supp/ 1994 406 60-63; discussion 64.

2. Veldhuis JD, Roemmich JN, Richmond EJ, Rogol AD, Lovejoy JC, Sheffield-Moore M, Mauras N \& Bowers CY. Endocrine control of body composition in infancy, childhood, and puberty. Endocr Rev 200526114 146.

3. Scacchi M, Pincelli Al \& Cavagnini F. Growth hormone in obesity. Int J Obes Relat Metab Disord 199923 260-271.

4. Johannsson G \& Bengtsson BA. Growth hormone and the metabolic syndrome. J Endocrinol Invest 1999 22 41-46.

5. Hameed M, Lange KH, Andersen JL, Schjerling P, Kjaer M, Harridge SD \& Goldspink G. The effect of recombinant human growth hormone and resistance training on IGF-I mRNA expression in the muscles of elderly men. J Physiol 2004555 231-240.

6. Welbourne TC. Increased plasma bicarbonate and growth hormone after an oral glutamine load. Am J Clin Nutr 199561 1058-1061.

7. Knopf RF, Conn JW, Fajans SS, Floyd JC, Guntsche EM \& Rull JA. Plasma Growth Hormone Response to Intravenous Administration of Amino Acids. J Clin Endocrinol Metab 196525 1140-1144.

8. Isidori A, Lo Monaco A \& Cappa M. A study of growth hormone release in man after oral administration of amino acids. Curr Med Res Opin 19817 475-481.

9. Groschl M, Knerr I, Topf HG, Schmid P, Rascher W \& Rauh M. Endocrine responses to the oral ingestion of a physiological dose of essential amino acids in humans. J Endocrinol 2003179 237-244.

10. Collier SR, Casey DP \& Kanaley JA. Growth hormone responses to varying doses of oral arginine. Growth Horm IGF Res 200515 136-139.

11. Chromiak JA \& Antonio J. Use of amino acids as growth hormone-releasing agents by athletes. Nutrition 200218 657-661.

12. Biller BM, Samuels MH, Zagar A, Cook DM, Arafah BM, Bonert V, Stavrou S, Kleinberg DL, Chipman JJ \& Hartman ML. Sensitivity and specificity of six tests for the diagnosis of adult GH deficiency. $J$ Clin Endocrinol Metab 200287 2067-2079.

13. Lorenzi T, Meli R, Marzioni D, Morroni M, Baragli A, Castellucci M, Gualillo O \& Muccioli G. Ghrelin: a metabolic signal affecting the reproductive system. Cytokine Growth Factor Rev 200920 137-152.

14. Goodman HM, Schwartz Y, Tai LR \& Gorin E. Actions of growth hormone on adipose tissue: possible involvement of autocrine or paracrine factors. Acta Paediatr Scand Suppl 1990367 132-136.

15. Harant I, Beauville M, Crampes F, Riviere D, Tauber MT, Tauber JP \& Garrigues M. Response of fat cells to growth hormone (GH): effect of long term treatment with recombinant human $\mathrm{GH}$ in GH-deficient adults. J Clin Endocrinol Metab 199478 1392-1395.

16. Lonn L, Johansson G, Sjostrom L, Kvist H, Oden A \& Bengtsson BA. Body composition and tissue distributions in growth hormone deficient adults before and after growth hormone treatment. Obes Res 19964 45-54.

17. Lengyel AM. Novel mechanisms of growth hormone regulation: growth hormone-releasing peptides and ghrelin. Braz J Med Biol Res 200639 1003-1011.

18. Rosenfeld RG, Albertsson-Wikland K, Cassorla F, Frasier SD, Hasegawa Y, Hintz RL, Lafranchi S, Lippe B, Loriaux L, Melmed S \& et al. Diagnostic controversy: the diagnosis of childhood growth hormone deficiency revisited. J Clin Endocrinol Metab 199580 1532-1540.

19. Snyder DK, Clemmons DR \& Underwood LE. Treatment of obese, diet-restricted subjects with growth hormone for 11 weeks: effects on anabolism, lipolysis, and body composition. J Clin Endocrinol Metab 198867 54-61.

20. Vaisman N, Zadik Z, Akivias A, Voet H, Katz I, Yair S \& Ashkenazi A. Changes in body composition, resting energy expenditure, and thermic effect of food in short children on growth hormone therapy. Metabolism 199443 1543-1548.

21. Cone RD, Low MJ, Joel K.Elmquist \& Cameron JL. Neuroendocrinology. In Williams textbook of Endocrinology, p 121, 2008. 
22. Albertsson-Wikland K, Rosberg S, Karlberg J \& Groth T. Analysis of 24-hour growth hormone profiles in healthy boys and girls of normal stature: relation to puberty. J Clin Endocrinol Metab 199478 1195-1201.

23. Muller EE, Locatelli V \& Cocchi D. Neuroendocrine control of growth hormone secretion. Physiol Rev 199979 511-607.

24. Hoeck HC, Vestergaard P, Jakobsen PE \& Laurberg P. Test of growth hormone secretion in adults: poor reproducibility of the insulin tolerance test. Eur J Endocrinol 1995133 305-312.

25. Frystyk J, Grofte T, Skjaerbaek C \& Orskov H. The effect of oral glucose on serum free insulin-like growth factor-I and -II in health adults. J Clin Endocrinol Metab 199782 3124-3127.

26. Roth J, Glick SM, Yalow RS \& Bersonsa. Hypoglycemia: a potent stimulus to secretion of growth hormone. Science 1963140 987-988.

27. Blackard WG, Hull EW \& Lopez A. Effect of lipids on growth hormone secretion in humans. J Clin Invest 197150 1439-1443.

28. Merimee TJ, Pulkkinen AJ \& Burton CE. Diet-induced alterations of hGH secretion in man. J Clin Endocrinol Metab 197642 931-937.

29. Fineberg SE, Horland AA \& Merimee TJ. Free fatty acid concentrations and growth hormone secretion in man. Metabolism 197221 491-498.

30. Casanueva FF, Borras CG, Burguera B, Lima L, Muruais C, Tresguerres JA \& Devesa J. Growth hormone and prolactin secretion after growth hormone-releasing hormone administration, in anorexia nervosa patients, normal controls and tamoxifen-pretreated volunteers. Clin Endocrinol (Oxf) 198727 517-523.

31. Merimee TJ, Lillicrap DA \& Rabinowitz D. Effect of arginine on serum-levels of human growth-hormone. Lancet 19652 668-670.

32. Tillmann V, Buckler JM, Kibirige MS, Price DA, Shalet SM, Wales JK, Addison MG, Gill MS, Whatmore AJ \& Clayton PE. Biochemical tests in the diagnosis of childhood growth hormone deficiency. J Clin Endocrinol Metab 199782 531-535.

33. Donaubauer J, Kratzsch J, Fritzsch C, Stach B, Kiess W \& Keller E. The treadmill exhausting test is not suitable for screening of growth hormone deficiency! Horm Res 200155 137-140.

34. Youlton R, Kaplan SL \& Grumbach MM. Growth and growth hormone. IV. Limitations of the growth hormone response to insulin and arginine and of the immunoreactive insulin response to arginine in the assessment of growth hormone deficiency in children. Pediatrics 196943 989-1004.

35. Erdmann J, Lippl F \& Schusdziarra V. Differential effect of protein and fat on plasma ghrelin levels in man. Regul Pept 2003116 101-107.

36. Shiiya T, Nakazato M, Mizuta M, Date $Y$, Mondal MS, Tanaka M, Nozoe S, Hosoda H, Kangawa K \& Matsukura S. Plasma ghrelin levels in lean and obese humans and the effect of glucose on ghrelin secretion. J Clin Endocrinol Metab 200287 240-244.

37. Fisker S, VahI N, Hansen TB, Jorgensen JO, Hagen C, Orskov H \& Christiansen JS. Serum leptin is increased in growth hormone-deficient adults: relationship to body composition and effects of placebo-controlled growth hormone therapy for 1 year. Metabolism 199746 812-817.

38. Tuominen JA, Ebeling P, Laquier FW, Heiman ML, Stephens T \& Koivisto VA. Serum leptin concentration and fuel homeostasis in healthy man. Eur J Clin Invest 199727 206-211.

39. Tuominen JA, Ebeling P, Heiman ML, Stephens T \& Koivisto VA. Leptin and thermogenesis in humans. Acta Physiol Scand 1997160 83-87.

40. Hartman ML, Clayton PE, Johnson ML, Celniker A, Perlman AJ, Alberti KG \& Thorner MO. A low dose euglycemic infusion of recombinant human insulin-like growth factor I rapidly suppresses fastingenhanced pulsatile growth hormone secretion in humans. J Clin Invest 199391 2453-2462.

41. Berelowitz M, Szabo M, Frohman LA, Firestone S, Chu L \& Hintz RL. Somatomedin-C mediates growth hormone negative feedback by effects on both the hypothalamus and the pituitary. Science 1981212 1279-1281.

42. Sizonenko PC, Clayton PE, Cohen P, Hintz RL, Tanaka T \& Laron Z. Diagnosis and management of growth hormone deficiency in childhood and adolescence. Part 1: diagnosis of growth hormone deficiency. Growth Horm IGF Res 200111 137-165.

43. Loveridge N \& Noble BS. Control of longitudinal growth: the role of nutrition. Eur J Clin Nutr 199448 7584.

44. Karlberg J. On the modelling of human growth. Stat Med 19876 185-192. 
45. Andrade SE, Gurwitz JH, Cernieux J \& Fish LS. Evaluation of a formulary switch from conjugated to esterified estrogens in a managed care setting. Med Care 200038 970-975.

46. Argente J, Barrios V, Pozo J, Munoz MT, Hervas F, Stene M \& Hernandez M. Normative data for insulinlike growth factors (IGFs), IGF-binding proteins, and growth hormone-binding protein in a healthy Spanish pediatric population: age- and sex-related changes. J Clin Endocrinol Metab 199377 1522-1528.

47. Juul A, Bang P, Hertel NT, Main K, Dalgaard P, Jorgensen K, Muller J, Hall K \& Skakkebaek NE. Serum insulin-like growth factor-I in 1030 healthy children, adolescents, and adults: relation to age, sex, stage of puberty, testicular size, and body mass index. J Clin Endocrinol Metab 199478 744-752.

48. Juul A, Dalgaard P, Blum WF, Bang P, Hall K, Michaelsen KF, Muller J \& Skakkebaek NE. Serum levels of insulin-like growth factor (IGF)-binding protein-3 (IGFBP-3) in healthy infants, children, and adolescents: the relation to IGF-I, IGF-II, IGFBP-1, IGFBP-2, age, sex, body mass index, and pubertal maturation. J Clin Endocrinol Metab 199580 2534-2542.

49. Leger J, Oury JF, Noel M, Baron S, Benali K, Blot P \& Czernichow P. Growth factors and intrauterine growth retardation. I. Serum growth hormone, insulin-like growth factor (IGF)-I, IGF-II, and IGF binding protein 3 levels in normally grown and growth-retarded human fetuses during the second half of gestation. Pediatr Res 199640 94-100.

50. Moller N \& Jorgensen JO. Effects of Growth Hormone on Glucose, Lipid and Protein Metabolism in Human Subjects. Endocr Rev 2009.

51. Mekala KC \& Tritos NA. Effects of recombinant human growth hormone therapy in obesity in adults: a meta analysis. J Clin Endocrinol Metab 200994 130-137.

52. Eden S, Bengtsson BA \& Oscarsson J. Effects of growth hormone on body composition and metabolism. Acta Paediatr Scand Suppl 1990367 14-19.

53. Bengtsson BA, Brummer RJ \& Bosaeus I. Growth hormone and body composition. Horm Res 199033 Suppl 4 19-24.

54. Novak LP, Hayles AB \& Cloutier MD. Effect of HGH on body composition of hypopituitary dwarfs. Fourcompartment analysis and composite body density. Mayo Clin Proc 197247 241-246.

55. Bengtsson BA, Brummer RJ, Eden S, Bosaeus I \& Lindstedt G. Body composition in acromegaly: the effect of treatment. Clin Endocrinol (Oxf) 198931 481-490.

56. Dietz J \& Schwartz J. Growth hormone alters lipolysis and hormone-sensitive lipase activity in 3T3-F442A adipocytes. Metabolism 199140 800-806.

57. Ottosson M, Vikman-Adolfsson K, Enerback S, Elander A, Bjorntorp P \& Eden S. Growth hormone inhibits lipoprotein lipase activity in human adipose tissue. J Clin Endocrinol Metab 199580 936-941.

58. Moller N, Jorgensen JO, Schmitz O, Moller J, Christiansen J, Alberti KG \& Orskov H. Effects of a growth hormone pulse on total and forearm substrate fluxes in humans. Am J Physiol 1990258 E86-91.

59. Attallah $H$, Friedlander AL \& Hoffman AR. Visceral obesity, impaired glucose tolerance, metabolic syndrome, and growth hormone therapy. Growth Horm IGF Res 200616 Suppl A S62-67.

60. Buijs MM, Burggraaf J, Langendonk JG, Schoemaker RC, Frolich M, Arndt JW, Cohen AF, Romijn JA, Ackermans MT, Sauerwein HP, Meinders AE \& Pijl H. Hyposomatotropism blunts lipolysis in abdominally obese women. J Clin Endocrinol Metab 200287 3851-3858.

61. Pasarica M, Zachwieja JJ, Dejonge L, Redman S \& Smith SR. Effect of Growth Hormone on Body Composition and Visceral Adiposity in Middle Aged Men with Visceral Obesity. J Clin Endocrinol Metab 2007.

62. Snel YE, Brummer RJ, Doerga ME, Zelissen PM, Bakker CJ, Hendriks MJ \& Koppeschaar HP. Adipose tissue assessed by magnetic resonance imaging in growth hormone-deficient adults: the effect of growth hormone replacement and a comparison with control subjects. Am J Clin Nutr 199561 1290-1294.

63. Bengtsson BA, Brummer RJ, Eden S, Rosen T \& Sjostrom L. Effects of growth hormone on fat mass and fat distribution. Acta Paediatr Suppl 1992383 62-65; discussion 66.

64. Attallah H, Friedlander AL, Nino-Murcia M \& Hoffman AR. Effects of growth hormone and pioglitazone in viscerally obese adults with impaired glucose tolerance: a factorial clinical trial. PLoS Clin Trials 20072 e21.

65. Moller N, Jorgensen JO, Alberti KG, Flyvbjerg A \& Schmitz O. Short-term effects of growth hormone on fuel oxidation and regional substrate metabolism in normal man. J Clin Endocrinol Metab 1990701179 1186.

66. Gravholt CH, Schmitz O, Simonsen L, Bulow J, Christiansen JS \& Moller N. Effects of a physiological GH pulse on interstitial glycerol in abdominal and femoral adipose tissue. Am J Physiol 1999277 E848-854. 
67. Djurhuus CB, Gravholt CH, Nielsen S, Pedersen SB, Moller N \& Schmitz O. Additive effects of cortisol and growth hormone on regional and systemic lipolysis in humans. Am J Physiol Endocrinol Metab 2004286 E488-494.

68. Rabinowitz D, Klassen GA \& Zierler KL. Effect of Human Growth Hormone on Muscle and Adipose Tissue Metabolism in the Forearm of Man. J Clin Invest 196544 51-61.

69. Zierler KL \& Rabinowitz D. Roles of Insulin and Growth Hormone, Based on Studies of Forearm Metabolism in Man. Medicine (Baltimore) 196342 385-402.

70. Ho KY, Veldhuis JD, Johnson ML, Furlanetto R, Evans WS, Alberti KG \& Thorner MO. Fasting enhances growth hormone secretion and amplifies the complex rhythms of growth hormone secretion in man. $J$ Clin Invest 198881 968-975.

71. Cowan FJ, Evans WD \& Gregory JW. Metabolic effects of discontinuing growth hormone treatment. Arch Dis Child 199980 517-523.

72. Wolf RF, Heslin MJ, Newman E, Pearlstone DB, Gonenne A \& Brennan MF. Growth hormone and insulin combine to improve whole-body and skeletal muscle protein kinetics. Surgery 1992112 284-291; discussion 291-282.

73. Bengtsson BA, Brummer RJ, Eden S \& Bosaeus I. Body composition in acromegaly. Clin Endocrinol (Oxf) 198930 121-130.

74. Carrel AL \& Allen DB. Effects of growth hormone on adipose tissue. J Pediatr Endocrinol Metab 200013 Suppl 2 1003-1009.

75. Gerver WJ, De Bruin R, Delemarre v d Waal HA, Aldewereld B, Theunissen P \& Westerterp KR. Effects of discontinuation of growth hormone treatment on body composition and metabolism. Horm Res 200053 215-220.

76. Noordam C, Peer PG, Francois I, De Schepper J, van den Burgt I \& Otten BJ. Long-term GH treatment improves adult height in children with Noonan syndrome with and without mutations in protein tyrosine phosphatase, non-receptor-type 11. Eur J Endocrinol 2008159 203-208.

77. Burman P, Ritzen EM \& Lindgren AC. Endocrine dysfunction in Prader-Willi syndrome: a review with special reference to GH. Endocr Rev 200122 787-799.

78. Cianfarani S, Vaccaro F, Pasquino AM, Marchione SA, Passeri F, Spadoni GL, Bernardini S, Spagnoli A \& Boscherini B. Reduced growth hormone secretion in Turner syndrome: is body weight a key factor? Horm Res 199441 27-32.

79. Shalet SM, Toogood A, Rahim A \& Brennan BM. The diagnosis of growth hormone deficiency in children and adults. Endocr Rev 199819 203-223.

80. Root AW \& Root MJ. Clinical pharmacology of human growth hormone and its secretagogues. Curr Drug Targets Immune Endocr Metabol Disord 20022 27-52.

81. Saggese G, Ranke MB, Saenger P, Rosenfeld RG, Tanaka T, Chaussain JL \& Savage MO. Diagnosis and treatment of growth hormone deficiency in children and adolescents: towards a consensus. Ten years after the Availability of Recombinant Human Growth Hormone Workshop held in Pisa, Italy, 27-28 March 1998. Horm Res 199850 320-340.

82. Carel JC, Coste J, Gendrel C \& Chaussain JL. Pharmacological testing for the diagnosis of growth hormone deficiency. Growth Horm IGF Res 19988 Suppl A 1-8.

83. Svensson J, Mattsson A, Rosen T, Wiren L, Johannsson G, Bengtsson BA \& Koltowska Haggstrom M. Three-years of growth hormone $(\mathrm{GH})$ replacement therapy in GH-deficient adults: effects on quality of life, patient-reported outcomes and healthcare consumption. Growth Horm IGF Res 200414 207-215.

84. Verhelst J, Abs R, Vandeweghe M, Mockel J, Legros JJ, Copinschi G, Mahler C, Velkeniers B, Vanhaelst L, Van Aelst A, De Rijdt D, Stevenaert A \& Beckers A. Two years of replacement therapy in adults with growth hormone deficiency. Clin Endocrinol (Oxf) 199747 485-494.

85. Vance ML \& Mauras N. Growth hormone therapy in adults and children. N Engl J Med 1999341 12061216.

86. Ranke MB, Lindberg A, Chatelain P, Wilton P, Cutfield W, Albertsson-Wikland K \& Price DA. Derivation and validation of a mathematical model for predicting the response to exogenous recombinant human growth hormone $(\mathrm{GH})$ in prepubertal children with idiopathic GH deficiency. KIGS International Board. Kabi Pharmacia International Growth Study. J Clin Endocrinol Metab 199984 1174-1183. 
87. Albertsson-Wikland K, Aronson AS, Gustafsson J, Hagenas L, Ivarsson SA, Jonsson B, Kristrom B, Marcus C, Nilsson KO, Ritzen EM, Tuvemo T, Westphal O \& Aman J. Dose-dependent effect of growth hormone on final height in children with short stature without growth hormone deficiency. J Clin Endocrinol Metab 200893 4342-4350.

88. Franco C, Bengtsson BA \& Johannsson G. The GH/IGF-1 Axis in Obesity: Physiological and Pathological Aspects. Metab Syndr Relat Disord 20064 51-56.

89. Franco C, Brandberg J, Lonn L, Andersson B, Bengtsson BA \& Johannsson G. Growth hormone treatment reduces abdominal visceral fat in postmenopausal women with abdominal obesity: a 12-month placebocontrolled trial. J Clin Endocrinol Metab 200590 1466-1474.

90. Veldhuis JD, Liem AY, South S, Weltman A, Weltman J, Clemmons DA, Abbott R, Mulligan T, Johnson ML, Pincus $S$ \& et al. Differential impact of age, sex steroid hormones, and obesity on basal versus pulsatile growth hormone secretion in men as assessed in an ultrasensitive chemiluminescence assay. $J$ Clin Endocrinol Metab 199580 3209-3222.

91. Marin P, Kvist H, Lindstedt G, Sjostrom L \& Bjorntorp P. Low concentrations of insulin-like growth factor-I in abdominal obesity. Int J Obes Relat Metab Disord 199317 83-89.

92. de Boer H, Blok GJ \& Van der Veen EA. Clinical aspects of growth hormone deficiency in adults. Endocr Rev 199516 63-86.

93. Johannsson G, Marin P, Lonn L, Ottosson M, Stenlof K, Bjorntorp P, Sjostrom L \& Bengtsson BA. Growth hormone treatment of abdominally obese men reduces abdominal fat mass, improves glucose and lipoprotein metabolism, and reduces diastolic blood pressure. J Clin Endocrinol Metab 199782 727-734.

94. Reeds PJ. Dispensable and indispensable amino acids for humans. J Nutr $20001301835 \mathrm{~S}-1840$ S.

95. Crim MC \& Munro HN. Proteins and amino acids. In Modern nutrition in health and disease, pp 3-36. Eds ME Shils, JA Olsen \& M Shike. Philadelphia: Lea \& Febiger, 1994.

96. Waterlow JC. The requirements of adult man for indispensable amino acids. Eur J Clin Nutr $1996 \mathbf{5 0}$ Suppl 1 S151-176; discussion S176-159.

97. Protein and amino acid requirements in human nutrition; Report oa a joint WHO/FAO/UNU Expert Consultation. World health Organisation, 2007.

98. Besset A, Bonardet A, Rondouin G, Descomps B \& Passouant P. Increase in sleep related GH and Prl secretion after chronic arginine aspartate administration in man. Acta Endocrinol (Copenh) 198299 1823.

99. Alba-Roth J, Muller OA, Schopohl J \& von Werder K. Arginine stimulates growth hormone secretion by suppressing endogenous somatostatin secretion. J Clin Endocrinol Metab 198867 1186-1189.

100. Ghigo E, Goffi S, Nicolosi M, Arvat E, Valente F, Mazza E, Ghigo MC \& Camanni F. Growth hormone (GH) responsiveness to combined administration of arginine and GH-releasing hormone does not vary with age in man. J Clin Endocrinol Metab 199071 1481-1485.

101. Ghigo E, Goffi S, Arvat E, Nicolosi M, Procopio M, Bellone J, Imperiale E, Mazza E, Baracchi G \& Camanni F. Pyridostigmine partially restores the $\mathrm{GH}$ responsiveness to $\mathrm{GHRH}$ in normal aging. Acta Endocrinol (Copenh) 1990123 169-173.

102. Cadogan J, Eastell R, Jones N \& Barker ME. Milk intake and bone mineral acquisition in adolescent girls: randomised, controlled intervention trial. Bmj 1997315 1255-1260.

103. Heaney RP, McCarron DA, Dawson-Hughes B, Oparil S, Berga SL, Stern JS, Barr SI \& Rosen CJ. Dietary changes favorably affect bone remodeling in older adults. J Am Diet Assoc 1999 99 1228-1233.

104. Holmes MD, Pollak MN, Willett WC \& Hankinson SE. Dietary correlates of plasma insulin-like growth factor I and insulin-like growth factor binding protein 3 concentrations. Cancer Epidemiol Biomarkers Prev $200211852-861$.

105. Ma J, Giovannucci E, Pollak M, Chan JM, Gaziano JM, Willett W \& Stampfer MJ. Milk intake, circulating levels of insulin-like growth factor-I, and risk of colorectal cancer in men. J Nat/ Cancer Inst 2001931330 1336.

106. Giovannucci E, Pollak M, Liu Y, Platz EA, Majeed N, Rimm EB \& Willett WC. Nutritional predictors of insulin-like growth factor I and their relationships to cancer in men. Cancer Epidemiol Biomarkers Prev $20031284-89$.

107. Hoppe C, Udam TR, Lauritzen L, Molgaard C, Juul A \& Michaelsen KF. Animal protein intake, serum insulin-like growth factor I, and growth in healthy 2.5-y-old Danish children. Am J Clin Nutr 200480447 452 . 


\section{CHAPTER 1}

108. Hoppe C, Molgaard C, Thomsen BL, Juul A \& Michaelsen KF. Protein intake at 9 mo of age is associated with body size but not with body fat in 10-y-old Danish children. Am J Clin Nutr 200479 494-501.

109. Hoppe C, Molgaard C, Juul A \& Michaelsen KF. High intakes of skimmed milk, but not meat, increase serum IGF-I and IGFBP-3 in eight-year-old boys. Eur J Clin Nutr 200458 1211-1216.

110. Rabinowitz D, Merimee TJ, Maffezzoli R \& Burgess JA. Patterns of hormonal release after glucose, protein, and glucose plus protein. Lancet 19662 454-456.

111. Baker HW, Best JB, Burger HG \& Cameron DP. Plasma human growth hormone levels in response to meals: a reappraisal. Aust J Exp Biol Med Sci 197250 715-724.

112. Harber MP, Schenk S, Barkan AL \& Horowitz JF. Effects of dietary carbohydrate restriction with high protein intake on protein metabolism and the somatotropic axis. J Clin Endocrinol Metab 2005905175 5181.

113. Pallotta JA \& Kennedy PJ. Response of plasma insulin and growth hormone to carbohydrate and protein feeding. Metabolism 196817 901-908.

114. Jansz A, Doorenbos H \& Reitsma WD. Effect of food intake on growth-hormone level. Lancet 19631250 251. 


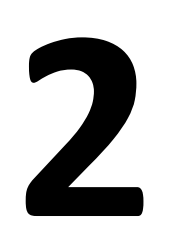

\section{Effects of oral ingestion of amino acids and proteins on the somatotropic axis}

ANNEKE J.A.H. VAN VUGHT, ARIE G. NIEUWENHUIZEN, ROBERT-JAN M. BRUMMER, MARGRIET S. WESTERTERP-PLANTENGA

JOURNAL OF CLINICAL ENDOCRINOLOGY AND METABOLISM 2008;93(2):584-590 


\section{ABSTRACT}

Context: Growth hormone $(\mathrm{GH})$ is an important regulator of growth and body composition. It has been shown that $\mathrm{GH}$ release can be promoted by intravenous as well as oral administration of various amino acids (AA), especially arginine and lysine (ARG+LYS), that are ample present in soy protein. The effects of dietary protein on GH secretion, however, are less well described.

Objective/design: In an experiment we compared the effects of oral ingestion of a mixture reflecting the amino acid composition of soy protein (AA), with oral ingestion of arginine + lysine, on $\mathrm{GH}$-secretion in eight healthy women (BMI=19$25 \mathrm{~kg} / \mathrm{m}^{2}$; 18-24years). In a second experiment, we compared oral ingestion of hydrolysed soy protein and complete soy protein with the AA-mixture on GH secretion in eight healthy women (BMI $=19-26 \mathrm{~kg} / \mathrm{m}^{2} ; 19-36$ years).

Both experiments were performed in a randomized single blind cross-over design. Serum GH, insulin glucose and plasma AA were determined every 20 minutes, during $3 \mathrm{~h}$ in the first experiment and during $5 \mathrm{~h}$ in the second experiment.

Results: Peak values of $\mathrm{GH}$ were higher after ingestion of the AA-mixture compared with ingestion of ARG+LYS ( $p<0.05)$. GH-responses, as determined by area under the curve $(A \cup C)$, did not significantly differ after ingestion of the complete soy protein, hydrolysed soy protein or AA-mixture, but were all higher than after placebo $(p<0.05)$.

Insulin-responses (AUC) were higher after ingestion of hydrolysed soy protein, complete soy protein and AA-mixture, compared with placebo $(p<0.05)$. Glucose concentrations were unaffected.

Conclusion: Ingestion of soy protein, either hydrolysed or intact, as well as amino acids reflecting, soy protein stimulates $\mathrm{GH}$ release to a similar extent. 


\section{INTRODUCTION}

Growth hormone $(\mathrm{GH})$, a hormone originating from the anterior pituitary gland, is an important regulator of growth and body composition ${ }^{1}$. GH exerts its growth promoting effect (typically of fat-free mass) through stimulation of the secretion of Insulin-Like Growth Factor I (IGF-I) from the target cells ${ }^{1}$. Disorders as obesity, sarcopenia and growth retardation in children are characterized by low $\mathrm{GH}$ concentrations $^{1-4}$.

It has been shown by many authors that GH secretion can be promoted by intravenous administration of various amino acids, including arginine, methionine, phenylalanine, lysine and histidine ${ }^{5,6}$. Leucine and valine seem less potent, while isoleucine does not seem to affect plasma GH concentrations ${ }^{5,6}$. In particular, the stimulatory effect of intravenous arginine on $\mathrm{GH}$ is clinically used as a method to assess the responsiveness of the GH secretory system, e.g., when GH deficiency is suspected ${ }^{7}$.

The stimulatory effect of amino acids on $\mathrm{GH}$ secretion is also present when amino acids are administered orally. Thus, ingestion of a dosage of $24 \mathrm{~g}$ of a mixture of essential amino acids increased plasma GH concentrations with 2,1 fold in comparison with basal values ${ }^{8}$. It is not clear whether all amino acids contribute equally to this phenomenon. Glutamine, arginine, glutamic acid and arginine plus lysine, have been shown to stimulate the GH response in several studies ${ }^{5,9}$. After oral ingestion of glutamine or arginine, plasma GH-concentrations increased $2-4,5$ fold higher in comparison with time controls ${ }^{9,10}$, while a combination of arginine and lysine increased plasma $\mathrm{GH}$-concentration 3-8 fold ${ }^{11,}{ }^{12}$. In contrast, oral ingestion of aspartic acid or cysteine did not affect $\mathrm{GH}$ concentrations ${ }^{5}$.

Effects of amino acids on $\mathrm{GH}$ secretion, as mentioned above, may suggest a role of dietary protein in the regulation of plasma GH concentrations. However, only a limited number of studies focused on the effects of dietary proteins and diet composition on GH secretion. It has been shown that in children, dairy (but not meat) consumption is positively associated with growth and plasma concentrations of IGF- $\mathrm{I}^{13}$. Also, the $\mathrm{GH}$ responses to an arginine stimulus were lower during a high carbohydrate diet, than during a high fat or a high protein diet ${ }^{14}$.

Because the effects of dietary protein on $\mathrm{GH}$ secretion are less well documented, this study aims to investigate the effects of dietary soy protein ingestion, containing approximately equal amounts of arginine and lysine, on plasma GH concentrations. Amino acid mixtures are expected to be absorbed more rapidly then protein hydrolysates, which are expected to be absorbed more rapidly then intact proteins. This may result in different peak values of amino acids in the plasma, which may affect $\mathrm{GH}$ release. 


\section{METHODS \& MATERIALS}

Two series of experiments were performed to investigate the effects of dietary protein ingestion on plasma $\mathrm{GH}$ concentration. In the first experiment, the effects of ingestion of an amino acid mixture reflecting soy protein (AA) were compared with the effects of arginine and lysine (ARG+LYS). In the second series of experiments, the effects of oral ingestion of proteins (complete and hydrolysed) were compared with the effects of the AA-mixture on GH secretion.

\section{Subjects}

Subjects were recruited via advertisements at the university. In the first experiment as well as in the second experiment, eight healthy young females (experiment 1 : age $21 \pm 2.6$ years, BMI $22.5 \pm 2.5 \mathrm{~kg} / \mathrm{m}^{2}$, experiment 2 : age $24 \pm 5.5$ years, $\mathrm{BMI}$ $22.7 \pm 1.9 \mathrm{~kg} / \mathrm{m}^{2}$ ) participated. Each subject participated once in this study. Subjects were in good health, non-smoker, using contraceptives, free of any other medication and spent no more than three hours a week on sport activities. Women came to the university in the same phase of their 'menstrual cycle'. The Medical Ethics Committee of Maastricht University approved the study protocol and all subjects gave their written informed consent before participating in the study.

\section{Experimental design}

A randomized cross-over study design was applied in both series of experiments. In the first experiment, subjects reported to the laboratory for consumption of 2 different testdrinks and in the second experiment for consumption of 4 different testdrinks, all testdrinks at separate test days. Each time, subjects arrived at the laboratory in a fasted state, in the morning. They were instructed to fast from 10 $\mathrm{pm}$ the night prior to the test day. A permanent cannula was inserted into a dorsal vein of the hand, which was placed in a thermoregulated $\left(60^{\circ} \mathrm{C}\right)$ box for arterialized venous blood sampling ${ }^{15}$. Blood sampling began $60 \mathrm{~min}$ after placement of the cannula. Blood was sampled every $20 \mathrm{~min}$ for the next $3 \mathrm{~h}$ in the first experiment and for the next $5 \mathrm{~h}$ in the second experiment. During blood sampling, subjects remained awake and fasted and were allowed to drink water ad libitum. Immediately after obtaining the first blood sample, subjects received a testdrink. The testdrinks are described in Table 1. In the first experiment, subjects received the AA-testdrink and the ARG+LYS testdrink. In the second experiment, subjects received a drink containing a complete soy protein testdrink, a hydrolysed soy protein testdrink, an AA-testdrink (reflecting soy protein) and a placebo-testdrink. The AA in the AA-testdrinks were obtained from Bufa BV (Uitgeest, the Netherlands). The sugarfree syrup (Diaran, Cereal) added to the AA-drinks contained no proteins 
and fat and a negligible amount of carbohydrates. The syrup was added to increase the taste of the testdrink. The protein-testdrinks were produced by NIZO (Nederlands Instituut Zuivel Onderzoek, Ede, the Netherlands).

Table 1: Composition of the testdrinks in experiment 1 and 2, based on a subject of $70 \mathrm{~kg}$.

\begin{tabular}{lcc|cccc}
\hline & \multicolumn{2}{c|}{ Experiment 1 } & \multicolumn{3}{c}{ Experiment 2 } \\
& AA & ARG+LYS & $\begin{array}{c}\text { Hydrolysed } \\
\text { soy protein }\end{array}$ & $\begin{array}{c}\text { Complete soy } \\
\text { protein }\end{array}$ & AA & Placebo \\
\hline Volume (ml) & 250 & 250 & 467 & 467 & 500 & 500 \\
Cystein(g) & 0.22 & - & 0.46 & 0.46 & 0.44 & - \\
Methionine(g) & 0.23 & - & 0.46 & 0.46 & 0.46 & - \\
Aspartic acid(g) & 2.06 & - & 4.00 & 4.28 & 4.12 & - \\
Threonine(g) & 0.67 & - & 1.30 & 1.40 & 1.36 & - \\
Serine(g) & 0.91 & - & 1.76 & 1.93 & 1.82 & - \\
Glutamic acid(g) & 3.38 & - & 6.34 & 7.04 & 6.76 & - \\
Proline(g) & 0.89 & - & 1.76 & 1.89 & 1.79 & - \\
Glycine(g) & 0.73 & - & 1.42 & 1.55 & 1.47 & - \\
Alanine(g) & 0.75 & - & 1.46 & 1.60 & 1.51 & - \\
Valine(g) & 0.88 & - & 1.72 & 1.84 & 1.76 & - \\
Isoleucine(g) & 0.92 & - & 1.68 & 1.80 & 1.84 & - \\
Leucine(g) & 1.49 & - & 2.81 & 3.02 & 2.98 & - \\
Tyrosine(g) & 0.71 & - & 1.26 & 1.39 & 1.42 & - \\
Phenylalanine(g) & 0.97 & - & 1.76 & 1.93 & 1.94 & - \\
Histidine(g) & 0.49 & - & 0.88 & 0.96 & 0.98 & - \\
Lysine(g) & 1.13 & 1.13 & 2.14 & 2.34 & 2.27 & - \\
Arginine(g) & 1.43 & 1.43 & 2.60 & 2.81 & 2.86 & - \\
Tryptophan (g) & 0.24 & - & 0.46 & 0,50 & 0.47 & - \\
Sugar free syrup (ml) & 20 & 20 & - & - & 40 & 40 \\
\hline & & & & & & \\
\hline
\end{tabular}

\section{Blood analysis}

In both experiments, arterialized venous blood was collected in cloth tubes (Becton Dickinson Vacutainer system; Becton Dickinson, Franklin Lakes, NJ) and in the second experiment, arterialized venous blood was also divided into cloth tubes and into heparinized tubes (Becton Dickinson Vacutainer system; Becton Dickinson, Franklin Lakes, NJ). Blood in the clot tube (containing 'Silica Clot Activator') was allowed to clot for 30 minutes and was centrifuged at $3000 \mathrm{rpm}, 4^{\circ} \mathrm{C}$ for $10 \mathrm{~min}$ to obtain serum. Serum in the first experiment was collected for determination of $\mathrm{GH}$ and in the second experiment for determination of $\mathrm{GH}$, insulin, glucose and urea concentrations. Blood in heparinized tubes was kept on ice to minimize enzymatic reactions. Amino acid analyses were performed in plasma, which was obtained by centrifugation at $4^{\circ} \mathrm{C}$ for $10 \mathrm{~min}$ at $3000 x g$. Subsequently $250 \mu \mathrm{L}$ plasma was deproteinized with $20 \mathrm{mg}$ dry sulfosalisylic acid for analysis of plasma amino acids concentrations and enrichment. Each aliquot of serum and plasma was frozen immediately in liquid nitrogen and stored at $-80^{\circ} \mathrm{C}$, until analysis. All samples from one subjects were run in the same assay.

The hGH-concentrations were measured by using an ultrasensitive hGH chemiluminescence immunoassay (Beckman Coulter, Harbor Blvd. Fullerton, U.S.A.). The 
intra- and inter-assay coefficients of variation were $1.4-2.1$ and $6.8-8.6 \%$ respectively, at GH concentrations of 3.7-14.2 and 3.1-7.3 $\mu \mathrm{g} / \mathrm{l}$, respectively.

Insulin concentrations were measured by an electrochemiluminescence immunoassay (ELICA) (Roche Diagnostica, Hoffman-La Roche, Basel, Switzerland). Glucose concentrations were measured by using enzymatic assay (G6-PDH) (Roche Diagnostica, Hoffman-La Roche, Basel, Switzerland). Amino acid concentrations were measured by using a HPLC system (Pharmacia, Woerden, The Netherlands). Urea concentrations were measured spectrophotometrically on a COBAS Mira S (Roche Diagnostica, Hoffman-La Roche, Basel, Switzerland).

\section{Statistics}

All data are expressed as mean \pm SEM. Statistical significance was set at $p<0.05$. Statview SE+Graphics (1988;Abacus Concepts, Berkely, CA, USA) was used for the analysis. In the first experiment, growth hormone responses were calculated as peak values. In the second experiment, growth hormone, insulin, glucose, urea and amino acid responses were calculated as area under the curve (AUC), as peak values and as time to peak values. Statistical analyses of the data were performed using repeated measures analysis of variance (ANOVA), correcting for multiple analyses. Post hoc, the Scheffe F-test was used to locate possible significant differences. 


\section{RESULTS}

In the first series of experiments, GH-responses reached higher peak values after ingestion of the AA-mixture $(4.9 \mu \mathrm{g} / \mathrm{L} \pm 1.2)$ than after ingestion of the arginine + lysine testdrink $(2.2 \mu \mathrm{g} / \mathrm{L} \pm 0.7)(\mathrm{p}<0.05)$. In the second series of experiments, $\mathrm{GH}$ responses, as determined by area under the curve (AUC) and peak values were higher after ingestion of hydrolysed soy protein, complete soy protein and the AAmixture, compared with ingestion of the placebo testdrink $(p<0.05)$. No differences between GH-responses (AUC and peak values) were found after ingestion of hydrolysed soy protein, complete soy protein and the AA-mixture (Figure 1, Table 2).

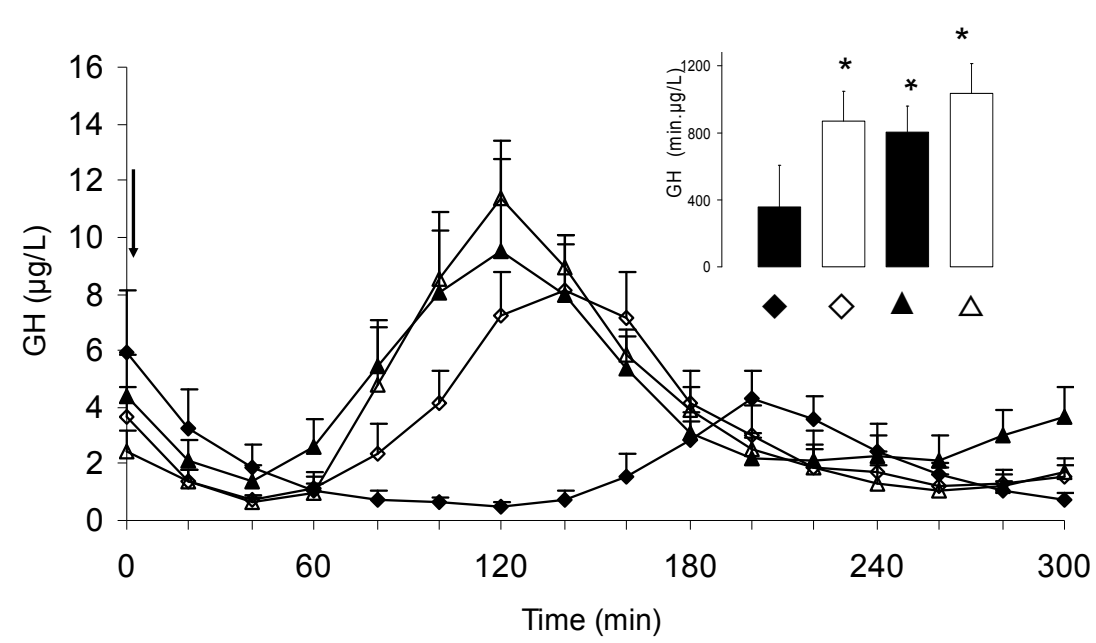

Figure 1: Growth hormone concentrations after ingestion of a placebo-testdrink $(\diamond), \mathrm{AA}$-testdrink $(\diamond)$, hydrolysed soy protein testdrink $(\boldsymbol{\Delta})$, and complete soy protein-testdrink $(\Delta)(N=8)$. Data are presented as means $\left( \pm\right.$ SEM). $\downarrow=$ ingestion of testdrink. ${ }^{*}=p<0.05$ compared with placebo.

The insulin-concentrations, as determined by area under the curve (AUC) and peak values, were higher after ingestion of hydrolysed soy protein, complete soy protein and the AA-mixture, compared with ingestion of the placebo $(p<0.05)$. Ingestion of complete soy protein, hydrolysed soy protein or the AA-mixture did not affect insulin responses (AUC and peak values) (Table 2, Figure 2).

The glucose-response (AUC) did not differ between each of the test testdrinks (Table 2). 


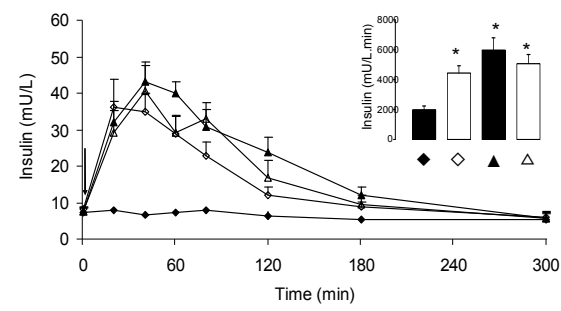

Figure 2: Insulin concentrations after ingestion of a placebo-testdrink $(\diamond)$, AA-testdrink $(\diamond)$, hydrolysed soy protein testdrink $(\boldsymbol{\Delta})$ and complete soy protein-testdrink $(\Delta)(\mathrm{N}=8)$. Data are presented as means ( \pm SEM). $\downarrow=$ ingestion of testdrink. * $=$ $p<0.05$ compared with placebo.

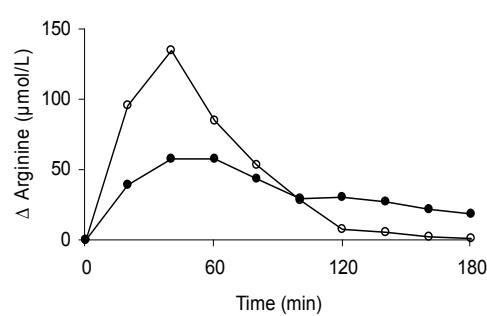

Figure 3: Arginine concentrations after ingestion of the Arg+Lys testdrink and AA testdrink $(\mathrm{N}=8)$. $-\bullet=A r g+$ Lys testdrink, $-0=A A$ testdrink

The arginine-concentration was higher after ingestion of the AA-mixture, compared with the arginine + lysine testdrink which was higher compared with the placebo $(p<0.05)$ (Figure 3). No differences were found in total amino acid peakconcentrations after ingestion of the protein and the AA-testdrink. Glutamic acid, aspartic acid and tyrosine, however, showed a higher peak after ingestion of the hydrolysed and complete soy protein testdrinks compared with the concentrations obtained after ingestion of the AA-testdrink $(p<0.05)$. Valine, phenylalanine and leucine peaks were lower after ingestion of the hydrolysed and complete soy protein testdrinks in comparison with the AA-testdrink $(p<0.05)$. In contrast with the total amino acid peak, total amino acids (AUC) in response to the different testdrinks was higher after ingestion of the hydrolysed and complete soy protein testdrink, compared with the AA-testdrink $(p<0.05)$. The difference in total amino acid concentrations (AUC) between the hydrolysed and complete soy protein testdrink in comparison with the AA-testdrink was also reflected in aspartic acid, glutamic acid, citruline, arginine, tyrosine, methionine, isoleucine and leucine responses $(p<0.05)$. Total amino acids $(A \cup C)$ and each separate amino acid (except for taurine and ornithine) were higher after ingestion of the hydrolysed soy protein testdrink, complete soy protein testdrink and AA-testdrink in comparison with the placebo-testdrink $(p<0.05)$. Time to peak (TTP) was later after ingestion of hydrolysed and complete soy protein testdrink ( $85 \mathrm{~min}$ ) than after ingestion of the AAtestdrink ( $45 \mathrm{~min}$ ) $(\mathrm{p}<0.05)$. This difference in TTP was also reflected by the TTP in serine, histidine, citruline, tyrosine, valine, methionine, isoleucine, phenylalanine, tryptophan and leucine $(p<0.05)$. Table 2 shows an overview of the differences in $A A-c o n c e n t r a t i o n$ as measured by AUC, peak-values and time to peak, between the protein-testdrinks, AA-testdrink and placebo testdrink. Figure 4 shows each separate amino acid over time after ingestion of the testdrinks. 
Urea-concentrations, as determined by area under the curve (AUC) did not differ between ingestion of hydrolysed soy protein, complete soy protein or the AAmixture, but were higher than after ingestion of placebo $(p<0.05)$ (Table 2$)$.
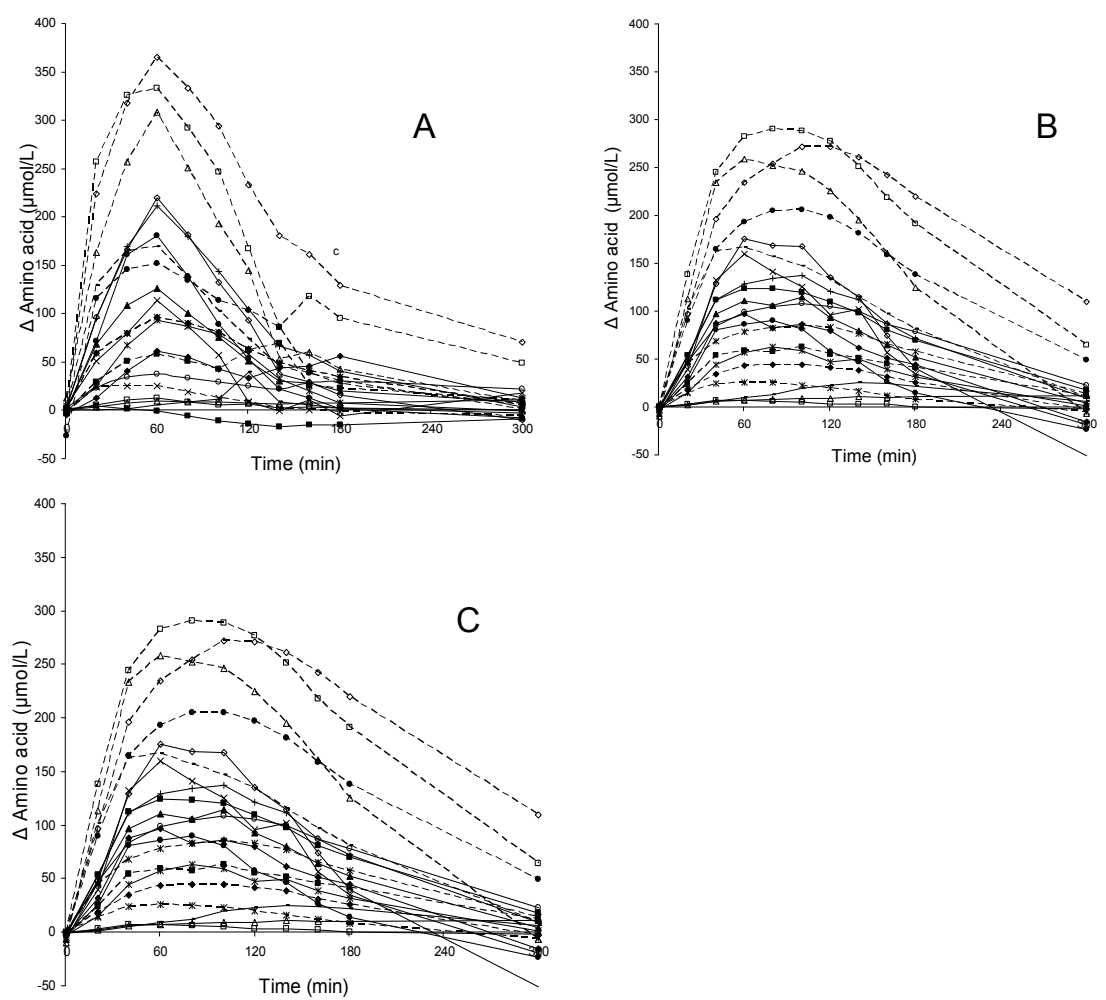

Figure 4: Amino acid concentrations after ingestion of the AA-testdrink (a), hydrolysed soy protein testdrink (b), and complete soy protein-testdrink (c) ( $N=8)$.

$-\bullet$ glutamine, $-\mathbf{\square}=$ aspartic acid, $-\mathbf{\Delta}$ = serine, $-\times$ = glutamic acid,

$-*$ = histidine, $-\mathbf{O}=$ glycine,$-\mid=$ threonine, $-\boldsymbol{-}=$ citruline,$-\diamond=$ alanine,

$-\square$ = taurine, $-\triangle=\mathrm{aAB},-\bigcirc=$ tyrosine, $--\times=$ methionine, $--*=$ phenylanaline,

$---=$ tryptophan, $--\boldsymbol{\square}=$ ornithine, $--\boldsymbol{\Delta}$ = arginine, $--\boldsymbol{O}=$ isoleucine, $--\diamond=$ valine,

$--\square$ = leucine, $--\Delta=$ lysine 
Table 2: Blood parameters after ingestion of a placebo-testdrink, AA-testdrink, hydrolysed soy protein testdrink and complete soy protein testdrink $(n=8)$, expressed as AUC (a), peak-values (b) and time to peak, TTP (c).

\begin{tabular}{|c|c|c|c|c|c|c|c|c|c|c|c|c|}
\hline \multirow{3}{*}{$\begin{array}{l}\mathrm{a} \\
\mathrm{GH}(\min . \mu \mathrm{g} / \mathrm{L})\end{array}$} & \multicolumn{12}{|c|}{ AUC } \\
\hline & \multicolumn{3}{|c|}{ Placebo } & \multicolumn{3}{|c|}{ AA-mix } & \multicolumn{3}{|c|}{ Hydrolysed } & \multicolumn{3}{|c|}{ Complete } \\
\hline & 357 & \pm & 94 & 870 & \pm & $176^{\mathrm{a}}$ & 804 & \pm & $154^{2}$ & 1035 & \pm & $179^{a}$ \\
\hline Insulin (min.mU/L) & 1985 & \pm & 268 & 4452 & \pm & $649^{\mathrm{a}}$ & 5988 & \pm & $822^{\mathrm{a}}$ & 5087 & \pm & $605^{\mathrm{a}}$ \\
\hline Glucose (min.mmol/L) & 874 & \pm & 68 & 1044 & \pm & 35 & 996 & \pm & 39 & 998 & \pm & 35 \\
\hline Urea (min.mmol/L) & 62 & \pm & 42 & 307 & \pm & $60^{\mathrm{a}}$ & 426 & \pm & $78^{\mathrm{a}}$ & 366 & \pm & $53^{a}$ \\
\hline Total AA (min.mol/L) & -23.0 & \pm & 16.4 & 27.3 & \pm & $4.7^{\mathrm{a}}$ & 43.0 & \pm & $29.0^{a . b}$ & 40.8 & \pm & $22.9^{a \cdot b}$ \\
\hline Glutamine & -3.9 & \pm & 1.6 & 11.4 & \pm & $4.0^{\mathrm{a}}$ & 13.7 & \pm & $1.5^{\mathrm{a}}$ & 12.4 & \pm & $2.1^{\mathrm{a}}$ \\
\hline Aspartic acid & -1.3 & \pm & 0.8 & 2.7 & \pm & 0.4 & 22.4 & \pm & $1.6^{\text {a.b }}$ & 22.5 & \pm & $1.0^{a . b}$ \\
\hline Serine & -0.1 & \pm & 0.9 & 13.7 & \pm & $3.0^{\mathrm{a}}$ & 18.2 & \pm & $2.5^{\mathrm{a}}$ & 19.3 & \pm & $1.1^{\mathrm{a}}$ \\
\hline Glutamic acid & -2.8 & \pm & 3.2 & 8.8 & \pm & 3.5 & 18.3 & \pm & $3.5^{\mathrm{a}}$ & 20.7 & \pm & $3.2^{\mathrm{a}}$ \\
\hline Histidine & -0.2 & \pm & 1.0 & 9.7 & \pm & $2.8^{\mathrm{a}}$ & 9.8 & \pm & $2.0^{\mathrm{a}}$ & 11.3 & \pm & $1.3^{\mathrm{a}}$ \\
\hline Glysine & -0.2 & \pm & 2.6 & 14.2 & \pm & $2.5^{\mathrm{a}}$ & 9.5 & \pm & $2.5^{\mathrm{a}}$ & 11.7 & \pm & $1.7^{\mathrm{a}}$ \\
\hline Threonine & -2.9 & \pm & 1.8 & 23.5 & \pm & $2.5^{\mathrm{a}}$ & 23.2 & \pm & $2.6^{\mathrm{a}}$ & 20.8 & \pm & $2.3^{\mathrm{a}}$ \\
\hline Citruline & -0.4 & \pm & 0.2 & 1.6 & \pm & $0.5^{\mathrm{a}}$ & 4.3 & \pm & $0.5^{a . b}$ & 4.1 & \pm & $0.4^{a . b}$ \\
\hline ARG & 0.6 & \pm & 0.9 & 19.5 & \pm & $2.5^{\mathrm{a}}$ & 27.9 & \pm & $3.2^{a . b}$ & 26.7 & \pm & $3.4^{a}$ \\
\hline Alanine & -16.6 & \pm & 5.1 & 19.6 & \pm & $3.4^{\mathrm{a}}$ & 20.0 & \pm & $6.4^{\mathrm{a}}$ & 20.7 & \pm & $3.4^{\mathrm{a}}$ \\
\hline Taurine & 0.2 & \pm & 0.2 & 1.3 & \pm & $0.4^{\mathrm{a}}$ & 0.6 & \pm & 0.2 & 1.2 & \pm & 0.3 \\
\hline аAB & 0.9 & \pm & 0.2 & 2.5 & \pm & $0.3^{\mathrm{a}}$ & 2.7 & \pm & $0.4^{\mathrm{a}}$ & 2.7 & \pm & $0.3^{\mathrm{a}}$ \\
\hline Tyrosine & -1.3 & \pm & 0.8 & 8.1 & \pm & $1.5^{\mathrm{a}}$ & 21.5 & \pm & $1.5^{\mathrm{a} . \mathrm{b}}$ & 18.6 & \pm & $1.1^{a . b}$ \\
\hline Valine & 0.4 & \pm & 0.9 & 55.4 & \pm & $3.9^{\mathrm{a}}$ & 58.5 & \pm & $2.4^{\mathrm{a}}$ & 48.2 & \pm & $6.9^{\mathrm{a}}$ \\
\hline Methionine & -0.6 & \pm & 0.1 & 1.8 & \pm & $0.7^{\mathrm{a}}$ & 3.4 & \pm & $0.4^{a . b}$ & 3.1 & \pm & $0.2^{\mathrm{a}}$ \\
\hline Isoleucine & 1.6 & \pm & 0.6 & 19.9 & \pm & $7.6^{\mathrm{a}}$ & 40.6 & \pm & $0.2^{\mathrm{a} . \mathrm{b}}$ & 35.2 & \pm & $1.9^{a . b}$ \\
\hline Phenylalanine & 0.0 & \pm & 0.4 & 13.9 & \pm & $3.0^{\mathrm{a}}$ & 16.5 & \pm & $1.4^{\mathrm{a}}$ & 14.1 & \pm & $1.0^{\mathrm{a}}$ \\
\hline Tryptophan & -1.3 & \pm & 0.8 & 5.3 & \pm & $1.6^{\mathrm{a}}$ & 7.6 & \pm & $1.0^{\mathrm{a}}$ & 6.6 & \pm & $0.6^{a}$ \\
\hline Leucine & 3.6 & \pm & 1.1 & 46.1 & \pm & $3.3^{\mathrm{a}}$ & 57.1 & \pm & $3.1^{a . b}$ & 49.7 & \pm & $2.7^{a . b}$ \\
\hline Ornitine & -6.5 & \pm & 6.6 & 10.0 & \pm & 1.9 & 28.0 & \pm & 17.8 & 10.9 & \pm & 0.9 \\
\hline LYS & -2.4 & \pm & 3.9 & 33.2 & \pm & $2.7^{\mathrm{a}}$ & 42.1 & \pm & $4.1^{\mathrm{a}}$ & 42.4 & \pm & $3.3^{\mathrm{a}}$ \\
\hline
\end{tabular}

\begin{tabular}{|c|c|c|c|c|c|c|c|c|c|c|c|c|}
\hline \multirow{3}{*}{$\begin{array}{l}\mathrm{b} \\
\mathrm{GH}(\mu \mathrm{g} / \mathrm{L})\end{array}$} & \multicolumn{12}{|c|}{ Peak } \\
\hline & \multicolumn{3}{|c|}{ Placebo } & \multicolumn{3}{|c|}{ AA-mix } & \multicolumn{3}{|c|}{ Hydrolysed } & \multicolumn{3}{|c|}{ Complete } \\
\hline & 4 & \pm & 3 & 12 & \pm & $5^{a}$ & 9 & \pm & $3^{a}$ & 13 & \pm & $4^{a}$ \\
\hline Insulin (mU/L) & & . & & 40 & \pm & 7 & 47 & \pm & 7 & 44 & \pm & 5 \\
\hline Glucose (mmol/L) & & . & & & . & & & . & & & . & \\
\hline Urea (mmol/L) & & . & & & . & & & . & & & . & \\
\hline Total AA $(\mu \mathrm{mol} / \mathrm{L})$ & & . & & 4592 & \pm & 229 & 4865 & \pm & 200 & 4782 & \pm & 221 \\
\hline Glutamine & & . & & 171 & \pm & 24 & 232 & \pm & $19^{b}$ & 230 & \pm & $18^{\mathrm{b}}$ \\
\hline Aspartic acid & & . & & 58 & \pm & 4 & 182 & \pm & $9^{\mathrm{b}}$ & 203 & \pm & $11^{\mathrm{b}}$ \\
\hline Serine & & . & & 247 & \pm & 26 & 255 & \pm & 113 & 251 & \pm & 13 \\
\hline Glutamic acid & & . & & 540 & \pm & 17 & 597 & \pm & 32 & 577 & \pm & 27 \\
\hline Histidine & & . & & 190 & \pm & 21 & 161 & \pm & 8 & 160 & \pm & 9 \\
\hline Glysine & & . & & 338 & \pm & 28 & 292 & \pm & 16 & 289 & \pm & 16 \\
\hline Threonine & & . & & 357 & \pm & 21 & 294 & \pm & 13 & 313 & \pm & 22 \\
\hline Citruline & & . & & 66 & \pm & 22 & 49 & \pm & 3 & 48 & \pm & 3 \\
\hline ARG & & . & & 234 & \pm & 29 & 244 & \pm & 35 & 237 & \pm & 32 \\
\hline Alanine & & . & & 455 & \pm & 48 & 469 & \pm & 23 & 471 & \pm & 20 \\
\hline Taurine & & . & & 51 & \pm & 9 & 38 & \pm & 2 & 44 & \pm & 2 \\
\hline $\mathrm{aAB}$ & & . & & 27 & \pm & 2 & 31 & \pm & 3 & 26 & \pm & 3 \\
\hline Tyrosine & & . & & 96 & \pm & 12 & 160 & \pm & $10^{b}$ & 147 & \pm & $6^{\mathrm{b}}$ \\
\hline Valine & & . & & 563 & \pm & 28 & 451 & \pm & $17^{\mathrm{b}}$ & 418 & \pm & $13^{\mathrm{b}}$ \\
\hline Methionine & & . & & 50 & \pm & 4 & 49 & \pm & 4 & 46 & \pm & 2 \\
\hline Isoleucine & & . & & 277 & \pm & 30 & 276 & \pm & 14 & 258 & \pm & 11 \\
\hline Phenylalanine & & . & & 153 & \pm & 12 & 139 & \pm & 8 & 127 & \pm & $5^{b}$ \\
\hline Tryptophan & & . & & 114 & \pm & 26 & 98 & \pm & 4 & 97 & \pm & 4 \\
\hline Leucine & & . & & 445 & \pm & 23 & 407 & \pm & 20 & 384 & \pm & $16^{\mathrm{b}}$ \\
\hline Ornitine & & . & & 138 & \pm & 34 & 109 & \pm & 8 & 97 & \pm & 8 \\
\hline LYS & & & & 459 & \pm & 35 & 437 & \pm & 27 & 442 & \pm & 40 \\
\hline
\end{tabular}




\begin{tabular}{|c|c|c|c|c|c|c|c|c|c|c|c|c|}
\hline \multirow{3}{*}{$\begin{array}{l}\mathrm{c} \\
\mathrm{GH}(\mathrm{min})\end{array}$} & \multicolumn{12}{|c|}{ TTP } \\
\hline & \multicolumn{3}{|c|}{ Placebo } & \multicolumn{3}{|c|}{ AA-mix } & \multicolumn{3}{|c|}{ Hydrolysed } & \multicolumn{3}{|c|}{ Complete } \\
\hline & 195 & \pm & 8 & 120 & \pm & $18^{\mathrm{a}}$ & 130 & \pm & $9^{\mathrm{a}}$ & 113 & \pm & $7^{\mathrm{a}}$ \\
\hline Insulin (min) & & . & & 33 & \pm & 7 & 40 & \pm & 6 & 45 & \pm & 7 \\
\hline Glucose (min) & & . & & & . & & & . & & & . & \\
\hline Urea (min) & & . & & & . & & & . & & & . & \\
\hline Total AA (min) & & . & & 45 & \pm & 4 & 88 & \pm & $10^{\mathrm{b}}$ & 83 & \pm & $8^{\mathrm{b}}$ \\
\hline Glutamine & & . & & 75 & \pm & 9 & 83 & \pm & 11 & 70 & \pm & 11 \\
\hline Aspartic acid & & . & & 63 & \pm & 37 & 75 & \pm & 5 & 88 & \pm & 11 \\
\hline Serine & & . & & 45 & \pm & 4 & 78 & \pm & $6^{\mathrm{b}}$ & 78 & \pm & $9^{b}$ \\
\hline Glutamic acid & & . & & 55 & \pm & 7 & 70 & \pm & 6 & 68 & \pm & 6 \\
\hline Histidine & & . & & 55 & \pm & 5 & 95 & \pm & $14^{\mathrm{b}}$ & 88 & \pm & $7^{\mathrm{b}}$ \\
\hline Glysine & & . & & 58 & \pm & 5 & 75 & \pm & 7 & 75 & \pm & 7 \\
\hline Threonine & & . & & 63 & \pm & 9 & 198 & \pm & 11 & 85 & \pm & 9 \\
\hline Citruline & & . & & 100 & \pm & 7 & 135 & \pm & $7^{\mathrm{b}}$ & 125 & \pm & 7 \\
\hline ARG & & . & & 55 & \pm & 5 & 63 & \pm & 9 & 78 & \pm & 9 \\
\hline Alanine & & . & & 65 & \pm & 4 & 80 & \pm & 7 & 70 & \pm & 6 \\
\hline Taurine & & . & & 65 & \pm & 11 & 48 & \pm & 6 & 60 & $\mathrm{~b}$ & 7 \\
\hline $\mathrm{aAB}$ & & . & & 83 & \pm & 20 & 135 & \pm & 13 & 110 & \pm & 17 \\
\hline Tyrosine & & . & & 53 & \pm & 7 & 105 & \pm & $8^{\mathrm{b}}$ & 95 & \pm & $8^{\mathrm{b}}$ \\
\hline Valine & & . & & 55 & \pm & 10 & 115 & \pm & $8^{\mathrm{b}}$ & 103 & \pm & $6^{\mathrm{b}}$ \\
\hline Methionine & & . & & 33 & \pm & 6 & 78 & \pm & $13^{b}$ & 58 & \pm & 8 \\
\hline Isoleucine & & . & & 40 & \pm & 4 & 98 & \pm & $9^{\mathrm{b}}$ & 88 & \pm & $8^{\mathrm{b}}$ \\
\hline Phenylalanine & & . & & 40 & \pm & 4 & 110 & \pm & $7^{\mathrm{b}}$ & 90 & \pm & $11^{\mathrm{b}}$ \\
\hline Tryptophan & & . & & 48 & \pm & 6 & 85 & \pm & $10^{\mathrm{b}}$ & 88 & \pm & $7^{\mathrm{b}}$ \\
\hline Leucine & & . & & 43 & \pm & 5 & 100 & \pm & $8^{\mathrm{b}}$ & 93 & \pm & $11^{\mathrm{b}}$ \\
\hline Ornitine & & . & & 48 & \pm & 4 & 80 & \pm & 13 & 78 & \pm & 12 \\
\hline LYS & & . & & 53 & \pm & 8 & 85 & \pm & 13 & 83 & \pm & 13 \\
\hline
\end{tabular}

Data are presented as means ( \pm SEM).

${ }^{a} \mathrm{p}<0.05$ compared with the placebo-testdrink (repeated measures ANOVA).

${ }^{b} \mathrm{p}<0.05$ compared with the AA-testdrink (repeated measures ANOVA).

\section{DISCUSSION}

Oral administration of soy protein appeared to stimulate $\mathrm{GH}$ secretion. This effect was preserved when soy protein was ingested as either hydrolysed soy protein or as free amino acids. These results suggested that the potency to stimulated GHsecretion, was not influenced by the rate of amino acid absorption.

A 2.3 fold increase in $\mathrm{GH}$ concentrations was found after oral ingestion of a testdrink with approximately 1.2 gram arginine and 1.2 gram lysine in comparison with basal values. This finding confirms previous studies by Isidori and Suminski, which showed that oral ingestion of 1.2-1.5 gram arginine and 1.2-1.5 gram lysine increased GH release 3-8 fold in comparison with placebo. In addition, we found that the AA mixture, reflecting soy protein (17 gram AA), with equal amounts of arginine and lysine as in the ARG+LYS testdrink, increased GH concentrations 2.2 peak fold more than arginine and lysine alone. We concluded that in addition to arginine and lysine, other amino acids are involved in the observed stimulation of $\mathrm{GH}$ release, directly or indirectly via conversion to another AA. The somatotropic effects of the amino acids reflecting soy protein composition, were unaffected whether these amino acids were orally administered as either intact or as partially hydrolysed soy protein. 
To the best of our knowledge, this is the only human study performed analysing the effects of variable chain length of proteins on GH secretion. Only one other animal study, performed in rats in which casein is used as protein source in a meal or as free amino acids, also showed no different results in $\mathrm{GH}$-concentrations after intake of a meal with dietary (casein) amino acids in free form or as complete casein proteins ${ }^{16}$.

The similar $\mathrm{GH}$ responses after ingestion of the AA-mixture and soy protein are associated with comparable peak values of amino acid concentrations (Figure 3). Absorption of the amino acids was slower after ingestion of the (intact or hydrolysed) proteins than after ingestion of the AA mixture, as indicated by the lower AUC and the lower time to peak of the plasma amino acid responses. This was however not associated with differences in $\mathrm{GH}$ responses, indicating that the absorption rate of the amino acids after oral ingestion was not of pivotal value for the $\mathrm{GH}$ responses. Hence, the underlying mechanism of the increased $\mathrm{GH}$ release after protein ingestion may be relate to $\mathrm{GH}$-secreting properties of insulin ${ }^{7,17,18}$, since increased insulin responses to protein or amino acid ingestion may play a role in the observed $\mathrm{GH}$ responses ${ }^{19,20}$. This effect is independent of plasma glucose responses, which were unaffected by protein or amino acid ingestion.

We showed a clear effect of intact soy protein on GH secretion; the next step should be to assess the effects of soy protein as part of a meal. Previous studies on the effects of meals on plasma $\mathrm{GH}$ have produced controversial results. Some studies showed an increase of $\mathrm{GH}$-concentrations after normal and high protein meals in humans ${ }^{6,21-23}$, while other studies showed decreased or unaffected GHsecretion after normal and high-protein meals ${ }^{14,23-25}$.

The clinical and physiological relevance of the results of this study remains to be investigated. These results show that in normal healthy women, GH-responses increase after oral ingestion of proteins. It is not known whether this effect also occurs in a GH-deficient population, such as in obese subjects, and if so, whether this has any physiolocical effects.

In conclusion, ingestion of soy protein, either hydrolysed or intact, as well as amino acids reflecting soy protein, stimulates GH release to a similar extent. Increased serum levels of insulin as well as peak amino acid concentration but not the absorption rate of AA, may be responsible for the somatotropic effects. Further investigations are necessary to elucidate the role of dietary protein in the regulation of plasma $\mathrm{GH}$ levels following meal ingestion. 


\section{REFERENCES}

1. Veldhuis JD, Roemmich JN, Richmond EJ, Rogol AD, Lovejoy JC, Sheffield-Moore M, Mauras N \& Bowers CY. Endocrine control of body composition in infancy, childhood, and puberty. Endocr Rev 200526114 146.

2. Hameed M, Lange KH, Andersen JL, Schjerling P, Kjaer M, Harridge SD \& Goldspink G. The effect of recombinant human growth hormone and resistance training on IGF-I mRNA expression in the muscles of elderly men. J Physiol 2004555 231-240.

3. Johannsson G \& Bengtsson BA. Growth hormone and the metabolic syndrome. J Endocrinol Invest 1999 22 41-46.

4. Scacchi M, Pincelli AI \& Cavagnini F. Growth hormone in obesity. Int J Obes Relat Metab Disord 199923 260-271.

5. Chromiak JA \& Antonio J. Use of amino acids as growth hormone-releasing agents by athletes. Nutrition 200218 657-661.

6. Knopf RF, Conn JW, Fajans SS, Floyd JC, Guntsche EM \& Rull JA. Plasma Growth Hormone Response To Intravenous Administration Of Amino Acids. J Clin Endocrinol Metab 196525 1140-1144.

7. Biller BM, Samuels MH, Zagar A, Cook DM, Arafah BM, Bonert V, Stavrou S, Kleinberg DL, Chipman JJ \& Hartman ML. Sensitivity and specificity of six tests for the diagnosis of adult GH deficiency. J Clin Endocrinol Metab 200287 2067-2079.

8. Groschl M, Knerr I, Topf HG, Schmid P, Rascher W \& Rauh M. Endocrine responses to the oral ingestion of a physiological dose of essential amino acids in humans. J Endocrinol 2003179 237-244.

9. Collier SR, Casey DP \& Kanaley JA. Growth hormone responses to varying doses of oral arginine. Growth Horm IGF Res 200515 136-139.

10. Welbourne TC. Increased plasma bicarbonate and growth hormone after an oral glutamine load. Am J Clin Nutr 199561 1058-1061.

11. Isidori A, Lo Monaco A \& Cappa M. A study of growth hormone release in man after oral administration of amino acids. Curr Med Res Opin 19817 475-481.

12. Suminski RR, Robertson RJ, Goss FL, Arslanian S, Kang J, DaSilva S, Utter AC \& Metz KF. Acute effect of amino acid ingestion and resistance exercise on plasma growth hormone concentration in young men. Int J Sport Nutr 19977 48-60.

13. Hoppe C, Molgaard C, Juul A \& Michaelsen KF. High intakes of skimmed milk, but not meat, increase serum IGF-I and IGFBP-3 in eight-year-old boys. Eur J Clin Nutr 200458 1211-1216.

14. Merimee TJ, Pulkkinen AJ \& Burton CE. Diet-induced alterations of hGH secretion in man. J Clin Endocrinol Metab 197642 931-937.

15. Abumrad NN, Rabin D, Diamond MP \& Lacy WW. Use of a heated superficial hand vein as an alternative site for the measurement of amino acid concentrations and for the study of glucose and alanine kinetics in man. Metabolism 198130 936-940.

16. Nolles JA, Van Straten EM, Bremer BI, Koopmanschap RE, Verstegen MW \& Schreurs VV. Dietary amino acids fed in free form and as protein components do not differently affect postprandial plasma insulin, glucagon, growth hormone and corticosterone responses in rats. J Anim Physiol Anim Nutr (Berl) 200690 289-299.

17. Rabinowitz D \& Zierler KL. A Metabolic Regulating Device Based On The Actions Of Human Growth Hormone And Of Insulin, Singly And Together, On The Human Forearm. Nature 1963199 913-915.

18. Muggeo M, Tiengo A, Fedele D \& Crepaldi G. Growth hormone response to insulin and to arginine in patients with familial hypercholesterolaemia. Atherosclerosis 197522 543-550.

19. van Loon L, Kruijshoop M, Menheere PP, Wagenmakers AJ, Saris WH \& Keizer HA. Amino acid ingestion strongly enhances insulin secretion in patients with long-term type 2 diabetes. Diabetes Care 200326 625-630.

20. van Loon $\mathrm{L}$, Kruijshoop M, Verhagen $\mathrm{H}$, Saris WH \& Wagenmakers AJ. Ingestion of protein hydrolysate and amino acid-carbohydrate mixtures increases postexercise plasma insulin responses in men. $J$ Nutr $20001302508-2513$.

21. Baker HW, Best JB, Burger HG \& Cameron DP. Plasma human growth hormone levels in response to meals: a reappraisal. Aust J Exp Biol Med Sci 197250 715-724. 


\section{CHAPTER 2}

22. Cree TC \& Schalch DS. Protein utilization in growth: effect of lysine deficiency on serum growth hormone, somatomedins, insulin, total thyroxine (T4) and triiodothyronine, free T4 index, and total corticosterone. Endocrinology 1985117 667-673.

23. Hunter WM, Friend JA \& Strong JA. The diurnal pattern of plasma growth hormone concentration in adults. J Endocrinol 196634 139-146.

24. Harber MP, Schenk S, Barkan AL \& Horowitz JF. Effects of dietary carbohydrate restriction with high protein intake on protein metabolism and the somatotropic axis. J Clin Endocrinol Metab 2005905175 5181.

25. Pallotta JA \& Kennedy PJ. Response of plasma insulin and growth hormone to carbohydrate and protein feeding. Metabolism 196817 901-908. 


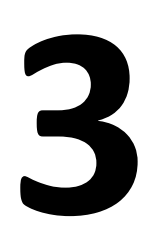

The effects of dietary protein on
the somatotropic axis; a comparison of soy, gelatin, alphalactalbumin and milk

ANNEKE J.A.H. VAN VUGHT, ARIE G. NIEUWENHUIZEN, MARGRIET A.B. VELDHORST, ROBERT-JAN M. BRUMMER, MARGRIET S. WESTERTERP-PLANTENGA

IN REVISION, 2009 


\section{ABSTRACT}

Introduction: Growth hormone $(\mathrm{GH})$ is an important regulator of growth and body composition. It has been shown that $\mathrm{GH}$ release can be promoted by administration of various amino acids, such as arginine and lysine, that are present in soy protein. We previously showed that oral ingestion of soy protein stimulates the $\mathrm{GH}$ release, it is not known however to which extent other proteins stimulate the $\mathrm{GH}$ secretion.

Methods: Ingestion of soy protein (soy), gelatin protein (gelatin), alpha-lactalbumin protein $(\alpha-\mathrm{lac})$ and milk protein (milk) were compared on their $\mathrm{GH}$ stimulating capacity. After oral ingestion of protein ( 0.6 gram protein per kg bodyweight), blood was sampled every $20 \mathrm{~min}$ for $5 \mathrm{~h}$ to analyse $\mathrm{GH}-$, amino acid-, insulin- and glucose-concentrations. The study was performed in eight healthy women (age: 1926 years, body mass index (BMI): $19-26 \mathrm{~kg} / \mathrm{m}^{2}$ ) in a randomized, single blind, placebo-controlled crossover design.

Results: $\mathrm{GH}$ responses were more increased after ingestion of gelatine $(8.2 \pm 1.1$ $\mu \mathrm{g} / \mathrm{L})$ compared with ingestion of soy, $\alpha$-lactalbumin and milk $(5.0 \pm 0.8 \mu \mathrm{g} / \mathrm{L}, 4.5 \pm$ $0.6 \mu \mathrm{g} / \mathrm{L}, 6.4 \pm 1.0 \mu \mathrm{g} / \mathrm{L}$ respectively) ( $\mathrm{p}<0.05$ ). After ingestion of each protein, $\mathrm{GH}$ responses were higher compared with placebo ingestion $(p<0.05)$. Simultaneously ingestion of gelatin resulted in the highest serum-arginine concentrations (ARG) compared with after ingestion of the other proteins $(p<0.05)$. Insulin as well as glucose concentrations were not different after ingestion of the various proteins $(\mathrm{p}<0.05)$.

Conclusion: The GH-promoting activity of protein depends on the protein source, in that, gelatin protein is the most potent $\mathrm{GH}$ stimulator. Arginine may be the responsible amino acid in the GH promoting effect of gelatin, although each protein may have its own specific AA-spectrum involved in the stimulation of the somatotropic axis 


\section{INTRODUCTION}

Growth hormone $(\mathrm{GH})$, a hormone originating from the anterior pituitary gland, is an important regulator of growth and body composition ${ }^{1}$. GH exerts its growth promoting effect through stimulation of the secretion of Insulin-Like Growth Factor I (IGF-I) from the target cells ${ }^{1}$. Low GH-concentrations may be involved in the pathogenesis of obesity, sarcopenia and growth retardation ${ }^{1-4}$.

It has been shown by many studies that GH secretion can be promoted by intravenous or oral administration of various amino acids (AAs), either alone or in combination ${ }^{5,6}$. Especially ingestion of the combination of the AAs arginine (ARG) and lysine (LYS) in a ratio of 1:1 was found to be a potent GH secretor ${ }^{7}$. Previously we found that ingestion of soy protein (SOY), containing relatively high amounts of ARG and LYS in approximately equal amounts, stimulates the GH secretion two fold more compared with a mixture of ARG and LYS ${ }^{8}$. From this, it can be concluded that besides ARG and LYS, also other AA stimulate the somatotropic axis, as indeed was shown for the AAs methionine, phenylalanine, histidine and glutamic acid ${ }^{6}$. Therefore, it is expected that also ingestion of other proteins than soy, with different $A R G / L Y S$ ratios and/or higher concentrations of certain AAs, influence the $G H$ secretion.

The objective of the present study was to examine the $\mathrm{GH}$ response after ingestion of different proteins. SOY was hypothesized being a relatively strong $\mathrm{GH}$ stimulator among the proteins because of the relatively high and equal amounts of ARG and LYS. We compared this protein with gelatin (gelatin) and alpha lactalbumin ( $\alpha$-lac) because of their distinct ARG:LYS ratios. Thus, gelatin contains relatively high amounts of ARG, but relatively low amounts of LYS (ARG:LYS, 1:0.45), while $\alpha$-lac contains relatively low amounts of ARG and high amounts of LYS (ARG:LYS, 1:5.8). In addition, we also tested milk protein (milk) as this protein is widely used in food products, and contains relatively high amounts of LYS, but lower amounts of ARG (ARG:LYS, 1:3.2).

\section{METHODS}

\section{Subjects}

Subjects were recruited via advertisements at the university. They underwent a screening procedure including medical history taking, measurement of bodyweight and height. Eight females were selected on the basis of being in good health, nondiabetic, non-smoker, non-vegetarian, using oral contraceptives, not using other medication, not spending more than three hours sport activities a week and at most moderate alcohol users ( $<10$ alcoholic consumptions per week). Only females 
were included, because in previous studies was found that females responded more consistently and with a greater increase in $\mathrm{GH}$ after ingestion of certain amino acids than men ${ }^{9,10}$. Their mean age was $21 \pm 1.5$ years, and their body mass index (BMI) was $22 \pm 1.8 \mathrm{~kg} / \mathrm{m}^{2}$. All tests were performed in the early follicular phase of each woman's menstrual cycle, to eliminate the confounding variable of changing serum estrogen concentrations. The Medical Ethics Committee of Maastricht University approved the study protocol and all subjects gave their written informed consent before participating in the study.

\section{Experimental design}

A randomized crossover study design was applied. Subjects reported to the laboratory for consumption of five different test drinks (soy, gelatin, $\alpha$-lactalbumin, milk and placebo), at separate test days. Each time, subjects arrived in the morning at the laboratory in a fasted state. They were instructed to fast from $10 \mathrm{pm}$ the night prior to the test day. A permanent canula was placed into a dorsal hand vein of the contralateral arm, and this hand was kept in a thermoregulated $\left(60^{\circ} \mathrm{C}\right)$ box to sample arterialized venous blood ${ }^{11}$. Blood sampling began 60 min after placement of the canula. Blood was sampled every $20 \mathrm{~min}$ for the next $5 \mathrm{~h}$. During blood sampling, subjects remained awake and were allowed to drink water ad libitum. Immediately after obtaining the first blood sample, subjects received a test drink. The test drink was based on 0.6 gram protein per kg bodyweight dissolved in 400 $\mathrm{ml}$ water with $20 \mathrm{ml}$ sugarfree syrup (Diaran, Cereal). The placebo test drink contained $400 \mathrm{ml}$ water with $20 \mathrm{ml}$ sugarfree syrup. The syrup was added for the taste and contained no protein and fat and a negligible amount of carbohydrates. The AA-composition of the proteins is shown in Table 1.

Table 1: AA composition of the proteins tested. Amount in g per $100 \mathrm{~g}$ of protein. $\alpha$-lac $=$ alpha lactalbumin

\begin{tabular}{lcccc}
\hline & Soy & Gelatin & $\alpha$-lac & Milk \\
\hline Arginine & 6.8 & 8.4 & 1.8 & 3.7 \\
Cysteine & 1.1 & 0.0 & 4.9 & 0.7 \\
Histidine & 2.3 & 0.9 & 2.8 & 2.8 \\
Isoleucine & 4.4 & 1.5 & 5.8 & 5.6 \\
Leucine & 7.1 & 3.0 & 11.0 & 10.0 \\
Lysine & 5.4 & 3.9 & 10.5 & 8.5 \\
Methionine & 1.1 & 0.9 & 1.2 & 2.9 \\
Phenylalanine & 4.6 & 1.9 & 4.0 & 5.0 \\
Threonine & 3.3 & 1.9 & 4.9 & 4.7 \\
Tryptophan & 1.1 & $<0.1$ & 3.8 & 1.5 \\
Tyrosine & 3.4 & 0.5 & 4.3 & 5.5 \\
Valine & 4.2 & 2.3 & 4.4 & 7.0 \\
\hline
\end{tabular}




\section{Blood analysis}

Arterialized venous blood was collected in clot tubes, containing 'Silica Clot Activator' (Becton Dickinson Vacutainer system; Becton Dickinson, Franklin Lakes, NJ), and in heparinized tubes (Becton Dickinson Vacutainer system; Becton Dickinson, Franklin Lakes, NJ). Blood in the clot tubes was allowed to cloth for 30 minutes and was centrifuged at $3000 \mathrm{rpm}, 4^{\circ} \mathrm{C}$ for $10 \mathrm{~min}$ to obtain serum. Serum was collected for determination of $\mathrm{GH}$ and amino acid $(\mathrm{AA})$ concentrations. Blood in heparinized tubes was kept on ice to minimize enzymatic reactions and centrifuged at $3000 \mathrm{rpm}$ at $4^{\circ} \mathrm{C}$ for $10 \mathrm{~min}$ to obtain plasma. Glucose and insulin analyses were performed in plasma. Each aliquot was frozen immediately in liquid nitrogen and stored at $-80^{\circ} \mathrm{C}$. All samples from the same subjects were run in the same assay.

The GH-concentrations were measured by using an ultrasensitive $\mathrm{GH}$ chemiluminescence immunoassay (Beckman Coulter, Harbor Blvd. Fullerton, U.S.A.). Insulin concentrations were measured by an electrochemiluminescence immunoassay (ELICA) (Roche Diagnostica, Hoffman-La Roche, Basel, Switzerland). Glucose concentrations were measured by using enzymatic assay (G6-PDH) (Roche Diagnostica, Hoffman-La Roche, Basel, Switzerland). The concentrations of the amino acids arginine, lysine, histidine, methionine, ornitine, phenylalanine and glutamic acid were measured using a HPLC system (Shimadzu, Duisburg, Germany). These AA were chosen to analyse, because these are supposed in previous studies to stimulate the $\mathrm{GH}$ response ${ }^{5-7,12-14}$.

\section{Statistics}

Data are presented as mean changes from baseline +/- standard error to the mean (SEM). Baseline ratings for $\mathrm{GH}$, insulin, glucose and AAs were not statistically significantly different among treatments, therefore delta concentrations were used for statistical analysis. Growth hormone, insulin, glucose and AA responses were calculated as incremental area under the curve (IAUC), peak values and time to peak (TTP) values. Statistical analyses of the data were performed using repeated measures analysis of variance (ANOVA), correcting for multiple analyses. Post hoc comparisons were made with the Fisher PLSD-test. A p-value $<0.05$ was regarded as statistically significant. All statistical tests were performed by using Statview SE Graphics software (version 4.5; Abacus Concepts Inc, Berkeley, CA, USA).

\section{RESULTS}

$\mathrm{GH}$ responses as determined by incemental area under the curve (IAUC) and peak values were increased after gelatin ingestion when compared with ingestion of soy, 
$\alpha$-lactalbumin, milk and placebo $(p<0.05)$. After ingestion of soy, $\alpha$-lactalbumin and milk, GH responses (IAUC and peak) were increased compared with placebo $(p<0.05)$. GH responses after ingestion of milk were delayed compared with $\mathrm{GH}$ concentrations after ingestion of the other proteins (Figure 1, Table 2).

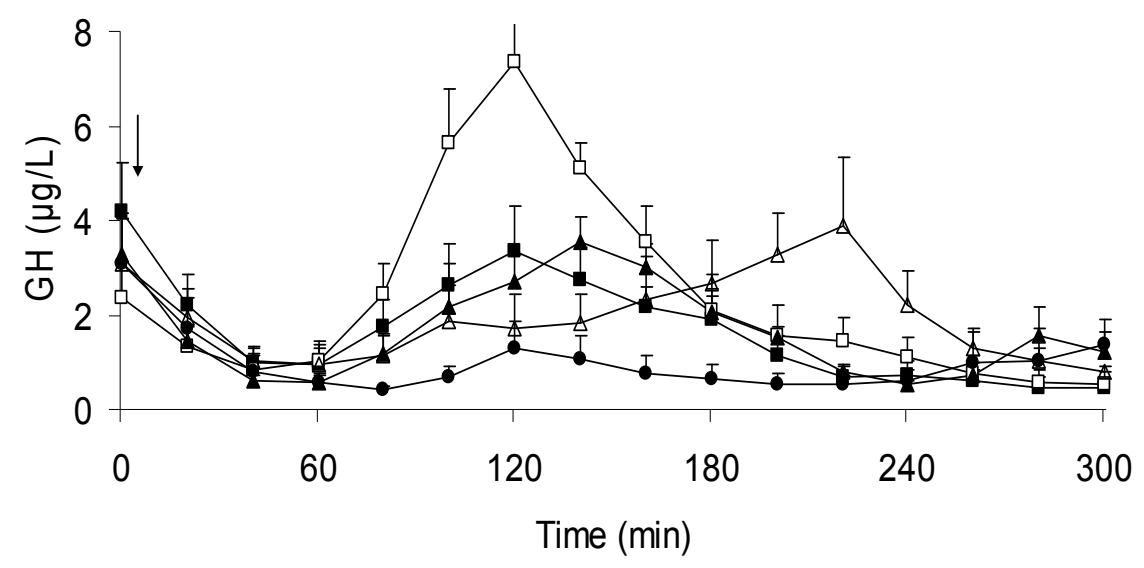

Figure 1: Growth hormone concentrations after ingestion of a testdrink containing soy protein (घ), gelatin protein $(\square)$, alpha lactalbumin protein $(\boldsymbol{\Delta})$, milk protein $(\Delta)$ and placebo $(\bullet)(n=8)$. Data are presented as mean $( \pm$ SEM) in lines. $\downarrow$ = ingestion of testdrink.

The insulin responses, determined as IAUC and peak values, were higher after ingestion of the proteins, compared with ingestion of the placebo drink $(p<0.05)$. There were no differences between the insulin concentrations after ingestion of the different proteins. There was no TTP difference between the insulin responses after ingestion of the different test drinks (Table 2).

The glucose concentrations, determined as IAUC and peak values were not differently affected by ingestion of the test drinks. There was no TTP difference between the glucose responses after ingestion of the different test drinks (Table 2). 


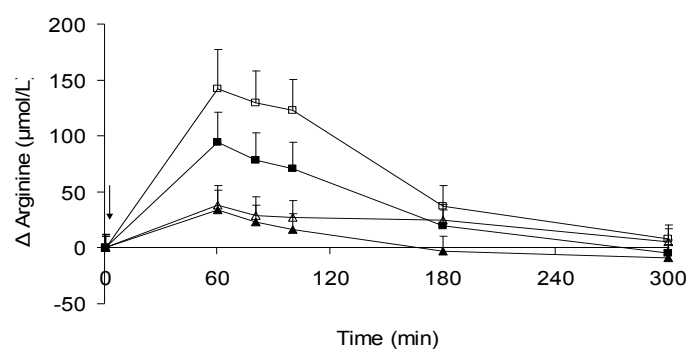

Figure 2: Changes in arginine concentrations after ingestion of a testdrink containing soy protein $(\boldsymbol{\square})$, gelatin protein $(\square)$, alpha lactalbumin protein $(\boldsymbol{\Delta})$ and milk protein $(\Delta)(n=8)$. Data are presented as mean $( \pm$ SEM) in lines. $\downarrow=$ ingestion of testdrink.

AA responses to protein ingestion as determined by IAUC and peak values are shown in Table 2. Arginine (ARG) concentrations were significantly higher (IAUC and peak) after ingestion of gelatin, compared with the other proteins $(p<0.05)$. Furthermore, ARG concentrations were higher after ingestion of soy compared with $\alpha$-lactalbumin and milk ( $p<0.05$ ) (Figure 2, Table 2). Ornitine (ORN) concentrations were significantly higher (AUC and peak) after ingestion of gelatin, compared with the other proteins $(p<0.05)$. Furthermore, ORN concentrations were high after ingestion of soy compared with $\alpha$-lactalbumin and milk $(p<0.05)$. Histidine (HIS) concentrations, expressed as AUC and peak value were higher after ingestion of soy or $\alpha$-lactalbumin compared with gelatin $(p<0.05)$. Lysine (LYS) concentrations were higher ( $A \cup C$ and peak value) after ingestion of $\alpha$-lactalbumin compared with the other proteins $(p<0.05)$. Methionine (MET) concentrations (IAUC, peak value) were higher after ingestion of milk compared with the other proteins $(p<0.05)$. Peak values of phenylalanine (PHE) were higher after ingestion of soy or $\alpha$-lactalbumin compared with gelatin or milk $(p<0.05)$. Peak values of glutamic acid (GLU) were higher after ingestion of gelatin compared with milk $(p<0.05)$ (Table 2$)$. 


\section{CHAPTER 3}

Table 2: Changes in $\mathrm{GH}$, insulin, glucose and amino acids after ingestion of a test drink with soy protein, gelatin protein, alpha lactalbumin protein, milk protein and placebo $(n=8)$, expressed as IAUC, peak-values and time to peak (TTP).

\begin{tabular}{|c|c|c|c|c|c|c|c|c|c|c|c|c|c|c|c|}
\hline \multirow[b]{3}{*}{$\mathrm{GH}(\min . \mu \mathrm{g} / \mathrm{L})$} & \multicolumn{15}{|c|}{ IAUC } \\
\hline & \multicolumn{3}{|c|}{ Placebo } & \multicolumn{3}{|c|}{ Soy } & \multicolumn{3}{|c|}{ Gelatin } & \multicolumn{3}{|c|}{ Alpha lactalbumin } & \multicolumn{3}{|c|}{ Milk } \\
\hline & 184.0 & \pm & 52.1 & 374.0 & \pm & $49.6^{a}$ & 641.4 & \pm & $74.6^{\text {a.b.c.d }}$ & 421.4 & \pm & $44.2^{\mathrm{a}}$ & 477.2 & \pm & $53.4^{\mathrm{a}}$ \\
\hline Insulin (min.mU/L) & -256.1 & \pm & 166.0 & 2599.5 & \pm & $254.8^{\mathrm{a}}$ & 1747.3 & \pm & $459.1^{\mathrm{a}}$ & 2249.9 & \pm & $344.1^{\mathrm{a}}$ & 1837.6 & \pm & $423.1^{\mathrm{a}}$ \\
\hline Arginine (min.mmol/L) & & & & 10.6 & \pm & $1.7^{\mathrm{d}}$ & 18.7 & \pm & $1.9^{\text {b.c.d }}$ & 1.8 & \pm & 1.0 & 6.2 & \pm & $1.0^{c}$ \\
\hline Lysine (min.mmol/L) & & & & 23.7 & \pm & 3.5 & 17.0 & \pm & 2.5 & 48.1 & \pm & $3.8^{\text {b.d.e }}$ & 25.2 & \pm & 2.1 \\
\hline Histidine (min.mmol/L) & & & & 5.3 & \pm & $1.5^{e}$ & 1.0 & \pm & 1.1 & 6.3 & \pm & $1.5^{\mathrm{e}}$ & 4.8 & \pm & 1.1 \\
\hline Ornitine (min.mmol/L) & & & & 7.9 & \pm & $1.1^{c . d}$ & 10.3 & \pm & $1.3^{b . c . d}$ & -1.9 & \pm & 0.8 & 3.5 & \pm & $0.7^{c}$ \\
\hline Phenylalanine (min.mmol/L) & & & & 7.6 & \pm & $1.0^{\text {c.d.e }}$ & 1.5 & \pm & 0.6 & 5.0 & \pm & $0.7^{\mathrm{e}}$ & 4.8 & \pm & $0.3^{e}$ \\
\hline Glutamic acid (min.mmol/L) & & & & 0.2 & \pm & 2.3 & -0.5 & \pm & 1.2 & -1.1 & \pm & 1.4 & -0.6 & \pm & 1.5 \\
\hline
\end{tabular}

\begin{tabular}{|c|c|c|c|c|c|c|c|c|c|c|c|c|c|c|c|}
\hline \multirow[b]{3}{*}{$\mathrm{GH}(\mu \mathrm{g} / \mathrm{L})$} & \multicolumn{15}{|c|}{ Peak } \\
\hline & \multicolumn{3}{|c|}{ Placebo } & \multicolumn{3}{|c|}{ Soy } & \multicolumn{3}{|c|}{ Gelatin } & \multicolumn{3}{|c|}{ Alpha lactalbumin } & \multicolumn{3}{|c|}{ Milk } \\
\hline & 2.2 & \pm & 0.8 & 5.0 & \pm & $0.8^{\mathrm{a}}$ & 8.2 & \pm & $1.1^{a . b . c}$ & 4.5 & \pm & $0.6^{\mathrm{a}}$ & 6.4 & \pm & $1.0^{\mathrm{a}}$ \\
\hline Insulin (mU/L) & 8.5 & \pm & 1.1 & 32.1 & \pm & $7.7^{\mathrm{a}}$ & 32.3 & \pm & $5.9^{\mathrm{a}}$ & 33.7 & \pm & $4.2^{\mathrm{a}}$ & 35.3 & \pm & $6.2^{\mathrm{a} \cdot \mathrm{b}}$ \\
\hline Glucose (mmol/L) & 5.3 & \pm & 0.1 & 5.5 & \pm & 0.1 & 5.4 & \pm & 0.1 & 5.3 & \pm & 0.2 & 5.4 & \pm & 0.1 \\
\hline Arginine (mmol/L) & & & & 204.5 & \pm & $11.4^{c, d}$ & 233.6 & \pm & $20.9^{\text {b.c.d }}$ & 129.2 & \pm & 3.9 & 121.6 & \pm & 11.0 \\
\hline Lysine (mmol/L) & & & & 354.4 & \pm & 9.3 & 302.1 & \pm & 20.6 & 546.0 & \pm & $38.0^{\text {b.d.e }}$ & 288.0 & \pm & 16.56 \\
\hline Ornitine (mmol/L) & & & & 110.1 & \pm & $7.0^{c . d}$ & 146.5 & \pm & $11.6^{\text {b.c.d }}$ & 59.3 & \pm & 3.4 & 72.8 & \pm & $3.9^{c}$ \\
\hline Phenylalanine (mmol/L) & & & & 125.1 & \pm & $7.5^{\text {d.e }}$ & 87.9 & \pm & 3.9 & 117.1 & \pm & $6.4^{\text {d.e }}$ & 89.8 & \pm & 2.8 \\
\hline Glutamic acid (mmol/L) & & & & 124.9 & \pm & 7.9 & 132.3 & \pm & $4.0^{\mathrm{d}}$ & 125.0 & \pm & 8.8 & 104.2 & \pm & 3.9 \\
\hline
\end{tabular}

\begin{tabular}{|c|c|c|c|c|c|c|c|c|c|c|c|c|c|c|c|}
\hline \multirow[b]{3}{*}{ GH (min) } & \multicolumn{15}{|c|}{ TTP } \\
\hline & \multicolumn{3}{|c|}{ Placebo } & \multicolumn{3}{|c|}{ Soy } & \multicolumn{3}{|c|}{ Gelatin } & \multicolumn{3}{|c|}{ Alpha lactalbumin } & \multicolumn{3}{|c|}{ Milk } \\
\hline & 180 & \pm & 30 & 122 & \pm & $12^{\text {a.d }}$ & 122 & \pm & $6^{\text {a.d }}$ & 122 & \pm & $10^{\text {a.d }}$ & 190 & \pm & 22 \\
\hline Insulin (min) & 30 & \pm & 18 & 30 & \pm & 18 & 30 & \pm & 18 & 26 & \pm & 4 & 20 & \pm & 0 \\
\hline Arginine (min) & & & & 56 & \pm & 18 & 58 & \pm & 18 & 50 & \pm & 18 & 60 & \pm & 8 \\
\hline Lysine (min) & & & & 60 & \pm & $7^{d}$ & 52 & \pm & 18 & 52 & \pm & 18 & 42 & \pm & 2 \\
\hline Ornitine (min) & & & & 62 & \pm & 8 & 52 & \pm & 18 & 46 & \pm & 4 & 50 & \pm & 8 \\
\hline Phenylalanine (min) & & & & 66 & \pm & 18 & 56 & \pm & 18 & 56 & \pm & 18 & 56 & \pm & 8 \\
\hline Glutamic acid (min) & & & & 62 & \pm & $7^{d}$ & 58 & \pm & $5^{d}$ & 58 & \pm & 18 & 50 & \pm & 8 \\
\hline
\end{tabular}

Data are presented as mean ( \pm SEM). ${ }^{a}$ Significantly higher than after placebo ingestion ${ }^{b}$ Significantly higher than after soy protein ingestion 'Significantly higher than after alpha lactalbumin protein ingestion ${ }^{\mathrm{d}}$ Significantly higher than after milk protein ingestion ${ }^{\mathrm{e}}$ Significantly higher than after gelatin protein ingestion

\section{DISCUSSION}

This study showed that oral intake of protein stimulates the $\mathrm{GH}$ response, moreover, the GH-promoting activity of protein depends on the protein-source, in that, gelatin protein (gelatin) ingestion stimulates the $\mathrm{GH}$ response to a higher extent than ingestion of the proteins; soy (soy), alpha lactalbumin ( $\alpha$-lactalbumin) and milk (milk).

Studies investigating the effect of protein on the somatotropic axis mainly tested milk and found positive associations between milk intake and somatotropic hor- 
mones among adults and children ${ }^{15-23}$. For instance, in Mongolian children, the GH response was increased after daily intake of $720 \mathrm{ml}$ milk for 4 weeks, compared with baseline ${ }^{23}$. Furthermore, twelve year old girls showed approximately $10 \%$ higher IGF-1 levels after consumption of $300 \mathrm{ml}$ milk per day for 6 months, compared with their controls ${ }^{15}$. These findings are in accordance with our finding that milk intake increases the $\mathrm{GH}$ response when compared with placebo.

Furthermore a study by Ohsumi et al. investigated the influence of gelatin compared with casein protein on $\mathrm{GH}$ secretion. In contrast to our findings, they found reduced $\mathrm{GH}$ concentrations after ingestion of a lower quality of dietary protein (i.e. gelatine) compared with a higher quality dietary protein (i.e. casein) in aged rats ${ }^{24}$. In their study, $\mathrm{GH}$ concentrations were measured once after an ingestion-period of $5 \mathrm{~h}$, which is different from our protocol where we measured $\mathrm{GH}$ concentrations every 20 min after ingestion of a constant amount of protein. The different protocols used may have influenced the results, since casein is known to be aggregated into a gel in the stomach which could delay the absorption rate of AA in the intestine and therefore delay the $\mathrm{GH}$ response after ingestion of casein protein, compared with gelatine protein ${ }^{25,26}$.

The mechanism behind this source-dependent protein-induced $\mathrm{GH}$ secretion, with gelatin being the most potent stimulator of $\mathrm{GH}$ release, remains unclear. Gelatin is low in essential amino acids compared with the proteins soy, milk and $\alpha$ lactalbumin, however it contains the highest amounts of arginine (ARG) among the tested proteins. ARG is widely known and used as a GH stimulating amino acid ${ }^{27-29}$ and therefore could clarify the GH promoting effect of gelatin, since ARG intake as well as serum concentrations of ARG were higher after intake of gelatin compared with the other proteins. Simultaneously with ARG concentrations, serum ornithine (ORN) concentrations were higher after ingestion of gelatin compared with the other proteins. ARG is converted into ORN in the urea cycle ${ }^{30}$ and therefore it is not surprising that these amino acids are both present in a higher extent after ingestion of gelatin. Also ORN is known to stimulate the $\mathrm{GH}$ secretion ${ }^{6}$.

Furthermore, soy contains relatively high concentrations of ARG and both serum ARG and ORN concentrations were significantly increased compared with concentrations after intake of milk and $\alpha$-lactalbumin. In our previous work we found that soy stimulates the $\mathrm{GH}$ secretion to a higher extent than a mixture of ARG and lysine (LYS), which indicates that also other AAs than ARG and LYS are involved in the GH secretion ${ }^{8}$. This result is confirmed by this study, showing that $\alpha$-lactalbumin and milk also increase the GH response, but in IAUC and peak not different from soy. Alpha-lactalbumin contains higher amounts of LYS and intake of $\alpha$-lactalbumin results in higher LYS concentrations compared with the other proteins. Milk contains higher amounts of methionine (MET) and the intake of milk results in higher MET concentrations compared with the other proteins. LYS as well as MET are known to stimulate the $\mathrm{GH}$ secretion ${ }^{6}$. This finding indicates that the presence of 
specific GH stimulating AAs is more important than the ratio of ARG:LYS in a certain protein.

After ingestion of milk, the GH peak was delayed compared with GH peaks after ingestion of the other proteins. This could be explained by the effects of casein in the stomach. Casein is known to be aggregated into a gel in the stomach and therefore AA absorption could be delayed ${ }^{25,26}$. In our study we found that after ingestion of milk, AA-concentrations increase and stay at a certain level for a longer time, compared with the other protein, resulting in a AA-plateau which may explain the delayed $\mathrm{GH}$ peak after ingestion of milk (Figure 2). In spite of the delayed GH peak, GH IAUC and GH peak values were not different between soy, alphalactalbumin and milk.

Furthermore, in our results we did not find different glucose and insulin concentrations after ingestion of the various proteins, which indicates that glucose as well as insulin are not responsible for the differences in degree of $\mathrm{GH}$ stimulation after ingestion of the proteins.

The clinical and physiological relevance of the results of this study remains to be investigated. These results show that in lean healthy women, GH-responses increase after oral ingestion of proteins and in particular gelatin protein. It is not known whether this effect also occurs in a GH-deficient population, such as in obese subjects, and if so, whether this has any physiolocical effects.

Thus, GH concentrations are increased after ingestion of protein, however, the GHpromoting activity of protein depends on the protein-source, in that, gelatin protein is the most potent $\mathrm{GH}$ stimulator. Arginine may be the responsible amino acid in the GH promoting effect of gelatin, although each protein may have its own specific AA-spectrum involved in the stimulation of the somatotropic axis. 


\section{REFERENCES}

1. Veldhuis JD, Roemmich JN, Richmond EJ, Rogol AD, Lovejoy JC, Sheffield-Moore M, Mauras N \& Bowers CY. Endocrine control of body composition in infancy, childhood, and puberty. Endocr Rev 200526114 146.

2. Hameed M, Lange KH, Andersen JL, Schjerling P, Kjaer M, Harridge SD \& Goldspink G. The effect of recombinant human growth hormone and resistance training on IGF-I mRNA expression in the muscles of elderly men. J Physiol 2004555 231-240.

3. Johannsson G \& Bengtsson BA. Growth hormone and the metabolic syndrome. J Endocrinol Invest 1999 22 41-46.

4. Scacchi M, Pincelli Al \& Cavagnini F. Growth hormone in obesity. Int J Obes Relat Metab Disord 199923 260-271.

5. Chromiak JA \& Antonio J. Use of amino acids as growth hormone-releasing agents by athletes. Nutrition 200218 657-661.

6. Knopf RF, Conn JW, Fajans SS, Floyd JC, Guntsche EM \& Rull JA. Plasma Growth Hormone Response to Intravenous Administration of Amino Acids. J Clin Endocrinol Metab 196525 1140-1144.

7. Isidori A, Lo Monaco A \& Cappa M. A study of growth hormone release in man after oral administration of amino acids. Curr Med Res Opin 19817 475-481.

8. van Vught AJ, Nieuwenhuizen AG, Brummer RJ \& Westerterp-Plantenga MS. Effects of oral ingestion of amino acids and proteins on the somatotropic axis. J Clin Endocrinol Metab 200893 584-590.

9. Merimee TJ, Rabinowtitz D \& Fineberg SE. Arginine-initiated release of human growth hormone. Factors modifying the response in normal man. N Engl J Med 1969280 1434-1438.

10. Sartorio A, Agosti F, Marazzi N, Trecate L, Silvestri G, Lafortuna C, Cappa M, De Palo E, Faglia G, Corradini C, Cella S, Rigamonti A \& Muller EE. Gender-, age-, body composition- and training workload-dependent differences of $\mathrm{GH}$ response to a discipline-specific training session in elite athletes: a study on the field. $J$ Endocrinol Invest 200427 121-129.

11. Abumrad NN, Rabin D, Diamond MP \& Lacy WW. Use of a heated superficial hand vein as an alternative site for the measurement of amino acid concentrations and for the study of glucose and alanine kinetics in man. Metabolism 198130 936-940.

12. Castell LM, Poortmans JR \& Newsholme EA. Does glutamine have a role in reducing infections in athletes? Eur J Appl Physiol Occup Physiol 199673 488-490.

13. Walsh NP, Blannin AK, Robson PJ \& Gleeson M. Glutamine, exercise and immune function. Links and possible mechanisms. Sports Med 199826 177-191.

14. Welbourne TC. Increased plasma bicarbonate and growth hormone after an oral glutamine load. $A m \mathrm{~J}$ Clin Nutr 199561 1058-1061.

15. Cadogan J, Eastell R, Jones N \& Barker ME. Milk intake and bone mineral acquisition in adolescent girls: randomised, controlled intervention trial. Bmj 1997315 1255-1260.

16. Giovannucci E, Pollak M, Liu Y, Platz EA, Majeed N, Rimm EB \& Willett WC. Nutritional predictors of insulin-like growth factor I and their relationships to cancer in men. Cancer Epidemiol Biomarkers Prev $20031284-89$.

17. Heaney RP, McCarron DA, Dawson-Hughes B, Oparil S, Berga SL, Stern JS, Barr SI \& Rosen CJ. Dietary changes favorably affect bone remodeling in older adults. J Am Diet Assoc 199999 1228-1233.

18. Holmes MD, Pollak MN, Willett WC \& Hankinson SE. Dietary correlates of plasma insulin-like growth factor I and insulin-like growth factor binding protein 3 concentrations. Cancer Epidemiol Biomarkers Prev 200211 852-861.

19. Hoppe C, Molgaard C, Juul A \& Michaelsen KF. High intakes of skimmed milk, but not meat, increase serum IGF-I and IGFBP-3 in eight-year-old boys. Eur J Clin Nutr 200458 1211-1216.

20. Hoppe C, Udam TR, Lauritzen L, Molgaard C, Juul A \& Michaelsen KF. Animal protein intake, serum insulin-like growth factor I, and growth in healthy 2.5-y-old Danish children. Am J Clin Nutr 200480447 452.

21. Ma J, Giovannucci E, Pollak M, Chan JM, Gaziano JM, Willett W \& Stampfer MJ. Milk intake, circulating levels of insulin-like growth factor-I, and risk of colorectal cancer in men. J Natl Cancer Inst 2001931330 1336. 


\section{CHAPTER 3}

22. Rogers IS, Gunnell D, Emmett PM, Glynn LR, Dunger DB \& Holly JM. Cross-sectional associations of diet and insulin-like growth factor levels in 7- to 8-year-old children. Cancer Epidemiol Biomarkers Prev 2005 14 204-212.

23. Rich-Edwards JW, Ganmaa D, Pollak MN, Nakamoto EK, Kleinman K, Tserendolgor U, Willett WC \& Frazier AL. Milk consumption and the prepubertal somatotropic axis. Nutr J 2007628.

24. Ohsumi M, Shi X, Tuchiya T, Tujioka K, Lyou S, Hayase K \& Yokogoshi H. The role of growth hormone and amino acids on brain protein synthesis in aged rats given proteins of different quantity and quality. Amino Acids 200732 247-253.

25. Boirie $Y$, Dangin M, Gachon P, Vasson MP, Maubois JL \& Beaufrere B. Slow and fast dietary proteins differently modulate postprandial protein accretion. Proc Natl Acad Sci U S A 199794 14930-14935.

26. Dangin M, Boirie Y, Garcia-Rodenas C, Gachon P, Fauquant J, Callier P, Ballevre O \& Beaufrere B. The digestion rate of protein is an independent regulating factor of postprandial protein retention. $\mathrm{Am} J$ Physiol Endocrinol Metab 2001280 E340-348.

27. Collier SR, Casey DP \& Kanaley JA. Growth hormone responses to varying doses of oral arginine. Growth Horm IGF Res 200515 136-139.

28. Gunn IR. Tests for growth hormone deficiency. Lancet 19861 47-48.

29. Saggese G, Ranke MB, Saenger P, Rosenfeld RG, Tanaka T, Chaussain JL \& Savage MO. Diagnosis and treatment of growth hormone deficiency in children and adolescents: towards a consensus. Ten years after the Availability of Recombinant Human Growth Hormone Workshop held in Pisa, Italy, 27-28 March 1998. Horm Res 199850 320-340.

30. Flynn NE, Bird JG \& Guthrie AS. Glucocorticoid regulation of amino acid and polyamine metabolism in the small intestine. Amino Acids 2008. 


\section{4}

\section{Somatotropic responses to soy protein alone and as part of a}

\section{meal}

ANNEKE J.A.H. VAN VUGHT, ARIE G. NIEUWENHUIZEN, ROBERT-JAN M. BRUMMER, MARGRIET S. WESTERTERP-PLANTENGA

EUROPEAN JOURNAL OF ENDOCRINOLOGY 2008;159:15-18 


\section{ABSTRACT}

Context: Growth hormone (GH) is an important regulator of growth and body composition. We previously showed that $\mathrm{GH}$ release can be promoted by oral ingestion of soy protein, it is not known however whether these somatotropic effects of soy protein are also present when soy protein is ingested as part of a complete meal.

Objective/design: We compared effects of oral ingestion of soy protein alone with effects of a meal containing the same amount of soy protein on $\mathrm{GH}$ secretion in six healthy women (body mass index $(\mathrm{BMI})=19-26 \mathrm{~kg} / \mathrm{m}^{2} ; 19-36$ years), in a randomized crossover design. During the complete experiment serum $\mathrm{GH}$, insulin and glucose were determined every 20 minutes.

Results: GH responses as determined by area under the curve (AUC) and peak values were lower after ingestion of the meal, in comparison with $\mathrm{GH}$ responses after the soy protein consumption alone $(p<0.05)$, and did not differ from the placebo condition. Glucose-responses and insulin-responses, both determined as area under the curve (AUC) and peak values, were higher after ingestion of the meal, compared with these after ingestion of the protein-drink or the placebo $(p<0.05)$.

Conclusions: The somatotropic effect of soy protein is reduced and delayed when soy protein is ingested as part of a complete meal. Dietary carbohydrates, by increasing serum levels of glucose and insulin concentration, as well as dietary fat, may have interfered with the somatotropic effects of soy protein. 


\section{INTRODUCTION}

Growth hormone $(\mathrm{GH})$, a hormone originating from the anterior pituitary gland, is an important regulator of growth and body composition ${ }^{1}$. GH exerts its growth promoting effect (typically of fat-free mass) through stimulation of the secretion of Insulin-Like Growth Factor I (IGF-I) from the target cells ${ }^{1}$.

It has been shown by many authors that $\mathrm{GH}$ secretion can be promoted by intravenous or oral administration of various amino acids ${ }^{2,3}$. The stimulatory effect of amino acids on $\mathrm{GH}$ secretion is also present when ingested as proteins. Our previous study showed that $\mathrm{GH}$ secretion did not differ after ingestion of an amino acid mixture from that of soy protein, with comparable amino acid content ${ }^{4}$.

It is not known whether the somatotropic effect of soy protein is still present when it is ingested as part of a complete meal. No study compared the effect of protein alone with a meal on GH-secretion. Studies on the effects of meals in general on plasma GH showed controversial results. It has been reported that after a high protein meal, $\mathrm{GH}$ is increased ${ }^{5}$ and after a high-carbohydrate meal, $\mathrm{GH}$ is first decreased, but increased in late postprandial phases ${ }^{6}$. However no change in $\mathrm{GH}$ concentrations were found after 1 week of a low carbohydrate, high fat and high protein diet ${ }^{7}$. Another study found that high carbohydrate diets suppress growth hormone secretion, whereas high-fat diets and high protein diets of similar caloric value have no measurable effect ${ }^{8}$.

The reason for the inconsistency in above-mentioned studies is unclear. It may be that either the protein content of the meal was insufficient to increase GH or that other meal-components interfere with protein on $\mathrm{GH}$ concentrations. Therefore, this study aims to compare the effects of protein given alone or combined with carbohydrates and fat on $\mathrm{GH}$ secretion.

\section{METHODS}

\section{Subjects}

Subjects were recruited via advertisements at the university. Six healthy young females (age $24 \pm 5.8$ years, BMI $22 \pm 2.5 \mathrm{~kg} / \mathrm{m}^{2}$ ) participated. Each subject was in good health, non-smoker, using contraceptives, free of any other medication and spent no more than three hours a week on sport activities. The Medical Ethics Committee of Maastricht University approved the study protocol and all subjects gave their written informed consent before participating in the study. 


\section{Experimental design}

A randomized crossover study design was applied. Subjects reported to the laboratory for consumption of 3 different test products (placebo, soy protein alone, or a meal containing soy protein, see Table 1), at separate test days. Each time, subjects arrived at the laboratory in a fasted state, in the morning. They were instructed to fast from $10 \mathrm{pm}$ the night prior to the test day. A permanent cannula was inserted into a dorsal vein of the hand, for venous blood sampling ${ }^{9}$. Blood sampling began 60 min after placement of the cannula. Blood was sampled every 20 min for the next $5 \mathrm{~h}$. During blood sampling, subjects remained awake and fasted and were allowed to drink water ad libitum. Immediately after obtaining the first blood sample, subjects received a test product. The composition of the test products is described in Table 1.

Table 1: Composition of the tests conditions, based on a subject of $70 \mathrm{~kg}$.

\begin{tabular}{cccc}
\hline & Soy protein-drink & Meal & Placebo \\
\hline Volume $(\mathrm{g})$ & 467 & 834 & 500 \\
Soy protein $(\mathrm{g})$ & 42 & 42 & - \\
Carbohydrates $(\mathrm{g})$ & - & 92.4 & - \\
Fat $(\mathrm{g})$ & - & 14.92 & - \\
Sugar free syrup $(\mathrm{ml})$ & - & - & 40 \\
Viscosity & Liquid & Semi-solid & Liquid \\
\hline
\end{tabular}

\section{Blood analysis}

Arterialized venous blood was collected in cloth tubes (Becton Dickinson Vacutainer system; Becton Dickinson, Franklin Lakes, NJ) and was allowed to cloth for 30 minutes and was centrifuged at $3000 \mathrm{rpm}, 4^{\circ} \mathrm{C}$ for $10 \mathrm{~min}$ to obtain serum. Serum was collected for determination of $\mathrm{GH}$, insulin and glucose concentrations. Each serum aliquot was frozen immediately in liquid nitrogen and stored at $-80^{\circ} \mathrm{C}$, until analysis. All samples from the same subjects were run in the same assay.

The $\mathrm{GH}$-concentrations were measured by using an ultrasensitive $\mathrm{GH}$ chemiluminescence immunoassay (Beckman Coulter, Harbor Blvd. Fullerton, U.S.A.).

Insulin concentrations were measured by an electrochemiluminescence immunoassay (Roche Diagnostica, Hoffman-La Roche, Basel, Switzerland). Glucose concentrations were measured by using enzymatic assay (Roche Diagnostica, Hoffman-La Roche, Basel, Switzerland).

\section{Statistics}

All data are expressed as median \pm SEM. Statview SE+Graphics (1988;Abacus Concepts, Berkely, CA, USA) was used for the analysis. Growth hormone, insulin and glucose responses were calculated as area under the curve (AUC), peak values 
and time to peak (TTP) values. Since the data was not normally distributed, Kruskall-Wallis tests (non-parametric), were performed. Mann-Whitney tests were performed to locate possible significant differences. Statistical significance was set at $p<0.05$.

\section{RESULTS}

Growth hormone responses as determined by area under the curve (AUC) and peak values were increased after soy protein ingestion when compared with placebo( $p<0.05)$. GH responses were significantly higher at $t=260$ and $t=280$ after ingestion of the meal compared with placebo $(p<0.05)$. No differences in AUC and peak values were found in $\mathrm{GH}$ responses after ingestion of the meal compared with the placebo. GH responses (AUC and peak values) were lower after ingestion of the meal then after soy protein alone $(p<0.05)$. Time to peak concentration (TTP) was later after ingestion of the meal than after ingestion of the protein-drink and the placebo $(p<0.05)$ and TTP was later after the placebo than after the protein-drink( $\mathrm{p}<0.05$ ) (Figure 1, Table 2).

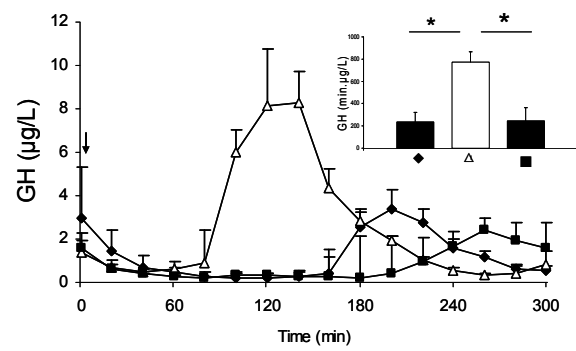

Figure 1: Growth hormone concentrations after ingestion of a placebo-testdrink $(\bullet)$, soy protein drink $(\Delta)$, and meal $(\boldsymbol{\square})(\mathrm{n}=6)$. Data are presented as medians ( \pm SEM) in lines and bars(AUC). $\downarrow=$ ingestion of testdrink. ${ }^{*}=p<0.05$

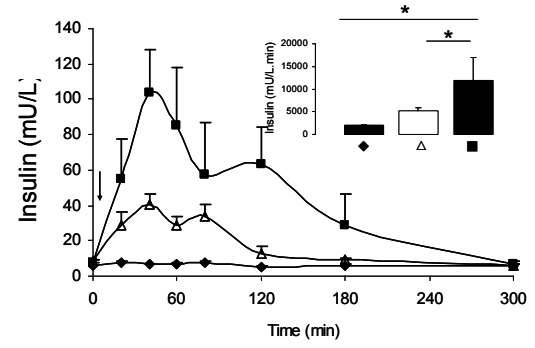

Figure 2: Insulin concentrations after ingestion of a placebo-testdrink $(\bullet)$, soy protein drink $(\Delta)$, and meal (घ) $(n=6)$. Data are presented as medians ( \pm SEM) in lines and bars(AUC). * = $p<0.05$.

The glucose-concentrations and insulin-concentrations, both determined as AUC and peak values, were higher after ingestion of the meal, compared with ingestion of the protein-drink or the placebo $(p<0.05)$. Ingestion of the soy protein-drink did not affect glucose or insulin responses (AUC and peak values), compared with placebo. No difference between the conditions was found in TTP of glucose and insulin concentrations (Table 2). 
Table 2: Blood parameters after ingestion of a placebo-testdrink, soy protein-drink and a meal $(n=6)$, expressed as AUC, peak-values and time to peak, TTP.

Data are presented as medians ( \pm SEM).

\begin{tabular}{|c|c|c|c|}
\hline & \multicolumn{3}{|c|}{ AUC } \\
\hline & Placebo & Soy protein & Meal \\
\hline $\mathrm{GH}(\mu \mathrm{g} / \mathrm{L} . \mathrm{min})$ & $235 \pm 87$ & $772 \pm 96^{a}$ & $245 \pm 122^{b}$ \\
\hline Insulin (mU/L.min) & $1972 \pm 189$ & $5185 \pm 753$ & $11910 \pm 5042^{a, b}$ \\
\hline \multirow[t]{3}{*}{ Glucose (mmol/L.min) } & $50 \pm 31$ & $37 \pm 26$ & $231 \pm 32^{\mathrm{a}, \mathrm{b}}$ \\
\hline & \multicolumn{3}{|c|}{ Peak } \\
\hline & Placebo & Soy protein & Meal \\
\hline $\mathrm{GH}(\mu \mathrm{g} / \mathrm{L})$ & $4 \pm 2$ & $10 \pm 5^{a}$ & $5 \pm 4^{b}$ \\
\hline \multirow[t]{3}{*}{ Insulin (mU/L) } & & $49 \pm 6$ & $105 \pm 116^{b}$ \\
\hline & \multicolumn{3}{|c|}{ TTP } \\
\hline & Placebo & Soy protein & Meal \\
\hline $\mathrm{GH}(\min )$ & $190 \pm 9$ & $120 \pm 8^{a}$ & $260 \pm 19^{\mathrm{a}, \mathrm{b}}$ \\
\hline Insulin (min) & . & $40 \pm 8$ & $50 \pm 15$ \\
\hline Glucose (min) & . & . & $40 \pm 4$ \\
\hline
\end{tabular}

a $<0.05$ compared with the placebo-drink (Mann-Whitney).

${ }_{\mathrm{p}}^{\mathrm{b}}<0.05$ compared with the soy protein-drink (Mann-Whitney).

\section{DISCUSSION}

It was shown that the somatotropic effect of soy protein, as had been shown before, was reduced and delayed when soy protein is ingested as part of a complete meal. This may indicate that besides soy protein, carbohydrates and/or fat play an important modulating role in the postprandial secretion of GH after ingestion of a high-protein meal. Thus, either carbohydrates or fat, or both carbohydrates and fat, are likely to have interfered with the $\mathrm{GH}$-promoting effect of soy protein.

To the best of our knowledge, this is the only human study performed, assessing the effects of a soy protein alone and as part of a complete meal on $\mathrm{GH}$ secretion. Two previous studies compared the effects of intakes of glucose, protein and glucose plus protein on plasma GH concentrations. Pallotta and Kennedy showed a delayed increase of $\mathrm{GH}$-concentrations ( $5 \mathrm{~h}$ after ingestion) following glucose (100 gram) and starch (700 gram, equivalent to 100 gram glucose) after the blood sugar has fallen, and an acute increase of $\mathrm{GH}$-concentrations ( $2 \mathrm{~h}$ after ingestion) following the protein intake (60 gram). No effect was shown after ingestion of glucose plus protein ${ }^{10}$. Also Rabinowitz showed a delayed increase of $\mathrm{GH}$ after intake of glucose (100 gram) and an acute increase of GH after intake of beef ( 64 gram proteins, 3 grams fat), but a blunted response after a mixed-substrate meal (glucose plus beef) ${ }^{5}$. Based upon these studies, it is likely that carbohydrates may have contributed to the blunted $\mathrm{GH}$ - response of soy protein ingestion after intake of a mixed meal, presumably through elevation of plasma glucose concentrations. Indeed, hyperglycaemia is associated with a decrease in plasma $\mathrm{GH}^{11}$, while hypo- 
glycaemia is a potent stimulator of plasma $\mathrm{GH}^{12}$. The results from these studies, the two previous and the present study, are similar and point into the direction of carbohydrates suppressing a protein stimulated $\mathrm{GH}$ response.

With respect to the role of fat intake as part of a meal, increasing plasma concentrations of free fatty acids (FFA), but not triglycerides, as a result of fat ingestion may also have been involved in the suppression of the $\mathrm{GH}$-promoting effect of soy protein during meal ingestion, since FFAs have suggested to suppress $\mathrm{GH}$-secretion ${ }^{13,14}$.

Fineberg et al. showed that $\mathrm{GH}$ release by protein ingestion can be inhibited but not completely abolished by increases of postprandial FFA concentrations ${ }^{14}$. These studies show that also alterations in FFA concentrations modified GH secretion. Together, all previous mentioned studies show that both plasma glucose and plasma FFA concentrations influence $\mathrm{GH}$ secretion. Therefore, the question remains which of the macronutrients are most responsible for interference with the protein-induced GH secretion. More research, with studies that only add either carbohydrates or fat to the protein being assessed is necessary.

Some studies suggest an effect of gastric emptying on hormonal release ${ }^{15,16}$. In this study, it is unlikely that gastric emptying has an influence on the reduced and delayed $\mathrm{GH}$-secretion after ingestion of a meal, compared with the soy proteindrink, since we showed in a previous study where we compared ingestion of an amino acid mixture with complete protein on $\mathrm{GH}$ secretion, that the rate of the appearance of plasma amino acids (AA) is not related to $\mathrm{GH}$ responses ${ }^{4}$

This study confirms previous findings that ingestion of dietary protein regulates $\mathrm{GH}$ secretion in the short-term. Moreover it also shows that the physiological role of food intake on the regulation of $\mathrm{GH}$ secretion involves complex interactions between the different macronutrients. Also in the long-term (after 7 days) low carbohydrate/ high protein diets increased IGF-1 concentrations and stimulated muscle protein synthesis and whole-body proteolysis ${ }^{7}$.

The clinical relevance of the results of this study however remains to be investigated. These results show that in normal healthy women, $\mathrm{GH}$ responses increase after oral ingestion of proteins, but not when proteins are combined with carbohydrates and fat. It is not known whether this effect also occurs in a GH-deficient population, such as in visceral obese subjects. In the visceral obese, $\mathrm{GH}$ replacement therapy reduced weight and in particular decreased fat mass and increased lean body mass ${ }^{17,18}$, more over it appeared that weight loss also restored $\mathrm{GH}$ concentrations to normal values ${ }^{19}$. It may be useful to explore the possibility of adding only one other macronutrient to soy protein in order to be able to design a diet that could stimulate $\mathrm{GH}$ secretion in such a population.

In conclusion, the short term somatotropic effect of soy protein is reduced and delayed if soy protein is ingested as part of a complete meal. Dietary carbohydrates, by increasing levels of glucose and insulin concentration, as well as free fatty acids may have interfered with the somatotropic effects of soy protein. 


\section{REFERENCES}

1. Veldhuis JD, Roemmich JN, Richmond EJ, Rogol AD, Lovejoy JC, Sheffield-Moore M, Mauras N \& Bowers CY. Endocrine control of body composition in infancy, childhood, and puberty. Endocr Rev 200526114 146.

2. Chromiak JA \& Antonio J. Use of amino acids as growth hormone-releasing agents by athletes. Nutrition 200218 657-661.

3. Knopf RF, Conn JW, Fajans SS, Floyd JC, Guntsche EM \& Rull JA. Plasma Growth Hormone Response To Intravenous Administration Of Amino Acids. J Clin Endocrinol Metab 196525 1140-1144.

4. van Vught JAH, Heitmann BL, Nieuwenhuizen AG, Veldhorst MAM, Brummer RJM \& WesterterpPlantenga MS. Association between dietary protein and 6y-change in body composition among normal and overweight 9y old boys and girls (EYHS) (in press). Clinical Nutrition 2008.

5. Rabinowitz D, Merimee TJ, Maffezzoli R \& Burgess JA. Patterns of hormonal release after glucose, protein, and glucose plus protein. Lancet 19662 454-456.

6. Baker HW, Best JB, Burger HG \& Cameron DP. Plasma human growth hormone levels in response to meals: a reappraisal. Aust J Exp Biol Med Sci 197250 715-724.

7. Harber MP, Schenk S, Barkan AL \& Horowitz JF. Effects of dietary carbohydrate restriction with high protein intake on protein metabolism and the somatotropic axis. J Clin Endocrinol Metab 2005905175 5181.

8. Merimee TJ, Pulkkinen AJ \& Burton CE. Diet-induced alterations of hGH secretion in man. J Clin Endocrinol Metab 197642 931-937.

9. Abumrad NN, Rabin D, Diamond MP \& Lacy WW. Use of a heated superficial hand vein as an alternative site for the measurement of amino acid concentrations and for the study of glucose and alanine kinetics in man. Metabolism 198130 936-940.

10. Pallotta JA \& Kennedy PJ. Response of plasma insulin and growth hormone to carbohydrate and protein feeding. Metabolism 196817 901-908.

11. Buijs MM, Burggraaf J, Langendonk JG, Schoemaker RC, Frolich M, Arndt JW, Cohen AF, Romijn JA, Ackermans MT, Sauerwein HP, Meinders AE \& Pijl H. Hyposomatotropism blunts lipolysis in abdominally obese women. J Clin Endocrinol Metab 200287 3851-3858.

12. Roth J, Glick SM, Yalow RS \& Bersonsa. Hypoglycemia: a potent stimulus to secretion of growth hormone. Science 1963140 987-988.

13. Blackard WG, Hull EW \& Lopez A. Effect of lipids on growth hormone secretion in humans. J Clin Invest 197150 1439-1443.

14. Fineberg SE, Horland AA \& Merimee TJ. Free fatty acid concentrations and growth hormone secretion in man. Metabolism 197221 491-498.

15. Gentilcore D, Chaikomin R, Jones KL, Russo A, Feinle-Bisset C, Wishart JM, Rayner CK \& Horowitz M. Effects of fat on gastric emptying of and the glycemic, insulin, and incretin responses to a carbohydrate meal in type 2 diabetes. J Clin Endocrinol Metab 200691 2062-2067.

16. Himaya A, Fantino M, Antoine JM, Brondel L \& Louis-Sylvestre J. Satiety power of dietary fat: a new appraisal. Am J Clin Nutr 199765 1410-1418.

17. Attallah H, Friedlander AL \& Hoffman AR. Visceral obesity, impaired glucose tolerance, metabolic syndrome, and growth hormone therapy. Growth Horm IGF Res 200616 Suppl A S62-67.

18. Pasarica M, Zachwieja JJ, Dejonge L, Redman S \& Smith SR. Effect of Growth Hormone on Body Composition and Visceral Adiposity in Middle Aged Men with Visceral Obesity. J Clin Endocrinol Metab 2007.

19. Rasmussen MH, Hvidberg A, Juul A, Main KM, Gotfredsen A, Skakkebaek NE, Hilsted J \& Skakkebae NE. Massive weight loss restores 24-hour growth hormone release profiles and serum insulin-like growth factor-I levels in obese subjects. J Clin Endocrinol Metab 199580 1407-1415. 


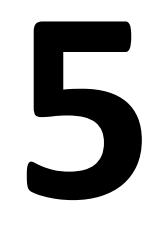

\section{Growth hormone responses to ingestion of soy protein with or without fat and/or carbohydrate in humans}

ANNEKE J.A.H. VAN VUGHT, ARIE G. NIEUWENHUIZEN, MARGRIET A.B. VELDHORST, ROBERT-JAN M. BRUMMER, MARGRIET S. WESTERTERP-PLANTENGA

E-SPEN JOURNAL, 2009 IN PRESS 


\section{ABSTRACT}

Background \& Aim: Growth hormone $(\mathrm{GH})$ is an important regulator of growth and body-composition. It has been shown that $\mathrm{GH}$-release can be promoted by administration of various amino acids, such as arginine and lysine, that are present in soy protein. Soy protein ingestion increases $\mathrm{GH}$-secretion more than ingestion of a combination of arginine and lysine. The GH promoting effect of soy protein however is not present when soy protein is ingested combined with carbohydrate and fat. The aim of this study is to investigate whether carbohydrate or fat eliminates the GH-promoting effect of soy protein.

Methods: We compared ingestion of soy protein plus carbohydrate (soy+carbohydrate) or soy protein plus fat (soy+fat) with ingestion of soy protein alone(soy), soy protein plus carbohydrate plus fat (soy+carbohydrate+fat) and a placebo. The study was performed in eight healthy women (age: $21 \pm 1.5$ years, body mass index (BMI): $22 \pm 1.8 \mathrm{~kg} / \mathrm{m}^{2}$ ) in a randomized, single blind, placebocontrolled crossover design. GH-, insulin-, glucose- and AA-concentrations were measured during $5 \mathrm{~h}$.

Results: Ingestion of soy+carbohydrate or soy+fat stimulated GH-responses to the same extent than soy (incremental area under the curve (IAUC); $374 \pm 50 \mu \mathrm{g} / \mathrm{L} .5 \mathrm{~h}$, $400 \pm 57 \mu \mathrm{g} / \mathrm{L} .5 \mathrm{~h}, 403 \pm 73 \mu \mathrm{g} / \mathrm{L} .5 \mathrm{~h}$ respectively), but more than after ingestion of soy+carbohydrate+fat or placebo (IAUC; $226 \pm 43 \mu \mathrm{g} / \mathrm{L} .5 \mathrm{~h}, 84 \pm 52 \mu \mathrm{g} / \mathrm{L} .5 \mathrm{~h}$ respectively) ( $p<0.05)$. Insulin responses were higher after ingestion of soy+carbohydrate or soy+carbohydrate+fat, than after soy+fat or soy $(p<0.05)$. Compared with placebo, all conditions showed higher insulin concentrations $(p<0.05)$. Glucose responses were higher after ingestion of soy+carbohydrate than after the other conditions $(p<0.05)$. Peak plasma arginine-concentrations were higher after ingestion of soy compared with soy+carbohydrate+fat $(p<0.05)$.

Conclusion: The GH promoting activity of soy protein depends on the macronutrient composition, in that, fat and carbohydrate should not be present at the same time. Serum arginine concentrations may be involved in the somatotropic activity of protein. Glucose and insulin responses however are not involved. 


\section{INTRODUCTION}

Growth hormone $(\mathrm{GH})$, a hormone originating from the anterior pituitary gland, is an important regulator of growth and body composition and exerts its growthpromoting effect through stimulation of the secretion of Insulin-Like Growth Factor I (IGF-I) ${ }^{1,2}$. Furthermore, GH has several metabolic effects, the most important one is an elevation of FFA by stimulation of the lipolysis ${ }^{3,4}$, which could lead to the switching substrate metabolism from glucose and protein utilisation to lipid oxidation ${ }^{2,5}$. With respect to glucose metabolism, increased GH concentrations decrease glucose oxidation and there is evidence that gluconeogenesis is stimulated by increased $\mathrm{GH}$ concentrations ${ }^{2,6}$. The effects of $\mathrm{GH}$ on protein metabolism in basal state (i.e. after an overnight fast) are not unambiguous and perhaps of minor biological significance, however in stress states and pathological states, GH suggest anabolic actions, which may include increased protein synthesis and decreased breakdown at the whole body level ${ }^{2,7}$.

The effects of GH secretion on fat, glucose and protein metabolism are recognized. On the other hand, there is also evidence that several macronutrients influence the $\mathrm{GH}$ secretion.

It has been shown by many authors that GH secretion can be promoted by intravenous or oral administration of various amino acids, either alone or combined ${ }^{8,9}$. The stimulatory effect of amino acids on GH secretion is also present when the amino acids are ingested as a protein. Our previous study showed that GH secretion was similar after ingestion of an amino acid mixture or after ingestion of soy protein, with comparable amino acid content ${ }^{10}$. However, the GH promoting effect of soy protein was reduced and delayed when soy protein was ingested as part of a meal, containing protein, carbohydrate and fat ${ }^{11}$. This may indicate that not only soy protein, but also carbohydrate and/or fat plays an important modulating role in the postprandial secretion of $\mathrm{GH}$ after ingestion of a high-protein meal.

Studies investigating the somatotropic effects of macronutrients have shown various results. Infusion or intake of glucose or carbohydrate resulted in reduced $\mathrm{GH}$ concentrations over a short-term period (2-3h), followed by increased $\mathrm{GH}$ concentrations after 3-5 $\mathrm{h}^{12-16}$. One study found that $\mathrm{GH}$ responses at $60 \mathrm{~min}$ and $120 \mathrm{~min}$ after the intake of glucose combined with protein were not different compared with ingestion of glucose alone ${ }^{17}$, while other studies found that $\mathrm{GH}$ responses were lower after the intake of carbohydrate combined with protein, than after intake of carbohydrate or protein alone ${ }^{15,16}$. The rebound rise of $\mathrm{GH}$ after glucose administration is probably related to the amount of glucose given ${ }^{18}$. With respect to the role of lipids, lipid infusion suppresses GH secretion ${ }^{19}, 20$, even as lipid ingestion combined with heparin injection ${ }^{21}$, however no suppression of $\mathrm{GH}$ secretion is found when lipids, without heparin are ingested ${ }^{21}$. Also two other studies found that fat did not alter GH concentrations after an arginine stimulus ${ }^{22}$, 
23. Furthermore, controversial results of lipid administration on exercise induced $\mathrm{GH}$ release were found, while Hunter et al found no suppression of the exercise induced $\mathrm{GH}$ release after ingestion of fat, Cappon et al found a reduced exerciseinduced $\mathrm{GH}$ release after ingestion of fat compared with placebo or carbohydrate intake before exercise ${ }^{24}$.

Taken together, previous studies showed an increase in GH secretion after ingestion of protein, however, this GH promoting effect of protein is eliminated when combined with carbohydrate and fat. Equivocal effects of carbohydrates and fat on GH secretion were found, therefore, the aim of this study is to investigate whether carbohydrate or fat or a combination is responsible for interference with the protein-induced $\mathrm{GH}$ secretion when protein is ingested combined with carbohydrates and fat. Ingestion of protein alone, combined with either carbohydrate or fat and protein combined with carbohydrate and fat are compared.

\section{METHODS}

\section{Subjects}

Subjects were recruited via advertisements at the university. They underwent a screening procedure including medical history taking, measurement of bodyweight and height. Eight females were selected on the basis of being in good health, nonsmoker, non-vegetarian, using oral contraceptives, not using other medication, not spending more than three hours sport activities a week and at most moderate alcohol users ( $<10$ alcoholic consumptions per week). Only females were included, because in previous studies was found that females responded more consistently and with a greater increase in $\mathrm{GH}$ after ingestion of certain amino acids than men ${ }^{25,26}$. Their mean age was $21 \pm 1.5$ years, and their body mass index (BMI) was $22 \pm$ $1.8 \mathrm{~kg} / \mathrm{m}^{2}$. All tests were performed in the early follicular phase of each woman's menstrual cycle, to eliminate the confounding variable of changing serum estrogen concentrations. The Medical Ethics Committee of Maastricht University approved the study protocol and all subjects gave their written informed consent before participating in the study.

\section{Experimental design}

A randomized crossover study design was applied. Subjects reported to the laboratory for consumption of five different test drinks, separated by at least one week. Each time, subjects arrived at the laboratory in a fasted state, at $8.30 \mathrm{~h}$. They were instructed to fast from $10 \mathrm{pm}$ the night prior to the test day. A canula was placed into a dorsal hand vein of the contra lateral arm, and this hand was kept in a 
thermoregulated $\left(60^{\circ} \mathrm{C}\right)$ box to sample arterialized venous blood ${ }^{27}$. Blood sampling began 60 min after placement of the canula $(t=0)$. Blood samples for determination of $\mathrm{GH}$ were obtained before and every $20 \mathrm{~min}$ for 5 hours after ingestion of the testdrinks, blood samples for determination of glucose and insulin were obtained before and 40,60,180 and 300 min after the intake of the testdrinks.

Blood samples for determination of amino acids were obtained before and 60, 80, 100, 180 and 300 min after intake of the testdrinks. During blood sampling, subjects remained awake and fasted and were allowed to drink water ad libitum. Immediately after obtaining the first blood sample $(\mathrm{t}=0)$, subjects received a test drink and had to be finished in 5 minutes. Subjects received a drink containing soy protein (Supro ${ }^{\circledR}$ 590, The Solae Company, St. Louis, MO, United States of America), soy protein plus carbohydrate (soy+carbohydrate), soy protein plus fat (soy+fat), soy protein plus carbohydrate plus fat (soy+carbohydrate+fat) and a placebo, which contained only water. Carbohydrate used in the testdrink was tapioca-starch (Farinex VA50T, AVEBE, Veendam, The Netherlands and Perfectamyl 3108 AVEBE, Veendam, The Netherlands), fat used was sunflower-oil (Reddy, NV Vandemoortele, Roosendaal, The Netherlands). The sugarfree syrup (Diaran, Cereal) added to improve the taste of the drinks, contained no protein and fat and a negligible amount of carbohydrate. Since the objective of this study was to investigate whether the carbohydrate or the fat part of a (high protein) diet is responsible for the elimination of the $\mathrm{GH}$ response to soy protein, the macronutrient amount of the test drinks was kept constant, resulting in a different energy content. The viscosity of the testdrinks was equal. The composition of the test drinks is described in Table 1.

Table 1: Composition of the tests conditions, based on a subject of $70 \mathrm{~kg}$.

\begin{tabular}{cccccc}
\hline & Soy & Soy+CH & Soy+Fat & Soy+CH+Fat & Placebo \\
\hline Volume $(\mathrm{ml})$ & 450 & 450 & 450 & 450 & 450 \\
Soy protein $(\mathrm{g})$ & 42 & 42 & 42 & 42 & - \\
Carbohydrate $(\mathrm{CH})(\mathrm{g})$ & - & 92 & - & 92 & - \\
Fat $(\mathrm{g})$ & - & - & 15 & 15 & - \\
Sugar free syrup $(\mathrm{ml})$ & 40 & 40 & 40 & 40 & 40 \\
\hline
\end{tabular}

\section{Blood analyses}

Arterialized venous blood was collected in clot tubes, containing 'Silica Clot Activator' (Becton Dickinson Vacutainer system; Becton Dickinson, Franklin Lakes, NJ), and in heparinized tubes (Becton Dickinson Vacutainer system; Becton Dickinson, Franklin Lakes, NJ). Blood in the clot tubes was allowed to clot for 30 minutes and was centrifuged at $3000 \mathrm{rpm}, 4^{\circ} \mathrm{C}$ for $10 \mathrm{~min}$ to obtain serum. Serum was collected 
for determination of $\mathrm{GH}$ and amino acid (AA) concentrations. Blood in heparinized tubes was kept on ice to minimize enzymatic reactions. Glucose and insulin analyses were performed in plasma, which was obtained by centrifugation at $4^{\circ} \mathrm{C}$ for 10 min at $3000 \mathrm{rpm}$. Each aliquot was frozen immediately in liquid nitrogen and stored at $-80^{\circ} \mathrm{C}$, until analysis. All samples from the same subject were analysed in the same assay.

The GH-concentrations were measured by using an ultrasensitive $\mathrm{GH}$ chemiluminescence immunoassay (Beckman Coulter, Harbor Blvd. Fullerton, U.S.A.). The intra- and inter-assay coefficients of variation were $1.4-2.1$ and $6.8-8.6 \%$ respectively, at $\mathrm{GH}$ concentrations of 3.7-14.2 and 3.1-7.3 $\mathrm{\mu g} / \mathrm{l}$, respectively. Insulin concentrations were measured by an electrochemiluminescence immunoassay (ELICA) (Roche Diagnostica, Hoffman-La Roche, Basel, Switzerland). Glucose concentrations were measured by using enzymatic assay (G6-PDH) (Roche Diagnostica, Hoffman-La Roche, Basel, Switzerland). The concentrations of the amino acids; arginine, lysine, histidine, methionine, ornithine, phenylalanine and glutamic acid were measured using a HPLC system (Shimadzu, Duisburg, Germany).

\section{Statistics}

Data are presented as mean changes from baseline +/- standard error to the mean (SEM). Baseline ratings for $\mathrm{GH}$, insulin, glucose and AAs were not statistically significantly different among treatments, therefore delta concentrations were used for statistical analysis. Growth hormone, insulin, glucose and AA responses were calculated as incremental area under the curve (IAUC), peak values and time to peak (TTP) values. IAUC is defined as the total AUC minus the baseline AUC. Peak values were defined as the highest mean value obtained within $300 \mathrm{~min}$. Statistical analyses of the data were performed using repeated measures analysis of variance (ANOVA), correcting for multiple analyses. Post hoc comparisons were made with the Fisher PLSD-test. A p-value $<0.05$ was regarded as statistically significant. All statistical tests were performed by using Statview SE Graphics software (version 4.5; Abacus Concepts Inc, Berkeley, CA, USA).

\section{RESULTS}

$\mathrm{GH}$-responses as determined by incremental area under the curve (IAUC) over $5 \mathrm{~h}$ were higher after ingestion of soy alone, soy+carbohydrate or soy+fat, than after ingestion of soy+carbohydrate+fat or placebo $(p<0.05)$ (Figure 1, Table 2). GH peak values after ingestion of soy alone, soy+carbohydrate or soy+fat were higher compared with ingestion of soy+carbohydrate+fat or placebo $(p<0.05)$ (Figure 1, Table 2). GH peak values after ingestion of soy alone or soy+fat were higher com- 
pared with soy+carbohydrate+fat. No difference in GH-response, AUC and peakvalues, was found between ingestion of soy+carbohydrate+fat and placebo (Figure 1, Table 2). Time to peak values (TTP) were later after ingestion of soy+carbohydrate+fat or soy+fat than after ingestion of soy $(p<0.05)$ and TTP was later after ingestion of the placebo than after ingestion of soy $(p<0.05)$ (Figure 1 , Table 2).

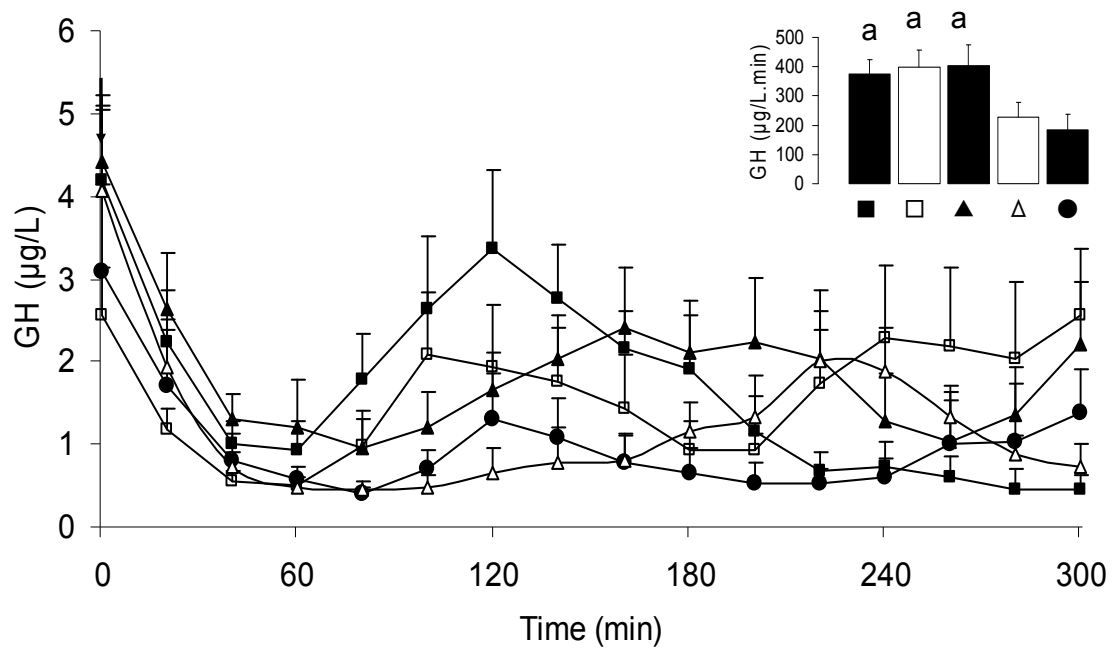

Figure 1: Growth hormone concentrations after ingestion of a placebo $(\bullet)$, soy protein ( $\square$ ), soy protein+carbohydrate $(\square)$, soy protein+fat $(\boldsymbol{\Delta})$ and soy protein+carbohydrate+fat $(\Delta)(n=8)$. Data are presented as mean ( \pm SEM) in lines and bars (IAUC). $\downarrow=$ ingestion of testdrink. Peak values of GH were higher after ingestion of soy, soy+carbohydrate and soy+fat, compared with soy+carbohydrate+fat and placebo. $a=p<0.05$ compared with placebo and soy protein+carbohydrate + fat.

Insulin responses as determined by IAUC and peak values were higher after ingestion of soy or combined with either carbohydrate or fat, soy alone or soy+carbohydrate+fat than after ingestion of placebo $(p<0.05)$. Ingestion of soy+carbohydrate and soy+carbohydrate+fat showed higher insulin responses (AUC and peak), compared with insulin responses after ingestion of soy+fat or soy alone. TTP of insulin was not significant different between the conditions (Figure 2, Table 2).

Glucose responses as determined by IAUC were higher after ingestion of soy + carbohydrate than after ingestion of soy + fat, soy + fat + carbohydrate, soy alone or placebo $(p<0.05)$ (Figure 3, Table 2). Glucose peak concentration after ingestion of soy + carbohydrate was higher compared with soy + fat or placebo while glucose peak concentrations for soy + carbohydrate + fat were higher compared with ingestion of soy alone, soy + fat or placebo $(p<0.05)$ (Table 2$)$. TTP of glucose was not significant different between the conditions (Table 2). 
With respect to serum AA-concentrations; AA-concentrations, determined as IAUC were not different between the testdrinks, soy alone, soy+carbohydrate, soy+fat and soy+carbohydrate+fat. Peak-concentrations of arginine, lysine, histidine, methionine, ornithine, and phenylalanine were higher after ingestion of soy compared with soy+carbohydrate+fat $(p<0.05)$. Lysine, histidine, methionine, ornithine and phenylalanine concentrations were higher after ingestion of soy compared with soy+carbohydrate and soy+fat $(p<0.05)$. Arginine concentrations were not different after intake of soy, soy+carbohydrate and soy+fat, but were higher compared with arginine concentrations after intake of soy+carbohydrate+fat $(p<0.001)$. The time to peak of the AA-concentrations was not different after the ingestion of soy, soy+carbohydrate, soy+fat or soy+carbohydrate+fat. At 300 min after ingestion of the testdrinks, arginine, lysine and histidine concentrations were higher after ingestion of soy+carbohydrate than after ingestion of soy (Figure 4, Table 2).

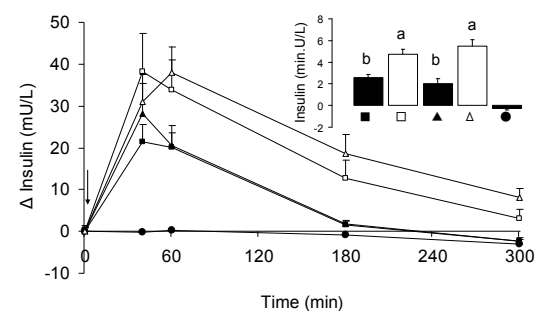

Figure 2: Delta insulin concentrations after ingestion of a placebo $(\bullet)$, soyprotein soyprotein+carbohydrate $(\square)$, soyprotein+fat $(\boldsymbol{\Delta})$ and soyprotein+carbohydrate+fat $(\Delta) \quad(n=8)$. Data are presented as means ( \pm SEM) in lines and bars (IAUC). $\downarrow=$ ingestion of testdrink. Peak concentrations of insulin are significant higher after ingestion of soy+carbohydrate and soy+carbohydrate+fat compared with soyprotein, soyprotein + fat and placebo. Insulin concentrations after ingestion of placebo are significant lower than after the other testdrinkes. $a=p<0.05$ compared with soyprotein, soyprotein+fat and placebo. $b=p<0.05$ compared with placebo

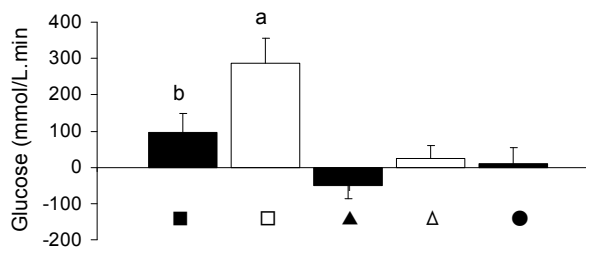

Figure 3: Glucose concentrations after ingestion of a placebo $(\bullet)$, soy protein $(\mathbf{\square})$, soy protein+carbohydrate $(\square)$, soy protein+fat $(\boldsymbol{\Delta})$ and soy protein+carbohydrate+fat $(\Delta) \quad(n=8)$. Data are presented as AUC over 5h. $\downarrow=$ ingestion of testdrink. $a=p<0.05$ compared with soy protein, soy protein+fat, soy protein+carbohydrate+fat and placebo, $b=p<0.05$ compared with soyprotein $+f a t$. 


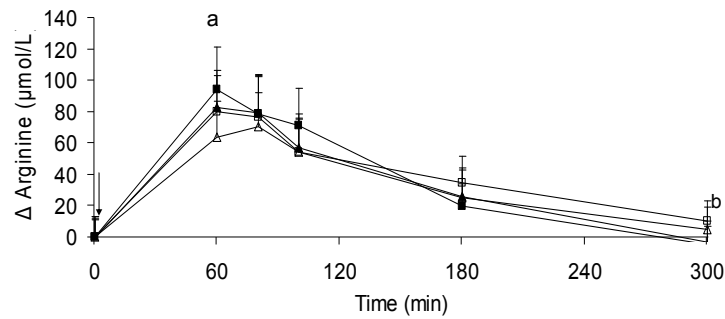

Figure 4: Delta arginine concentrations (ARG) after ingestion of soyprotein ( $\mathbf{\square}$ ), soyprotein+carbohydrate $(\square)$, soyprotein+fat $(\boldsymbol{\Delta})$ and soyprotein+carbohydrate+fat $(\Delta)(n=8)$. Data are presented as means ( \pm SEM) in lines. $\downarrow=$ ingestion of testdrink. a = ARG concentrations at $60 \mathrm{~min}$ are higher after ingestion of soy, soy+carbohydrate and soy+fat compared with soy+carbohydrate+fat $(p<0.001), b=$ Arginine-concentrations are higher at $300 \mathrm{~min}$ after ingestion of soy+carbohydrate than after ingestion of soy $(p<0.05)$.

Table 2: Blood parameters after ingestion of a placebo, soy protein, soy protein+carbohydrate, soy protein+fat and soy protein+carbohydrate+fat $(n=8)$, expressed as incremental area under the curve (IAUC), peak-values and time to peak (TTP). Data are presented as mean ( \pm SEM).

\begin{tabular}{|c|c|c|c|c|c|c|c|c|c|c|c|c|c|c|c|}
\hline \multirow[b]{3}{*}{$\mathrm{GH}(\min . \mu \mathrm{g} / \mathrm{L})$} & \multicolumn{15}{|c|}{ IAUC } \\
\hline & \multicolumn{3}{|c|}{ Placebo } & \multicolumn{3}{|c|}{ Soy } & \multicolumn{3}{|c|}{ Soy+Carbohydrate } & \multicolumn{3}{|c|}{ Soy+Fat } & \multicolumn{3}{|c|}{ Soy+Carbohydrate+Fat } \\
\hline & 184.04 & \pm & 52.10 & 373.99 & \pm & $49.56^{3.6}$ & 399.03 & \pm & $57.11^{2.6}$ & 402.96 & \pm & $72.62^{2.6}$ & 225.93 & \pm & 43.00 \\
\hline Insulin (min.U/L) & -0.26 & \pm & 0.17 & 2.60 & \pm & $0.25^{\mathrm{a}}$ & 4.74 & \pm & $0.44^{\text {ad.e }}$ & 2.03 & \pm & $0.48^{\mathrm{a}}$ & 5.46 & \pm & $0.63^{\text {ad.e }}$ \\
\hline Glucose (min.mmol/L) & 8.66 & \pm & 46.51 & 96.36 & \pm & $51.57^{d}$ & 285.45 & \pm & $69.51^{\text {ab.d.e }}$ & -50.16 & \pm & 37.77 & 74.55 & \pm & 44.38 \\
\hline Arginine (min.mmol/l) & & & & 10.58 & \pm & 1.72 & 12.73 & \pm & 1.89 & 10.25 & \pm & 1.18 & 10.64 & \pm & 2.19 \\
\hline Lysine (min.mmol/l) & & & & 23.73 & \pm & 3.54 & 21.82 & \pm & 2.67 & 16.42 & \pm & 1.44 & 17.56 & \pm & 3.40 \\
\hline Histidine (min.mmol/l) & & & & 5.34 & \pm & 1.52 & 4.80 & \pm & 1.16 & 2.55 & \pm & 0.78 & 3.31 & \pm & 1.81 \\
\hline Methionine (min.mmol/l) & & & & 1.04 & \pm & 0.31 & 0.59 & \pm & 0.30 & 0.26 & \pm & 0.22 & 0.30 & \pm & 0.54 \\
\hline Ornithine (min.mmol/l) & & & & 7.85 & \pm & 1.05 & 5.89 & \pm & 0.93 & 15.24 & \pm & 9.24 & 5.07 & \pm & 1.28 \\
\hline Phenylalanine (min.mmol/l) & & & & 7.55 & \pm & 1.04 & 6.61 & \pm & 0.70 & 6.60 & \pm & 0.46 & 6.37 & \pm & 1.04 \\
\hline Glutamic acid (min.mmol/l) & & & & 0.16 & \pm & 2.26 & -2.52 & \pm & 0.90 & -2.19 & \pm & 1.22 & -1.89 & \pm & 1.69 \\
\hline
\end{tabular}

\begin{tabular}{|c|c|c|c|c|c|c|c|c|c|c|c|c|c|c|c|}
\hline \multirow[b]{3}{*}{ GH $(\mu \mathrm{g} / \mathrm{L})$} & \multicolumn{15}{|c|}{ Peak } \\
\hline & \multicolumn{3}{|c|}{ Placebo } & \multicolumn{3}{|c|}{ Soy } & \multicolumn{3}{|c|}{ Soy+Carbohydrate } & \multicolumn{3}{|c|}{ Soy+Fat } & \multicolumn{3}{|c|}{ Soy+Carbohydrate+Fat } \\
\hline & 2.19 & \pm & 0.77 & 4.99 & \pm & $0.81^{2.6}$ & 4.87 & \pm & $0.88^{2.6}$ & 4.19 & \pm & $0.68^{2.5}$ & 3.00 & \pm & 0.56 \\
\hline Insulin (mU/L) & 8.50 & \pm & 1.07 & 32.10 & \pm & $7.65^{\mathrm{a}}$ & 51.53 & \pm & $9.14^{\text {ade }}$ & 33.84 & \pm & $6.84^{3}$ & 44.81 & \pm & $6.51^{\text {adde }}$ \\
\hline Glucose $(\mu \mathrm{mol} / \mathrm{L})$ & 5.30 & \pm & 0.14 & 5.50 & \pm & 0.10 & 5.84 & \pm & $0.13^{2 d}$ & 5.26 & \pm & 0.22 & 5.95 & \pm & $0.13^{\text {ad.e }}$ \\
\hline Arginine $(\mu \mathrm{mol} / \mathrm{I})$ & & & & 204.50 & \pm & $11.45^{\mathrm{b}}$ & 204.50 & \pm & $12.17^{\mathrm{b}}$ & 202.98 & \pm & $8.73^{\mathrm{b}}$ & 141.88 & \pm & 6.99 \\
\hline Lysine ( $\mu \mathrm{mol} / \mathrm{l})$ & & & & 354.38 & \pm & $9.32^{b, c . c d}$ & 313.00 & \pm & 26.23 & 310.13 & \pm & 18.62 & 299.25 & \pm & 29.05 \\
\hline Histidine ( $\mu \mathrm{mol} / \mathrm{l})$ & & & & 138.38 & \pm & $7.92^{\mathrm{b} . c \mathrm{~d}}$ & 130.50 & \pm & 6.38 & 124.50 & \pm & 14.98 & 123.13 & \pm & 5.13 \\
\hline Methionine $(\mu \mathrm{mol} / \mathrm{ll})$ & & & & 39.25 & \pm & $1.99^{\text {becd }}$ & 33.63 & \pm & 1.82 & 36.63 & \pm & 1.96 & 34.88 & \pm & 2.99 \\
\hline Ornithine ( $\mu$ mol/l) & & & & 110.15 & \pm & $7.03^{\text {b.c.d }}$ & 99.00 & \pm & 5.47 & 104.75 & \pm & 4.60 & 100.75 & \pm & 9.41 \\
\hline Phenylalanine $(\mu \mathrm{mol} / \mathrm{l})$ & & & & 125.13 & \pm & $7.47^{b . c . d}$ & 115.00 & \pm & 5.23 & 119.00 & \pm & 2.81 & 108.88 & \pm & 5.19 \\
\hline Glutamic acid $(\mu \mathrm{mol} / \mathrm{l})$ & & & & 124.88 & \pm & 7.89 & 127.00 & \pm & 9.25 & 136.88 & \pm & 9.67 & 134.75 & \pm & 14.61 \\
\hline
\end{tabular}

\begin{tabular}{|c|c|c|c|c|c|c|c|c|c|c|c|c|c|c|c|}
\hline \multirow[b]{3}{*}{$\mathrm{GH}(\mathrm{min})$} & \multicolumn{15}{|c|}{ TTP } \\
\hline & \multicolumn{3}{|c|}{ Placebo } & \multicolumn{3}{|c|}{ Soy } & \multicolumn{3}{|c|}{ Soy+Carbohydrate } & \multicolumn{3}{|c|}{ Soy+Fat } & \multicolumn{3}{|c|}{ Soy+Carbohydrate+Fat } \\
\hline & 180 & \pm & $30^{\circ}$ & 123 & \pm & 11.60 & 168 & \pm & 25 & 140 & \pm & 14.20 & 193 & \pm & $21^{\text {dee }}$ \\
\hline Insulin (min) & 37 & \pm & 8 & 30 & \pm & 2 & 29 & \pm & 4 & 26 & \pm & 3 & 34 & \pm & 3 \\
\hline Glucose (min) & 33 & \pm & 9 & 43 & \pm & 6 & 50 & \pm & 8 & 43 & \pm & 9 & 48 & \pm & 9 \\
\hline Arginine (min) & & & & 55 & \pm & 6 & 50 & \pm & 5 & 48 & \pm & 4 & 53 & \pm & 4 \\
\hline Lysine (min) & & & & 60 & \pm & 7 & 45 & \pm & 3 & 50 & \pm & 4 & 50 & \pm & 4 \\
\hline Histidine (min) & & & & 65 & \pm & 6 & 48 & \pm & 4 & 58 & \pm & 6 & 58 & \pm & 6 \\
\hline Methionine (min) & & & & 55 & \pm & 6 & 43 & \pm & 3 & 45 & \pm & 3 & 48 & \pm & 4 \\
\hline Ornithine (min) & & & & 63 & \pm & 7 & 50 & \pm & 5 & 48 & \pm & 4 & 55 & \pm & 5 \\
\hline Phenylalanine ( $\mathrm{min}$ ) & & & & 65 & \pm & 6 & 53 & \pm & 5 & 53 & \pm & 4 & 53 & \pm & 4 \\
\hline Glutamic acid (min) & & & & 63 & \pm & 7 & 50 & \pm & 5 & 48 & \pm & 4 & 58 & \pm & 5 \\
\hline
\end{tabular}




\section{DISCUSSION}

This study shows that the somatotropic effect of soy protein was reduced by simultaneous co-ingestion of carbohydrate and fat, but not by co-ingestion of either carbohydrate or fat.

As mentioned in the introduction, carbohydrate as well as fat could interfere with protein's effect on GH secretion. Several studies, but not all ${ }^{17}$ found that carbohydrate ingestion alone increased the $\mathrm{GH}$ concentrations 3-5 h after ingestion ${ }^{12-16}$, and that fat ingestion did not change the $\mathrm{GH}$ response, however when heparin was injected combined with fat ingestion, $\mathrm{GH}$ concentrations were reduced, due to increased FFA concentrations ${ }^{21,23}$. Still only a few studies compared the GH responses after co-ingestion of carbohydrate or fat with protein ${ }^{15,16}$ as we did in our study.

Two studies aimed to compare effects of protein or protein plus carbohydrate on $\mathrm{GH}$ response. They found a decreased $\mathrm{GH}$ response after ingestion of protein combined with carbohydrate compared with protein alone. The protein source used however contained also small amounts of fat ${ }^{15,16}$, and is therefore comparable with our test condition protein+fat. Hence, this confirms our results in which we found a reduced $\mathrm{GH}$ response when protein+carbohydrate+fat was ingested compared with protein+fat ${ }^{15,16}$.

To our knowledge, no further studies were performed comparing the ingestion of protein alone with protein plus carbohydrates. As we mentioned above, carbohydrate ingestion increases the $\mathrm{GH}$ response 3-5 $\mathrm{h}$ after ingestion ${ }^{12-16}$. In our results we found two $\mathrm{GH}$ peaks after ingestion of protein plus carbohydrates (Figure 1). The first peak may be a result of the protein induced $\mathrm{GH}$ secretion, as we also found after ingestion of protein alone. The second peak was not found after ingestion of protein alone, and must therefore be attributed to the simultaneous presence of carbohydrate. This could have resulted in changes in protein metabolism, as AA concentrations were higher at $\mathbf{3 0 0}$ minutes after ingestion of carbohydrate plus proteins, when compared with protein alone. These higher AA concentrations may, in turn, be involved in the increase of GH concentrations.

With respect to the role of fat combined with protein, we found that fat delays the $\mathrm{GH}$ response to protein, but the GH-AUC and GH-peak values after ingestion of protein plus fat were not different from that of protein alone, which is also observed in two studies, reporting that cornoil ingestion did not change GH concentrations. The delayed $\mathrm{GH}$ peak after ingestion of the test drinks containing fat compared with soy alone can not be clarified by insulin-, glucose- or AAconcentrations. Fat is known to delay gastric emptying, however this mechanism does not seems to be involved in the delayed $\mathrm{GH}$ response, since we did not find a delayed or lower insulin peak concentration, neither a delayed AA peak compared with ingestion of soy alone. A mechanism explaining the delayed $\mathrm{GH}$ peak after 
ingestion of fat, may be a direct effect of fat on somatostatin which could delay the $\mathrm{GH}$ response after ingestion of the test conditions containing fat ${ }^{28,29}$.

The GH promoting effect of protein is still present when ingested combined with either carbohydrate or fat, but not when combined with carbohydrate and fat. The underlying mechanism of the eliminated $\mathrm{GH}$ promoting effect of soy after ingestion of soy combined with carbohydrate and fat remains unclear.

In line with our objective, the macronutrient amount of the testdrinks was kept constant, which resulted in different caloric contents of the testdrinks. We cannot rule out the possibility that the different energy content of the testdrinks affected the $\mathrm{GH}$ response, although a major role of energy content is not very likely, since no differences in AUC GH and PEAK GH responses were found between the ingestion of soy, soy+carbohydrate and soy+fat.

Insulin as well as glucose concentrations were higher after ingestion of soy combined with carbohydrate compared with soy alone, however $\mathrm{GH}$ concentrations (AUC) did not differ between the conditions, indicating that neither insulin nor glucose itself was instrumental in the decreased $\mathrm{GH}$ response after soy+carbohydrate+fat.

Amino acids that are known to stimulate the $\mathrm{GH}$ response are in particular arginine, but also lysine, histidine, ornithine, methionine, phenylalanine and glutamic acid ${ }^{8,}$ 9, 30 . We found lower peak serum AA concentrations of arginine, lysine, histidine, ornithine, methionine and phenylalanine after ingestion of soy+carbohydrate+fat than after soy alone, which could explain the reduced somatotropic effect of soy protein after co-ingestion with carbohydrate and fat. Despite no differences in $\mathrm{GH}$ responses after ingestion of soy+carbohydrate, soy+fat and soy alone, serum concentrations of lysine, histidine, ornithine, methionine and phenylalanine were lower after ingestion of soy+carbohydrate or soy+fat compared with soy alone. This indicates that peak arginine, but not the other amino acids, may be involved in the reduced somatotropic effect of protein after co-ingestion with carbohydrate and fat. To provide more direct evidence that arginine is responsible for the reduced somatotropic effects, soy+carbohydrate+fat plus an arginine supplement could be tested.

Furthermore increased FFA concentrations are known to suppress the GH secretion. In this study we did not measure FFA concentrations, however we do not think that our results are explained by changing FFA concentrations, since increased insulin concentrations, known to suppress the lipolysis, were not different between soy+carborhydrate and soy+carbohydrate+fat. GH responses however were reduced after ingestion of soy+carbohydrate+fat, but not after soy+carbohydrate, compared with soy alone.

This study confirms previous findings that ingestion of dietary protein regulates $\mathrm{GH}$ secretion in the short-term. Moreover it also shows that the physiological role of food intake on the regulation of $\mathrm{GH}$ secretion involves complex interactions when 
the different macronutrients are ingested together. Thus, the GH-promoting activity of soy protein depends on the presence of other macronutrients, in that fat and carbohydrate should not be present at the same time. Serum arginine concentrations may be involved in the somatotropic activity of protein, glucose and insulin responses however are not responsible for this effect. 


\section{REFERENCES}

1. Veldhuis JD, Roemmich JN, Richmond EJ, Rogol AD, Lovejoy JC, Sheffield-Moore M, Mauras N \& Bowers CY. Endocrine control of body composition in infancy, childhood, and puberty. Endocr Rev 200526114 146.

2. Moller N \& Jorgensen JO. Effects of Growth Hormone on Glucose, Lipid and Protein Metabolism in Human Subjects. Endocr Rev 2009.

3. Gravholt CH, Schmitz O, Simonsen L, Bulow J, Christiansen JS \& Moller N. Effects of a physiological GH pulse on interstitial glycerol in abdominal and femoral adipose tissue. Am J Physiol 1999277 E848-854.

4. Moller N, Jorgensen JO, Schmitz O, Moller J, Christiansen J, Alberti KG \& Orskov H. Effects of a growth hormone pulse on total and forearm substrate fluxes in humans. Am J Physiol 1990258 E86-91.

5. Rabinowitz D \& Zierler KL. A Metabolic Regulating Device Based on the Actions of Human Growth Hormone and of Insulin, Singly and Together, on the Human Forearm. Nature 1963199 913-915.

6. Butler P, Kryshak E \& Rizza R. Mechanism of growth hormone-induced postprandial carbohydrate intolerance in humans. Am J Physiol 1991260 E513-520.

7. Fryburg DA, Gelfand RA \& Barrett EJ. Growth hormone acutely stimulates forearm muscle protein synthesis in normal humans. Am J Physiol 1991260 E499-504.

8. Chromiak JA \& Antonio J. Use of amino acids as growth hormone-releasing agents by athletes. Nutrition 200218 657-661.

9. Knopf RF, Conn JW, Fajans SS, Floyd JC, Guntsche EM \& Rull JA. Plasma Growth Hormone Response to Intravenous Administration of Amino Acids. J Clin Endocrinol Metab 196525 1140-1144.

10. van Vught JAH, Heitmann BL, Nieuwenhuizen AG, Veldhorst MAM, Brummer RJM \& WesterterpPlantenga MS. Association between dietary protein and 6y-change in body composition among normal and overweight 9y old boys and girls (EYHS) (in press). Clinical Nutrition 2008.

11. van Vught AJ, Nieuwenhuizen AG, Brummer RJ \& Westerterp-Plantenga MS. Somatotropic responses to soy protein alone and as part of a meal. Eur J Endocrinol 2008159 15-18.

12. Bernardi F, Petraglia F, Seppala M, Spinetti A, Bertolini S, Driul L, Ferdeghini M \& Genazzani AR. GH, IGFBP-1, and IGFBP-3 response to oral glucose tolerance test in perimenopausal women: no influence of body mass index. Maturitas 199933 163-169.

13. Frystyk J, Grofte T, Skjaerbaek C \& Orskov H. The effect of oral glucose on serum free insulin-like growth factor-I and -II in health adults. J Clin Endocrinol Metab 199782 3124-3127.

14. Nakagawa $E$, Nagaya $N$, Okumura $H$, Enomoto $M$, Oya $H$, Ono $F$, Hosoda $H$, Kojima $M$ \& Kangawa $K$. Hyperglycaemia suppresses the secretion of ghrelin, a novel growth-hormone-releasing peptide: responses to the intravenous and oral administration of glucose. Clin Sci (Lond) 2002103 325-328.

15. Pallotta JA \& Kennedy PJ. Response of plasma insulin and growth hormone to carbohydrate and protein feeding. Metabolism 196817 901-908.

16. Rabinowitz D, Merimee TJ, Maffezzoli R \& Burgess JA. Patterns of hormonal release after glucose, protein, and glucose plus protein. Lancet 19662 454-456.

17. van Loon L, Kruijshoop M, Menheere PP, Wagenmakers AJ, Saris WH \& Keizer HA. Amino acid ingestion strongly enhances insulin secretion in patients with long-term type 2 diabetes. Diabetes Care 200326 625-630.

18. Baker HW, Best JB, Burger HG \& Cameron DP. Plasma human growth hormone levels in response to meals: a reappraisal. Aust J Exp Biol Med Sci 197250 715-724.

19. Quabbe HJ, Bratzke HJ, Siegers U \& Elban K. Studies on the relationship between plasma free fatty acids and growth hormone secretion in man. J Clin Invest 197251 2388-2398.

20. Quabbe HJ, Ramek W \& Luyckx AS. Growth hormone, glucagon, and insulin response to depression of plasma free fatty acids and the effect of glucose infusion. J Clin Endocrinol Metab 197744 383-391.

21. Blackard WG, Hull EW \& Lopez A. Effect of lipids on growth hormone secretion in humans. J Clin Invest 197150 1439-1443.

22. Merimee TJ, Pulkkinen AJ \& Burton CE. Diet-induced alterations of hGH secretion in man. J Clin Endocrinol Metab 197642 931-937.

23. Fineberg SE, Horland AA \& Merimee TJ. Free fatty acid concentrations and growth hormone secretion in man. Metabolism 197221 491-498. 


\section{CHAPTER 5}

24. Cappon JP, Ipp E, Brasel JA \& Cooper DM. Acute effects of high fat and high glucose meals on the growth hormone response to exercise. J Clin Endocrinol Metab 199376 1418-1422.

25. Merimee TJ, Rabinowtitz D \& Fineberg SE. Arginine-initiated release of human growth hormone. Factors modifying the response in normal man. N Engl J Med 1969280 1434-1438.

26. Sartorio A, Agosti F, Marazzi N, Trecate L, Silvestri G, Lafortuna C, Cappa M, De Palo E, Faglia G, Corradini C, Cella S, Rigamonti A \& Muller EE. Gender-, age-, body composition- and training workload-dependent differences of $\mathrm{GH}$ response to a discipline-specific training session in elite athletes: a study on the field. J Endocrinol Invest 200427 121-129.

27. Abumrad NN, Rabin D, Diamond MP \& Lacy WW. Use of a heated superficial hand vein as an alternative site for the measurement of amino acid concentrations and for the study of glucose and alanine kinetics in man. Metabolism 198130 936-940.

28. Ensinck JW, Vogel RE, Laschansky EC \& Francis BH. Effect of ingested carbohydrate, fat, and protein on the release of somatostatin-28 in humans. Gastroenterology 1990 98 633-638.

29. Lloyd KC, Maxwell V, Ohning G \& Walsh JH. Intestinal fat does not inhibit gastric function through a hormonal somatostatin mechanism in dogs. Gastroenterology 1992103 1221-1228.

30. Welbourne TC. Increased plasma bicarbonate and growth hormone after an oral glutamine load. Am J Clin Nutr 199561 1058-1061. 


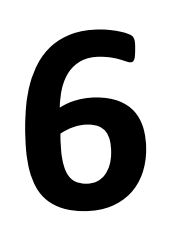

\section{Association between intake of dietary protein and 3y-change in body growth among normal and overweight $6 y$ old boys and girls (CosCIS)}

ANNEKE J.A.H. VAN VUGHT, BERIT L. HEITMANN, ARIE G. NIEUWENHUIZEN, MARGRIET A.B. VELDHORST, LARS BO ANDERSEN, HENRIETTE HASSELSTROM, ROBERTJAN M. BRUMMER, MARGRIET S. WESTERTERP-PLANTENGA

PUBLIC HEALTH AND NUTRITION, 2009 IN PRESS 


\section{ABSTRACT}

Background: Growth-hormone (GH) affects linear growth and body composition, by increasing the secretion of insulin-growth-factor-1 (IGF-1), muscle protein synthesis and lipolysis. The intake of protein (PROT) as well as the specific amino-acids arginine (ARG) and lysine (LYS) stimulates GH/IGF-1 secretion.

Objective: To investigate associations between PROT intake as well as intake of the specific amino acids ARG and LYS, and subsequent $3 y$-change linear growth and body-composition among 6y-old children.

Methods: Data of 223 children were collected from Copenhagen (Denmark), during 2001-2 and again 3 y later. Boys and girls were separated into normal weight and overweight, based on body mass index (BMI) quintiles. Fat free mass index (FFMI) and fat mass index (FMI) were calculated. Associations between change $(\Delta)$ in height, FMI, FFMI respectively and habitual PROT-intake as well as ARG and LYS were analysed by multiple-linear-regressions, adjusted for baseline height, FMI or FFMI and energy intake, age, physical activity and socio economic status.

Results: High ARG-intake was associated with linear growth $(\beta=1.09 \pm 0.54 p=0.05)$ among girls. Furthermore in girls, $\triangle \mathrm{FMI}$ was stronger inversely associated with high ARG-intake, if it was combined with high LYS-intake, instead of low LYS-intake $(p=0.03)$. No associations were found in boys.

Conclusion: In prepubertal girls linear growth may be influenced by habitual arginine-intake and body fat gain may be relatively prevented over time by the intake of the amino acids arginine and lysine. 


\section{INTRODUCTION}

Protein intake (PROT) is associated with greater velocity of linear growth in childhood ${ }^{1}$ as well as with a more beneficial body composition ${ }^{2-4}$. Some studies suggest that the amount of protein intake, but also the protein source have a regulatory effect on body growth, for instance milk protein is stronger associated with growth in height if compared with meat or vegetable protein ${ }^{5}$. Growth hormone (GH) and Insulin-like growth factor 1 (IGF-1) play a central role in the regulation of growth in height and width ${ }^{5,6}$. Besides the important role of GH/IGF-1 in regulating growth in height, it also regulates fat distribution and reduces fat mass ${ }^{7}$. Studies show an increased lipolysis and decreased fat mass after $\mathrm{GH}$ administration ${ }^{8-11}$. Dietary protein may be involved in secretion of GH and IGF-1, because protein restriction results in low IGF-1 concentrations in healthy children, which returned to normal after refeeding with proteins ${ }^{12}$. This finding is confirmed by a study showing that milk-protein, but not meat or vegetable protein, increases IGF-1 concentrations and growth in height ${ }^{5}$.

The effects of dietary protein on IGF-1 concentrations and growth ${ }^{1,11,13,14}$ may be mediated by a direct $\mathrm{GH}$-releasing effect of specific amino acids ${ }^{15-21}$, in particular arginine (ARG) and lysine (LYS) ${ }^{17,19,21}$. Previous studies suggest that the amino acid composition is crucial in understanding the mechanism through which protein may influence GH and IGF-1 production in relation to growth and body composition, since specific proteins, as gelatin protein (which is high in ARG), stimulate the $\mathrm{GH}$ release more potently than other protein-sources ${ }^{22}$. However no previous studies have been performed investigating the relationship between the intake of specific amino acids and the development of fat mass and fat free mass in pre-pubertal children.

In this study we investigated associations between the intakes of protein and more specific the amino acids ARG and LYS in the habitual diet and subsequent changes in linear growth, body fat and fat free mass, among normal weight and overweight 6-year old boys and girls. High intakes of PROT, and more specifically a high intake of ARG, especially in combination with a high intake of LYS, was expected to increase linear growth and the fat free mass index and decrease fat mass index.

\section{MATERIALS AND METHODS}

\section{Subjects}

The data were derived from a four-year prospective intervention study of physical activity and health, the Copenhagen School Child Intervention Study (CoSCIS). Children from 46 preschool classes (6-7 years of age) in 18 schools in two suburban 
communities in the Copenhagen area were invited to participate in the CoSCIS. In 2000 the community of Ballerup (10 schools, 27 classes) increased the number of physical exercise lessons from two to four a week for the first three years of school. The community of Taarnby ( 8 schools, 19 classes) was chosen as a control as it resembles Ballerup regarding the sociodemographic characteristics. The reported data in the present study are from the controls of this study (only community of Taarnby) ${ }^{23,24}$. A total of 706 children (69\% of those eligible) volunteered in the study, and written informed consent was obtained from the parents/guardians. Of these 706 children, 415 from Ballerup and 291 from Taarnby participated at baseline, 614 children were followed-up at $3^{\text {rd }}$ grade. The ethics committee of Copenhagen County approved the study. The measurements were performed from December 2001 until June 2002 preschool, at the 18 different schools and in the follow up from September 2004 until May 2005 at $3^{\text {rd }}$ grade. All control children with complete information about food intake, physical activity, socio economic status, height, weight and skin fold-thickness at baseline as well as height, weight and skin fold-thickness at follow up were included. According to these inclusion criteria 94 boys and 109 girls respectively were included.

\section{Measurements}

\section{Dietary intake}

Parents recorded the dietary intake of their child for seven consecutive days in supplied booklets with pre-coded fixed answer possibilities supplemented with a possibility for open answers. Food portions sizes were estimated from household measures and a series of photographs. This booklet for dietary record has been developed and used in nationwide dietary surveys since $1995^{25}$. The pre-printed diet records were delivered by the teachers in the schools in closed envelopes addressed to each child, who brought them home. The same logistic was used for return of the completedrecords.

Intakes of nutrients and foods were calculated using the General Intake Estimation System (DanishInstitute for Food and Veterinary Research 2005) based on the Danish food database ${ }^{26}$. The researchers computed the dietary information in a database, by which it was possible to calculate nutrient information (i.e. energy content, protein content, AA content) on the individual food items or whole meals and diets. Corrections for losses in cooking were made when calculating nutrient contents.

Reporting of dietary intake of energy was evaluated by comparing reported energy intake with estimations of energy expenditure (based on basal metaolic rate (Harris \& Benedict) and physical activity level (PAL). The PAL in children varies between 1.3 
and $1.9^{27}$. Children who reported an energy intake below BMR*1.3 or above $\mathrm{BMR}^{*} 2.0$ were excluded.

\section{Anthropometry \& other measurements}

All measurements were carried out using standardised methods, which have been described in detail elsewhere ${ }^{23,24}$.

Height was measured by a Harpenden stadiometer to the nearest $1 \mathrm{~mm}$. Body weight was measured to the nearest $0.1 \mathrm{~kg}$ using a SECA electronic scale. Both measurements were performed during school-time by experienced scientists. Bicipital, tricipital, subscapular, and suprailiac skinfolds were measured with a Harpenden skin fold calliper to the nearest $1 \mathrm{~mm}$. The dominant side of the body was determined by asking the child to take a pen and write his/her name. The data shown in this study represent the mean of three measurements taken on the nondominant side of the body. The sum of four skin folds (SFS) was used to calculate body fat percentage. Children were divided into quintiles according to their BMI, adjusted for sex and age ${ }^{28}$. Analyses were first performed in the whole group of girls and boys and later the groups were divided in BMI quintile 1-4 and BMI quintile 5 .

Habitual physical activity (PA) was measured by the MTI 7164 activity monitor (Manufactory Technology Inc, Fort Walton Beach, Florida, USA). This monitor has been validated in several studies and has shown both high mechanical reproducibility and good validity with respect to free living conditions in children ${ }^{24}$. To allow familiarisation, the children had to wear the MTI monitor one day before recording. It was secured directly to the skin at the lower back using an elastic belt. The children were instructed to wear the monitor continuously except during water based activities or when sleeping. A mean count was calculated for each child ${ }^{24}$. The classification of socio-economic status (SES) was based on information regarding the education of the mother in the household at the first measurement point, since recent studies suggests that the risk factors considered in this study are stronger associated with the SES of the mother rather than that of the father ${ }^{29-31}$. The education level of the mother was divided in 7 categories; $(1)<7$ yrs education, (2) 7-8 yrs education, (3) 9-10 yrs completed. elementary school, (4) 12 yrs. high school, (5) short non-university programmes under $3 \mathrm{y}$, (6) college $3-4 y$; (7) university degree over $4 y$.

\section{Calculation of FFM and FM}

The body fat percentage was estimated from the skin fold thickness using the equations from Weststrate ${ }^{32}$; 
(i) girls aged $2-10$ years: Fat\% $=((562-1.1($ age-2) $) / D)-(525-1.4($ age- 2$))$ and

(ii) girls aged $11-18$ years: Fat\% $=((533-7.3($ age-10) $) / D)-(514-8.0($ age-10 $))$ and

(iii) boys aged $2-18$ years: Fat\% $=((562-4.2($ age- 2$)) / D)-(525-4.7($ age-2) $)$

$\mathrm{D}=$ Total body density estimated from following equations: (i) girls aged 2-10 y: $\mathrm{D}=(1.1315+$ $0.0004 *($ age-2) $)-((0.0719-0.0003 *($ age-2) $) * \log 4$ skin) and (ii) girls aged $11-18 \mathrm{y}: \mathrm{D}=(1.1350+$ $0.0031 *($ age-10) $)-((0.0719-0.0003 *($ age-2) $) * \log 4$ skin) and (iii) boys aged 2-18 y: D $=(1.1315+$ $0.0018 *($ age-2) $)-\left((0.0719-0.0006 *(\text { age-2 }))^{*} \log 4\right.$ skin $)$ where Log4skin $=\log ($ mean of the four skinfold thickness).

The fat mass (FM) and the fat free mass (FFM) were calculated from the body weight and the estimated body fat (\%). FM and FFM were divided by squared height, to calculate fat-free mass index (FFMI) and fat mass index (FMI) respectively ${ }^{33}$. These indices have been proposed as indicator of nutritional status, and because $\mathrm{FMI}+\mathrm{FFMI}=\mathrm{BMI}$, their use allows to asses the contribution of fat mass and fat-free mass to $\mathrm{BMI}^{33}$.

Table 1: Characteristics of boys and girls aged 6 years and 9 years according to BMI quintiles.

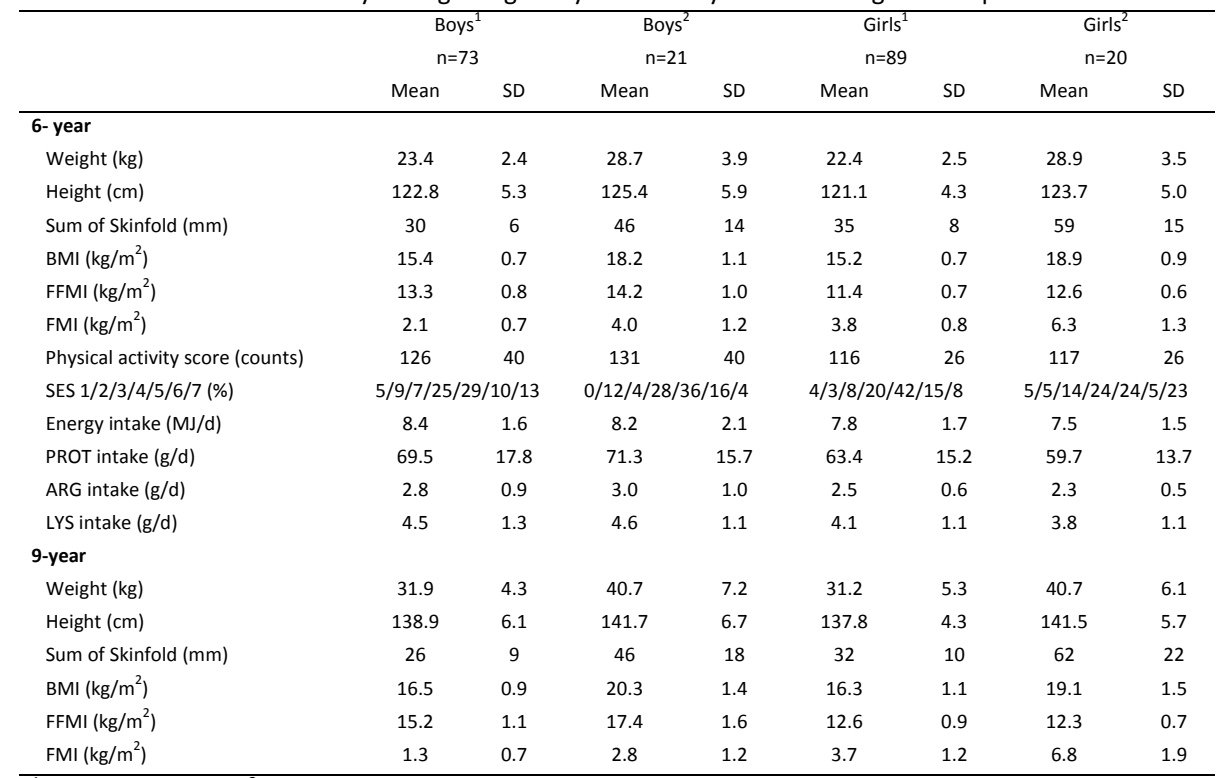

${ }^{1} \mathrm{BMI}$-quintiles 1-4, ${ }^{2} \mathrm{BMI}$-quintile 5, PROT= Total protein, ARG = Arginine, LYS = Lysine, BMI = Body Mass Index, FFMI= Fat Free Mass Index, FMI= Fat Mass Index, SES = Socio Economic Status

\section{Statistical analysis}

Each dietary and anthropometric variable was treated as a continuous variable. The relationship between $\Delta$ height, $\triangle \mathrm{FMI}$, or $\triangle \mathrm{FFMI}$ and intake of PROT as well as the intake of ARG or LYS at age 6y was assessed by a multiple regression model includ- 
ing the covariates; baseline height, FMI or FFMI, age, energy intake (EI), PA and SES. The interaction of ARG with LYS was estimated in a model with the same covariates as the model described above. This model was converted to the final regression model, by dividing LYS into low and high LYS intake. Low LYS-intake was defined as LYS intake below median and high LYS-intake as LYS intakes above median. Since there was an interaction between the independent variables PROT, ARG, LYS and gender, data of boys and girls were analysed separately. After analysing data of boys and girls separately, they were divided in either the $1-4^{\text {th }}$ quintile of $\mathrm{BMI}$ (leaner children) or in the $5^{\text {th }}$ quintile of BMI (heavier children) to investigate if there is a difference in growth influenced by protein intake between the leaner children and the heavier children. To test the significance of the contribution of the variables, an F-test was used. The characteristics are expressed as mean \pm SD. All other values are expressed as mean \pm SE. A p-value $<0.05$ was considered as indicating statistical significance. All statistical analyses were performed using SPSS for WINDOWS, version 14.0; SPSS, Chicago, IL.

\section{RESULTS}

The characteristics of the children, grouped by study year, gender and quintile of BMI are shown in Table 1.

The results are summarized in Table 2 and 3 , with $\Delta$ height, $\Delta \mathrm{FMI}$ and $\Delta \mathrm{FFMI}$ as dependent variables and habitual intake of PROT as well as the specific amino acids ARG, LYS and the interaction between ARG and LYS as independent variables. Adjustments were made for the covariates; baseline height, FMI or FFMI, age, El, PA, SES .

\section{Association between change in height and habitual intake of PROT, and specifi- cally ARG and LYS intake}

Among girls, growth in height was associated with a high intake of ARG $(\beta=1.09 \pm 0.54 p<0.05)$, but intake of PROT or LYS was not associated with changes in linear growth (Table 2). Among boys this association did not reach significance. 


\section{CHAPTER 6}

Table 2: Adjusted models showing the associations between both ARG and LYS ( $\mathrm{g} /$ day) intakes and changes in height $(\mathrm{m}) \mathrm{FMI}$ and FFMI $\left(\mathrm{kg} / \mathrm{m}^{2}\right)$

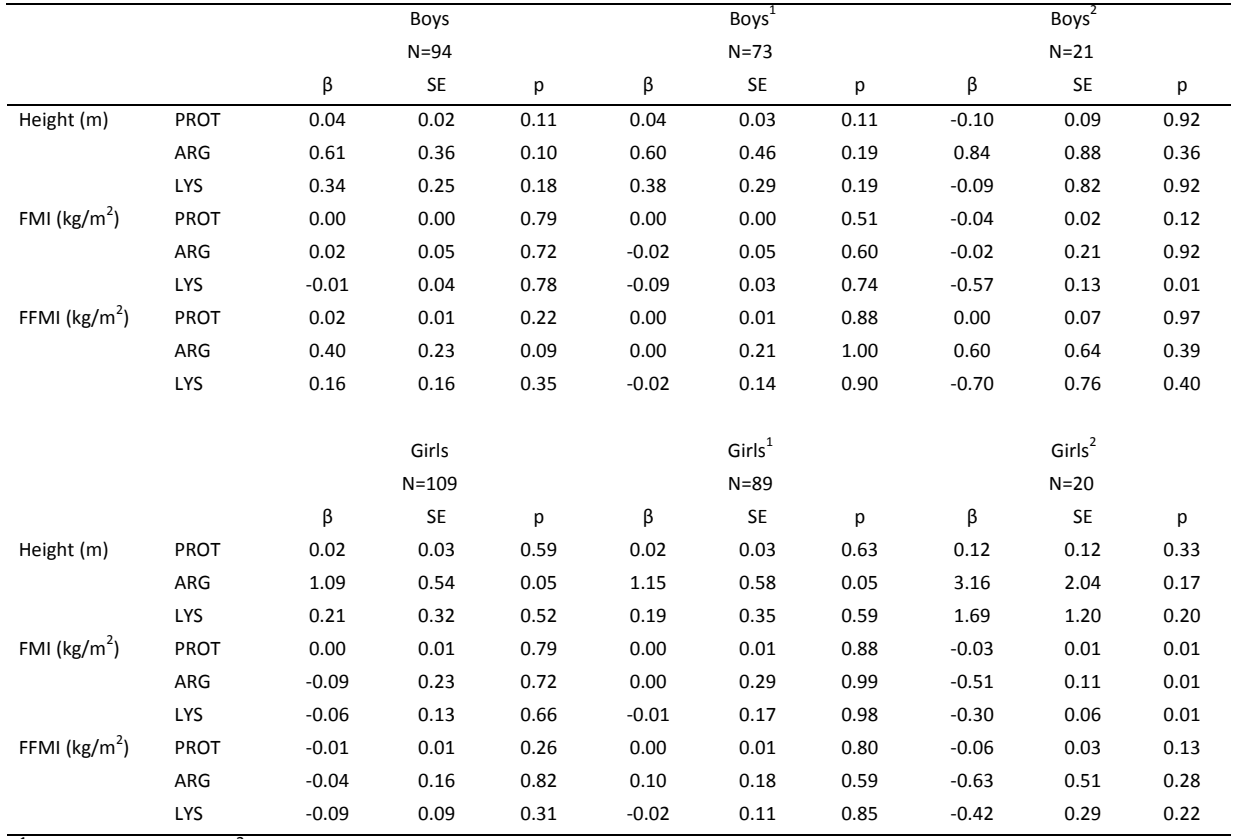

${ }^{1} \mathrm{BMI}$-quintiles 1-4, ${ }^{2} \mathrm{BMI}$-quintile 5, PROT= total protein, ARG = arginine, LYS = lysine, FFMI= Fat Free Mass Index $\left(\mathrm{kg} / \mathrm{m}^{2}\right), \mathrm{FMI}=$ Fat Mass Index $\left(\mathrm{kg} / \mathrm{m}^{2}\right)$

Table 3: Final models between the interaction of ARG and LYS (g/day) and height $(\mathrm{m})$, FMI and FFMI $\left(\mathrm{kg} / \mathrm{m}^{2}\right)$

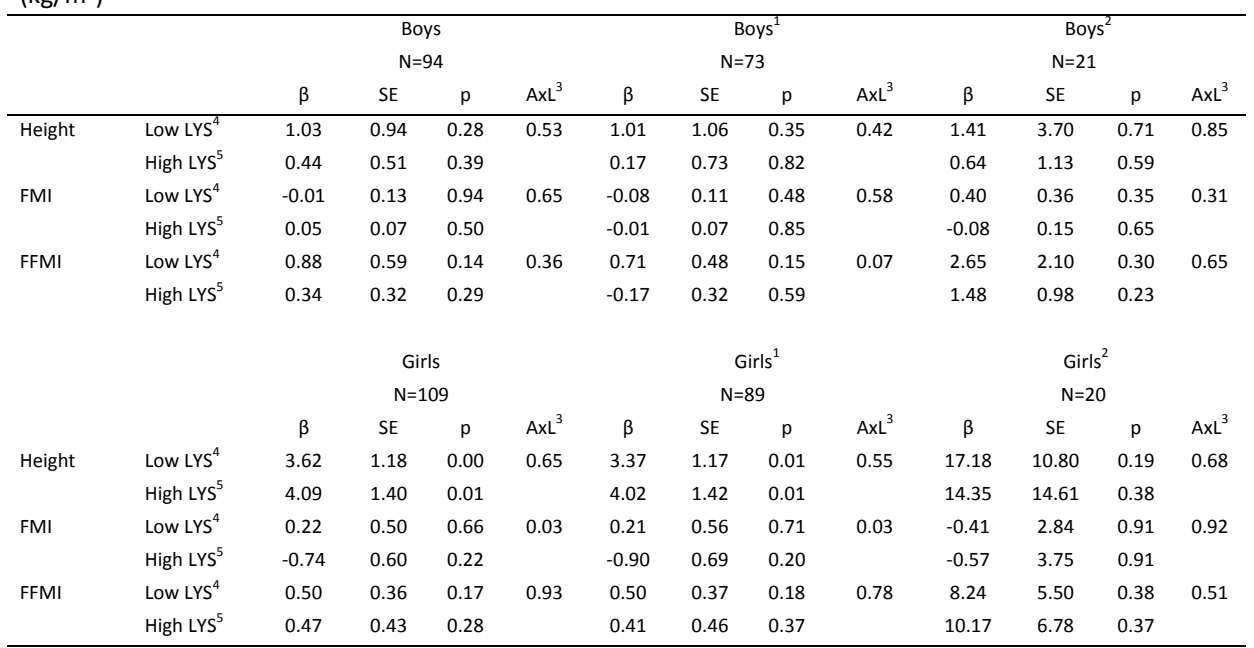

${ }^{1} \mathrm{BMI}$-quintiles 1-4, ${ }^{2} \mathrm{BMI}$-quintile $5,{ }^{3}$ Arginine X Lysine interactions, ${ }^{4} \mathrm{LYS}<4.25 \mathrm{~g} /$ day, ${ }^{5} \mathrm{LYS}>4.25 \mathrm{~g} /$ day, ARG $=$ Arginine, LYS $=$ Lysine, FFMI = Fat Free Mass Index $\left(\mathrm{kg} / \mathrm{m}^{2}\right)$, FMI= Fat Mass Index $\left(\mathrm{kg} / \mathrm{m}^{2}\right)$ 


\section{Association between change in FMI and habitual intake of PROT, and specifically ARG and LYS intake}

Significant associations were found between changes in FMI and habitual intakes of PROT as well as for the specific amino acids ARG or LYS separately or combined ( $\beta=-$ $0.03 \pm 0.01 p=0.01, \beta=-0.51 \pm 0.11 p=0.01, \beta=-0.30 \pm 0.06 p=0.01$ respectively) among girls with a BMI in the $5^{\text {th }}$ percentile, but not among the girls with a BMI in the $1-4^{\text {th }}$ quintile (Table 2 and 3). Among boys, no associations were found between $\Delta \mathrm{FMI}$ and the intake of PROT, significant associations however were found between $\Delta F M I$ and the intake of the specific amino acid LYS, among boys with a BMI in the $5^{\text {th }}$ quintile $(\beta=-0.57 \pm 0.13 p=0.01$ ) (Table 2 ).

Further analyses showed that ARG and LYS were not independently related to changes in $\triangle F M I(p=0.03)$ (Table 3$)$. The interaction analysis showed that among girls with a $\mathrm{BMI}$ in the $1-4^{\text {th }}$ quintile, a stronger inverse correlation was found between $\triangle \mathrm{FMI}$ and ARG intake if LYS intake was high, than if LYS intake was low $(p=0.03)$ (Fig 1).

\section{Association between change in FFMI and habitual intake of PROT, and specifically ARG and LYS intake}

No associations were found between change in FFMI and habitual intake of PROT, ARG or LYS (Table 2).

Figure 1: Interaction of ARG and LYS (g/day) and FMI $\left(\mathrm{kg} / \mathrm{m}^{2}\right)$ among girls. - - -. high LYS (> 4.25g/day) ARG = Arginine, LYS = Lysine, FMI= Fat Mass Index

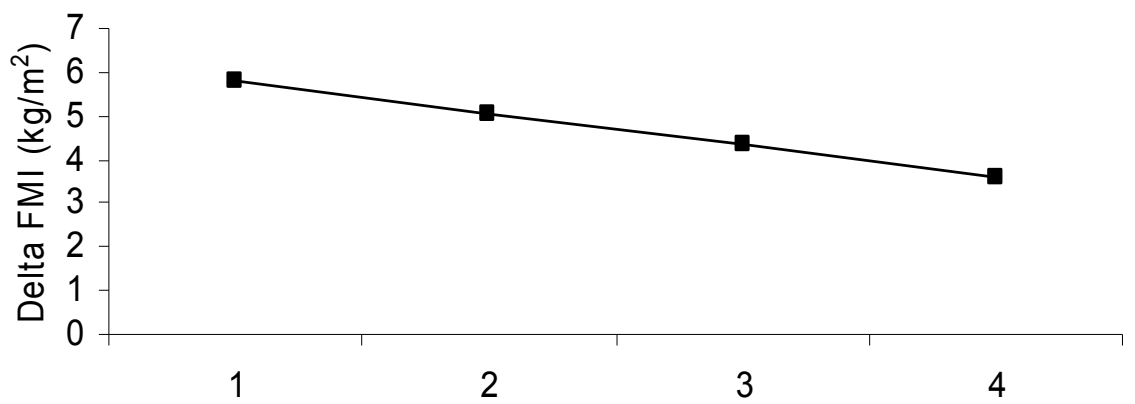

Arginine (g/day) 


\section{DISCUSSION}

The present study shows that linear growth as well as the development of body composition may be influenced by habitual dietary intake of the amino acids ARG and LYS, among pre-pubertal girls.

The association between linear growth and the intake of ARG, may be explained by the stimulation of the somatotropic axis by ARG, since ARG is a potent stimulator of GH secretion ${ }^{16}$ and GH plays an important role in linear growth ${ }^{5,34}$. This association only reached significance in girls $(p<0.05)$, but also in boys the association had the same direction and magnitude $(p=0.10)$. For the intake of PROT in general or LYS the association with linear growth was weaker, indicating that in particular ARG is an important dietary determinant of linear growth. We could, however, not confirm the involvement of the somatotropic axis within this study as plasma IGF-1 concentrations were not available in this cohort. Previous studies, investigating the effects of dietary protein source on growth in height showed increased IGF-1 concentrations as well as growth in height after intake of milk protein, but not after intake of animal or vegetable protein, which suggests an influence of specific amino acid concentrations or combinations influencing IGF-1 concentrations and growth in height ${ }^{5,13}$.

Besides the association between ARG and linear growth, high intakes of ARG, combined with high intakes of LYS, is associated with a relative decrease in FMI. This may also be explained by stimulating effects of these amino acids on $\mathrm{GH}$ secretion ${ }^{16,17}$, since $\mathrm{GH}$ is known to decrease body fat mass index ${ }^{35}$. The sub-group analyses were based on small numbers which may have prevented the finding of significant associations between protein intake and FMI for the boys. All associations however were in the same direction for boys and girls, which suggest that protein was of importance for growth.

The interactions between the amino acids suggest that the effect of proteins is depending on the available amount and combination of specific amino acids, such as ARG and LYS as demonstrated in the present study. The somatotropic regulation of growth and body composition could thus be modulated by privileged amino acids and proteins ${ }^{1}$. In a recent study, we found remarkable differences in the potency of various dietary proteins to stimulate the somatotropic activity, with gelatin (high in ARG) showing the largest increase on $\mathrm{GH}$ secretion among other proteins $^{22}$.

In the present study, the mean intake per day of PROT was $66 \pm 16$ gram/day (2.6 gram $/ \mathrm{kg} /$ day), which is considerably above the requirement of $0.95 \mathrm{~g} / \mathrm{kg} / \mathrm{day}$ [NHANES III]. However, the same protein intake was also seen in other studies among Danish children ${ }^{1,21}$. The mean intake per day of ARG was $2.6 \pm 0.8 \mathrm{gram} /$ day and for LYS $4.3 \pm 1.2$ gram/day, which is in accordance with the requirements for adults [NHANES III]. For children no accepted requirement values are published 
[WHO report 2007]. ARG is present in large amounts in products like nuts, seeds, fish and meat, and particularly high concentrations are present in walnuts, sesamseeds and shell-fish. LYS is present in meat and milk-products and is found in particularly high amounts in beef and cheese.

It should be noted that information on dietary intakes was obtained using a 7-days food record, and that measurement error may have occurred, as also indicated by the lower total energy intake among the children in the $5^{\text {th }} \mathrm{BMI}$ quintile compared with the lean children. However, all dietary instruments used to assess habitual diet intake have random as well as specific errors ${ }^{36}$. On the other hand studies have shown that although energy intake is frequently underreported, protein reporting is more accurate ${ }^{37}$. Therefore, we believe that the present data, especially with respect to protein intake, indeed largely reflect true intake levels. Moreover, in order to be able to take energy intake into account as covariate, we excluded clear under reporters and over reporters. Misreporters consisted of a few under reporters, they were clearly inaccurate reporters. Over reporting occurred more often, since parents/ caretakers report on children ${ }^{38,39}$. The ability of the parents to quantify portion sizes causes errors in quantification, for instance, parents report what they believe their child should eat, rather than what they actually do eat ${ }^{38}$.

The results of the present study suggest that a physiological role of habitual PROT intake may depend on the amount and the combination of specific amino acids that may add to our understanding of how to perform future dietary intervention among pre-pubertal children, on growth in height and the regulation of body composition in later life. This has to be further investigated by experimental designs.

In conclusion, in prepubertal girls linear growth may be influenced by habitual ARG intake and body fat gain may be relatively prevented over time by a high intake of the combination of the amino acids ARG and LYS.

\section{ACKNOWLEDGEMENTS}

We would like to acknowledge the members of the Copenhagen School Children Intervention Study for making their data available. The authors wish to acknowledge the helpful assistance from statistician Michael Gamborg in analysing data. 


\section{REFERENCES}

1. Hoppe C, Molgaard C, Thomsen BL, Juul A \& Michaelsen KF. Protein intake at 9 mo of age is associated with body size but not with body fat in 10-y-old Danish children. Am J Clin Nutr 200479 494-501.

2. van Vught J, Heitmann B, Nieuwenhuizen A, Veldhorst $M$, Brummer $R$ \& Westerterp-Plantenga $M$. Association between dietary protein and 6y-change in body composition among normal and overweight 9y old boys and girls (EYHS) (submitted). 2008.

3. Weigle DS, Breen PA, Matthys CC, Callahan HS, Meeuws KE, Burden VR \& Purnell JQ. A high-protein diet induces sustained reductions in appetite, ad libitum caloric intake, and body weight despite compensatory changes in diurnal plasma leptin and ghrelin concentrations. Am J Clin Nutr 2005 82 41-48.

4. Westerterp-Plantenga MS, Lejeune MP, Nijs I, van Ooijen M \& Kovacs EM. High protein intake sustains weight maintenance after body weight loss in humans. Int J Obes Relat Metab Disord 200428 57-64.

5. Hoppe C, Udam TR, Lauritzen L, Molgaard C, Juul A \& Michaelsen KF. Animal protein intake, serum insulin-like growth factor I, and growth in healthy 2.5-y-old Danish children. Am J Clin Nutr 200480447 452.

6. Rolland-Cachera M. Prediction of adult body composition from infant and child measurements. In Body composition techniques in health and disease, pp 100-145. Ed CT Davies PSW, eds. Cambridge, United Kingdom: Cambridge University Press, 1995.

7. Bengtsson BA, Brummer RJ, Eden S, Rosen T \& Sjostrom L. Effects of growth hormone on fat mass and fat distribution. Acta Paediatr Suppl 1992383 62-65; discussion 66.

8. Attallah $H$, Friedlander AL \& Hoffman AR. Visceral obesity, impaired glucose tolerance, metabolic syndrome, and growth hormone therapy. Growth Horm IGF Res 200616 Suppl A S62-67.

9. Buijs MM, Burggraaf J, Langendonk JG, Schoemaker RC, Frolich M, Arndt JW, Cohen AF, Romijn JA, Ackermans MT, Sauerwein HP, Meinders AE \& Pijl H. Hyposomatotropism blunts lipolysis in abdominally obese women. J Clin Endocrinol Metab 200287 3851-3858.

10. Pasarica M, Zachwieja JJ, Dejonge L, Redman S \& Smith SR. Effect of Growth Hormone on Body Composition and Visceral Adiposity in Middle Aged Men with Visceral Obesity. J Clin Endocrinol Metab 2007.

11. Snel YE, Brummer RJ, Doerga ME, Zelissen PM, Bakker CJ, Hendriks MJ \& Koppeschaar HP. Adipose tissue assessed by magnetic resonance imaging in growth hormone-deficient adults: the effect of growth hormone replacement and a comparison with control subjects. Am J Clin Nutr 199561 1290-1294.

12. Smith WJ, Underwood LE \& Clemmons DR. Effects of caloric or protein restriction on insulin-like growth factor-I (IGF-I) and IGF-binding proteins in children and adults. J Clin Endocrinol Metab 1995 80 443-449.

13. Hoppe C, Molgaard C, Juul A \& Michaelsen KF. High intakes of skimmed milk, but not meat, increase serum IGF-I and IGFBP-3 in eight-year-old boys. Eur J Clin Nutr 200458 1211-1216.

14. Rabinowitz D, Merimee TJ, Maffezzoli R \& Burgess JA. Patterns of hormonal release after glucose, protein, and glucose plus protein. Lancet 19662 454-456.

15. Chromiak JA \& Antonio J. Use of amino acids as growth hormone-releasing agents by athletes. Nutrition 200218 657-661.

16. Collier SR, Casey DP \& Kanaley JA. Growth hormone responses to varying doses of oral arginine. Growth Horm IGF Res 200515 136-139.

17. Isidori A, Lo Monaco A \& Cappa M. A study of growth hormone release in man after oral administration of amino acids. Curr Med Res Opin 19817 475-481.

18. Knopf RF, Conn JW, Fajans SS, Floyd JC, Guntsche EM \& Rull JA. Plasma Growth Hormone Response to Intravenous Administration of Amino Acids. J Clin Endocrinol Metab 196525 1140-1144.

19. Suminski RR, Robertson RJ, Goss FL, Arslanian S, Kang J, DaSilva S, Utter AC \& Metz KF. Acute effect of amino acid ingestion and resistance exercise on plasma growth hormone concentration in young men. Int J Sport Nutr 19977 48-60.

20. Welbourne TC. Increased plasma bicarbonate and growth hormone after an oral glutamine load. Am J Clin Nutr 199561 1058-1061.

21. van Vught JAH, Heitmann BL, Nieuwenhuizen AG, Veldhorst MAM, Brummer RJM \& WesterterpPlantenga MS. Association between dietary protein and 6y-change in body composition among normal and overweight 9y old boys and girls (EYHS) (in press). Clinical Nutrition 2008.

22. van Vught AJ, Nieuwenhuizen AG, Veldhorst MAB, Brummer RJ \& Westerterp-Plantenga MS. Somatotropic effects of the protein; soy, gelatin, alpha-lactalbumin and milk. (Submitted) 2008. 
23. Hasselstrom H, Karlsson KM, Hansen SE, Gronfeldt V, Froberg K \& Andersen LB. Sex differences in bone size and bone mineral density exist before puberty. The Copenhagen School Child Intervention Study (CoSCIS). Calcif Tissue Int 2006 79 7-14.

24. Hasselstrom H, Karlsson KM, Hansen SE, Gronfeldt V, Froberg K \& Andersen LB. Peripheral bone mineral density and different intensities of physical activity in children 6-8 years old: the Copenhagen School Child Intervention study. Calcif Tissue Int 200780 31-38.

25. Lyhne N, Christensen, T, Groth, MV, Fagt, S, Ed. Danskernes kostvaner 2000-2002. Soborg, Denmark, 2005.

26. Moller A, Saxholt E, Christensen T \& Hartkopp H. Fødevaredatabanken, version 6.0. Søborg: Danmarks Fødevareforskning, www.foodcomp.dk 2005.

27. Hoos MB, Kuipers H, Gerver WJ \& Westerterp KR. Physical activity pattern of children assessed by triaxial accelerometry. Eur J Clin Nutr 200458 1425-1428.

28. Cole TJ, Bellizzi MC, Flegal KM \& Dietz WH. Establishing a standard definition for child overweight and obesity worldwide: international survey. Bmj $20003201240-1243$.

29. Gnavi R, Spagnoli TD, Galotto C, Pugliese E, Carta A \& Cesari L. Socioeconomic status, overweight and obesity in prepuberal children: a study in an area of Northern Italy. Eur J Epidemiol 200016 797-803.

30. Klein-Platat C, Wagner A, Haan MC, Arveiler D, Schlienger JL \& Simon C. Prevalence and sociodemographic determinants of overweight in young French adolescents. Diabetes Metab Res Rev 200319153 158.

31. Kristensen PL, Wedderkopp N, Moller NC, Andersen LB, Bai CN \& Froberg K. Tracking and prevalence of cardiovascular disease risk factors across socio-economic classes: a longitudinal substudy of the European Youth Heart Study. BMC Public Health 2006620.

32. Weststrate JA \& Deurenberg P. Body composition in children: proposal for a method for calculating body fat percentage from total body density or skinfold-thickness measurements. Am J Clin Nutr 198950 1104-1115.

33. Wells JC \& Cole TJ. Adjustment of fat-free mass and fat mass for height in children aged $8 \mathrm{y}$. Int $\mathrm{J}$ Obes Relat Metab Disord 200226 947-952.

34. Veldhuis JD, Roemmich JN, Richmond EJ, Rogol AD, Lovejoy JC, Sheffield-Moore M, Mauras N \& Bowers CY. Endocrine control of body composition in infancy, childhood, and puberty. Endocr Rev $200526114-$ 146.

35. Fu WJ, Haynes TE, Kohli R, Hu J, Shi W, Spencer TE, Carroll RJ, Meininger CJ \& Wu G. Dietary L-arginine supplementation reduces fat mass in Zucker diabetic fatty rats. J Nutr 2005 135 714-721.

36. Westerterp KR \& Goris AH. Validity of the assessment of dietary intake: problems of misreporting. Curr Opin Clin Nutr Metab Care 20025 489-493.

37. Heitmann BL \& Lissner L. Dietary underreporting by obese individuals--is it specific or non-specific? $B m j$ $1995311986-989$.

38. Livingstone MB \& Robson PJ. Measurement of dietary intake in children. Proc Nutr Soc 200059 279-293.

39. Warren JM, Henry CJ, Livingstone MB, Lightowler HJ, Bradshaw SM \& Perwaiz S. How well do children aged 5-7 years recall food eaten at school lunch? Public Health Nutr 20036 41-47. 



\section{Association between dietary protein and change in body composition among children \\ (EYHS)}

ANNEKE J.A.H. VAN VUGHT, BERIT L. HEITMANN, ARIE G. NIEUWENHUIZEN, MARGRIET A.B. VELDHORST, ROBERT-JAN M. BRUMMER, MARGRIET S. WESTERTERPPLANTENGA

CLINICAL NUTRITION, 2009 IN PRESS 


\section{ABSTRACT}

Background \& Aim: Growth hormone affects body composition by a relatively reduced fat-mass and increased fat-free-mass. The intake of protein as well as the specific amino-acids arginine and lysine potently stimulate GH secretion. This study investigated associations between intakes of protein, arginine, lysine and subsequent 6-year change in body-composition among 8-10-year old children.

Methods: Data of 364 children were collected from Odense, Denmark, during 19971998 and 6-year later as part of the European Youth Heart Study. Body Mass Index among children was subdivided by fat free mass index (FFMI) and fat mass index (FMI), based on skinfold-measurements. Dietary intake was estimated via 24hrecall. Associations between intakes of protein as well as arginine, lysine and change in FFMI and FMI were analysed by multiple linear regressions, adjusted for social economic status, puberty stage and physical-activity-level.

Results: Among lean girls inverse associations were found between protein as well as arginine and lysine intake and change in FMI $(\beta=-1.12 \pm 0.56, p=0.03, \beta=-$ $1.10 \pm 0.53, p=0.04, \beta=-1.13 \pm 0.51, p=0.03$ respectively). Furthermore among girls with a body mass index in the $5^{\text {th }}$ quintile, protein intake was associated with $\triangle F F M I(p=0.04)$, and more specific when LYS-intake was high, ARG-intake was associated with $\triangle F F M I(p=0.04)$.

Conclusion: Among girls high protein intakes may decrease body fat gain and increase fat free mass gain, depending on the available amounts and combinations of arginine and lysine. 


\section{INTRODUCTION}

The prevalence of obesity is rapidly increasing worldwide among adults, adolescents and children. Characteristics of overweight and obesity include higher percentages of body fat and lower concentrations of growth hormone $(\mathrm{GH})$ and Insulin like Growth Factor-1 (IGF-1) ${ }^{1}$. GH plays an important role in regulating fat distribution and reducing fat mass ${ }^{1}$ and studies show an increased lipolysis and decreased fat mass after $\mathrm{GH}$ administration ${ }^{1,2}$. Dietary proteins ${ }^{3,4}$, in particular gelatin [submitted data of our previous work], as well as specific amino acids (AAs) ${ }^{5,6}$, particularly arginine (ARG) alone or in combination with lysine (LYS) ${ }^{4,5}$, have been shown to stimulate the somatotropic axis. This protein induced somatotropic activity may influence the development of body composition and could be underlying in the finding that PE\% (protein intake as percentage from the energy intake) is negatively associated with ponderal index ${ }^{7}$.

This study aimed to investigate the relationship between the intake of proteins during the prepubertal phase on the development of fat-mass (FM) and fat-freemass (FFM) towards puberty. Since studies suggest that amino acid composition is crucial in understanding the mechanism through which protein may influence $\mathrm{GH}$ and IGF-1 production in relation to growth and body composition, we also investigated the role of specific amino acids, i.e., ARG and LYS, on the development of FM and FFM.

For this purpose, we studied the associations between the intakes of protein and more specifically the amino acids ARG and LYS in the diet and subsequent changes in FM and FFM, among 9 years old children.

\section{MATERIALS AND METHODS}

\section{Subjects}

The data were derived from the Danish part of the European Youth Heart Study (EYHS).The subjects all lived and attended school in the community of Odense in 1997-2003, and participated in both EYHS-I, as 8-10 year old third grade children, and in the follow-up study, EYHS-II, in 2003 as 14-16 year old ninth grade adolescents.

Altogether 711 8- 10 year old children, who attended schools in the county of Odense, Denmark, were invited to participate in the study, along with their parents. Sampling went as follows; Schools were stratified according to location (urban, suburban, rural) and socioeconomic profile of uptake area (high, middle, low). From each stratum, a proportional, two-stage cluster sample of children was selected. The primary units were the schools. The sampling frame for schools was a 
complete list of public schools in Odense, from which schools were sampled using probability proportional to school size. The secondary units were the children within the schools, and equal numbers of children were sampled from each school. The children were allocated code numbers and randomly selected using random number tables.

Twenty-eight out of 35 schools were asked to participate and 25 agreed. The only two urban low-income area schools in Odense were sampled, 20 out of 24 schools from middle-income areas, two out of four schools in high-income areas, and four out of five rural area schools were sampled. Of the three nonparticipating schools, one was rural, one was urban from middleclass area, and one was urban from a low-income area. All these three schools gave interference with the educational process as reason for not participating.

In total 771 third grade children participated in EYHS-I and 384 of these children (214 girls and 170 boys) were re-examined in EYHS-II as ninth grade students, corresponding to $49.8 \%$ of the original sample. One of the reasons for nonparticipation in the follow-up study was reluctance to travel to the city of Odense for the examinations by several of the participants in EYHS-I, who no longer lived in the community of Odense at the time EYHS-II was initiated. If the coefficient of participation is calculated only taking into account subjects who still attended school in the municipality of Odense in 2003, the coefficient rises from $49.8 \%$ to $57.0 \%$. In total 180 girls and148 boys with complete information on all variables were included in the present study.

\section{Measurements}

\section{Dietary intake}

Information on habitual dietary intake was obtained by a $24 \mathrm{~h}$ recall, supported by a qualitative food record at the first measurement point. The children completed a qualitative food record at home, followed the next day by a face to face interactive interview carried out by the same interviewer for all children. Interviews were carried out on school days, so dietary intake was not obtained for Fridays and Saturdays. The quantity of foods eaten and meals was estimated using common household measures and food pictures ${ }^{8,9}$. Afterwards, the interviewer computed the dietary information (i.e. energy content, protein content, AA content) in a database, by which it was possible to calculate nutrient information on the individual food items or whole meals and diets via the Danish national food composition tables ${ }^{10}$. 


\section{Calculation of FFM and FM}

Skinfold thickness (SFT) was measured at the first and second measurement point (age 8-10 year and 14-16 year respectively) with a Harpenden carlliper(John Bull; British Indicators Ltd, Birmingham, UK). SFT was obtained for each child twice on the left-hand side at four locations, the triceps brachii and biceps brachii muscles, subscapularly, and superior to the anterior superior iliac spine ${ }^{11,12}$, and were finally expressed as the sum of the four skinfold thicknesses in $\mathrm{mm}(\Sigma \mathrm{SF})$. The same male investigator made all the skinfold measurements on the boys, whereas two female investigators made all the measurements on the girls. The inter- and intra-test Pearson correlation coefficients were 0.988 and 0.998 between skinfold measurements.

The body fat percentage (fat\%) was estimated from the skinfold measurements using the equations given by Weststrate et al (in 1989).;

(i) girls aged $2-10$ years: Fat\%=((562-1.1(age-2))/D)-(525-1.4(age-2)) and

(ii) girls aged $11-18$ years: Fat\% $=((533-7.3($ age-10) $) / D)-(514-8.0($ age-10) $)$ and

(iii) boys aged $2-18$ years: Fat\% $=((562-4.2($ age- 2$)) / D)-(525-4.7($ age- 2$))$

$D=$ Total body density estimated from following equations: (i) girls aged 2-10y: $D=(1.1315+0.0004 *$ (age2))-((0.0719-0.0003*(age-2))*log4skin) and (ii) girls aged 11-18y: $D=(1.1350+0.0031 *$ (age10))-((0.0719-0.0003*(age-2))*log4skin) and (iii) boys aged $2-18 \mathrm{y}$ : $\mathrm{D}=\left(1.1315+0.0018^{*}\right.$ (age2)) $-((0.0719-0.0006 *$ (age-2) $) * \log 4$ skin $)$ where $\log 4$ skin $=\log ($ ( mean of the four skinfold thickness $)$ and age in years.

FM and FFM were estimated from the body weight and the estimated fat\%. Both FM and FFM were divided by height square $(\mathrm{HT})^{2}$, to calculate FFM index (FFMI) and FM index (FMI).

\section{Other measurements}

Physical activity was estimated with a questionnaire at the first measurement point. In this study, the question 'Exercise, which is most like you?' with possible answers; 'I don't exercise', 'I exercise sometimes but not regularly' and 'I exercise regularly' was used since this question was the most appropriate about the freeliving physical activity. Results after using CSA-accelerometer as covariate showed the same results as using the questionnaire as covariate for physical activity. However only in $60 \%$ of the total sample we had measurements of PA by CSA accelerometer, therefore we decided to use the questionnaire as covariate for physical activity in the analysis.

The classification of socio-economic status (SES) was based on information regarding the adult female in the household at the first measurement point, since recent evidence suggests that the risk factors considered in this study are stronger associated with the SES of the mother rather than that of the father. 
Assessment of puberty status was based on Tanner's pubic hair stages for boys and Tanner's breast development for girls.

Table 1: Characteristics of boys and girls aged 8-10 years and 14-16 years according to BMI quintiles

\begin{tabular}{|c|c|c|c|c|c|c|c|c|c|c|c|c|c|c|c|c|c|c|}
\hline & \multirow{2}{*}{\multicolumn{3}{|c|}{$\begin{array}{c}\text { Boys } \\
n=148\end{array}$}} & \multirow{2}{*}{\multicolumn{3}{|c|}{$\begin{array}{l}\text { Boys }^{1} \\
n=118\end{array}$}} & \multirow{2}{*}{\multicolumn{3}{|c|}{$\begin{array}{l}\text { Boys }^{2} \\
n=30\end{array}$}} & \multirow{2}{*}{\multicolumn{3}{|c|}{$\begin{array}{c}\text { Girls } \\
n=186\end{array}$}} & \multirow{2}{*}{\multicolumn{3}{|c|}{$\begin{array}{c}\text { Girls }^{1} \\
n=148\end{array}$}} & \multirow{2}{*}{\multicolumn{3}{|c|}{$\begin{array}{l}\text { Girls }^{2} \\
n=38\end{array}$}} \\
\hline & & & & & & & & & & & & & & & & & & \\
\hline & Mean & \pm & SD & Mean & \pm & SD & Mean & \pm & SD & Mean & \pm & SD & Mean & \pm & SD & Mean & \pm & SD \\
\hline \multicolumn{19}{|l|}{ 8-10- year-old } \\
\hline Weight (kg) & 33.6 & \pm & 5.8 & 31.6 & \pm & 5.9 & 41.4 & \pm & 5.3 & 33.1 & \pm & 4.7 & 31.0 & \pm & 4.4 & 41.1 & \pm & 5.8 \\
\hline Height $(\mathrm{cm})$ & 139.7 & \pm & 6.0 & 138.8 & \pm & 6.1 & 143.4 & \pm & 5.8 & 138.2 & \pm & 6.4 & 137.8 & \pm & 6.6 & 139.6 & \pm & 5.7 \\
\hline BMI $\left(\mathrm{kg} / \mathrm{m}^{2}\right)$ & 17.0 & \pm & 0.8 & 16.3 & \pm & 0.8 & 20.0 & \pm & 1.0 & 18.2 & \pm & 0.9 & 17.4 & \pm & 0.8 & 21.1 & \pm & 1.2 \\
\hline BMI z-score (min-max) & -2.54 & - & 1.78 & -1.63 & - & 3.54 & -0.97 & - & 2.74 & -1.89 & - & 4.12 & -2.16 & - & 1.97 & -1.15 & - & 3.12 \\
\hline Sum of Skinfold $(\mathrm{mm})$ & 33 & \pm & 10 & 28 & \pm & 8 & 54 & \pm & 19 & 39 & \pm & 12 & 33 & \pm & 10 & 64 & \pm & 20 \\
\hline FFMI $\left(\mathrm{kg} / \mathrm{m}^{2}\right)$ & 13.9 & \pm & 0.8 & 13.7 & \pm & 0.8 & 14.9 & \pm & 0.8 & 12.8 & \pm & 0.8 & 12.5 & \pm & 0.8 & 13.9 & \pm & 0.8 \\
\hline $\mathrm{FMI}\left(\mathrm{kg} / \mathrm{m}^{2}\right)$ & 3.1 & \pm & 0.8 & 2.6 & \pm & 0.7 & 5.1 & \pm & 1.4 & 5.4 & \pm & 1.1 & 4.9 & \pm & 1.0 & 7.2 & \pm & 1.7 \\
\hline SES (blue/white) \% & \multicolumn{3}{|c|}{$45 / 55$} & \multicolumn{3}{|c|}{$44 / 66$} & \multicolumn{3}{|c|}{$47 / 53$} & \multicolumn{3}{|c|}{$40 / 60$} & \multicolumn{3}{|c|}{$38 / 62$} & \multicolumn{3}{|c|}{$47 / 53$} \\
\hline $\mathrm{PA}(1 / 2 / 3) \%$ & \multicolumn{3}{|c|}{$7 / 31 / 62$} & \multicolumn{3}{|c|}{$7 / 30 / 63$} & \multicolumn{3}{|c|}{$9 / 38 / 53$} & \multicolumn{3}{|c|}{$9 / 44 / 47$} & \multicolumn{3}{|c|}{$8 / 42 / 50$} & \multicolumn{3}{|c|}{$10 / 51 / 39$} \\
\hline Tanner $(1 / 2 / 3 / 4 / 5) \%$ & \multicolumn{3}{|c|}{$100 / 0 / 0 / 0 / 0$} & \multicolumn{3}{|c|}{$100 / 0 / 0 / 0 / 0$} & \multicolumn{3}{|c|}{$100 / 0 / 0 / 0 / 0$} & \multicolumn{3}{|c|}{$71 / 28 / 1 / 0 / 0$} & \multicolumn{3}{|c|}{$80 / 20 / 0 / 0 / 0$} & \multicolumn{3}{|c|}{$38 / 57 / 5 / 0 / 0$} \\
\hline Energy intake (MJ/d) & 9.5 & \pm & 2.6 & 9.5 & \pm & 2.5 & 9.4 & \pm & 3.0 & 8.8 & \pm & 2.1 & 9.0 & \pm & 2.2 & 8.1 & \pm & 1.8 \\
\hline Carb intake $(\mathrm{g} / \mathrm{d})$ & 301.7 & \pm & 87.1 & 302.7 & \pm & 83.8 & 298.1 & \pm & 99.9 & 277.5 & \pm & 75.7 & 283.8 & \pm & 77.8 & 252.1 & \pm & 61.2 \\
\hline Fat intake $(\mathrm{g} / \mathrm{d})$ & 82.9 & \pm & 30.1 & 83.4 & \pm & 28.4 & 80.8 & \pm & 36.5 & 77.8 & \pm & 26.0 & 79.3 & \pm & 26.5 & 71.9 & \pm & 22.9 \\
\hline PROT intake $(\mathrm{g} / \mathrm{d})$ & 71.7 & \pm & 21.4 & 72.0 & \pm & 21.3 & 70.6 & \pm & 21.8 & 67.8 & \pm & 19.0 & 69.2 & \pm & 18.8 & 62.3 & \pm & 20.0 \\
\hline ARG intake $(\mathrm{g} / \mathrm{d})$ & 3.0 & \pm & 1.2 & 3.0 & \pm & 1.2 & 2.9 & \pm & 1.2 & 2.8 & \pm & 1.0 & 2.9 & \pm & 1.0 & 2.6 & \pm & 1.0 \\
\hline LYS intake $(\mathrm{g} / \mathrm{d})$ & 4.4 & \pm & 1.8 & 4.4 & \pm & 1.8 & 4.2 & \pm & 1.6 & 4.1 & \pm & 1.5 & 4.2 & \pm & 1.5 & 3.8 & \pm & 1.6 \\
\hline \multicolumn{19}{|l|}{ 14-16-year-old } \\
\hline Weight (kg) & 65.6 & \pm & 9.4 & 62.7 & \pm & 9.1 & 77.2 & \pm & 10.4 & 58.5 & \pm & 8.5 & 56.2 & \pm & 7.7 & 67.4 & \pm & 11.5 \\
\hline Height (cm) & 176.3 & \pm & 7.2 & 175.5 & \pm & 7.4 & 179.5 & \pm & 6.5 & 165.2 & \pm & 6.7 & 165.2 & \pm & 6.7 & 165.1 & \pm & 6.8 \\
\hline BMI $\left(\mathrm{kg} / \mathrm{m}^{2}\right)$ & 21.1 & \pm & 1.2 & 20.3 & \pm & 1.2 & 24.1 & \pm & 1.2 & 18.0 & \pm & 1.5 & 16.3 & \pm & 1.3 & 24.7 & \pm & 2.2 \\
\hline BMI z-score min-max & -1.16 & - & 3.15 & -1.21 & - & 2.89 & -0.95 & - & 2.54 & -1.56 & - & 2.30 & -2.33 & - & 1.34 & -1.21 & - & 3.98 \\
\hline Sum of Skinfold (mm) & 35 & \pm & 18 & 30 & \pm & 14 & 55 & \pm & 32 & 52 & \pm & 15 & 48 & \pm & 13 & 70 & \pm & 23 \\
\hline FFMI $\left(\mathrm{kg} / \mathrm{m}^{2}\right)$ & 17.8 & \pm & 1.2 & 17.5 & \pm & 1.2 & 19.0 & \pm & 1.2 & 13.5 & \pm & 1.4 & 12.5 & \pm & 1.3 & 17.5 & \pm & 1.9 \\
\hline $\mathrm{FMI}\left(\mathrm{kg} / \mathrm{m}^{2}\right)$ & 3.3 & \pm & 1.2 & 2.8 & \pm & 1.2 & 5.1 & \pm & 1.2 & 4.5 & \pm & 1.6 & 3.8 & \pm & 1.3 & 7.2 & \pm & 2.6 \\
\hline
\end{tabular}

$\mathrm{BMI}=$ body mass index, ${ }^{1} \mathrm{BMI}$-quintiles $1-4,{ }^{2} \mathrm{BMI}$-quintile $5, \mathrm{ARG}=$ arginine, LYS $=$ lysine, FFMI= Fat Free Mass Index, FMI= Fat Mass Index, Carb= carbohydrate

\section{Power calculation}

A power calculation is verified, based on a number of 334 subjects, a two-sided significance level of 0.05 and a population correlation $(\rho)$ between protein intake and body fat $\%$ of 0.14 for $8-10$ y old children ${ }^{13,14}$. Using the equation for a regression analysis design, a power of $78 \%$ was calculated.

\section{Statistical analysis}

Each dietary and anthropometric variable was treated as a continuous variable. To improve the normality of their distribution, ARG, LYS and ESF were logarithmically transformed. The relationship between intakes of PROT and more specific ARG or LYS at age 9 year and $\triangle \mathrm{FMI}$ or $\triangle \mathrm{FFMI}$ was assessed by a multiple regression model including baseline FFMI or FMI, age, energy intake, physical activity, SES, and puberty-stage as covariates. The interaction of ARG with LYS was estimated in a model with the same covariates as the model described before. This model was converted to the final regression model, by division of LYS into low and high LYS intake. Low LYS-intake was defined as LYS intakes below the median, and high LYSintake as LYS intakes above the median. After analysing data of boys and girls, we divided boys and girls on BMI in either the $1-4^{\text {th }}$ quintile or the $5^{\text {th }}$ quintile. To test 
the significance of the contribution of the variables, an F-test was used. All values are expressed as mean \pm SEM.

A p-value $<0.05$ was considered as indicating statistical significance. All statistical analyses were performed using SPSS for WINDOWS, version 14.0; SPSS, Chicago, IL.

\section{RESULTS}

The characteristics of the children, grouped by study year, gender and quintile of BMI are shown in Table 1.

The results are summarized in Table 2 , with $\Delta \mathrm{FMI}$ and $\triangle \mathrm{FFMI}$ as dependent variables and habitual intakes of protein as well as the specific amino acids ARG, LYS as independent variables. Adjustments were made for baseline FMI or FFMI, age, energy intake, physical activity, SES and puberty-stage.

\section{Association between intakes of protein, and specifically ARG and LYS intakes and changes in FMI and FFMI}

Boys

Overall no significant associations were found for protein or for ARG or LYS intake and $\triangle \mathrm{FMI}$ or $\triangle \mathrm{FFMI}$ (Table 2).

\section{Girls}

The crude as well as the adjusted models showed associations between intakes of LYS and $\triangle \mathrm{FMI}(\beta=-1.16 \pm 0.56 \mathrm{p}=0.04)$ (Table 2$)$.

When dividing the girls according to BMI-quintiles, associations between PROT intake and $\Delta \mathrm{FMI}(\beta=-1.22 \pm 0.56 p=0.03)$, as well as ARG or LYS intake and $\triangle F M I$ ( $\beta$ $=-1.10 \pm 0.53 p=0.04, \beta=-1.13 \pm 0.51 p=0.03$ respectively) were found among those with a BMI in the $1-4^{\text {th }}$ quintile (lean) (Table 2 ).

High PROT intake was positively associated with $\triangle \mathrm{FFMI}$ in girls with a BMI in the $5^{\text {th }}$ quintile $(p=0.04)$ (Table 2$)$. In this group of girls, a stronger positive association was found between ARG intake and $\triangle F F M I$ when LYS intake was high (LYS intake above median), than when LYS intake was low (LYS intake below median) ( $\beta=8.87 \pm 0.52, \beta$ $=-3.53 \pm 4.65$ respectively) $(p=0.04)$. 
Table 2: Adjusted models showing the associations between both ARG and LYS(g/day) intakes and changes is $\mathrm{FMI}$ and $\mathrm{FFMI}\left(\mathrm{kg} / \mathrm{m}^{2}\right)$

\begin{tabular}{|c|c|c|c|c|c|c|c|c|c|c|}
\hline & & \multicolumn{3}{|c|}{ Boys } & \multicolumn{3}{|c|}{ Boys $^{1}$} & \multicolumn{3}{|c|}{ Boys $^{2}$} \\
\hline & & $\beta$ & SE & $p$ & $\beta$ & SE & $p$ & $\beta$ & SE & $p$ \\
\hline \multirow[t]{3}{*}{$\mathrm{FMI}\left(\mathrm{kg} / \mathrm{m}^{2}\right)$} & PROT & 0.11 & 0.55 & 0.84 & 0.17 & 0.47 & 0.72 & -0.4 & 2.76 & 0.89 \\
\hline & ARG & -0.32 & 0.49 & 0.56 & -0.49 & 0.47 & 0.30 & -0.90 & 2.01 & 0.66 \\
\hline & LYS & 0.20 & 0.51 & 0.62 & -0.45 & 0.42 & 0.29 & -0.99 & 1.81 & 0.59 \\
\hline \multirow[t]{5}{*}{ FFMI $\left(\mathrm{kg} / \mathrm{m}^{2}\right)$} & PROT & 0.27 & 0.62 & 0.67 & 0.16 & 0.63 & 0.81 & 0.00 & 2.66 & 1.00 \\
\hline & ARG & 0.21 & 0.63 & 0.74 & 0.01 & 0.48 & 0.99 & 2.34 & 1.80 & 0.20 \\
\hline & LYS & 0.12 & 0.57 & 0.84 & 0.15 & 0.47 & 0.75 & 2.01 & 1.54 & 0.20 \\
\hline & & \multicolumn{3}{|c|}{ Girls } & \multicolumn{3}{|c|}{ Girls $^{1}$} & \multicolumn{3}{|c|}{ Girls $^{2}$} \\
\hline & & $\beta$ & SE & $p$ & $\beta$ & SE & $p$ & $\beta$ & SE & $p$ \\
\hline \multirow[t]{3}{*}{ FMI $\left(\mathrm{kg} / \mathrm{m}^{2}\right)$} & PROT & -0.92 & 0.64 & 0.15 & -1.22 & 0.56 & 0.03 & -3.21 & 2.72 & 0.25 \\
\hline & ARG & -1.12 & 0.60 & 0.06 & -1.10 & 0.53 & 0.04 & -0.22 & 2.57 & 0.93 \\
\hline & LYS & -1.16 & 0.56 & 0.04 & -1.13 & 0.51 & 0.03 & -0.29 & 2.27 & 0.90 \\
\hline \multirow[t]{3}{*}{ FFMI $\left(\mathrm{kg} / \mathrm{m}^{2}\right)$} & PROT & 0.06 & 0.53 & 0.90 & 0.24 & 0.50 & 0.64 & 3.99 & 1.87 & 0.04 \\
\hline & ARG & 0.20 & 0.51 & 0.70 & 0.13 & 0.68 & 0.85 & 0.27 & 1.84 & 0.89 \\
\hline & LYS & 0.06 & 0.48 & 0.90 & 0.07 & 0.61 & 0.91 & 0.54 & 1.64 & 0.75 \\
\hline
\end{tabular}

${ }^{1}$ BMI-quintiles 1-4th, ${ }^{2}$ BMI-quintile $5^{\text {th }}, \mathrm{ARG}=$ arginine, LYS $=$ lysine, FFMI= Fat Free Mass Index, $\mathrm{FMI}=$ Fat Mass Index

\section{DISCUSSION}

The present study shows that in girls dietary protein and the specific amino acids ARG and LYS may have influenced the development of body composition during puberty development.

Higher intakes of protein and specifically the amino acids ARG or LYS, were associated with less gain in FM over 6 years among 9 year old lean girls. This observations are in accordance with somatotropic effects of protein and the specific amino acids ARG and LYS ${ }^{4-6}$, which may result in decreased serum levels of triglycerides and relative amount of $\mathrm{FM}^{7,15}$.

A high protein intake was associated with the biggest increase in FFMI in girls with a BMI in the $5^{\text {th }}$ quintile. This may be explained by the stimulating effects of proteins and $A A$ on muscle protein synthesis ${ }^{16}$, which, in turn, may partially be mediated by the $\mathrm{GH}$-stimulating properties of proteins and $\mathrm{AA}$ combined, but not when the AA were consumed separately ${ }^{5}$.

The association between $\triangle \mathrm{FMI}$ and the intake of ARG or LYS, as well as interactions between ARG and LYS on $\triangle F F M I$ suggest that the effects of proteins may depend on the available amount and combination of specific AA, such as ARG and LYS. The somatotropic regulation of growth could thus be modulated by privileged AA.

The described associations were found to be significant among girls only, although the associations in boys were in general in the same direction. The stronger associations could be explained by gender-differences in body composition development among pubertal children. Girls' FFM continue to increase until the age of 15y, 
FM until 17 year. In boys FFM increases until 19 year and FM decreases after 13 year. Since the children in our study were measured at age 8-10 year and 14-16 year, it is plausible that gender-differences in the development of body composition influenced outcomes.

In this study, the mean intake per day of protein was $70 \pm 21 \mathrm{gram} /$ day $(2.1$ gram $/ \mathrm{kg} /$ day), which is considerably above the requirement of $0.95 \mathrm{~g} / \mathrm{kg} / \mathrm{day}$ [NHANES III]. ARG and LYS intake per day were in accordance with requirements for adults [NHANES III]. ARG and LYS concentrations are both high in products like milk, meat and fish. Nuts and seeds consist of large amounts of ARG. Beef and cheese contains high amounts of LYS. The present study found that a high intake of ARG combined with high intakes of LYS was associated with the maximum increase in FFMI during growth. Such a diet may be composed by a high consumption of the above mentioned products.

The dietary assessment method has some incorporated problems and it should be noted that measurement error may have occurred by using a $24 \mathrm{~h}$ recall method, as also indicated by the relatively low total energy intake and fat intake among the children within the highest BMI quintile, compared with the leaner girls. However, other studies have shown that although energy intake may be underreported in obese subjects, protein reporting seems relatively more accurate ${ }^{17-19}$.

The advantage of $24 \mathrm{~h}$ recall methods above 3-day food records, is the person contact that contributes to the reliability of the collected data. There is no literacy requirement and the respondent burden is relatively small. The administration time is short and the procedure does not alter food intake patterns. The disadvantage of recall methods is the under and over estimation of portion size ${ }^{20}$. For the quantification of portion sizes a picture book, including country-specific dishes, with additional household measures and other relevant measurements is recommended. In our study, portion size is estimated using common household measures and food pictures, as is described in the method section, in order to reduce the under and over estimation. The $24 \mathrm{~h}$ dietary recall is validated in several studies, with doubly labelled water, and have been shown to be representative of energy expenditure in children ${ }^{18,21}$. Furthermore in third grade children, the $24 \mathrm{~h}$ recall method was validated with observational data collected at the same moment as the $24 \mathrm{~h}$ recall ${ }^{22}$ and with a 3 days dietary record ${ }^{23}$. The $24 \mathrm{~h}$ recall provide a relatively good characterization of the population's average nutrient intake ${ }^{24}$, as is also found in our sample. In the present study, the means as well as tenth and ninetieth percentile intakes of energy and macronutrients were of the same magnitude as those reported by children (7-10 years) and adolescents (15-18 years) in the Danish nationwide survey (1995) in spite of the fact that the nationwide survey used a 7 days estimated diet record ${ }^{25}$. The estimation of the energy intake with the equation of Harris and Benedict, multiplied by a physical activity level of 1.7 results in an energy intake of the same magnitude as the reported energy intake in the present study. 
However, there is day-to day variation in our dietary pattern, which can influence the results of the $24 \mathrm{~h}$ recall. We agree that this is a limitation of the $24 \mathrm{~h}$ recall, however we were particularly interested in the protein intake, which is known to have a lower variation between days ${ }^{26}$. Especially fibre intake and cholesterol intake showed a day to day variation ${ }^{24}$. Hence, the $24 \mathrm{~h}$ recall method used in the present study seems adequate in relation to the estimation of dietary protein intake.

The results of the present study may suggest that a physiological role of protein intake may depend on the amount and the combination of specific amino acids. This may add to our understanding of how to perform future dietary intervention on the regulation of body composition, even if this has to be further investigated by experimental designs.

In conclusion, among girls high intakes of protein may decrease body fat gain and increase fat free mass gain. The influence of a high protein intake seems furthermore dependent on the available amounts and combinations of the specific amino acids ARG and LYS. 


\section{REFERENCES}

1. Snel YE, Brummer RJ, Doerga ME, Zelissen PM, Bakker CJ, Hendriks MJ \& Koppeschaar HP. Adipose tissue assessed by magnetic resonance imaging in growth hormone-deficient adults: the effect of growth hormone replacement and a comparison with control subjects. Am J Clin Nutr 199561 1290-1294.

2. Buijs MM, Burggraaf J, Langendonk JG, Schoemaker RC, Frolich M, Arndt JW, Cohen AF, Romijn JA, Ackermans MT, Sauerwein HP, Meinders AE \& Pijl H. Hyposomatotropism blunts lipolysis in abdominally obese women. J Clin Endocrinol Metab 200287 3851-3858.

3. Rabinowitz D, Merimee TJ, Maffezzoli R \& Burgess JA. Patterns of hormonal release after glucose, protein, and glucose plus protein. Lancet 19662 454-456.

4. van Vught AJ, Nieuwenhuizen AG, Brummer RJ \& Westerterp-Plantenga MS. Effects of oral ingestion of amino acids and proteins on the somatotropic axis. J Clin Endocrinol Metab 200893 584-590.

5. Isidori A, Lo Monaco A \& Cappa M. A study of growth hormone release in man after oral administration of amino acids. Curr Med Res Opin 19817 475-481.

6. Knopf RF, Conn JW, Fajans SS, Floyd JC, Guntsche EM \& Rull JA. Plasma Growth Hormone Response to Intravenous Administration of Amino Acids. J Clin Endocrinol Metab 196525 1140-1144.

7. Speyckerelle $Y$, Herberth B \& Deschamps JP. Dietary behavior of an adolescent french male population. $J$ Hum Nutr Diet 19925 161-168.

8. Riddoch CJ ED, van Mechelen W, et al. European Youth Heart Study. Protocols Manual. 2004a.

9. Riddoch CJ ED, van Mechelen W, et al. European Youth Heart Study. Background., 2004b.

10. Moller A. Food composition tables (in Danish) Saxholt E Copenhagen National Food Agency of Denmark 1996.

11. Wedderkopp N. Atherosclerotic cardiovascular risk factors in Danish children and adolescents. A community based approach with a special refeerence to physical fitness and obesity, PhD Thesis, Institute of Sport Science and Clinical Biomechanics, Faculty of Health Sciences, University of Southern Denmark. 2001.

12. Slaughter MH, Lohman TG, Boileau RA, Horswill CA, Stillman RJ, Van Loan MD \& Bemben DA. Skinfold equations for estimation of body fatness in children and youth. Hum Biol 198860 709-723.

13. Hoppe C, Molgaard C, Juul A \& Michaelsen KF. High intakes of skimmed milk, but not meat, increase serum IGF-I and IGFBP-3 in eight-year-old boys. Eur J Clin Nutr 200458 1211-1216.

14. Hoppe C, Molgaard C, Thomsen BL, Juul A \& Michaelsen KF. Protein intake at 9 mo of age is associated with body size but not with body fat in 10-y-old Danish children. Am J Clin Nutr 200479 494-501.

15. Fu WJ, Haynes TE, Kohli R, Hu J, Shi W, Spencer TE, Carroll RJ, Meininger CJ \& Wu G. Dietary L-arginine supplementation reduces fat mass in Zucker diabetic fatty rats. J Nutr 2005135 714-721.

16. Flakoll P, Sharp R, Baier S, Levenhagen D, Carr C \& Nissen S. Effect of beta-hydroxy-beta-methylbutyrate, arginine, and lysine supplementation on strength, functionality, body composition, and protein metabolism in elderly women. Nutrition 200420 445-451.

17. Heitmann BL \& Lissner L. Dietary underreporting by obese individuals--is it specific or non-specific? $B m j$ 1995311 986-989.

18. Bandini LG, Cyr H, Must A \& Dietz WH. Validity of reported energy intake in preadolescent girls. Am J Clin Nutr 199765 1138S-1141S.

19. Maffeis C, Schutz Y, Zaffanello M, Piccoli R \& Pinelli L. Elevated energy expenditure and reduced energy intake in obese prepubertal children: paradox of poor dietary reliability in obesity? J Pediatr 1994124 348-354.

20. Biro G, Hulshof KF, Ovesen L \& Amorim Cruz JA. Selection of methodology to assess food intake. Eur J Clin Nutr 200256 Suppl 2 S25-32.

21. Livingstone MB \& Robson PJ. Measurement of dietary intake in children. Proc Nutr Soc 200059 279-293.

22. Lytle LA, Nichaman MZ, Obarzanek E, Glovsky E, Montgomery D, Nicklas T, Zive M \& Feldman H. Validation of 24-hour recalls assisted by food records in third-grade children. The CATCH Collaborative Group. $J$ Am Diet Assoc 199393 1431-1436.

23. Beer-Borst $S \&$ Amado R. Validation of a self-administered 24-hour recall questionnaire used in a largescale dietary survey. Z Ernahrungswiss 199534 183-189. 


\section{CHAPTER 7}

24. Posner BM, Martin-Munley SS, Smigelski C, Cupples LA, Cobb JL, Schaefer E, Miller DR \& D'Agostino RB. Comparison of techniques for estimating nutrient intake: the Framingham Study. Epidemiology 19923 171-177.

25. Andersen NL, Fagt S, Groth MV \& al. e, Eds. Danish dietary habits 1995 (In Danish with a summary in English). . 1996.

26. Plummer M \& Kaaks R. Commentary: An OPEN assessment of dietary measurement errors. Int J Epidemiol 200332 1062-1063. 


\section{8}

\section{Pharmacological and}

physiological growth hormone stimulation tests to predict successful GH therapy in children

ANNEKE J.A.H. VAN VUGHT, ARIE G. NIEUWENHUIZEN, WILLEM-JAN GERVER, MARGRIET A.B. VELDHORST, ROBERT-JAN M. BRUMMER, MARGRIET S. WESTERTERP-PLANTENGA.

JOURNAL OF PEDIATRIC ENDOCRINOLOGY \& METABOLISM, 2009 IN PRESS 


\section{ABSTRACT}

Although the current use of growth hormone (GH) stimulation tests (GHST) is still subject to debate, the tests are widely used to diagnose GH deficiency. This literature review evaluates primarily the sensitivity, specificity and reliability of GHST and secondarily their convenience. The single pharmacological tests typically address only a single pathway in the complex physiological regulation of GH secretion and are therefore characterized by lower sensitivity, specificity and reliability than the combined pharmacological tests or physiological tests. In spite of the high levels of sensitivity, specificity and reliability, physiological tests require considerably more effort to perform, from the physician as well as from the child. Therefore, a need for an alternative, convenient, physiological GHST still remains. Oral ingestion of dietary protein is practically convenient and may induce more physiological stimulation of $\mathrm{GH}$ secretion, hence may be a promising valuable addition to the existing GHSTs in GH deficiency. 


\section{INTRODUCTION}

Growth hormone $(\mathrm{GH})$ stimulation tests are widely used to diagnose $\mathrm{GH}$ deficiency (GHD). The aetiology of GHD in children varies from the complete absence of growth hormone, leading to severe growth retardation, to a partial deficiency, leading to short stature ${ }^{1,2}$. The cause of GHD may be congenital or acquired. Congenital abnormalities range from neuro-endocrine dysfunction of $\mathrm{GH}$ secretion to isolated growth failure, with unknown aetiology. Acquired causes are a range of hypothalamic-pituitary axis insults, including tumours ${ }^{3}$. The exact definition of GHD remains controversial. In short and poorly growing children, GH secretion varies between a negligible GH secretion to a high GH secretion. An arbitrary, non scientific border was set between GHD and non-GHD as is described below.

Children with GHD usually present with short stature and low growth velocity for their age and pubertal stage ${ }^{4}$. It can be difficult to diagnose GHD, because of its variety in grades of severity, its broad space of physiological level and the fact that $\mathrm{GH}$ release is influenced by many factors such as age, pubertal stage, body fat mass, caloric intake and emotional stage ${ }^{5,6}$.

In October 1999 in Eilat, Israel, the Growth Hormone Research Society (GHRS) formulated Consensus guidelines used for diagnosing and treatment of children with GHD. In these guidelines, the diagnosis of GHD in childhood is defined as a multifaceted process requiring comprehensive auxological and clinical assessment, combined with radiological evaluation and biochemical tests of the $\mathrm{GH}$ - Insulin-like growth factor-1 (IGF-1) axis (also called GH stimulation tests (GHSTs)), as described below ${ }^{7}$.

Auxological assessment is based on parental height and growth velocity. Clinical assessment could involve the use of Magnetic Resonance Imaging (MRI) to identify abnormalities in the hypothalamic-pituitary region. Genetic disorders also have to be taken into account ${ }^{7}$. Radiological ( $x$-ray) evaluation of the bone age should be used as part of the routine evaluation of children with growth failure over $1 \mathrm{yr}$ of age.

Biochemical tests (i.e. single pharmacological GHSTs) are tests to evaluate the GH secretion capacity. These tests should be performed after an overnight fast using a standardized protocol. A canula is inserted in a vein and after $30 \mathrm{~min}$ the stimulating agent is administered orally or intravenously, dependent on the agent. Blood is sampled every 15 or $30 \mathrm{~min}$ for 3 hours. Stimulating agents include arginine, clonidine, glucagon, insulin and levo-dopamine. According to the Consensus, the diagnosis of GHD requires the traditionally peak GH concentration below $10 \mu \mathrm{g} / \mathrm{L}$ by radioimunnoassay (RIA), however the GHRS also mention the critics on this cutpoint as the overlap between GHD and non-GHD in GH responses after GHSTs. In suspected GHD, without clear patho-physiological cause, two GH stimulation tests are required, whereas one suffices in children with a central nervous system pa- 
thology, history of irradiation, multiple pituitary hypothalamic diseases or genetic defect. The use of 22-kDA hGH assay with monoclonal antibodies is recommended, to determine serum $\mathrm{GH}$ concentrations ${ }^{7}$.

In the absence of a gold standard, it is important for the clinician to integrate all available data before diagnosing, in order to prevent misdiagnosis and unnecessary, expensive therapy ${ }^{8}$. Although the use of GHSTs as biochemical tests to diagnose GHD has been a subject of debate for a long time, nevertheless, GHSTs are still essential instruments in diagnosing GHD, because there are no better alternatives available for evaluation of $\mathrm{GH}$ secretion ${ }^{7,9,10}$.

This review describes literature reports of pharmacological and physiological GHSTs used in practical settings, and assesses them in terms of sensitivity, specificity, reliability and convenient for use in practice. First the requirements for GHSTs are described, followed by an overview of the current available tests, assessed in terms of the requirements. The outcomes are discussed, followed by a proposal for a new physiological GHST.

\section{REQUIREMENT OF GHSTS}

Requirements for GHSTs include primarily a high validity (sensitivity and specificity), reliability and secondarily convenience to use in practice. Each requirement is defined in this sectionand in the next sectionthe requirements are used to assess GHSTs.

A valid test is defined as a test which measures what it is supposed to measure. A test must have an agreement with the diagnosis, as regulated by other measures or standards ${ }^{11,12}$. In this review, validity is assessed by the specificity and sensitivity of a test. The sensitivity of the test is calculated as the number of children diagnosed with GHD who have a positive test result (the cut-off level is not exceeded in a child diagnosed with GHD) divided by the total number of children diagnosed with GHD. Specificity is the number of non-GHD children who have a negative test (the cut-off level is exceeded in a child defined as non-GHD) divided by the total number of children diagnosed as non-GHD. Sensitivity and specificity are expressed as percentages.

Reliability is defined as the consistency of a set of measurements or a measuring instrument. A reliable test will show the same result when the same test is repeated in the same subject on multiple occasions ${ }^{11}$. Reliability is expressed as percentages of identical diagnose, as well as correlation coefficients (CC) and coefficients of variation (CV). The CV and CC seem to be more suitable for the evaluation of reliability than the percentage of identical diagnose because they are independent of the arbitrary cut-off levels. 
In addition, convenience to use in practice is a general term, which includes the costs of the test, the duration and time spent by the doctor to perform the GHSTs as well as the impact on the child and the time it takes for the child to undergo the GHSTs in the hospital, preparations at home, invasivity and side-effects.

\section{DESCRIPTION AND ASSESSMENT OF THE TESTS}

Many different GHSTs have been used in children. Sizonenko et al. ${ }^{3}$ described at least 34 GHSTs that have been proposed and executed in 189 different combination protocols. The most common GHSTs and their characteristics are listed in table 1.

Many studies have been performed to assess the validity (sensitivity and specificity) and reliability of pharmacological and physiological GHSTs. Their results are summarized in Table 2. We assessed seven single stimulation tests (arginine (ARG), insulin-induced hypoglycaemia (ITT), clonidine, Levo-Dopamine, Growth Hormone Releasing Hormone (GHRH), propranolol, glucagon) as well as 2 combined stimulation tests (GHRH + propranolol, ARG + GHRH) and 2 physiological tests (sleep, exercise). The table shows details of each study, as used cut-off levels, assay used and handling of pubertal status, as well as the definition of GHD used in each study (reference value). In the assessment of validity, the definition of GHD used in the study is important, since the definition is the reference value for calculating sensitivity and specificity. Studies have defined GHD differently, varying from GH concentrations below $7 \mu \mathrm{g} / \mathrm{L}$ after ITT to a multiple diagnosis including clinical and biochemical measurements. Because of the inconsistency in the definition of GHD, as well as the inconsistency in cut-off levels used, assays used, and population (different ages, puberty stages and way to handle with priming), it is difficult to compare studies statistically in terms of sensitivity and specificity.

Although comparisons between studies are difficult, the ITT is widely described as the most sensitive and specific single stimulating test ${ }^{13}$. When comparing two tests with identical cut-off levels and definitions used to diagnose GHD, the ARG-test is more sensitive and specific than the clonidine test ${ }^{14,15}$. A very high validity of the clonidine test was found by Silva et al. and Zadik et al. ${ }^{16,17}$. This high validity in the study by Silva et al. is caused by the fact that these authors testing studypopulations consisting of children with congenital GHD who showed very low GH concentrations ${ }^{16}$. The sensitivity of glucagon and Levo-Dopamine tests has not been tested as frequently. The specificity of the glucagon test is comparable with that of the ARG test and the specificity of the Levo-Dopamine test is comparable with that of the ITT, as was found by Ghigo et al. ${ }^{18}$.

Tests combining 2 stimulators, such as GHRH + ARG or pyridostigmine + GHRH are characterized by a high sensitivity and specificity ${ }^{13,18}$ compared with the single stimulation tests. The physiological sleep test shows a higher validity than the ARG 
test and is comparable in validity with the ITT ${ }^{19,20}$. The physiological exercise test shows a high sensitivity, but a low specificity ${ }^{21}$. Various studies have shown that increasing the cut-off level decreases the specificity of single stimulation tests and increases the sensitivity of the tests. However, the specificity of combined stimulating tests changes less by varying the cut-off levels. The most appropriate cut-off level of a test could be that which induces the highest sum of sensitivity and specificity, however this cut-off level seems to be different for each individual GHST ${ }^{12,18 \text {, }}$ 21,22 . Overall, the sensitivity and specificity of the GHSTs seem to be better in the combined pharmacological stimulation tests and sleep tests, compared with the single pharmacological stimulation tests.

Reliability of the GHSTs is shown in Table 3. We assessed six single stimulation tests (ARG, ITT, clonidine, Levo-Dopamine, ornithine, glucagon), 2 combined stimulation tests (ARG + ITT, glucagon-propranolol) and 2 physiological tests (sleep, continuous blood-sampling). The table shows details of each study, such as the cut-off level used, type of assay used, pubertal status at the first test and the time between the first test and the second test (retest). Overall the single GHSTs show a wide range of reliability outcomes; the coefficient of variation is high, while the percentage of identical diagnose and the regression coefficient between the two repeated tests are low, regardless of the time between test and retest ${ }^{9,23-31}$. The reliability of the GHSTs seems to be better in physiological tests than in single pharmacological tests ${ }^{17,27,28,31-34}$.

With respect to convenient use of the tests in practice, the effort from the physician and the effort from the patient, including side effects for the patient were evaluated. The characteristics of the tests are summarized in table 1 . The single stimulation tests are characterized by a short duration, from 90 to 120 minutes (table 1 ). The exercise test also takes no more than 120 minutes ${ }^{18,21}$. The sleep test and the 12 or $24 \mathrm{~h}$ physiological $\mathrm{GH}$-secretion test required an overnight admission ${ }^{32}$. Moreover, multiple sampling is inconvenient and time consuming ${ }^{20,35}$. Although no side-effects of these physiological tests are mentioned ${ }^{20,21}$, the single pharmacological GHSTs as well as the combined GHSTs however are well-known to induce side effects, such as hypoglycaemia, hypokalaemia, hypertension, nausea and vomiting $14,20,32,33,36$, although not in all studies these side effects are reported. Several countries do not perform the ITT because of its dangerous adverse effects; severe hypoglycaemia and hypokalemia which may induce cardiac arrhythmia ${ }^{37}$. Furthermore, single and combined stimulation tests require preparations for the patient at home, for instance no food intake is allowed during the night and in the morning before the test. Such preparations are not needed to perform the physiological tests.

For the physician, the physiological tests require more effort, as the patients has to stay in hospital overnight. In addition the physiological sleep test and 12-24 h continuous blood sampling test are quite expensive, because of the hospitalisation and the assays required for multiple samples $32,33,38$. The exercise test is difficult to perform, because the level of exhaustion is arbitrary ${ }^{21}$. 


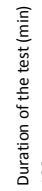

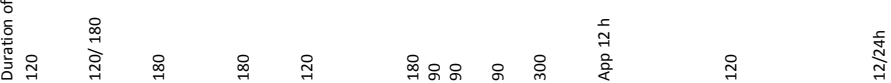

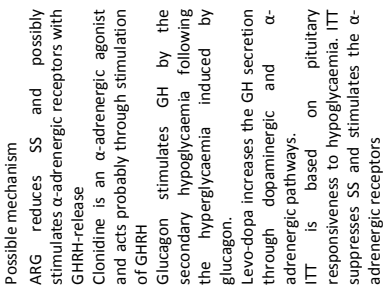

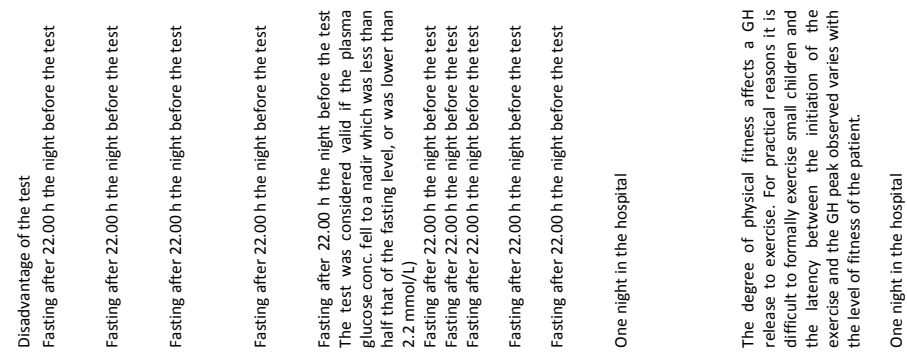

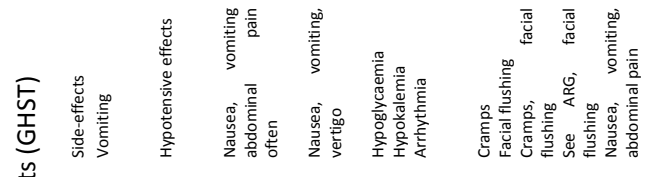

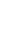

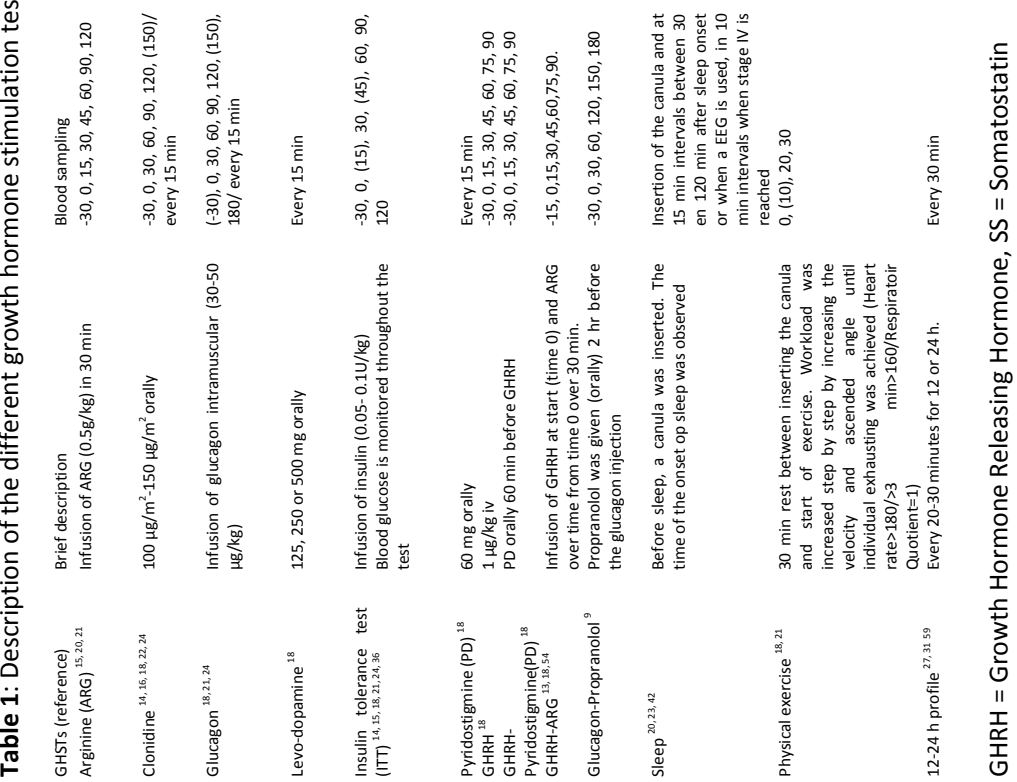




\section{GHSTS UNDER DEBATE}

The previous sectionreported higher validity and reliability of combined stimulation tests and physiological tests (sleep-test, 12-24h continuous blood sampling tests), compared with the single pharmacological stimulation tests, although the comparison between the tests are problematic due to the use of different protocols and target-groups. This sectiondiscusses the main criticisms on current used single pharmacological GHSTs (arginine, clonidine, glucagon, insulin and Levo-dopamine), a combined pharmacological test (GHRH+ARG) and physiological GHST (sleep test, exercise test, 12-24h sampling). We first discuss general criticisms, followed by specific criticisms on the single pharmacological test, combined pharmacological tests and physiological tests.

\section{General criticisms}

Using GHSTs in general raises problems. Firstly, the cut-off level of GHconcentration to distinguish between non-GHD and GHD is arbitrary, since there is

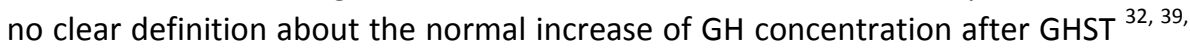
${ }^{40}$. For instance, some children grow perfectly well with a maximum peak of $7 \mu \mathrm{g} / \mathrm{L}$ 31, 41 after a single pharmacological stimulation test, while poor or delayed growing children could have a maximum peak of $12 \mu \mathrm{g} / \mathrm{L}$ with the same test. From table 2 it becomes clear how cut-off levels determine the sensitivity and specificity of the test ${ }^{11}$. Each test, however, has its own mechanism to stimulate $\mathrm{GH}$ secretion and therefore should need a matched cut-off level to distinguish between GHD and non-GHD ${ }^{9,10,36}$. Conversion factors to transfer from one test to the other test may be necessary to make test-outcomes comparable ${ }^{10}$. The current arbitrary cut-off level used by the GHRS of $10 \mu \mathrm{g} / \mathrm{L}$ seems to be insufficient to distinguish non-GHD from GHD children with the currently used pharmacological GHSTs.

Secondly, there are variations in the measurement of GH concentrations in serum, resulting in a different diagnosis from the same sample due to the use of different assays, analyses in different laboratories and variety in unit conversion factor $(\mathrm{mU} / \mathrm{L} \text { to } \mathrm{mcg} / \mathrm{L})^{42-45}$. One of the causes of these variations is the use of various protocols of immunoassays regarding the interacting assay component ${ }^{33}$. A mixture of antibodies with different affinity and specificity for the GH molecule is used in a polyclonal assay while a monoclonal assay uses either one or two monoclonal antibodies. As a result, total concentration of $\mathrm{GH}$ measured by a polyclonal assay and a monoclonal assay may not be equal ${ }^{46}$. Moreover, half of $\mathrm{GH}$ in the circulation is bound to binding proteins which can interfere with the result and give either falsely high or falsely low GH readings, depending on the type of assay ${ }^{6,46}$. An example is given by a study from Levin et al., in which six of the samples showing normal results $(>10 \mu \mathrm{g} / \mathrm{L}$ ) measured with the polyclonal radioimmunoassay, were 
classified as GHD (<10 $\mu \mathrm{g} / \mathrm{L})$ based on the results from a Hybritech radioimmunoassay ${ }^{46}$. The newer assays, for instance immunofunctional assay (IFA), can give GH concentrations 2-3 times lower than the older immunoradiometric assay (IRMA), including magnetic immunoassay (MIA) and radio immunoassay (RIA) ${ }^{16,44}$. For the newer assays, the right border should be found ${ }^{47}$. Although the $\mathrm{GH}$ Research Society recommends an assay which measures $22-\mathrm{kDa} \mathrm{GH}$ and uses monoclonal antibodies ${ }^{7,45,48}$, there are still various $\mathrm{GH}$ assays used for the analysis of $\mathrm{GH}$ concentrations.

Thirdly, several factors influencing $\mathrm{GH}$ secretion may affect the results of the GHSTs, for example age, puberty, weight, stress, but also metabolic status and extent of spontaneous GH secretion before testing ${ }^{18,39,43}$. Several studies reported that children who failed to increase their $\mathrm{GH}$-concentrations above cut-off values with GH stimulation tests, showed normal responses after administration of sex steroids or after spontaneous puberty ${ }^{32,33,49}$. Priming with sex steroids could reduce the amount of misdiagnosed patients with more than $50 \%{ }^{50}$, however, if $\mathrm{GH}$ secretion becomes normal after priming, it would be unclear whether to treat the patient or not, since the cause of deficiency cannot be clearly indentified ${ }^{23}$. The current Consensus of the GHRS does not give clarity about priming in pre-puberty ${ }^{7}$. Besides stage of puberty, also age is a factor influencing $\mathrm{GH}$ secretion ${ }^{51}$. Furthermore the amount and distribution of fat-mass and fat-free-mass influence GH secretion ${ }^{9,10}$. Stress, as emotional deprivation, is another important factor decreasing GH concentrations in children. Furthermore, the time interval since the last spontaneous $\mathrm{gGH}$ peak is influencing the responste to GHST, for instance if there has been a $\mathrm{GH}$ peak shortly before the test, the response on the test is blunted ${ }^{10}$. Finally the metabolic status of the child is important when interpreting the GH concentration after a GHSTs. In single and combined stimulation tests, a child has to be fasted before and during the test.

\section{Single pharmacological tests}

Besides the general difficulties in distinguishing non-GHD from GHD, pharmacological tests have some specific issues. Single pharmacological stimulation tests do not present normal secretion dynamics and are non-physiological. Each stimulator has its own mechanism of influencing the $\mathrm{GH}$ secretion ${ }^{3,52}$ which results in different ways of artificial and non-physiologic stimulation ${ }^{43}$ and in discordant results when different tests are used in the same patients ${ }^{3,11}$. For instance, when a patient shows a low GH-response to a clonidine-test, where the mechanism is probably via $\mathrm{GHRH}$, it can not be presumed that the GH response to an arginine-test (where the mechanism is probably via suppression of somatostatin) is also diminished. 


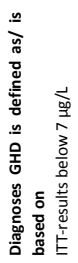

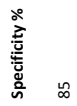

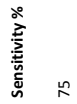

竞

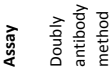
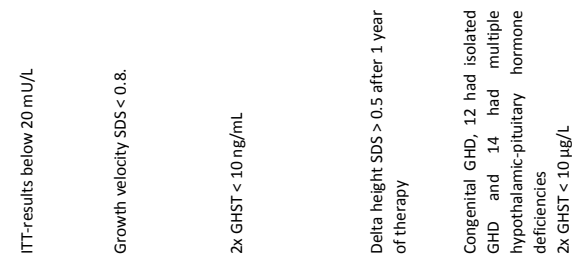

童

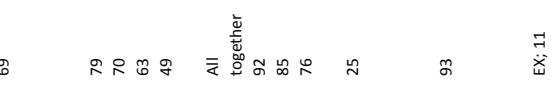
苞

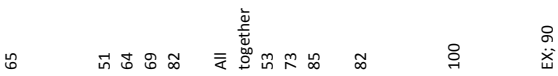

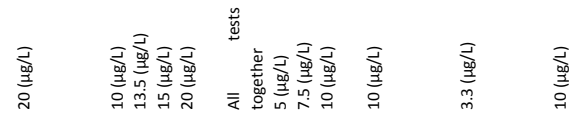

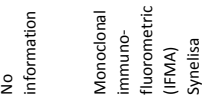

总离离

亳

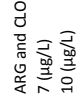

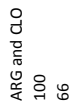

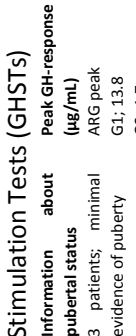

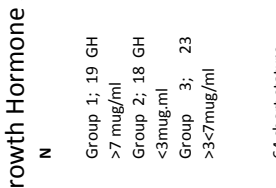

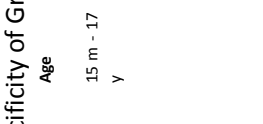

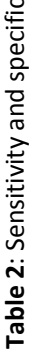

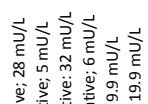

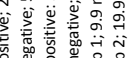

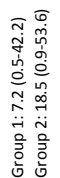

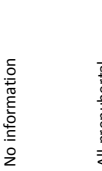

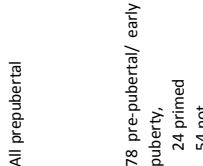

$$
\frac{\sqrt{2}}{\frac{\bar{\alpha}}{2}}
$$

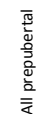

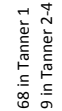

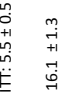

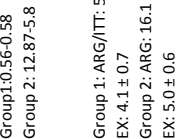

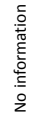

善产

옹 든 옹웍

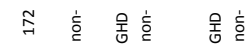

$\because \quad \begin{aligned} & 0 \\ & -1\end{aligned}$

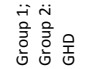

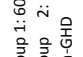

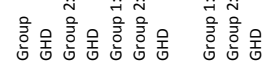

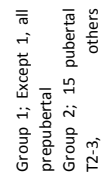

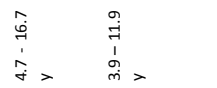

文

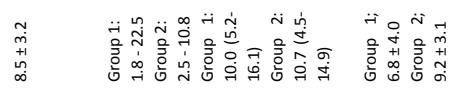

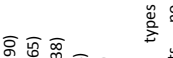

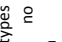

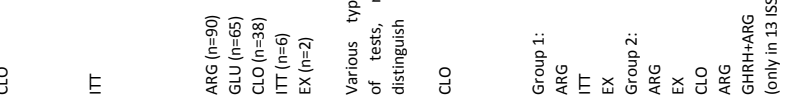

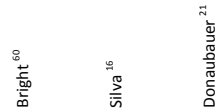



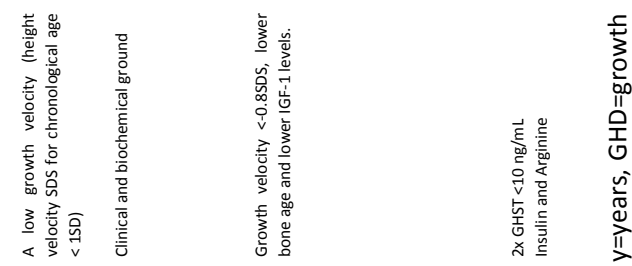

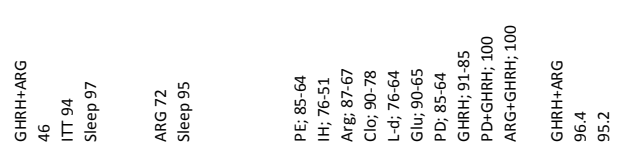

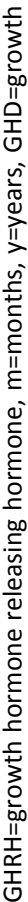

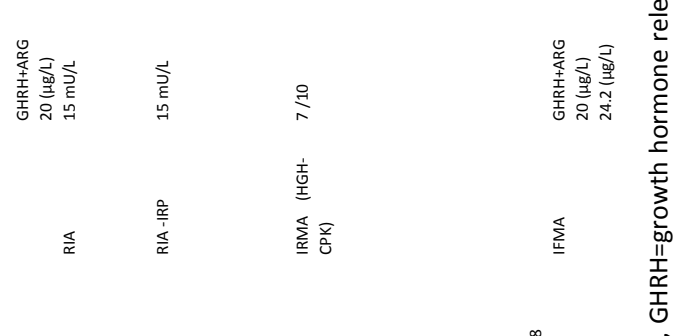

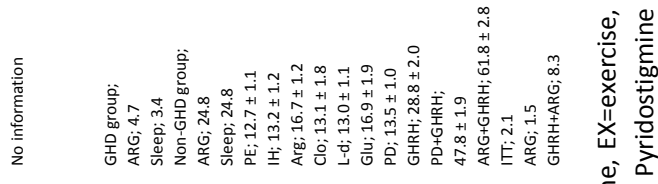

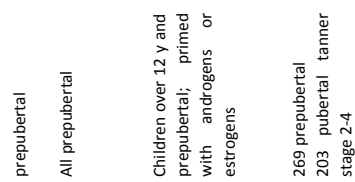

光

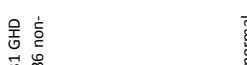

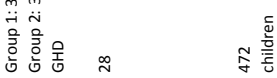

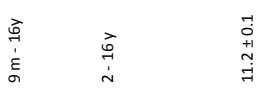
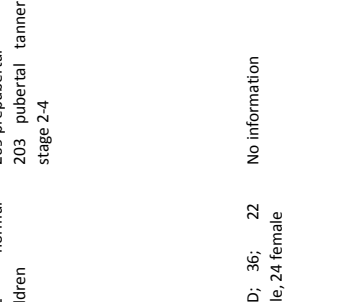

ล⿻ $+\frac{0}{8}$

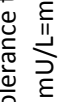

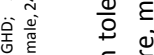

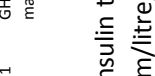

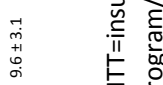

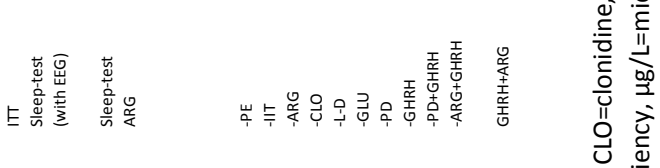

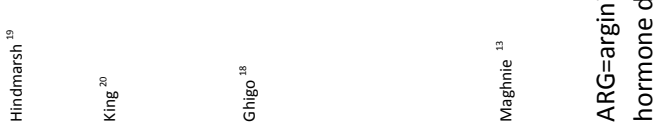


CHAPTER 8
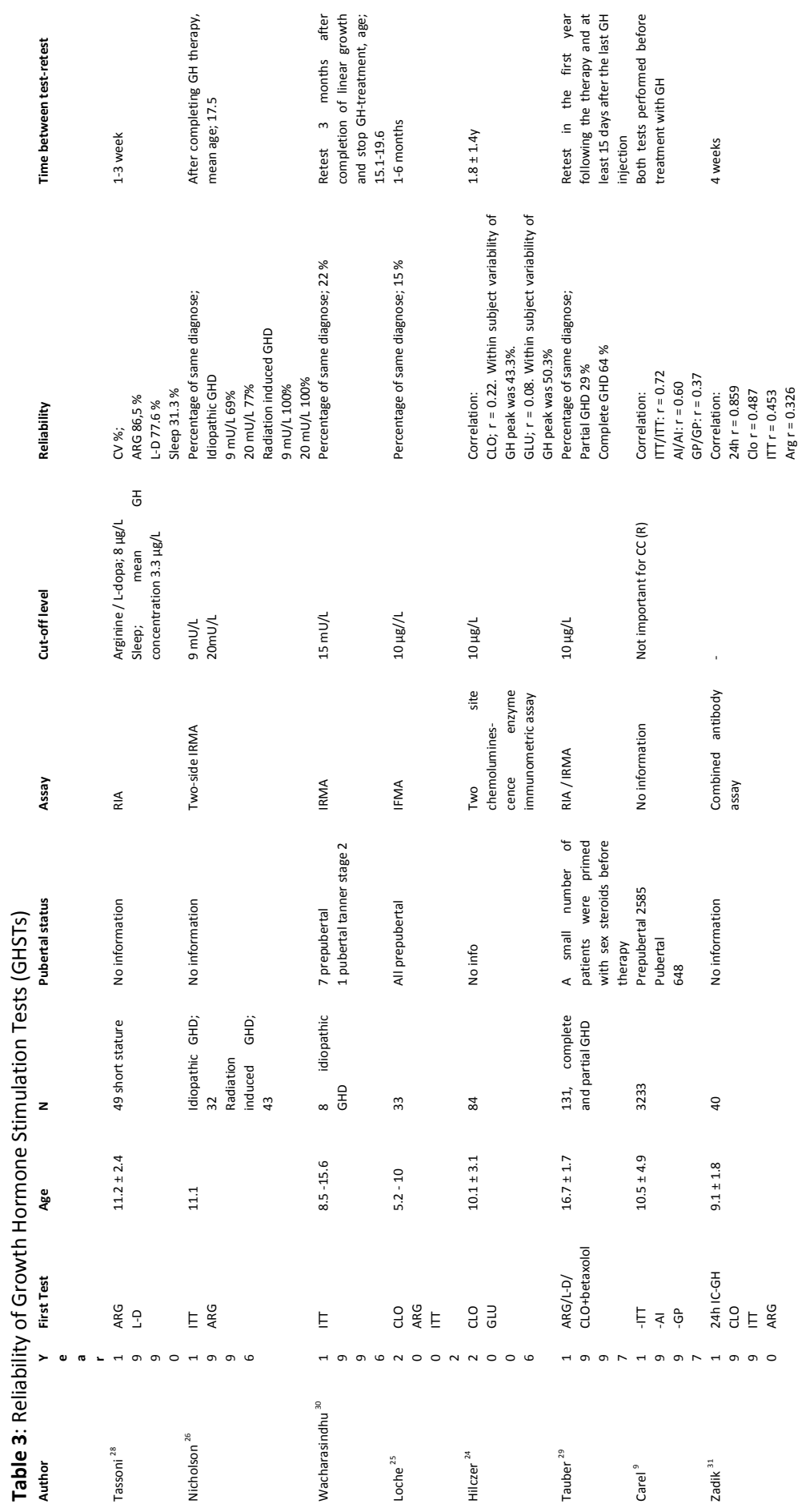

108 


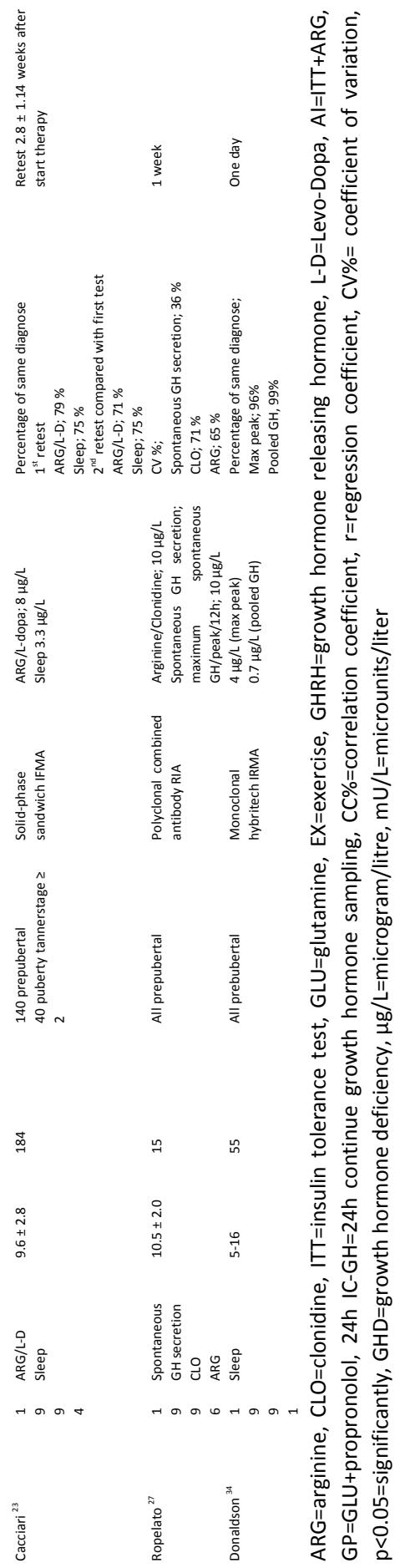


Furthermore all pharmacological agents stimulating GH secretion have side-effects, including nausea, somnolence and hypotension, hypoglycemia, hypokalaemia, cardiac arrithymia ${ }^{33} 36$.

\section{Combined pharmacological tests}

In practice, stimulation tests combining $\mathrm{GH}$ stimulation drugs, i.e. GHRH+ARG, GHRH+pyridostigmine, ITT+ARG or somatostatin+GHRH seem to be more appropriate, compared with the single $\mathrm{GH}$ stimulation tests, because of a reduced variability of the $\mathrm{GH}$ response ${ }^{53}$. The reduced variability in $\mathrm{GH}$ response is caused by a more physiological way of $\mathrm{GH}$ secretion (due to two stimulation agents) and less influence of age and puberty status ${ }^{18}$. Some authors suggest to consider these tests as most reliable tests to assess GH secretory status in children, because these tests are able to assess the maximum secretory capacity of somatotropic cells ${ }^{3,18,54}$. These more physiological tests are however less tested in children, and appropriate cut-off limits need to be applied ${ }^{13}$. Although side-effects of the combined pharmacological tests are not well known, it could be that the same side-effects as the single pharmacological tests will occur.

\section{Physiological tests}

Physiological tests such as the sleep test, exercise test and $24 \mathrm{~h}$ continuously blood sampling are not frequently used, because of practical problems as described in the previous chapter. Although, the sleep test shows in common a higher sensitivity, specificity and reliability, compared with the single pharmacological tests and some authors have suggested physiological assessment of GH secretion may be a more relevant method of identifying children who might benefit from treatment with $\mathrm{GH}$ than the single pharmacological tests ${ }^{8,19,28,34,36}$. The $24 \mathrm{~h}$ continuously blood sampling test showed a high reliability $27,34,49$, although authors may experience the test to distinguish normal from partial GHD difficult, because of the small differences in the $24 \mathrm{~h} \mathrm{GH}$ secretion, especially in puberty $5,10,38,43,52,53$. Furthermore inconvenience to use in practice as described in the previous sectionis a critic on the 24 h continuous blood sampling ${ }^{20,32,33,38}$.

This review shows many problems in the tests used to diagnose GHD, which is most problematic in the diagnosis of partial GHD. Still single pharmacological stimuli of $\mathrm{GH}$ secretion with arginine, insulin, glucagon, $\mathrm{GHRH}$, clonidine and L-dopamine are frequently used and considered in the Consensus of the GHRS to predict successful $\mathrm{GH}$ therapy. 


\section{NEW APPROACH FOR GHSTS}

Besides the two established physiological GH stimulators sleep and exercise, nutrition also influences the $\mathrm{GH}$ secretion. Previous studies have shown that oral ingestion of amino acids (AAs), in particular oral ingestion of arginine (ARG) combined with equal amounts of lysine LYS (ARG:LYS in a ratio of 1:1), stimulates GH secretion potently ${ }^{55}$. We found that ingestion of soy protein (containing relatively high amounts of arginine and lysine in a ratio of ARG:LYS 1:1) increases the GH secretion even to a higher extent than similar amounts of ARG combined with LYS supplemented as single amino acids ${ }^{56}$. The observation that protein, ingested in a physiological dose of 0.6 gram protein per kg bodyweight, simulates the GH secretion to the same physiological level as either exercise or sleep ${ }^{21,23}$, suggests valuable application in the use of protein as stimulation agent in GHSTs.

We did not experience adverse effects during previous studies with such dosages of protein in young women. Ingestion of proteins is cheap, compared with the pharmacological stimuli and it is as easy to ingest as a drink yogurt.

It may be hypothesized that ingestion of dietary protein affects GH secretion through multiple mechanisms, including gastrointestinal signals such as ghrelin ${ }^{57}$, other endocrine signals such as insulin ${ }^{56}$, as well as changes in plasma amino acid concentrations ${ }^{56}$. This makes dietary protein ingestion a more multifactorial and physiological stimulation of $\mathrm{GH}$ secretion than the unifactorial pharmacological GHSTs. Given the higher specificity, sensitivity and reliability of physiological tests in general, or compared with the single pharmacological GHSTs, the above described test may be a promising valuable addition to the existing GHSTs in diagnosing GHD.

However, the described test has not yet been applied in children and has to be further validated with respect to validity and reproducibility. This includes amongst other studies on the predicting value of protein-induced elevation of $\mathrm{GH}$ levels for the efficiency of GH treatment in children suspected of GHD.

\section{SUMMARY/ CONCLUSION}

Since the original observation of low or undetectable serum GH levels in fasting normal children and the extensive overlap in auxological parameters between GHD- and normal- children, the use of physiological or pharmacological stimuli in a provocation test has been the cornerstone for the diagnosis of GHD ${ }^{32,53}$. The current Consensus of the GH Research Society advises among other parameters, to choose 2 pharmacological stimulation tests to predict successful GH therapy ${ }^{7}$. Many factors, however, influence the outcomes of the current used single pharma- 
cological stimulation tests, resulting in more confusing than clarifying the issue ${ }^{11,19}$, 58. Therefore, improving the quality of $\mathrm{GH}$ stimulation tests is important. The quality of the currently used tests can be improved by reducing the tests to maximally 2 or 3 standard tests, depleting a cut-off level valid for each separate test, using the same international protocol and assay for all tests in all laboratories ${ }^{45}$. Moreover, factors such as age, puberty stage, stress, metabolic status must be considered, probably by using matched cut-off levels for different groups. Despite these quality-improvement suggestions, the single stimulation tests remain nonphysiological, which results in different ways of stimulation and the induction of a high inter-individual variability between tests. An alternative, more physiological approach to diagnose GHD in children should be applied or developed to improve measurement- quality in predicting successful therapy. Tests combining two stimulation agents stimulate $\mathrm{GH}$-secretion more physiological than tests using one agent. A sleep test does stimulate $\mathrm{GH}$ secretion in a physiological way, but has some practical difficulties. Therefore, a need for an alternative, convenient, physiological GHST still remains. Oral ingestion of dietary protein is practically convenient and may induce a more physiological stimulation of GH secretion. Hence it may provide a valuable addition to the existing GHSTs in GHD. 


\section{REFERENCES}

1. Vance ML \& Mauras N. Growth hormone therapy in adults and children. N Engl J Med 1999341 12061216.

2. Spiliotis BE, August GP, Hung W, Sonis W, Mendelson W \& Bercu BB. Growth hormone neurosecretory dysfunction. A treatable cause of short stature. Jama 1984251 2223-2230.

3. Sizonenko PC, Clayton PE, Cohen P, Hintz RL, Tanaka T \& Laron Z. Diagnosis and management of growth hormone deficiency in childhood and adolescence. Part 1: diagnosis of growth hormone deficiency. Growth Horm IGF Res 200111 137-165.

4. Shalet SM, Toogood A, Rahim A \& Brennan BM. The diagnosis of growth hormone deficiency in children and adults. Endocr Rev 199819 203-223.

5. Root AW \& Root MJ. Clinical pharmacology of human growth hormone and its secretagogues. Curr Drug Targets Immune Endocr Metabol Disord 20022 27-52.

6. Saggese G, Ranke MB, Saenger P, Rosenfeld RG, Tanaka T, Chaussain JL \& Savage MO. Diagnosis and treatment of growth hormone deficiency in children and adolescents: towards a consensus. Ten years after the Availability of Recombinant Human Growth Hormone Workshop held in Pisa, Italy, 27-28 March 1998. Horm Res 199850 320-340.

7. Consensus guidelines for the diagnosis and treatment of growth hormone (GH) deficiency in childhood and adolescence: summary statement of the GH Research Society. GH Research Society. J Clin Endocrinol Metab 200085 3990-3993.

8. Chemaitilly W, Trivin C, Souberbielle JC \& Brauner R. Assessing short-statured children for growth hormone deficiency. Horm Res 200360 34-42.

9. Carel JC, Tresca JP, Letrait M, Chaussain JL, Lebouc Y, Job JC \& Coste J. Growth hormone testing for the diagnosis of growth hormone deficiency in childhood: a population register-based study. J Clin Endocrinol Metab 199782 2117-2121.

10. Van den Broeck J, Hering P, Van de Lely A \& Hokken-Koelega A. Interpretative difficulties with growth hormone provocative retesting in childhood-onset growth hormone deficiency. Horm Res 199951 1-9.

11. Gandrud LM \& Wilson DM. Is growth hormone stimulation testing in children still appropriate? Growth Horm IGF Res 200414 185-194.

12. Tillmann V, Buckler JM, Kibirige MS, Price DA, Shalet SM, Wales JK, Addison MG, Gill MS, Whatmore AJ \& Clayton PE. Biochemical tests in the diagnosis of childhood growth hormone deficiency. J Clin Endocrinol Metab 199782 531-535.

13. Maghnie M, Cavigioli F, Tinelli C, Autelli M, Arico M, Aimaretti $G$ \& Ghigo E. GHRH plus arginine in the diagnosis of acquired GH deficiency of childhood-onset. J Clin Endocrinol Metab 200287 2740-2744.

14. Comparison of the intravenous insulin and oral clonidine tolerance tests for growth hormone secretion. The Health Services Human Growth Hormone Committee. Arch Dis Child 198156 852-854.

15. Youlton R, Kaplan SL \& Grumbach MM. Growth and growth hormone. IV. Limitations of the growth hormone response to insulin and arginine and of the immunoreactive insulin response to arginine in the assessment of growth hormone deficiency in children. Pediatrics 196943 989-1004.

16. Silva EG, Slhessarenko N, Arnhold IJ, Batista MC, Estefan V, Osorio MG, Marui S \& Mendonca BB. GH values after clonidine stimulation measured by immunofluorometric assay in normal prepubertal children and GH-deficient patients. Horm Res 200359 229-233.

17. Zadik Z, Chalew SA, Gilula Z \& Kowarski AA. Reproducibility of growth hormone testing procedures: a comparison between 24-hour integrated concentration and pharmacological stimulation. $J$ Clin Endocrinol Metab 199071 1127-1130.

18. Ghigo E, Bellone J, Aimaretti G, Bellone S, Loche S, Cappa M, Bartolotta E, Dammacco F \& Camanni F. Reliability of provocative tests to assess growth hormone secretory status. Study in 472 normally growing children. J Clin Endocrinol Metab 199681 3323-3327.

19. Hindmarsh PC, Smith PJ, Taylor BJ, Pringle PJ \& Brook CG. Comparison between a physiological and a pharmacological stimulus of growth hormone secretion: response to stage IV sleep and insulin-induced hypoglycaemia. Lancet 19852 1033-1035.

20. King JM \& Price DA. Sleep-induced growth hormone release--evaluation of a simple test for clinical use. Arch Dis Child 198358 220-222. 
21. Donaubauer J, Kratzsch J, Fritzsch C, Stach B, Kiess W \& Keller E. The treadmill exhausting test is not suitable for screening of growth hormone deficiency! Horm Res 200155 137-140.

22. Cianfarani S, Tondinelli T, Spadoni GL, Scire G, Boemi S \& Boscherini B. Height velocity and IGF-I assessment in the diagnosis of childhood onset GH insufficiency: do we still need a second GH stimulation test? Clin Endocrinol (Oxf) 200257 161-167.

23. Cacciari E, Tassoni P, Cicognani A, Pirazzoli P, Salardi S, Balsamo A, Cassio A, Zucchini S, Colli C, Tassinari D \& et al. Value and limits of pharmacological and physiological tests to diagnose growth hormone (GH) deficiency and predict therapy response: first and second retesting during replacement therapy of patients defined as GH deficient. J Clin Endocrinol Metab 199479 1663-1669.

24. Hilczer M, Smyczynska J \& Lewinski A. Limitations of clinical utility of growth hormone stimulating tests in diagnosing children with short stature. Endocr Regul 200640 69-75.

25. Loche S, Bizzarri C, Maghnie M, Faedda A, Tzialla C, Autelli M, Casini MR \& Cappa M. Results of early reevaluation of growth hormone secretion in short children with apparent growth hormone deficiency. $J$ Pediatr 2002140 445-449.

26. Nicolson A, Toogood AA, Rahim A \& Shalet SM. The prevalence of severe growth hormone deficiency in adults who received growth hormone replacement in childhood [see comment]. Clin Endocrinol (Oxf) 199644 311-316.

27. Ropelato MG, Martinez A, Heinrich JJ \& Bergada C. Reproducibility and comparison of growth hormone secretion tests. J Pediatr Endocrinol Metab 1996 9 41-50.

28. Tassoni P, Cacciari E, Cau M, Colli C, Tosi M, Zucchini S, Cicognani A, Pirazzoli P, Salardi S, Balsamo A \& et al. Variability of growth hormone response to pharmacological and sleep tests performed twice in short children. J Clin Endocrinol Metab 199071 230-234.

29. Tauber M, Moulin P, Pienkowski C, Jouret B \& Rochiccioli P. Growth hormone (GH) retesting and auxological data in $131 \mathrm{GH}$-deficient patients after completion of treatment. J Clin Endocrinol Metab 199782 352-356.

30. Wacharasindhu S, Cotterill AM, Camacho-Hubner C, Besser GM \& Savage MO. Normal growth hormone secretion in growth hormone insufficient children retested after completion of linear growth. Clin Endocrinol (Oxf) 199645 553-556.

31. Zadik Z, Chalew SA, Raiti S \& Kowarski AA. Do short children secrete insufficient growth hormone? Pediatrics 198576 355-360.

32. Rosenfeld RG, Albertsson-Wikland K, Cassorla F, Frasier SD, Hasegawa Y, Hintz RL, Lafranchi S, Lippe B, Loriaux L, Melmed S \& et al. Diagnostic controversy: the diagnosis of childhood growth hormone deficiency revisited. J Clin Endocrinol Metab 199580 1532-1540.

33. Marin G, Domene HM, Barnes KM, Blackwell BJ, Cassorla FG \& Cutler GB, Jr. The effects of estrogen priming and puberty on the growth hormone response to standardized treadmill exercise and arginineinsulin in normal girls and boys. J Clin Endocrinol Metab 199479 537-541.

34. Donaldson DL, Pan F, Hollowell JG, Stevenson JL, Gifford RA \& Moore WV. Reliability of stimulated and spontaneous growth hormone (GH) levels for identifying the child with low GH secretion. J Clin Endocrinol Metab 199172 647-652.

35. Zadik Z, Chalew SA \& Kowarski A. The diagnostic value of integrated growth hormone secretion studies shorter than 24 hours in normal- and short-growing children. Horm Res 199238 250-255.

36. Dattani MT, Pringle PJ, Hindmarsh PC \& Brook CG. What is a normal stimulated growth hormone concentration? J Endocrinol 1992133 447-450.

37. Binder G, Bosk A, Gass M, Ranke MB \& Heidemann PH. Insulin tolerance test causes hypokalaemia and can provoke cardiac arrhythmias. Horm Res 200462 84-87.

38. Rogol AD, Blethen SL, Sy JP \& Veldhuis JD. Do growth hormone (GH) serial sampling, insulin-like growth factor-I (IGF-I) or auxological measurements have an advantage over GH stimulation testing in predicting the linear growth response to GH therapy? Clin Endocrinol (Oxf) 200358 229-237.

39. Ayling R. More guidance on growth hormone deficiency. J Clin Pathol 200457 123-125.

40. Reiter EO \& Martha PM, Jr. Pharmacological testing of growth hormone secretion. Horm Res 199033 121-126; discussion 126-127.

41. Bistritzer T, Chalew SA, Lovchik JC \& Kowarski AA. Growth without growth hormone: the "invisible" GH syndrome. Lancet $19881321-323$. 
42. Hindmarsh PC \& Swift PG. An assessment of growth hormone provocation tests. Arch Dis Child 199572 362-367; discussion 367-368.

43. Rosenfeld RG. Is growth hormone deficiency a viable diagnosis? J Clin Endocrinol Metab 199782 349-351.

44. Stark S \& Willig RP. Growth hormone determination in children using an immunofunctional assay in comparison to conventional assays. Horm Res 200768 171-177.

45. Trainer PJ, Barth J, Sturgeon C \& Wieringaon G. Consensus statement on the standardisation of GH assays. Eur J Endocrinol 2006155 1-2.

46. Levin PA, Chalew SA, Martin L \& Kowarski AA. Comparison of assays for growth hormone using monoclonal or polyclonal antibodies for diagnosis of growth disorders. J Lab Clin Med 1987 109 85-88.

47. Cohen $P$, Rogol AD, Deal CL, Saenger P, Reiter EO, Ross JL, Chernausek SD, Savage MO \& Wit JM. Consensus statement on the diagnosis and treatment of children with idiopathic short stature: a summary of the Growth Hormone Research Society, the Lawson Wilkins Pediatric Endocrine Society, and the European Society for Paediatric Endocrinology Workshop. J Clin Endocrinol Metab 200893 4210-4217.

48. Ranke MB, Orskov H, Bristow AF, Seth J \& Baumann G. Consensus on how to measure growth hormone in serum. Horm Res 199951 Suppl 1 27-29.

49. Zadik Z, Chalew SA \& Kowarski A. Assessment of growth hormone secretion in normal stature children using 24-hour integrated concentration of GH and pharmacological stimulation. $J$ Clin Endocrinol Metab 199071 932-936.

50. Gonc EN, Yordam N, Kandemir N \& Alikasifoglu A. Comparison of stimulated growth hormone levels in primed versus unprimed provocative tests. Effect of various testosterone doses on growth hormone levels. Horm Res 200156 32-37.

51. Cole TJ, Hindmarsh PC \& Dunger DB. Growth hormone (GH) provocation tests and the response to $\mathrm{GH}$ treatment in GH deficiency. Arch Dis Child 200489 1024-1027.

52. Guyda HJ. Four decades of growth hormone therapy for short children: what have we achieved? J Clin Endocrinol Metab 199984 4307-4316.

53. Tzanela M, Guyda H, Van Vliet G \& Tannenbaum GS. Somatostatin pretreatment enhances growth hormone $(\mathrm{GH})$ responsiveness to $\mathrm{GH}$-releasing hormone: a potential new diagnostic approach to $\mathrm{GH}$ deficiency. J Clin Endocrinol Metab 199681 2487-2494.

54. Aimaretti G, Bellone S, Baffoni C, Cornel G, Origlia C, Di Vito L, Rovere S, Arvat E, Camanni F \& Ghigo E. Short procedure of GHRH plus arginine test in clinical practice. Pituitary 20014 129-134.

55. Isidori A, Lo Monaco A \& Cappa M. A study of growth hormone release in man after oral administration of amino acids. Curr Med Res Opin 19817 475-481.

56. van Vught AJ, Nieuwenhuizen AG, Brummer RJ \& Westerterp-Plantenga MS. Effects of oral ingestion of amino acids and proteins on the somatotropic axis. J Clin Endocrinol Metab 200893 584-590.

57. Nakagawa $E$, Nagaya $N$, Okumura $H$, Enomoto $M$, Oya $H$, Ono $F$, Hosoda $H$, Kojima $M$ \& Kangawa $K$. Hyperglycaemia suppresses the secretion of ghrelin, a novel growth-hormone-releasing peptide: responses to the intravenous and oral administration of glucose. Clin Sci (Lond) 2002103 325-328.

58. Gunn IR. Tests for growth hormone deficiency. Lancet 19861 47-48. 



\section{Acute ingestion of gelatin protein increases blunted $\mathrm{GH}$ concentrations in visceral obesity}

ANNEKE J.A.H. VAN VUGHT, ARIE G. NIEUWENHUIZEN, MARGRIET A.B.VELDHORST, ROBERT-JAN M. BRUMMER, MARGRIET S. WESTERTERP-PLANTENGA

SUBMITTED 


\section{ABSTRACT}

Growth hormone $(\mathrm{GH})$, a hormone originating from the anterior pituitary gland, is an important regulator of metabolism and body composition. Low GH secretion is associated with features of the metabolic syndrome, in particular increased visceral body fat and decreased lean body mass. It has been shown that $\mathrm{GH}$ release can be promoted by ingestion of protein, in particular gelatin protein. The question remains; is the $\mathrm{GH}$-promoting effect of gelatin protein is also present in a population with blunted $\mathrm{GH}$ response, such as in visceral obesity.

Eight lean women (age: $23 \pm 3 y, \mathrm{BMI}: 21.6 \pm 2.0 \mathrm{~kg} / \mathrm{m}^{2}$ ) and eight visceral obese women (age: $28 \pm 7 y$, BMI: $33.8 \pm 5.5 \mathrm{~kg} / \mathrm{m}^{2}$ ) were compared with regard to their $\mathrm{GH}$ response after oral ingestion of gelatin protein(gelatin) ( 0.6 gram protein per $\mathrm{kg}$ bodyweight), placebo (water), or injection of growth hormone releasing hormone(GHRH) ( $1 \mu / \mathrm{kg}$ body weight), in a randomized crossover design.

$\mathrm{GH}$ response after placebo, gelatin and GHRH were higher $(p<0.05)$ in lean subjects compared to that in visceral obese subjects $(p<0.05)$. Ingestion of gelatine $(p<0.05)$ increased GH response in both visceral obese $(182.1 \pm 81.6 \mu \mathrm{g} / \mathrm{L} .5 \mathrm{~h}$ vs. $28.4 \pm 29.8$ $\mu \mathrm{g} / \mathrm{L} .5 \mathrm{~h})$ and lean $(631.7 \pm 144.2 \mu \mathrm{g} / \mathrm{L} .5 \mathrm{~h}$ vs. $241.0 \pm 196.8 \mu \mathrm{g} / \mathrm{L} .5 \mathrm{~h})$ subjects. $\mathrm{GH}$ concentration in visceral obese subjects after ingestion of gelatin did not differ from those in lean, placebo-treated subjects $(p=0.45)$.

Thus, the dietary protein gelatin stimulates $\mathrm{GH}$ secretion in visceral obese subjects, to the levels found in placebo-treated lean subjects. Further research is necessary to investigate the relevance of protein as diagnostic tool in hyposomatotropism or in long term as improvement of metabolic abnormalities in hyposomatotropism. 


\section{INTRODUCTION}

Growth hormone $(\mathrm{GH})$, a hormone originating from the anterior pituitary gland, is an important regulator of metabolism and body composition ${ }^{1,2}$. Low GH concentrations are associated with increased body fat, in particular in the visceral regions, and decreased lean body mass ${ }^{3,4}$, known as independent risk factors for cardiovascular disease and type 2 diabetes mellitus, often clustered with insulin resistance, hypertension and dyslipidemia, and defined as the metabolic syndrome ${ }^{5}$. Diurnal $\mathrm{GH}$ concentrations are reduced by $75 \%$ in obese men compared to age-matched normal weight subjects ${ }^{6}$. The proportion of visceral fat of total body fat has been found to be a stronger predictor of diurnal GH release than the proportion total body fat of body mass ${ }^{7}$.

In addition to low $24 \mathrm{~h} \mathrm{GH}$ concentrations, decreased responsiveness to $\mathrm{GH}$ stimulation tests (GHST) has been demonstrated in subjects with obesity and in particular in those with abdominal adiposity ${ }^{8-10}$. GH response to the GHRH-arginine GHST is negatively associated with indices of central abdominal obesity, including waist circumference, trunk fat, and visceral adipose tissue ${ }^{11}$. The state of visceral obesity, with reduced basal and $24 \mathrm{~h} \mathrm{GH}$ release as well as low responsiveness to $\mathrm{GH}$ stimulation tests is defined as hyposomatotropism ${ }^{12,13}$ and has several similarities with adult $\mathrm{GH}$ deficiency, including increased abdominal fat depots, insulin resistance, high serum levels of triglycerides (TG) and low serum levels of high-density lipoprotein (HDL)-cholesterol ${ }^{7,14,15}$. GH administration has shown to reverse the metabolic abnormalities in adult hyposomatotropism and thereby decrease visceral fat mass, increase muscle mass and improve insulin sensitivity ${ }^{16,17}$.

It has been shown that $\mathrm{GH}$ secretion can be promoted by intravenous or oral administration of various amino acids (AAs), either alone or in combination ${ }^{18,19}$. Especially ingestion of the AA arginine (ARG) was found to be a strong stimulator of $\mathrm{GH}$ secretion ${ }^{20,21}$. Recently, we reported that ingestion of various dietary proteins, including soy, milk, alpha lactalbumin and gelatin, stimulates the $\mathrm{GH}$ secretion in lean subjects, with the ARG-rich gelatin being the most potent stimulator (a 4 fold increase compared with baseline) ${ }^{22}$. It remains, however, to be established if this $\mathrm{GH}$-promoting effect of gelatin protein is also present in a population with blunted $\mathrm{GH}$ secretion, such as in visceral obesity. This would offer a non-pharmacologic option to counteract the negative consequences of hyposomatotropism. To examine this question, lean and obese subjects were compared with regard to their somatotropic response to a growth hormone stimulation test (i.e. growth hormone releasing hormone), oral ingestion of gelatin protein and a placebo drink. 


\section{METHODS}

\section{Subjects}

Subjects were recruited via local advertisements. Sixteen females participated. Eight had a BMI below $23 \mathrm{~kg} / \mathrm{m}^{2}$ and a waist circumference below $80 \mathrm{~cm}$ and eight a BMI above $30 \mathrm{~kg} / \mathrm{m}^{2}$ and a waist circumference above $90 \mathrm{~cm}$. Each subject was in good health, non smoking, and used oral contraceptives. They were free of any other medication and spent less than three hours a week on sport activities. All tests were performed in the early follicular phase of the menstrual cycle, in order to eliminate confounding by changing serum estrogens concentrations. The Medical Ethics Committee of Maastricht University approved the study protocol and all subjects gave their written informed consent before participating in the study.

\section{Experimental design}

A randomized crossover study design was applied. Subjects reported to the laboratory at three different days in the morning. A standard GHRH stimulation test was performed once and subjects received a test drink (gelatin or placebo) twice. They were instructed to fast from $10 \mathrm{pm}$ the night prior to the test day. A permanent canula was placed into a dorsal arm vein of the contralateral arm.

During the standard GHRH stimulation test, 1 microgram GHRH (FERRING B.V., Hoofddorp, The Netherlands) per kg bodyweight was administered, 40 min after placement of the canula. Just before and at 15, 30, 45, 60, 75 and 90 min after the injection of $\mathrm{GHRH}$, blood was sampled to analyse $\mathrm{GH}$, insulin and glucose concentrations

During the other 2 test days, blood sampling started 40 min after placement of the canula. Immediately after obtaining the first blood sample, subjects received a test drink, containing placebo or gelatin. The gelatin test drink contained 0.6 gram gelatin protein (Solugel LMC/3, 100PB Gelatins GmbH, Nienburg/Weser, Germany) per $\mathrm{kg}$ bodyweight dissolved in $400 \mathrm{ml}$ water with $20 \mathrm{ml}$ sugarfree syrup (Diaran, Cereal). The placebo test drink contained $400 \mathrm{ml}$ water with $20 \mathrm{ml}$ sugarfree syrup. The syrup was added for the taste and contained no protein and fat and a negligible amount of carbohydrates. Blood was sampled every $20 \mathrm{~min}$ for the next $5 \mathrm{~h}$ to determine $\mathrm{GH}$ concentrations. Insulin and glucose concentrations were determined just before ingestion of the test drink and 40, 60, 180 and $300 \mathrm{~min}$, after ingestion of the test drink. During blood sampling, subjects remained awake and were allowed to drink water ad libitum. 


\section{Anthropometric assessment}

Measurement of waist circumference was performed in triplicate at the iliac crest in a standardized fashion with the subject in an upright position. Measurement of hip circumference was performed at the maximum circumference of the buttocks with the subject in an upright position. Body fat and fat free mass were determined by DXA (Discovery A, Hologic (Bedford, MA, USA)) testing. Measurements of regional adiposity using DEXA were standardized. The technique has a precision error of less than $1 \%$ for fat mass and lean body mass. BMI was calculated by total body weight/height ${ }^{2}$, fat mass index (FMI) was calculated by absolute fat mass/ height ${ }^{2}$.

\section{Blood analysis}

Venous blood was collected in clot tubes, containing 'Silica Clot Activator' (Becton Dickinson Vacutainer system; Becton Dickinson, Franklin Lakes, NJ, USA), and in heparinised tubes Becton Dickinson Vacutainer system; Becton Dickinson, Franklin Lakes, NJ, USA). Blood in these tubes was allowed to clot for 30 minutes and was centrifuged at $3000 \mathrm{rpm}, 4^{\circ} \mathrm{C}$ for $10 \mathrm{~min}$ to obtain serum. Serum was collected for determination of $\mathrm{GH}$ concentrations. Blood in heparinised tubes was kept on ice to minimize enzymatic reactions and centrifuged at $3000 \mathrm{rpm}$ at $4^{\circ} \mathrm{C}$ for $10 \mathrm{~min}$ to obtain plasma. Glucose and insulin analyses were performed in plasma. Each aliquot was frozen immediately in liquid nitrogen and stored at $-80^{\circ} \mathrm{C}$. All samples from the same subjects were run in the same assay.

The GH-concentrations were measured using an ultrasensitive $\mathrm{GH}$ chemiluminescence immunoassay (Beckman Coulter, Harbor Blvd. Fullerton, U.S.A.). The intraand inter-assay coefficients of variation were $1.4-2.1$ and $6.8-8.6 \%$ respectively, at GH concentrations of 3.7-14.2 and 3.1-7.3 $\mu \mathrm{g} / \mathrm{l}$, respectively. Insulin concentrations were measured by an electrochemiluminescence immunoassay (ELICA) (Roche Diagnostica, Hoffman-La Roche, Basel, Switzerland). Glucose concentrations were measured using enzymatic assay (G6-PDH) (Roche Diagnostica, Hoffman-La Roche, Basel, Switzerland). 
Table 1: Characteristics of study subjects

\begin{tabular}{lccc} 
& Lean women & Visceral obese women & $p$ \\
\hline $\mathrm{n}$ & 8 & 8 & 0.12 \\
Age (yr) & $23 \pm 3$ & $28 \pm 7$ & 0.26 \\
Anthropometrics & & & $<0.001$ \\
$\quad$ Height (cm) & $169.8 \pm 7.8$ & $166.3 \pm 3.3$ & $<0.001$ \\
Body weight (kg) & $62.3 \pm 7.7$ & $93.3 \pm 15.7$ & $<0.001$ \\
BMI (kg/m2) & $21.6 \pm 2.0$ & $33.8 \pm 5.5$ & $<0.001$ \\
Waist circumference (cm) & $71.7 \pm 3.8$ & $100.0 \pm 10.3$ & $<0.001$ \\
Hip circumference (cm) & $93.6 \pm 4.8$ & $119.5 \pm 17.2$ & $<0.001$ \\
Waist:Hip (WHR) & $0.7 \pm 0.0$ & $0.8 \pm 0.0$ & $<0.001$ \\
DEXA & & & $<0.001$ \\
Total fat (kg) & $15.5 \pm 4.9$ & $35.6 \pm 9.5$ & $<0.001$ \\
Trunk fat (kg) & $6.1 \pm 2.6$ & $17.9 \pm 5.8$ & $<0.001$ \\
\% Fat mass & $25.4 \pm 6.2$ & $37.6 \pm 6.6$ & $<0.05$ \\
\% Trunk fat from total fat mass & $38.5 \pm 6.2$ & $49.7 \pm 5.1$ & $<0.05$ \\
FMI & $5.3 \pm 1.6$ & $12.9 \pm 3.3$ & $18.2 \pm 3.0$ \\
Insulin (basal) (mU/L) & $8.1 \pm 1.9$ & $5.8 \pm 0.3$ & \\
Glucose (basal) (mmol/L) & $4.9 \pm 0.2$ & & \\
\hline
\end{tabular}

$\mathrm{FMI}=$ fat mass index; (absolute fat mass $/$ height $^{2}$ )

\section{Statistics}

All data are expressed as mean +/- standard deviation (SD). Growth hormone, insulin and glucose responses were calculated as incremental area under the curve (i.e. area under the curve - baseline $(\triangle I A U C)$ ) and peak values (i.e. peak - baseline $(\triangle$ peak)). The nonparametric Mann-Whitney $U$ test was used to test for differences between lean subjects with visceral obese subjects. Repeated measures analysis of variance (ANOVA) was performed to compare between test conditions within one group. Associations between $\mathrm{GH}$ concentrations after injection of $\mathrm{GHRH}$ and ingestion of gelatin were calculated using the Peasons correlation. Coefficient of variation (CV\%) in $\mathrm{GH}$ response is the ratio of the SD to the mean. A p-value $<0.05$ was regarded as statistically significant. All statistical analyses were performed using SPSS for WINDOWS, version 15.0; SPSS, Chicago, IL.

\section{RESULTS}

As shown in Table 1, visceral obese and lean subjects differed with respect to body weight, BMI, waist circumference, hip circumference, waist to hip ratio (WHR), total fat mass, trunk fat mass, $\%$ fat mass, \% trunk fat mass from total fat mass and fat mass index (FMI) $(p<0.001)$.

$\mathrm{GH}$ responses expressed as incremental area under the curve (IAUC) as well as $\triangle$ peak-values after i.v. injection of GHRH, were significantly higher in lean subjects compared to those with visceral obesity $(p<0.05)$ confirming a blunted $\mathrm{GH}$ response to GHRH stimulation in our subjects with visceral obesity (Figure 1). 

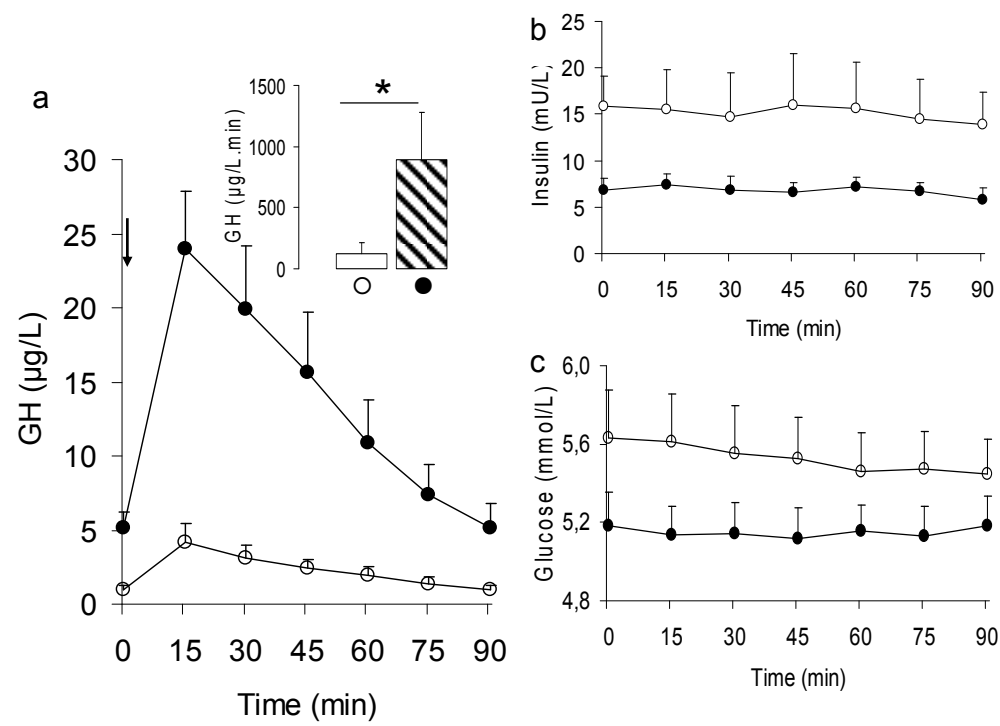

Figure 1: Growth hormone concentrations (a), insulin concentrations (b) and glucose concentrations (c) after i.v. injection of GHRH in lean subjects $(\bullet)(n=8)$ and visceral obese subjects $(0)(n=8)$. Data are presented as mean $( \pm S D)$ in lines. ${ }^{*}=p<0.05$

In both visceral obese and well as in lean subjects, growth hormone responses (IAUC and $\triangle$ peak) were significantly higher after ingestion of gelatin compared to placebo $(p<0.05)$ (Figure 2$)$. Basal $\mathrm{GH}$-concentrations were significantly lower in visceral obese subjects, compared with lean subjects $(p<0.05)$. GH-responses (IAUC and $\Delta$ peak) after ingestion of gelatin protein or placebo, were significantly higher in lean subjects compared with visceral obese subjects $(p<0.05)$. GH responses as determined by IAUC as well as $\triangle$ peak-values after the placebo ingestion in lean subjects did not differ significantly from those after gelatin ingestion in visceral obese subjects ( $p=0.45)$ (Figure 2$)$. In the whole group, individual AUC and peak values of $\mathrm{GH}$ concentrations after $\mathrm{GHRH}$ injection correlated significantly with AUC and peak values of $\mathrm{GH}$ concentrations after gelatin ingestion (AUC; $r=0.71, p<0.01$, Peak; $r=0.68, p<0.01)$. The coefficient of variation $(C V \%)$ in $\mathrm{GH}$ response in the lean subjects after GHRH was $39 \%$ and after gelatin protein $22 \%$. In the obese subjects, the $\mathrm{CV} \%$ in $\mathrm{GH}$ response after $\mathrm{GHRH}$ was $67 \%$ and after gelatin protein $43 \%$.

Insulin responses expressed as IAUC and $\triangle$ peak values were higher after ingestion of gelatin protein compared with placebo $(p<0.05)$. Basal insulin-concentrations (obese; $18.2 \pm 3.0 \mathrm{mU} / \mathrm{L}$ vs. lean; $8.1 \pm 1.9 \mathrm{mU} / \mathrm{L}$ ) and basal glucose concentrations (obese; $5.8 \pm 0.3 \mathrm{mmol} / \mathrm{L}$ vs. lean; $4.9 \pm 0.2 \mathrm{mmol} / \mathrm{L}$ ) were significantly higher in visceral obese than in lean subjects $(p<0.05)$ suggesting decreased insulin sensitivity in the visceral obese subjects. 


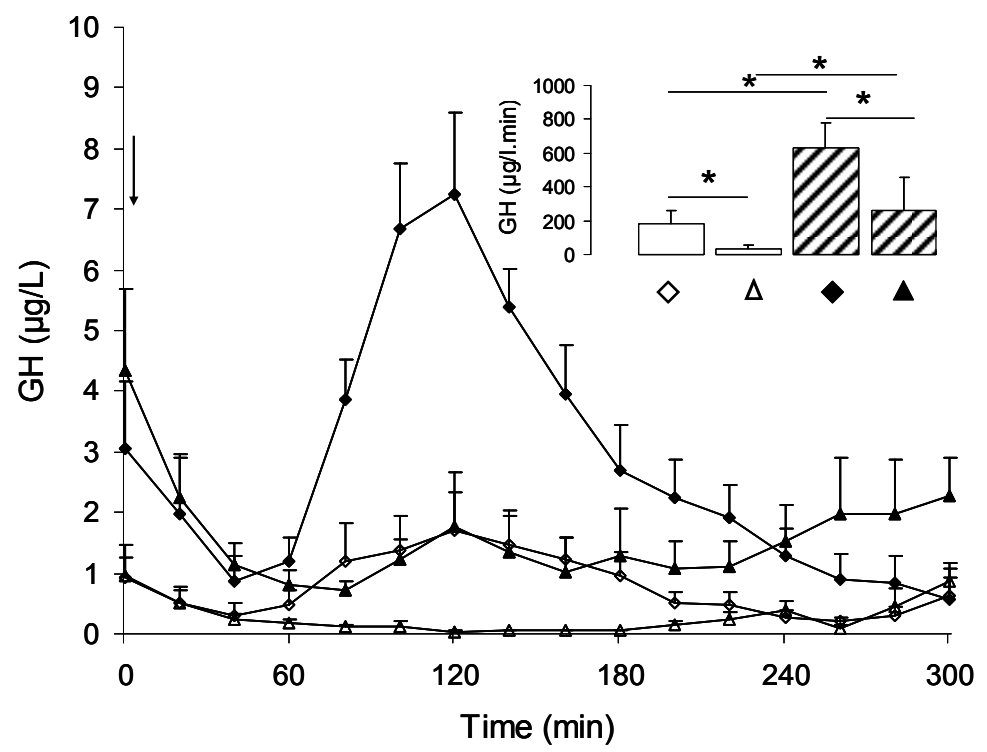

Figure 2: $\mathrm{GH}$ concentrations after ingestion of a test drink containing gelatin protein $(\Delta=\mathrm{lean}$, $\diamond=$ visceral obese) or placebo ( $\boldsymbol{\Delta}=$ lean, $\Delta=$ visceral obese). Data are presented as mean ( \pm SD) in lines and bars (AUC). $\downarrow=$ ingestion of test drink. ${ }^{*}=p<0.05$

\section{DISCUSSION}

This study shows that oral intake of a dietary protein (gelatin) stimulates the $\mathrm{GH}$ secretion in a visceral obese population, albeit to a lesser extent than in lean subjects. This resembles the blunted GH responses to $\mathrm{GH}$ stimulation tests (GHST) in visceral obese subjects as shown by others ${ }^{10,11}$, and confirmed in this study. The GH concentrations after ingestion of gelatin protein in visceral obese subjects stimulates the $\mathrm{GH}$ release to the same levels found in placebo treated lean subjects.

We previously showed that protein ingestion stimulates $\mathrm{GH}$ secretion in healthy lean women, with gelatin protein as the strongest GH stimulator among different types of protein ${ }^{22}$. The present study shows that this GH promoting activity of dietary protein prevailed in the visceral obese subjects. The reduction in $\mathrm{GH}$ response to ingestion of gelatin in visceral obese subjects compared with the lean subjects is associated with reduced $\mathrm{GH}$ responses to GHRH stimulation. These data may imply an overall hypothalamic and pituitary mediated decreased GH secretory response and capacity in visceral obese subjects. Since GHRH is widely used as stimulating agent for a GH stimulation test (GHST) in the diagnosis of GHD, one may speculate that oral ingestion of a dietary protein such as gelatin is a potential alternative physiologic GH stimulator that can be used to diagnose GHD. The CV\% 
in $\mathrm{GH}$ response after $\mathrm{GHRH}$ is higher then after gelatin protein. Less variation may indicate that the test outcome distinguishes better between groups (hyposomatotropic and non-hyposomatotropic). In view of the complications and limitations of the current GHST's ${ }^{23}$, further studies on the validity and reliability of dietary protein ingestion in the diagnosis of GHD (i.e. in children suspected of GHD) seem appropriate.

Gelatin ingestion in visceral obese subjects increased circulating $\mathrm{GH}$ concentrations to the level of placebo-treated lean subjects. As shown in several studies, GH therapy, i.e., repeated i.v. injection of $\mathrm{GH}$, can reverse the metabolic abnormalities shown in adults with hyposomatotropism ${ }^{3,13,16,17,24-27}$. A recent meta-analysis of Mekala et al. 2009, showed beneficial effects of GH therapy on body composition, including a decrease in body fat, increase in lean body mass, improvement in body fat distribution, as well as a decrease in WHR and visceral adiposity. GH therapy may also favourably affect lipid profile, leading to a decrease in total and LDLcholesterol ${ }^{27}$. It seems reasonable to suggest that stimulation of endogenous $\mathrm{GH}$ secretion by other $\mathrm{GH}$ secretagogues may restore the reduced somatotropic activity in visceral obese subjects, leading to improved values of parameters of cardiometabolic risk. A study in HIV patients with reduced GH concentrations investigated long term effect of GHRH administration ${ }^{27,} 28$ and found normalised IGF-1 concentrations after administration of GHRH for 26 weeks, simultaneously reduced visceral adiposity and improvements in dyslipidemia were found ${ }^{28}$. Although the current study shows that ingestion of dietary protein acutely restores decreased plasma GH concentrations in visceral obese subjects, more long-term studies are required to establish whether dietary protein ingestion can also be used to chronically improve somatotropic activity in visceral obesity and hyposomatotropism in general, and whether this strategy is effective in (partially) reversing the associated metabolic abnormalities.

Glucose concentrations, especially at baseline, were higher in visceral obese subjects compared with lean subjects $(5.8 \pm 0.3 \mathrm{mmol} / \mathrm{L}$ vs. $4.9 \pm 0.2 \mathrm{mmol} / \mathrm{L}$ respectively), however it is unlikely that this affects the results, since none of the subjects were hyperglycaemic and hyperglycaemia is known to reduce $\mathrm{GH}$ secretion. The tendency to higher delta insulin peak values in visceral obese subjects compared with lean subjects may be partly explain the reduced $\mathrm{GH}$ concentrations, since insulin is known to stimulate IGF-1, which is known to inhibit GH secretion via a negative feedback loop ${ }^{29}$.

In conclusion, ingestion of dietary protein (gelatin) stimulates $\mathrm{GH}$ secretion in visceral obesity, to the levels found in placebo-treated lean subjects. Further research is necessary to investigate whether dietary protein can be used as an appropriate and physiological stimulator, in the diagnostic work-up of hyposomatotropism and whether prolonged use of dietary proteins with GH secretory capacity is able to improve metabolic abnormalities in visceral obesity in the long term. 


\section{REFERENCES}

1. Veldhuis JD, Roemmich JN, Richmond EJ, Rogol AD, Lovejoy JC, Sheffield-Moore M, Mauras N \& Bowers CY. Endocrine control of body composition in infancy, childhood, and puberty. Endocr Rev 200526114 146.

2. Moller N \& Jorgensen JO. Effects of Growth Hormone on Glucose, Lipid and Protein Metabolism in Human Subjects. Endocr Rev 2009.

3. Carrel AL \& Allen DB. Effects of growth hormone on adipose tissue. J Pediatr Endocrinol Metab 200013 Suppl 2 1003-1009.

4. Gerver WJ, De Bruin R, Delemarre v d Waal HA, Aldewereld B, Theunissen P \& Westerterp KR. Effects of discontinuation of growth hormone treatment on body composition and metabolism. Horm Res 200053 215-220.

5. Wajchenberg BL. Subcutaneous and visceral adipose tissue: their relation to the metabolic syndrome. Endocr Rev 200021 697-738.

6. Veldhuis JD, Iranmanesh A, Ho KK, Waters MJ, Johnson ML \& Lizarralde G. Dual defects in pulsatile growth hormone secretion and clearance subserve the hyposomatotropism of obesity in man. J Clin Endocrinol Metab 199172 51-59.

7. Clasey JL, Weltman A, Patrie J, Weltman JY, Pezzoli S, Bouchard C, Thorner MO \& Hartman ML. Abdominal visceral fat and fasting insulin are important predictors of 24-hour GH release independent of age, gender, and other physiological factors. J Clin Endocrinol Metab 200186 3845-3852.

8. Cordido F, Dieguez C \& Casanueva FF. Effect of central cholinergic neurotransmission enhancement by pyridostigmine on the growth hormone secretion elicited by clonidine, arginine, or hypoglycemia in normal and obese subjects. J Clin Endocrinol Metab 199070 1361-1370.

9. Hartman ML, Crowe BJ, Biller BM, Ho KK, Clemmons DR \& Chipman JJ. Which patients do not require a GH stimulation test for the diagnosis of adult GH deficiency? J Clin Endocrinol Metab 200287 477-485.

10. Vizner B, Reiner Z \& Sekso M. Effect of I-dopa on growth hormone, glucose, insulin, and cortisol response in obese subjects. Exp Clin Endocrinol 198381 41-48.

11. Makimura H, Stanley T, Mun D, You SM \& Grinspoon S. The effects of central adiposity on growth hormone $(\mathrm{GH})$ response to $\mathrm{GH}$-releasing hormone-arginine stimulation testing in men. $J$ Clin Endocrinol Metab 200893 4254-4260.

12. Buijs MM, Burggraaf J, Langendonk JG, Schoemaker RC, Frolich M, Arndt JW, Cohen AF, Romijn JA, Ackermans MT, Sauerwein HP, Meinders AE \& Pijl H. Hyposomatotropism blunts lipolysis in abdominally obese women. J Clin Endocrinol Metab 200287 3851-3858.

13. de Boer H, Blok GJ \& Van der Veen EA. Clinical aspects of growth hormone deficiency in adults. Endocr Rev 199516 63-86.

14. Rosen $T$, Johannsson G, Johansson JO \& Bengtsson BA. Consequences of growth hormone deficiency in adults and the benefits and risks of recombinant human growth hormone treatment. A review paper. Horm Res 199543 93-99.

15. Vahl N, Jorgensen JO, Skjaerbaek C, Veldhuis JD, Orskov H \& Christiansen JS. Abdominal adiposity rather than age and sex predicts mass and regularity of GH secretion in healthy adults. Am J Physiol 1997272 E1108-1116.

16. Franco C, Brandberg J, Lonn L, Andersson B, Bengtsson BA \& Johannsson G. Growth hormone treatment reduces abdominal visceral fat in postmenopausal women with abdominal obesity: a 12-month placebocontrolled trial. J Clin Endocrinol Metab 200590 1466-1474.

17. Johannsson G, Marin P, Lonn L, Ottosson M, Stenlof K, Bjorntorp P, Sjostrom L \& Bengtsson BA. Growth hormone treatment of abdominally obese men reduces abdominal fat mass, improves glucose and lipoprotein metabolism, and reduces diastolic blood pressure. J Clin Endocrinol Metab 199782 727-734.

18. Chromiak JA \& Antonio J. Use of amino acids as growth hormone-releasing agents by athletes. Nutrition 200218 657-661.

19. Knopf RF, Conn JW, Fajans SS, Floyd JC, Guntsche EM \& Rull JA. Plasma Growth Hormone Response To Intravenous Administration Of Amino Acids. J Clin Endocrinol Metab 196525 1140-1144.

20. Isidori A, Lo Monaco A \& Cappa M. A study of growth hormone release in man after oral administration of amino acids. Curr Med Res Opin 19817 475-481. 
21. Collier SR, Casey DP \& Kanaley JA. Growth hormone responses to varying doses of oral arginine. Growth Horm IGF Res 200515 136-139.

22. van Vught AJAH, Nieuwenhuizen AG, Gerver WJ, Veldhorst MAB, Brummer RJM \& Westerterp-Plantenga MS. Somatotropic effects of soy-, gelatin-, alpha-lactalbumin- and milk protein. (In revision) 2009.

23. Van vught JAH, Nieuwenhuizen AG, Gerver WJ, Veldhorst MAB, Brummer RJM \& Westerterp-Plantenga MS. Pharmacological and physiological growth hormone stimulation tests to predict successful GH therapy in children JPEM (in press) 2008.

24. Abdul Shakoor SK \& Shalet SM. Effects of GH replacement on metabolism and physical performance in GH deficient adults. J Endocrinol Invest 200326 911-918.

25. Carrel AL \& Allen DB. Effects of growth hormone on body composition and bone metabolism. Endocrine 200012 163-172.

26. Jorgensen JO, Pedersen SA, Thuesen L, Jorgensen J, Ingemann-Hansen T, Skakkebaek NE \& Christiansen JS. Beneficial effects of growth hormone treatment in GH-deficient adults. Lancet 1989 1221-1225.

27. Mekala KC \& Tritos NA. Effects of recombinant human growth hormone therapy in obesity in adults: a meta analysis. J Clin Endocrinol Metab 200994 130-137.

28. Falutz J, Allas S, Blot K, Potvin D, Kotler D, Somero M, Berger D, Brown S, Richmond G, Fessel J, Turner R \& Grinspoon S. Metabolic effects of a growth hormone-releasing factor in patients with HIV. N Engl J Med 2007357 2359-2370.

29. Franco C, Bengtsson BA \& Johannsson G. The GH/IGF-1 Axis in Obesity: Physiological and Pathological Aspects. Metab Syndr Relat Disord 20064 51-56. 



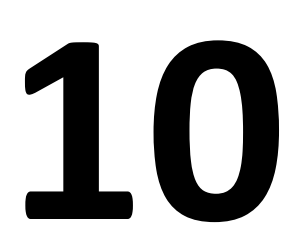

General discussion 
The somatotropic axis plays a central role in the regulation of linear growth and body composition. A dysfunction of the somatotropic axis results in a reduced linear growth in children, a reduced muscle and bone mass and increased fat mass in children and adults. The effects of dietary protein on the regulation of the somatotropic axis in short term, long term and in pathophysiological conditions are discussed in this chapter.

\section{SHORT TERM NEUROENDOCRINE REGULATION OF THE SOMATOTROPIC AXIS BY PROTEIN}

\section{Amino acids}

The release of the somatotropic axis is stimulated by i.v. injection or oral ingestion of several amino acids (AAs). Arginine in combination with lysine, have been shown to stimulate the $\mathrm{GH}$ release by 8 fold ${ }^{1,2}$. In our studies, we found that ingestion of a mixture of 20 AAs reflecting a dietary protein (i.e. soy protein) is even more potent in stimulating $\mathrm{GH}$ release than ingestion of a mixture of arginine and lysine ${ }^{3}$. In both conditions the same amounts of arginine and lysine were present, however serum arginine concentrations were higher after ingestion of the complex AA mixture compared with the mixture of arginine and lysine. This indicates that in addition to arginine and lysine, other AAs are indirectly involved in the observed stimulation of $\mathrm{GH}$ release, possibly via conversion into arginine. Several nonessential AAs are known to convert into arginine, for instance histidine and proline can convert from glutamine/glutamate to ornitine, citruline and finally into arginine

${ }^{4}$. Furthermore, other AAs than arginine and lysine are also known to stimulate the $\mathrm{GH}$ release directly ${ }^{5}$.

Although the AA composition of the test drinks influences the somatotropic response, the chain length of protein was not of pivotal value for the $\mathrm{GH}$ response, since $\mathrm{GH}$ responses were similar after ingestion of a mixture of single AAs, a hydrolysed protein and a complete protein. Despite no differences between $\mathrm{GH}$ secretion over time after ingestion of an AA mixture, hydrolyzed protein and complete protein, total AA absorption was faster when single AAs were ingested ${ }^{3}$. However, the time to the peak serum concentration of arginine and lysine was not different between the conditions, suggesting that serum concentrations of certain AAs as arginine and lysine are more important than the total serum AA concentrations. 


\section{Protein sources}

The above mentioned studies suggest that the GH secretory response to dietary protein is dependent on ingestion of the amount and type of AAs. Soy was hypothesized being a relatively strong $\mathrm{GH}$ stimulator among the proteins because of its relatively high content of arginine and lysine. However, this hypothesis was not confirmed by a study in which we compared ingestion of 4 different protein types and studied the effect of these different AA compositions on the somatotropic release. Gelatin protein, which contains the highest amounts of arginine, is a stronger GH stimulator than soy protein, alpha lactalbumin protein and milk protein ${ }^{6}$. We found that serum arginine concentrations were higher after gelatin protein ingestion than after ingestion of the other protein sources. We also found that serum arginine concentrations were higher after soy protein ingestion than after alpha lactalbumin protein or milk protein ingestion, although ingestion of soy protein, alpha lactalbumin protein or milk protein evoked similar $\mathrm{GH}$ concentrations. This indicates that a high concentration of arginine stimulates the release of $\mathrm{GH}$, although in addition to arginine other AAs are involved in $\mathrm{GH}$ release such as for instance methionine (high in milk protein) and lysine (high in alpha lactalbumin protein) ${ }^{6}$.

\section{Presence of macronutrients}

Serum concentrations of specific AAs influence the $\mathrm{GH}$ release, furthermore the presence of free fatty acids (FFA) and glucose in blood affect the somatotropic release. Elevated plasma FFA concentrations ${ }^{7}$, as well as elevated plasma glucose concentrations are known to suppress the release of $\mathrm{GH}^{8}$. Since a typical meal consumed by humans consists of a mixture of 3 macronutrients and not of protein alone, the interaction of ingested carbohydrates and fat with the $\mathrm{GH}$ promoting effect of protein is studied. We found that the somatotropic effect of protein was eliminated when soy protein was ingested combined with carbohydrate and fat, however remained unchanged over 5 hours when protein was combined with either carbohydrate or fat ${ }^{9,10}$. This indicates that in addition to protein, the combination of carbohydrate and fat plays a modulating role in the postprandial secretion of $\mathrm{GH}$ after ingestion of a high protein meal.

Ingestion of carbohydrates alone does not affect the 5 hour $\mathrm{GH}$ response after protein ingestion, however it changes the secretory pattern of protein induced $\mathrm{GH}$ release; a second peak occurs when protein is combined with carbohydrates, approximately 4 hours after ingestion. The addition of carbohydrates to protein resulted in changes in protein metabolism, since the AA concentrations stay higher for a longer time when protein was co-ingested with carbohydrates than after 
protein ingestion alone, which may explain the second $\mathrm{GH}$ peak. A possible explanation is that gluconeogenesis is higher when only protein is ingested compared with ingestion of protein plus carbohydrates, resulting in a faster decrease of serum AA concentrations after the combined ingestion of protein alone than after ingestion of protein plus carbohydrate ${ }^{11}$.

We reported that fat delays the protein induced GH peak, however it does not affect the $\mathrm{GH}$ response. The delayed $\mathrm{GH}$ peak is neither explained by the serum $\mathrm{AA}$ concentrations, nor by the peak insulin concentrations. Possibly a direct effect of fat intake on somatostatin secretion could cause delay in the $\mathrm{GH}$ response ${ }^{12,13}$. It remains unclear why the quantity of $\mathrm{GH}$ release after protein ingestion is not affected by co-ingestion of either carbohydrate or fat, whereas it is eliminated when protein is co-ingested with carbohydrate and fat. Again serum arginine concentrations are likely to be involved, since serum arginine concentrations are reduced after co-ingestion of carbohydrate and fat compared with ingestion of protein alone or co-ingestion with carbohydrate or fat, which indicates an interaction of carbohydrate, fat and protein with serum arginine concentrations. Another explanation for the reduced GH secretion after protein co-ingested with carbohydrate and fat compared with protein alone or combined with either carbohydrate or fat, may be the influence of the hormone ghrelin, known as GH secretagogue ${ }^{14}$. Ghrelin concentrations are decreased postprandially, dependent on the energy content of the meal. Protein combined with carbohydrate and fat will result in lower ghrelin concentrations postprandially compared with protein or protein plus carbohydrate or fat, due to the higher energy content ${ }^{15}$ and consequently will result in lower $\mathrm{GH}$ concentrations. With respect to insulin concentrations, we could not confirm their involvement in the eliminated GH response after soy plus carbohydrate plus fat, since insulin concentrations are equally increased after ingestion of the conditions protein plus carbohydrate and protein plus carbohydrate plus fat, although GH concentrations are only increased after ingestion of protein plus carbohydrates, but not after protein plus carbohydrate plus fat.

Thus the short term regulation of the somatotropic axis by protein is dependent on the AA composition of protein and the presence of other macronutrients, in which serum arginine concentrations seem the strongest and most clear $\mathrm{GH}$ stimulator. However, also other AAs are also involved. This conclusion is based on young women using oral contraceptives. Future research should focus on the underlying mechanisms to understand the release of $\mathrm{GH}$ after different protein types and in the interaction with intake of other macronutrients. Postprandial protein metabolism influenced by ingestion of different protein types as well as protein in the presence of carbohydrates and/or fat has to be further investigated. It remains to be elucidated, for instance, why AA concentrations are higher $300 \mathrm{~min}$ after inges- 
tion of protein plus carbohydrates than after protein alone and why the AA concentrations are decreased after co-ingestion of protein, carbohydrate and fat, compared with ingestion of protein alone. Furthermore the involvement of gender, estrogens, GHRH, somatostatin, FFA and ghrelin in the $\mathrm{GH}$ secretory response to ingestion of dietary protein intake (whether or not combined with other macronutrients) has to be investigated, in order to clarify the short term neuroendocrine regulation of the somatotropic axis by dietary protein.

\section{PHYSIOLOGY OF THE SOMATOTROPIC AXIS INFLUENCED BY PROTEIN}

\section{Linear growth}

We reported that ingestion of dietary protein stimulates the $\mathrm{GH}$ secretion acutely, dependent on its AA composition ${ }^{3,6,9,10}$. Furthermore, epidemiological studies have shown positive relationships between certain protein sources, linear growth and plasma levels of IGF-1 in children ${ }^{16-19}$. Our hypotheses that the best described GH promoting AA combination, i.e. arginine and lysine, would be associated with linear growth, is partly confirmed by our epidemiological study indicating a positive relationship between arginine intake, -but not protein or lysine intake- and linear growth in prepubertal girls ${ }^{20}$. This association between the intake of arginine and linear growth may be explained by the stimulation of the somatotropic axis by arginine, since arginine is a potent stimulator of $\mathrm{GH}$ secretion ${ }^{21}$ and $\mathrm{GH}$ plays an important role in the stimulation of linear growth ${ }^{18,22}$. The finding that only arginine intake was associated with linear growth, indicates that the ingestion of those protein sources, high in arginine, are the most potent $\mathrm{GH}$ stimulators, affecting linear growth in the long term. Relatively high amounts of arginine are available in products like nuts, seeds, milk, meat and fish. This finding may be used to propose a diet containing higher amounts of arginine, to stimulate linear growth in children who are too small for their age and have relatively low levels of $\mathrm{GH}$, but who are not classified as $\mathrm{GH}$ deficient. These children are not receiving $\mathrm{GH}$ therapy, but may still benefit from restoration of the low GH levels. Whether increasing arginine intake may be a suitable intervention in this group remains to be investigated. 


\section{Body composition}

Since GH influences several metabolic functions such as promoting lipolysis and protein synthesis, we hypothesized that the best described $\mathrm{GH}$ promoting $\mathrm{AA}$ combination, i.e. arginine and lysine, would be associated with a relatively lower fat mass index (FMI) and higher fat free mass index (FFMI). The results of our epidemiological studies point into the direction that the intake of arginine and lysine, indeed is negatively associated with FMI and positively with FFMI. At the same time, also associations were found between total protein intake and FMI or FFMI, which indicates that there is an effect of arginine and lysine, but also an effect of protein intake in general.

These observations are in accordance with the somatotropic effects of dietary protein in general $^{3,6,9,10}$ and the specific AAs ARG and LYS ${ }^{1,3,5}$ as well as with the concomitant effects of $\mathrm{GH}$ on the intermediary metabolism such as on glucose and fat oxidation and the indirect effect on muscle protein synthesis ${ }^{23}$. GH suppresses glucose oxidation and concomitantly stimulates lipolysis, resulting in a decreased fat mass index. Furthermore GH stimulates the production of IGF-1, which stimulates the signalling of the PI-3 kinase/ mTOR pathway, resulting in an increase in muscle protein synthesis rates ${ }^{24,25}$ and in an increase in FFMI in the long term. Other mechanisms through which protein stimulates muscle protein synthesis can be attributed to the potential of AAs to stimulate insulin secretion ${ }^{26}$. Insulin is known to stimulate muscle protein synthesis ${ }^{25,27}$. Furthermore, AAs may directly stimulate muscle anabolism via an activation of the mTOR pathway, resulting in enhanced protein synthesis ${ }^{24,28-30}$.

Hence, dietary protein intake, as well as intake of the specific AAs arginine and lysine is negatively associated with fat mass index, indicating a role for dietary protein in $\mathrm{GH}$ secretion and concomitantly in the stimulation of lipolysis, resulting in a decrease in fat mass index in the long term. Furthermore, the positive association between protein intake as well as that of the specific AAs arginine and lysine, and FFMI may be explained by its effect on GH and IGF-1 secretion, but also by the insulin tropic action of protein and the direct effect of serum AAs on the activation of the mTOR pathway. Future research should focus on intervention studies to clarify whether total protein ingestion or specific AAs as arginine and lysine are determining the above mentioned long term effects on body composition. 


\section{PATHOPHYSIOLOGY OF THE SOMATOTROPIC AXIS INFLUENCED BY DIETARY PROTEIN}

\section{Diagnosis of GH deficiency}

GH stimulation tests (GHSTs) are widely used to diagnose GH deficiency (GHD). Recombinant human $\mathrm{GH}(\mathrm{rhGH})$ is prescribed as therapy in children with GHD to stimulate their linear growth and improve their body composition. However, it is still unclear how to identify those patients who will benefit from this therapy ${ }^{31}$. Current GHSTs are pharmacological, stimulating GH release directly via only one single pathway in the complex physiological regulation of $\mathrm{GH}$ secretion, for instance via suppressing somatostatin release, stimulating $\mathrm{GHRH}$ release or via a decline in glucose concentrations (Figure 1). Stimulation of $\mathrm{GH}$ release via single pathways results in the induction of a high inter individual variation in test outcomes. The use of dietary protein as a stimulator of GH secretion in a GHST induces a more physiological way of stimulation, because oral ingestion of dietary protein affects $\mathrm{GH}$ secretion indirectly through multiple mechanisms, including gastrointestinal signals such as ghrelin ${ }^{32}$, endocrine signals such as insulin ${ }^{3}$, as well as changes in serum AA concentrations ${ }^{3}$, resulting in both a suppression of somatotsatin, stimulation of GHRH and decline in glucose concentrations (Figure 1).

In adult hyposomatotropism we found less variation (CV\%) in $\mathrm{GH}$ response after protein ingestion used as a GHST compared with the traditional use of GHRH in a pharmacological GHST ${ }^{33}$. Less variation in the test outcomes may indicate that the test outcome distinguishes better between groups, resulting in a higher sensitivity, specificity and reliability of the test.

The use of dietary protein as GH stimulation test may be a valuable addition to the existing GHSTs in the diagnostic work-up of GHD. Further research in children is necessary to evaluate the use of dietary protein as stimulus in a GHST with respect to sensitivity, specificity and reproducibility, which can be calculated one year after start of rhGH therapy, based on the increase in linear growth. Furthermore, the boundary between subjects who will and who will not benefit from rhGH therapy has to be examined. The cut-off level for $\mathrm{GH}$ concentrations after dietary protein ingestion as stimulus in a GHST should be lower than the cut-off level after pharmacological stimulators, i.e. approximately $4 \mu \mathrm{g} / \mathrm{L}$ in stead of $10 \mu \mathrm{g} / \mathrm{L}$ respectively. The administrated dosage of protein is physiological, i.e. orally ingested in amounts which could be present in our habitual diet, whereas the administrated dosage of the pharmacological stimulators is injected intravenously in non-physiological dosages (i.e. dosages which are not naturally present in the body in these amounts), which results in different magnitudes of GH stimulation. 


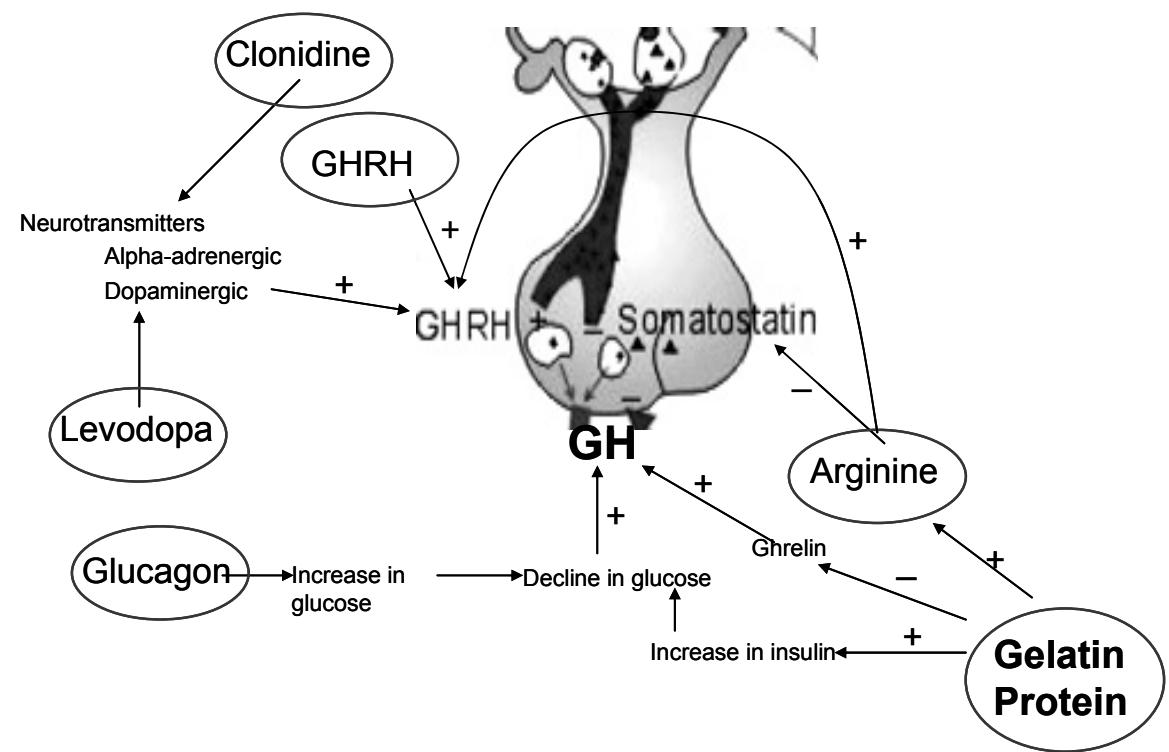

Figure 1: GH stimulation tests (GHSTs) are diagnostic tools to diagnose GHD in order to prescribe GH therapy in children. Pharmacological GHSTs advised by the consensus of the GH Research Society (1999) are: arginine, GHRH, clonidine, levo-dopa and glucagon. Arginine is suggested to stimulate the $\mathrm{GH}$ release via a suppression of somatostatin and a stimulation of GHRH; GHRH stimulates $\mathrm{GH}$ release via an increase in $\mathrm{GHRH}$; clonidine and levo-dopa stimulate $\mathrm{GH}$ secretion via neurotransmitters involving $\mathrm{GHRH}$ secretion; glucagon stimulates $\mathrm{GH}$ secretion via an increase of endogenous glucose production, resulting in a decline in glucose, which directly results in a stimulated $\mathrm{GH}$ secretion.

Gelatin protein as alternative physiological GHST influences GH secretion indirectly via: 1 . an increase in arginine concentrations, resulting in a suppression of somatostatin and a stimulation of GHRH; 2 . an increase in insulin secretion, resulting in a decline of glucose concentrations and subsequently in a stimulated GH secretion and; 3. a decrease in ghrelin, resulting in a decline of GH secretion.

\section{Visceral obesity}

Visceral fat mass is negatively related to the secretion of $\mathrm{GH}$; this condition of low GH secretion is denoted hyposomatotropism. Concomitantly with increased visceral fat mass, many other metabolic dysfunctions appear as reduced insulin sensitivity and unfavourable lipid profiles, resembling the metabolic syndrome ${ }^{34}$. Prolonged administration of rhGH results in reduced visceral adipose tissue, an improvement of insulin sensitivity and an improvement of lipid profiles. Since we found that dietary protein ingestion stimulated the somatotropic axis ${ }^{3,6,10}$, we hypothesized that dietary protein also could stimulate release of somatotropic axis in hyposomatotropism. We indeed confirmed this in one of the studies in this thesis ${ }^{33}$. Reduced basal GH concentrations are a typical characteristic in hyposomatotropism, however protein ingestion stimulates the $\mathrm{GH}$ secretion to concentra- 
tions comparable with $\mathrm{GH}$ concentrations in placebo-treated lean subjects with a normal functioning somatotropic axis.

The explanation for the reduced activity of the somatotropic axis in visceral obesity is not clear. On the one hand it may be that the somatotropic release is diminished for instance due to activation of the hypothalamic pituitary adrenal (HPA) axis as a result of increased cortisol concentrations in visceral obesity, resulting in increased concentrations of corticotrophin releasing hormone ( $\mathrm{CRH})$, decreased production of GH and consequently a decreased lipid oxidation and an excessive gain of fat tissue ${ }^{35}$. On the other hand it may be that an increase in fat mass indirectly reduces the secretion of $\mathrm{GH}$, for instance due to increased FFA concentrations, which is a characteristic of visceral obesity ${ }^{36}$ or due to increased insulin concentrations and peripheral insulin resistance, which also is a characteristic of visceral obesity, resulting in increased IGF-1 concentrations and therefore via a negative feedback to the suppression of $\mathrm{GH}$ release ${ }^{37-39}$. Furthermore, it could be that increased concentrations of leptin as a result of gain in fat mass ${ }^{40,41}$, reduce the $\mathrm{GH}$ secretion, as also increased cortisol concentrations as a result of gain in visceral fat mass ${ }^{35}$ may result in a reduced $\mathrm{GH}$ secretion.

The GH promoting activity of dietary protein in hyposomatotropism probably acts by the same mechanisms as in lean subjects. However, the above-mentioned factors such as higher FFA concentrations, higher insulin concentrations, and higher leptin and cortisol concentrations in visceral obese hyposomatotropic subjects probably prevent a peak concentration comparable to that in lean subjects. Despite the magnitude of stimulation of the somatotropic axis in hyposomatotropism is lower than in lean subjects, GH concentrations are increased, and reach levels that are found in placebo-treated, non-obese subjects. In the long term, this restoration of circulating $\mathrm{GH}$ concentrations probably will result in a reduction of fat mass (especially visceral fat mass), and a change of fat distribution from visceral to peripheral fat via an increase in the lipolysis, fat mobilisation, activation of hormone sensitive lipase, triglyceride hydrolysis and a decrease in fatty acid reesterfication ${ }^{42-44}$. Furthermore this restoration of $\mathrm{GH}$ concentrations by dietary protein ingestion may result in an increase in fat free mass, via increased rates of protein synthesis ${ }^{23,45}$.

The GH promoting effect of dietary protein in hyposomatotropism indicates a role of protein as nutritional intervention to improve body composition. Nowadays, GH therapy or oral ingestion of GHRH is used to improve body composition in hyposomatotropism, as visceral obese patients, sarcopenic patients or patients with human immunodeficiency virus (HIV) ${ }^{45-47}$. At this moment, only pharmacological interventions are available. We are the first in investigating a nutritional intervention to stimulate $\mathrm{GH}$ release. However this requires attention to the dietary pat- 
tern, since we know from our previous studies that the protein induced GH response is eliminated when protein is ingested combined with carbohydrate and fat and that the protein induced $\mathrm{GH}$ response occurs approximately $120 \mathrm{~min}$ after ingestion of protein. This results in a dietary pattern in which every 4 hours food is ingested as a two macronutrient meal high in protein. In the 1980s, Michael Montignac developed a diet where menus are designed to ingest limited combinations of macronutrients, which means that a meal should only consists of either a combination of protein with carbohydrates or protein with fat. Protein was allowed to be served at any time and indiscriminately with fat or carbohydrates. However the combination of carbohydrates and fat with protein should be avoided. Furthermore Montignac's method describes that meals should be ingested with at least 3-4 hours in between ${ }^{48}$. Such a diet is an example for a diet aiming to stimulate the $\mathrm{GH}$ release. However, in order to develop a diet stimulating $\mathrm{GH}$ release, the protein source is paramount, as different protein sources are known to differentially stimulate the GH secretion. Soy, alpha lactalbumin and milk protein stimulate the $\mathrm{GH}$ secretion to the same extent, gelatin protein is a stronger $\mathrm{GH}$ stimulator ${ }^{6}$. Furthermore, epidemiological studies reported that milk protein was associated with increased IGF-1 concentrations, as vegetable proteins and meat protein were not ${ }^{17,18}$. Moreover the specific quantity of fat or carbohydrate combined with protein intake may affect the $\mathrm{GH}$ promoting effect of protein. In our study the protein plus carbohydrate meal consisted of $69 \mathrm{En} \%$ carbohydrate and $31 \mathrm{En} \%$ protein. The protein plus fat meal consisted of en $44 \mathrm{En} \%$ fat and $56 \mathrm{En} \%$ protein ${ }^{10}$. In summary the GH promoting activity of dietary protein is also present in hyposomatotropism, resulting in a restoration of $\mathrm{GH}$ concentrations to a level comparable with placebo-treated non-hyposomatotropic subjects. A nutritional challenge to restore GH concentrations in hyposomatotropism should consist of four meals containing two macronutrients with at least $4 \mathrm{~h}$ in between.

\section{GENERAL CONCLUSIONS}

Effects of protein ingestion on enhancing the somatotropic activity were studied from a neuroendocrinological, physiological and pathophysiological perspective.

Short term neuroendocrine activation of the somatotropic axis by dietary protein intake is dependent on the AA composition of protein and the simultaneous intake of fat and carbohydrate, but independent on the chain length of protein or the intake of either carbohydrate or fat.

Habitual dietary protein intake is associated with growth in height and body composition. Arginine intake in particular is positively associated with an increase in 
linear growth. Protein intake in general, as well as intakes of arginine and lysine are associated with a decrease in fat mass index and an increase in fat free mass index in children.

At the level of the pathophysiology of the somatotropic axis, dietary protein ingestion as stimulus in a GH stimulation test (GHST) stimulates GH secretion in a physiological and multifactorial way, resulting in a lower inter individual variability of test outcomes compared with the unifactorial pharmacological stimuli traditionally used. Dietary protein ingestion as a diagnostic tool obviously discriminates between adult hyposomatotropism and non-hyposomatotropism with a low inter individual variability, and therefore seems to be an appropriate GHST in order to decide starting GH therapy in children with GHD.

Based upon our findings that dietary protein ingestion restores the low GH concentrations in hyposomatotropism, regular ingestion of milk or soy protein combined with either carbohydrates or fat with at least 4 hours in between the meals can be a valuable strategy to restore the somatotropic activity and concomitantly improve the body composition.

\section{FUTURE RESEARCH}

More specific short term as well as long term intervention studies on the $\mathrm{GH}$ promoting action of dietary protein need to be performed in order to develop recommendations to stimulate the somatotropic activity in hyposomatotropism. In our studies we found an involvement of serum AA concentrations in the short term somatotropic regulation by dietary protein, however some results remain unclear, for instance the reason why AA concentrations are higher 300 min after simultaneous ingestion of protein and carbohydrates than after protein alone and why the AA concentrations are decreased after simultaneous intake of protein, carbohydrate and fat, compared with ingestion of protein alone. Studies to investigate the AA metabolism with stable isotope techniques after ingestion of dietary protein, combined with other macronutrients will contribute to the understanding of the short term regulation of the somatotropic axis by dietary protein. Furthermore, serum concentrations of somatostatin, leptin, ghrelin, GHRH, cortisol, estrogens and FFA may play a role in the short term somatotropic activation by dietary protein and measuring these concentrations is of pivotal value in future short term experiments in order to clarify the neuroendocrinological short term regulation of the somatotropic axis by dietary protein.

From our studies it is known that dietary protein ingestion in the short term stimulates the somatotropic activity in a non-hyposomatotropic as well as in a hyposo- 
matotropic population. This effect however is dependent on the protein source and the presence of carbohydrate and fat. We also found in children that in the long term habitual arginine intake is positively associated with linear growth, and that dietary protein intake as well as the intake of the specific AAs arginine and lysine are associated with a decrease in fat mass index and an increase in fat free mass index. Future research should focus on the long term effects of a diet restoring circulating $\mathrm{GH}$ concentrations and concomitantly stimulating linear growth in hyposomatotropic children and improve body composition in hyposomatotropic (such as visceral obese) children and adults. Such a diet should consist of 4 meals, each with $4 \mathrm{~h}$ in between. Meals should consist of not more than two macronutrients, i.e. protein with either carbohydrate or fat. The protein source should be preferably milk, gelatin or soy. Linear growth in hyposomatotropic children, body composition, fat distribution, insulin sensitivity and lipid profiles in hyposomatotropic children and adults have to be measured before, 6 weeks, 3 months and 6 months after starting the intervention.

In our review we gave an overview of the sensitivity, specificity and reliability of the currently used unifactorial, pharmacological GHSTs and we suggested an alternative multifactorial physiological GHST, with dietary protein as stimulus. Concomitantly, we found that dietary protein as stimulus in a GHST obviously discriminates between adult hyposomatotropism and non-hyposomatotropism. A next step is to investigate whether dietary protein as a GH stimulus in a GHST is appropriate to predict the effect of rhGH on linear growth in children who are too small for their age. After one year of rhGH therapy, the predictive value of dietary protein (including sensitivity and specificity) as stimulus in a GHST with respect to the effect of rhGH on linear growth should be evaluated to examine the boundary between subjects who will benefit and will not benefit from GH therapy. 


\section{REFERENCES}

1. Isidori A, Lo Monaco A \& Cappa M. A study of growth hormone release in man after oral administration of amino acids. Curr Med Res Opin 19817 475-481.

2. Suminski RR, Robertson RJ, Goss FL, Arslanian S, Kang J, DaSilva S, Utter AC \& Metz KF. Acute effect of amino acid ingestion and resistance exercise on plasma growth hormone concentration in young men. Int J Sport Nutr 19977 48-60.

3. van Vught AJ, Nieuwenhuizen AG, Brummer RJ \& Westerterp-Plantenga MS. Effects of oral ingestion of amino acids and proteins on the somatotropic axis. J Clin Endocrinol Metab 200893 584-590.

4. Salway DSJ. Medical Biochemistry at a Glance

5. Knopf RF, Conn JW, Fajans SS, Floyd JC, Guntsche EM \& Rull JA. Plasma Growth Hormone Response to Intravenous Administration of Amino Acids. J Clin Endocrinol Metab 196525 1140-1144.

6. van Vught AJAH, Nieuwenhuizen AG, Gerver WJ, Veldhorst MAB, Brummer RJM \& WesterterpPlantenga MS. Somatotropic effects of soy-, gelatin-, alpha-lactalbumin- and milk protein. (In revision) 2009.

7. Fineberg SE, Horland AA \& Merimee TJ. Free fatty acid concentrations and growth hormone secretion in man. Metabolism 197221 491-498.

8. Frystyk J, Grofte T, Skjaerbaek C \& Orskov H. The effect of oral glucose on serum free insulin-like growth factor-I and -II in health adults. J Clin Endocrinol Metab 199782 3124-3127.

9. van Vught AJ, Nieuwenhuizen AG, Brummer RJ \& Westerterp-Plantenga MS. Somatotropic responses to soy protein alone and as part of a meal. Eur J Endocrinol 2008159 15-18.

10. van Vught JAH, Nieuwenhuizen AG, Veldhorst MAB, Brummer RJM \& Westerterp-Plantenga MS. Somatotropic effects of soyprotein in relation to the presence of carbohydrate and fat. E-spen (in press) 2009.

11. Veldhorst MAB, Westerterp MS \& Westerterp KR. Gluconeogenesis and energy expenditure after a high protein, carbohydrate-free diet. AJCN (in revision) 2009.

12. Ensinck JW, Vogel RE, Laschansky EC \& Francis BH. Effect of ingested carbohydrate, fat, and protein on the release of somatostatin-28 in humans. Gastroenterology 199098 633-638.

13. Lloyd KC, Maxwell V, Ohning G \& Walsh JH. Intestinal fat does not inhibit gastric function through a hormonal somatostatin mechanism in dogs. Gastroenterology 1992103 1221-1228.

14. Lorenzi T, Meli R, Marzioni D, Morroni M, Baragli A, Castellucci M, Gualillo O \& Muccioli G. Ghrelin: a metabolic signal affecting the reproductive system. Cytokine Growth Factor Rev 200920137 152.

15. le Roux CW, Patterson M, Vincent RP, Hunt C, Ghatei MA \& Bloom SR. Postprandial plasma ghrelin is suppressed proportional to meal calorie content in normal-weight but not obese subjects. J Clin Endocrinol Metab 200590 1068-1071.

16. Holmes MD, Pollak MN, Willett WC \& Hankinson SE. Dietary correlates of plasma insulin-like growth factor I and insulin-like growth factor binding protein 3 concentrations. Cancer Epidemiol Biomarkers Prev 200211 852-861.

17. Hoppe C, Molgaard C, Juul A \& Michaelsen KF. High intakes of skimmed milk, but not meat, increase serum IGF-I and IGFBP-3 in eight-year-old boys. Eur J Clin Nutr 200458 1211-1216.

18. Hoppe C, Udam TR, Lauritzen L, Molgaard C, Juul A \& Michaelsen KF. Animal protein intake, serum insulin-like growth factor I, and growth in healthy 2.5-y-old Danish children. Am J Clin Nutr 200480 447-452.

19. Ma J, Giovannucci E, Pollak M, Chan JM, Gaziano JM, Willett W \& Stampfer MJ. Milk intake, circulating levels of insulin-like growth factor-I, and risk of colorectal cancer in men. J Natl Cancer Inst 200193 1330-1336. 
20. van Vught JAH, Heitmann BL, Nieuwenhuizen AG, Andersen LB, Hasselstrom H, Veldhorst MAM, Brummer RJM \& Westerterp-Plantenga MS. Association between intake of dietary protein and 3ychange in body growth among normal and overweight 6y old boys and girls (CoSCIS). Public Health and Nutrition (in press) 2009.

21. Collier SR, Casey DP \& Kanaley JA. Growth hormone responses to varying doses of oral arginine. Growth Horm IGF Res 200515 136-139.

22. Veldhuis JD, Roemmich JN, Richmond EJ, Rogol AD, Lovejoy JC, Sheffield-Moore M, Mauras N \& Bowers CY. Endocrine control of body composition in infancy, childhood, and puberty. Endocr Rev 200526 114-146.

23. Moller N \& Jorgensen JO. Effects of Growth Hormone on Glucose, Lipid and Protein Metabolism in Human Subjects. Endocr Rev 2009.

24. Kimball SR \& Jefferson LS. Regulation of global and specific mRNA translation by oral administration of branched-chain amino acids. Biochem Biophys Res Commun 2004313 423-427.

25. Koopman R, Verdijk L, Manders RJ, Gijsen AP, Gorselink M, Pijpers E, Wagenmakers AJ \& van Loon L. Co-ingestion of protein and leucine stimulates muscle protein synthesis rates to the same extent in young and elderly lean men. Am J Clin Nutr 200684 623-632.

26. van Loon $L$, Saris WH, Verhagen $H$ \& Wagenmakers AJ. Plasma insulin responses after ingestion of different amino acid or protein mixtures with carbohydrate. Am J Clin Nutr 200072 96-105.

27. Garlick PJ, Fern M \& Preedy VR. The effect of insulin infusion and food intake on muscle protein synthesis in postabsorptive rats. Biochem J 1983210 669-676.

28. Bohe J, Low A, Wolfe RR \& Rennie MJ. Human muscle protein synthesis is modulated by extracellular, not intramuscular amino acid availability: a dose-response study. J Physiol 2003 552 315-324.

29. Volpi E, Kobayashi H, Sheffield-Moore M, Mittendorfer B \& Wolfe RR. Essential amino acids are primarily responsible for the amino acid stimulation of muscle protein anabolism in healthy elderly adults. Am J Clin Nutr 200378 250-258.

30. Proud CG. mTOR-mediated regulation of translation factors by amino acids. Biochem Biophys Res Commun 2004313 429-436.

31. Van vught JAH, Nieuwenhuizen AG, Gerver WJ, Veldhorst MAB, Brummer RJM \& WesterterpPlantenga MS. Pharmacological and physiological growth hormone stimulation tests to predict successful GH therapy in children JPEM (in press) 2008.

32. Nakagawa E, Nagaya N, Okumura H, Enomoto M, Oya H, Ono F, Hosoda H, Kojima M \& Kangawa K. Hyperglycaemia suppresses the secretion of ghrelin, a novel growth-hormone-releasing peptide: responses to the intravenous and oral administration of glucose. Clin Sci (Lond) 2002 103 325-328.

33. Van Vught AJ, Nieuwenhuizen A, Veldhorst MAB, Brummer RJ \& Westerterp ms. Acute ingestion of gelatin protein normalizes blunted GH concentrations in visceral obesity. submitted 2008.

34. Johannsson $\mathrm{G}$ \& Bengtsson BA. Growth hormone and the metabolic syndrome. J Endocrinol Invest 199922 41-46.

35. Bjorntorp P. Endocrine abnormalities of obesity. Metabolism 199544 21-23.

36. Buijs MM, Burggraaf J, Langendonk JG, Schoemaker RC, Frolich M, Arndt JW, Cohen AF, Romijn JA, Ackermans MT, Sauerwein HP, Meinders AE \& Pijl H. Hyposomatotropism blunts lipolysis in abdominally obese women. J Clin Endocrinol Metab 200287 3851-3858.

37. Brismar K, Fernqvist-Forbes E, Wahren J \& Hall K. Effect of insulin on the hepatic production of insulin-like growth factor-binding protein-1 (IGFBP-1), IGFBP-3, and IGF-I in insulin-dependent diabetes. J Clin Endocrinol Metab 199479 872-878.

38. Froesch ER, Guler HP, Schmid C, Binz K \& Zapf J. Therapeutic potential of insulinlike growth factor i. Trends Endocrinol Metab 19901 254-260.

39. Frystyk J, Vestbo E, Skjaerbaek C, Mogensen CE \& Orskov H. Free insulin-like growth factors in human obesity. Metabolism 199544 37-44.

40. Tuominen JA, Ebeling $P$, Heiman ML, Stephens $T$ \& Koivisto VA. Leptin and thermogenesis in humans. Acta Physiol Scand 1997160 83-87. 
41. Tuominen JA, Ebeling P, Laquier FW, Heiman ML, Stephens T \& Koivisto VA. Serum leptin concentration and fuel homeostasis in healthy man. Eur J Clin Invest 199727 206-211.

42. Dietz J \& Schwartz J. Growth hormone alters lipolysis and hormone-sensitive lipase activity in 3T3F442A adipocytes. Metabolism 199140 800-806.

43. Moller N, Jorgensen JO, Schmitz O, Moller J, Christiansen J, Alberti KG \& Orskov H. Effects of a growth hormone pulse on total and forearm substrate fluxes in humans. Am J Physiol 1990258 E86-91.

44. Ottosson M, Vikman-Adolfsson K, Enerback S, Elander A, Bjorntorp P \& Eden S. Growth hormone inhibits lipoprotein lipase activity in human adipose tissue. J Clin Endocrinol Metab 199580936 941.

45. Mekala KC \& Tritos NA. Effects of recombinant human growth hormone therapy in obesity in adults: a meta analysis. J Clin Endocrinol Metab 200994 130-137.

46. Falutz J, Allas S, Blot K, Potvin D, Kotler D, Somero M, Berger D, Brown S, Richmond G, Fessel J, Turner R \& Grinspoon S. Metabolic effects of a growth hormone-releasing factor in patients with HIV. N Engl J Med 2007357 2359-2370.

47. Pasarica M, Zachwieja JJ, Dejonge L, Redman S \& Smith SR. Effect of Growth Hormone on Body Composition and Visceral Adiposity in Middle Aged Men with Visceral Obesity. J Clin Endocrinol Metab 2007.

48. Dumesnil JG, Turgeon J, Tremblay A, Poirier P, Gilbert M, Gagnon L, St-Pierre S, Garneau C, Lemieux I, Pascot A, Bergeron J \& Despres JP. Effect of a low-glycaemic index--low-fat--high protein diet on the atherogenic metabolic risk profile of abdominally obese men. Br J Nutr 200186 557-568. 

Summary

Samenvatting 



\section{Summary}

The somatotropic axis, also known as the growth hormone (GH) - Insulin-like growth factor-1 (IGF-1) axis, originates in the hypothalamus and pituitary gland. Through the central release of GH and peripheral production of IGF-1, the somatotropic axis is involved in linear growth and intermediary metabolism. Disorders as visceral obesity and growth retardation in children are characterised by a low activity of the somatotropic axis. Repeated injection of $\mathrm{GH}$, also named $\mathrm{GH}$ therapy, decreases visceral adipose tissue, increases muscle mass and bone density and furthermore stimulates lineair growth in children. In addition to GH therapy, sleep, physical activity and nutrition influences the endogenous $\mathrm{GH}$ secretion. The latter is investigated in this thesis from a neuroendocrinologic, physiologic and pathophysiologic perspective.

From literature it is known that oral or intravenous administration of $A A$ is involved in the neuroendocrine regulation of the somatotropic axis. Arginine in combination with lysine, has been shown to stimulate the $\mathrm{GH}$ release potently. Since $A A$ are the building blocks of protein, it is likely that proteins, similar to $A A$, are involved in short term somatotropic regulation. In our studies we investigated the $\mathrm{GH}$ promoting effects of a mixture of 20 AAs, reflecting a dietary protein compared with a mixture of arginine and lysine. In both conditions the same amounts of arginine and lysine were present. We found that ingestion of a mixture of AA is more potent in stimulating $\mathrm{GH}$ release than ingestion of a mixture of arginine and lysine, which indicates that in addition to arginine and lysine, other AAs are directly or indirectly involved in the observed stimulation of $\mathrm{GH}$ release. Subsequently, we investigated the influence of the AA mixture, partially hydrolysed and complete protein on their GH secretory capacity and concluded that the chain length of protein is not of pivotal value for the $\mathrm{GH}$ response, since $\mathrm{GH}$ responses were similar after ingestion of a mixture of single AAs, a hydrolysed protein and a complete protein (chapter 2 ). The above-mentioned studies suggest that the GH secretory response to dietary protein is dependent on ingestion of the amount and type of AAs. This indication resulted in a study investigating the GH secretory capacity of different protein sources. The $\mathrm{GH}$ secretion after ingestion of soy, gelatin, alphalactalbumin and milk protein was investigated. Soy protein was hypothesized being the strongest GH stimulator among the proteins because of its relatively high content of arginine and lysine. However, this hypothesis was not confirmed by our study, in which we found that gelatin protein is a stronger $\mathrm{GH}$ stimulator than soy protein, alpha lactalbumin protein and milk protein. Alpha lactalbumin, milk and soy protein stimulate the $\mathrm{GH}$ response to a similar extent (chapter 3 ). 
Since a typical meal consumed by humans consists of a mixture of 3 macronutrients and not of protein alone, the interaction of ingested carbohydrates and/ or fat with the $\mathrm{GH}$ promoting effect of protein is studied. We found that the somatotropic effect of protein was eliminated when soy protein was ingested combined with carbohydrate and fat, however remained unchanged over 5 hours when protein was combined with either carbohydrate or fat. This indicates that in addition to protein, the combination of carbohydrate and fat plays a modulating role in the postprandial secretion of $\mathrm{GH}$ after ingestion of a meal (chapter $4+5$ ).

In addition to the short term neuroendocrine effects of protein ingestion on $\mathrm{GH}$ secretion, we studied the long term effects of protein ingestion on the somatotropic axis from a physiological perspective. Epidemiological observational cohort studies, each consisting of approximately 250 children, were used to investigate the associations between protein intake and in particular the amino acids arginine and lysine and linear growth, lean body mass and body fat mass in prepubertal and pubertal children over 3-6 years. The results of these studies indicate a positive relationship between arginine intake and linear growth and point into the direction that the intake of arginine and lysine, indeed is negatively associated with fat mass index (FMI) and positively with fat free mass index (FFMI). At the same time, also associations were found between total protein intake and FMI or FFMI, which indicates that there is an effect of arginine and lysine, but also an effect of protein intake in general (chapter $6+7$ ).

At the level of the pathophysiology of the somatotropic axis, we reviewed current used pharmacological tests to evaluate the activity of the somatotropic axis in order to diagnose GH deficiency in children who are too small for their age (chapter 8). Children with $\mathrm{GH}$ deficiency receive GH therapy. Current tests are pharmacological, stimulating $\mathrm{GH}$ release directly via only one single pathway in the complex physiological regulation of GH secretion. Stimulation of GH release via one single pathway results in the induction of a high inter individual variation in test outcomes. In this thesis, a new test, the dietary protein test, is proposed. The use of dietary protein as a stimulator of GH secretion induces a more physiological way of stimulation, because oral ingestion of dietary protein affects $\mathrm{GH}$ secretion indirectly through multiple mechanisms, resulting in a lower inter individual variability of test outcomes compared with the unifactorial pharmacological stimuli traditionally used.

In order to investigate whether the somatotropic effect of dietary protein is also present in (adult) hyposomatotropism, and whether ingestion of dietary protein can be used as a diagnostic tool to discriminate between adult hyposomatotropism and non-hyposomatotropism, we executed a study to compare the GH promoting effect of dietary protein in lean subjects (non-hyposomatotropic) and visceral obese subjects (hyposomatotropic). The hyposomatotropic state was confirmed by measuring the $\mathrm{GH}$ response to $\mathrm{GHRH}$. This study shows that oral intake of a dietary 
protein stimulates the $\mathrm{GH}$ secretion in lean as well as in visceral obese subjects. Ingestion of dietary protein showed to be an adequate method to discriminate between adult hyposomatotropism and non-hyposomatotropism, with a low inter individual variability compared to GHRH administration, and therefore may be an appropriate test in order to diagnose GHD (chapter 9).

Reduced basal GH concentrations are a typical characteristic in hyposomatotropism, however, protein ingestion stimulates the $\mathrm{GH}$ secretion in visceral obese subjects to concentrations comparable with $\mathrm{GH}$ concentrations in placebo-treated lean subjects with a normal functioning somatotropic axis (chapter 9).

Based on the results reported in this thesis, it is concluded that the short term neuroendocrine activation of the somatotropic axis by dietary protein intake is dependent on the AA composition of protein and the simultaneous intake of fat and carbohydrate, but independent of the chain length of protein or the intake of either carbohydrate or fat. Habitual dietary protein intake is associated with growth in height and body composition. Arginine intake in particular is positively associated with an increase in linear growth. Protein intake in general, as well as intakes of arginine and lysine are associated with a decrease in fat mass index and an increase in fat free mass index in children. Furthermore, dietary protein ingestion stimulates $\mathrm{GH}$ secretion in a physiological way, resulting in a lower inter individual variability of test outcomes compared with the unifactorial pharmacological stimuli traditionally used and therefore seems to be an appropriate test in order to decide starting GH therapy in children with GHD. Finally, based upon our findings that dietary protein ingestion restores the low $\mathrm{GH}$ concentrations in hyposomatotropism of visceral obesity, regular ingestion of milk or soy protein combined with either carbohydrates or fat can be a valuable strategy to restore the somatotropic activity and concomitantly improve the body composition. 



\section{Samenvatting}

De somatotrofe as, ook wel de groeihormoon (GH) / insulin-like growth factor-1 (IGF-1) as genoemd, heeft zijn oorsprong in de hypothalamus en hypofyse. $\mathrm{GH}$ wordt afgegeven door de hypofyse en stimuleert de afgifte van IGF-1 in de lever en spieren, wat invloed heeft op de lengtegroei en het intermediaire metabolisme. Lage $\mathrm{GH}$ afgifte komt onder andere voor bij individuen met viscerale obesitas en bij kinderen die te klein zijn voor hun leeftijd. Het herhaaldelijk injecteren van $\mathrm{GH}$, ook wel GH therapie genoemd, leidt tot een daling van de viscerale vetmassa, verhoging van de spiermassa en botdichtheid, en tevens tot een toename van de lengtegroei bij kinderen. Naast het injecteren van GH kan de GH afgifte endogeen gestimuleerd worden door slaap, fysieke activiteit en door voeding. Dit laatste aspect is in dit proefschrift onderzocht vanuit een neuro-endocrinologische, fysiologische en pathofysiologische invalshoek.

Uit de literatuur is bekend dat orale of intraveneuze toediening van aminozuren (AA) de neuro-endocriene regulatie van de somatotrofe as beïnvloedt. Voornamelijk de combinatie van de AA arginine en lysine is bekend als een sterke stimulator van de $\mathrm{GH}$ afgifte. Eiwitten bestaan uit $\mathrm{AA}$ en daarom is het aannemelijk dat eiwitten, net als $A A$, betrokken zijn bij de korte termijn regulatie van de somatotrofe as. Allereerst hebben we onderzocht of een AA oplossing, waarin alle $20 \mathrm{AA}$ van een eiwit aanwezig zijn, de GH afgifte sterker stimuleert dan een oplossing van arginine en lysine. In beide oplossingen waren gelijke hoeveelheden arginine en lysine aanwezig. We namen waar dat de afgifte van GH sterker was na inname van de AA oplossing dan na de arginine en lysine oplossing, wat duidt op een direct of indirect effect van ook andere AA dan arginine en lysine op de GH afgifte. Vervolgens onderzochten we het effect van ketenlengte van een eiwit op de $\mathrm{GH}$ afgifte. Hiertoe werd de GH afgifte na inname van de AA oplossing, gedeeltelijk gehydrolyseerd eiwit en compleet eiwit bepaald. Er was geen verschil in GH afgifte na de AA oplossing, het gehydrolyseerde eiwit en het complete eiwit, wat betekent dat de ketenlengte van een eiwit niet van invloed is op de GH afgifte (hoofdstuk 2).

Bovenstaande experimenten suggereren dat de aanwezigheid van bepaalde AA bepalend is voor de mate van $\mathrm{GH}$ afgifte. Deze aanwijzing resulteerde in de studie naar de invloed van verschillende eiwitten (en dus verschillende AA samenstellingen) op de afgifte van $\mathrm{GH}$. De GH afgifte na inname van soja, gelatine, alphalactalbumine en melk eiwit werd vergeleken. De hypothese stelde dat soja eiwit de $\mathrm{GH}$ afgifte het sterkst stimuleert in vergelijking met andere eiwitten, omdat soja eiwit relatief rijk is aan arginine en lysine. Deze hypothese werd niet bevestigd door onze studie, waar we vonden dat na inname van gelatine eiwit de $\mathrm{GH}$ afgifte het sterkst 
steeg in vergelijking met de andere eiwitten, en dat alpha lactalbumine, melk en soja eiwit in gelijke mate in staat zijn de postprandiale $\mathrm{GH}$ respons te verhogen (hoofdstuk 3).

Omdat eiwitten in het dagelijks leven worden ingenomen in combinatie met koolhydraten en vetten, is onderzocht of het effect van eiwitten op de stimulatie van $\mathrm{GH}$ afgifte ook aanwezig is wanneer eiwitten worden ingenomen in combinatie met koolhydraten en/ of vetten. In deze studies vonden we dat de respons van eiwit inname op de GH afgifte was verdwenen wanneer inname van eiwit werd gecombineerd met inname van koolhydraten en vetten. Dit respons werd echter niet beïnvloed wanneer inname van eiwitten werd gecombineerd met inname van koolhydraten of vetten. Deze bevindingen zijn een aanwijzing dat naast eiwitten, de aanwezigheid van koolhydraten en vetten bepalend is in de afgifte van GH na een maaltijd (hoofdstuk 4+5).

Naast de neuro-endocriene effecten van eiwit inname op de acute afgifte van GH hebben we de lange termijn effecten van eiwit inname en de inname van de AA arginine en lysine op de somatotrofe as bekeken vanuit een fysiologisch perspectief. In deze studies hebben we met behulp van twee databases, elk bestaande uit ongeveer 250 kinderen, mogelijke associaties bestudeerd tussen de inname van eiwitten en de specifieke AA arginine en lysine en de 3-6 jaars ontwikkeling van lichaamssamenstelling en lengtegroei bij prepuberale en puberale kinderen. In deze studies is een positieve associatie gevonden tussen de inname van arginine en de lentegroei. Verder is gevonden dat de totale eiwit inname, net als de inname van de AA arginine en lysine, geassocieerd is met een afname van de vetmassa en een toename van de vet vrije massa (gecorrigeerd voor de lichaamslengte) wat duidt op een effect van arginine en lysine, maar ook op een effect van de totale eiwit inname op de lichaamssamenstelling (hoofdstuk 6+7).

Met betrekking tot de pathofysiologie van de somatotrofe as, hebben we in een overzichtsartikel verschillende testen geëvalueerd, die de activiteit van de somatotrofe as weergeven (hoofdstuk 8). Deze testen worden gebruikt in het diagnostisch proces om GH deficiëntie vast te stellen bij kinderen die te klein zijn voor hun leeftijd. Kinderen met $\mathrm{GH}$ deficiëntie komen in aanmerking voor $\mathrm{GH}$ therapie. De afgifte van GH is complex, wat betekent dat deze op vele manieren wordt beïnvloed. De huidig gebruikte instrumenten zijn op farmacologische basis en stimuleren de afgifte van $\mathrm{GH}$ op slechts één manier, wat leidt tot een hoge interindividuele variatie van de testuitslag. In dit proefschrift wordt een nieuwe test voorgesteld om GH deficiëntie vast te stellen. In deze test worden eiwitten oraal toegediend waarna de postprandiale $\mathrm{GH}$ respons bepaald wordt. Eiwitten stimuleren de $\mathrm{GH}$ afgifte op verschillende manieren, wat leidt tot een meer fysiologische wijze van $\mathrm{GH}$ stimulatie en daardoor tot een kleinere inter-individuele variatie van de testuitslag in vergelijking met de farmacologische testen. 
Vervolgens hebben we onderzocht of de bovengenoemde effecten van eiwitten op de stimulatie van $\mathrm{GH}$ afgifte ook in populaties met een verminderde werking van de somatotrofe as (hyposomatotroof) te vinden zijn en of orale inname van eiwit gebruikt kan worden als diagnostisch instrument om een onderscheid te maken tussen personen met en zonder hyposomatotropisme (hoofdstuk 9). Hiertoe werden slanke volwassen personen (zonder hyposomatotropisme) en visceraal obese personen (hyposomatotroof) met elkaar vergeleken op de $\mathrm{GH}$ afgifte na inname van eiwitten. De mate waarin personen in staat zijn om $\mathrm{GH}$ af te geven werd gemeten door de $\mathrm{GH}$ afgifte na intraveneuze toediening van $\mathrm{GH}$ releasing hormone (GHRH test) te bepalen. Gebleken is dat de $\mathrm{GH}$ afgifte na eiwit inname, net als in slanke personen, is gestimuleerd in visceraal obese personen en dat deze stimulatie de verlaagde $\mathrm{GH}$ concentraties in visceraal obese personen verhoogt tot concentraties vergelijkbaar met de niet-gestimuleerde $\mathrm{GH}$ concentraties in slanke personen. Tevens hebben we ontdekt dat orale inname van eiwit een duidelijk onderscheidt maakt tussen mensen met hyposomatotropisme en mensen zonder hyposomatotropisme met een lagere inter individuele variatie van de testuitslag in vergelijking met de GHRH test. Hieruit concluderen we dat de eiwit test een geschikt instrument lijkt om GH deficiëntie te diagnosticeren (hoofdstuk 9).

Uit de resultaten beschreven in dit proefschrift kan worden geconcludeerd dat het korte termijn effect van eiwitten in de voeding op de afgifte van $\mathrm{GH}$ af hangt van de eiwit bron en de aanwezigheid van koolhydraten en vetten in de voeding, maar niet af hangt van de eiwit ketenlengte of de aanwezigheid van koolhydraten of vetten. Dagelijkse eiwit inname is geassocieerd met groei in de lengte en breedte. Arginine inname is geassocieerd met groei in de lengte. Inname van eiwitten en inname van arginine en lysine zijn geassocieerd met een afname van de vet massa index en toename van de vetvrije massa index. Verder werd gevonden dat voedingseiwit de $\mathrm{GH}$ afgifte fysiologisch stimuleert, wat resulteert in een lage inter individuele variabiliteit van de testuitslag, vergeleken met de huidige farmacologische testen. Eiwit inname lijkt dus een geschikt diagnostisch instrument om GH deficiëntie vast te stellen. Tenslotte, gebaseerd op de vinding dat voedingseiwitten de lage $\mathrm{GH}$ concentraties herstellen in hyposomatotropisme bij visceraal obsitas, kan gesteld worden dat regelmatige inname van melk of soja eiwit, gecombineerd met koolhydraten of vetten een adequate strategie is om de verminderde werking van de somatotrofe as in viscerale obesitas te herstellen met als doel de lichaamssamenstelling te verbeteren. 



\section{Dankwoord}

Na vier drukke en zeer leerzame jaren is het dan zover, mijn proefschrift is klaar! Het dankwoord is het laatste stukje wat nog rest, waarin ik allereerst aandacht wil besteden aan Arie, Margriet en Robert-Jan. Jullie hebben mij de kans gegeven om te bereiken wat ik jaren geleden echt nooit voor mogelijk had geacht, zoals het internationaal presenteren en publiceren! Bedankt!

Arie... het altijd even binnen kunnen stappen tussen de bedrijven door heeft je een heel direct betrokken begeleider gemaakt, wat ik erg heb gewaardeerd. Kleine puntjes kon ik direct met je bespreken en je aanstekelijke enthousiasme over mijn nieuwe data heeft geleid tot vele interessante discussies.

Margriet... mijn waardering voor alles wat je hebt bereikt! Ondanks je drukke bestaan sta je wereldwijd altijd voor je AIO's klaar, wat mede heeft bijgedragen aan het succesvol en binnen vier jaar afronden van deze promotie! Tevens wil ik je bedanken voor de mogelijkheid die je gaf voor de vele (buitenlandse) tripjes, die altijd erg geslaagd waren!

Robert-Jan... jouw klinische groeihormoonexpertise, die je met veel enthousiasme overbracht heb ik erg gewaardeerd. Bedankt dat je, ondanks je drukke bestaan, de tijd nam om te discussiëren over onderzoekplannen en resultaten.

Next I would like to thank all the members of the reviewing committee; Prof. Dr. K. Westerterp, Dr. G. Johannsson, Prof. Dr. W. Lamers, Dr. C. Noordam and Prof. Dr. N Schaper and for their critical assessment of my dissertation.

Dear Prof. Dr. Berit Heitman, thank you very much for giving me the opportunity to work in your institute. Besides the fact that I learned a lot about epidemiology, it was a great experience! Also many thanks to the EEK-girls, Birgit, Helle, Nanne, Amanda and Charlotte, for a great and in many ways interesting period. Helene thank you for your friendship in Copenhagen and Maastricht! Mange tak!!!

Twee hele belangrijke collega's zijn nu aan de beurt, mijn paranimfen.

Margriet... Vanaf mijn eerste dag heb ik heel fijn met jou samengewerkt. De praktische kant van het onderzoek heb ik mede door jou geleerd! Je bent een oprechte collega, waarmee ik alles kon bespreken, wetenschappelijk en privé! Onze discussies over aminozuren, eiwitjes, glucoses en insulines heb ik erg gewaardeerd. Ik vind het fantastisch dat we samen gaan promoveren en hoop dat we in de toekomst nog veel contact blijven houden! 
Rick... na mijn Kopenhagen avontuur leerde we elkaar kennen als collega's. Als je met elkaar een kantoor deelt leer je elkaar snel goed kennen! Je gezelligheid en sociale persoonlijkheid met de nodige grappen (haha vooral bij andere collega's) kan ik erg waarderen. Heel veel succes met het afronden van je promotie!

Verder mijn clustergenoten... Stijn, Sofie, Sanne, Mieke, Marcel, Jurriaan, Guy, Femke, Astrid, Ananda, Andrea en Alberto, bedankt voor de fijne en leerzame tijd in Maastricht en de gezelligheid tijdens de congressen, cursussen en jullie bezoek in Kopenhagen. Veel succes met jullie verdere carrière! HB-(ex)collega's bedankt voor de gezellige thee/vlaai-pauzes en uitstapjes! Stagiaires, bedankt voor alle hulp. Hanne super dat je AIO bent geworden, heel veel succes de komende jaren!

Stein's lab... Ruud, Don, alle analisten en de dames van het kantoor in Maastricht, heel erg bedankt voor het ophalen, analyseren en uiteindelijk bezorgen van alle groeihormoon, insuline, glucose en amino zuur data!

ICT-mannen \& HB-secretaresses... heel erg bedankt voor alle hulp! Jurriaan, bedankt voor de acute -mijn computer doet weer raar- hulp op het werk! Thijs, super dat je altijd voor onze computer of internet problematieken in Cuijk klaarstaat!

Vriendinnen en vrienden... na de middelbare school zijn we allemaal onze eigen weg gegaan, wat heeft geleid tot zeer diverse leventjes! Jullie belangstelling voor mijn keuzes en werk, wat misschien niet altijd helemaal te begrijpen was, kan ik erg waarderen. Jullie bezoekjes aan Kopenhagen waren super, bedankt!! Vriendinnen uit Maastricht, in het bijzonder Monique, bedankt voor jullie interesse en de gezellige lunches $\&$ diners tussen de bedrijven door!

Verder wil ik graag onze families, muziekdocenten en tennisvriendinnen bedanken voor jullie interesse en de gezellige momenten buiten het werk!

Pap en mam... doorzetten, inzet, oplossingsvermogen en een positieve levensinstelling heb ik van jullie meegekregen en daarmee kom je een heel eind! Bedankt voor jullie altijd luisterend oor, interesse en trots!

Arno... bedankt voor je (inhoudelijke) interesse, de taxi naar Kopenhagen en de gezellige, sportieve en ontspannende zondag fiets tripjes!

Ruud... na lange dagen naar, in en terug van Maastricht was het erg fijn dat jij thuis op mij zat te wachten om samen te dineren en onze dagen even door te spreken, waarbij jouw relativerend vermogen van olifanten muggen maakte. Ik denk dat we elkaar is onze enthousiasme en inzet erg motiveren om het uiterste te kunnen bereiken. Bedankt voor wie je bent!

Op naar de toekomst! 


\section{Curriculum Vitae}

Anneke van Vught was born on May $24^{\text {th }} 1982$ in Boxmeer. In 1999, she completed secondary school at the 'Elzendaal College' in Boxmeer. In the same year she started her bachelor education of nursing at the HAN University of Applied Sciences, where she graduated in July 2003. In August 2003 she started her master education; Health Sciences with specialization Movement Sciences at Maastricht University, where she graduated in 2005.

In January 2006, Anneke started working at the department of Human Biology, Maastricht University on a project of Top Institue Food \& Nutrition. She studied the effects of dietary protein in the regulation of the somatotropic axis, under supervision of Prof. M.S. Westerterp-Plantenga, Prof. R-J.M. Brummer and Dr. A.G. Nieuwenhuizen. The research performed in this period is described in this thesis. In 2008, she was awarded a $2^{\text {nd }}$ place 'Foppe ten Hoor' young investigator award by the Netherlands Organisation of Scientific Research (NWO) for her work on the somatotropic effects of soy protein in the presence of carbohydrate and/or fat.

Currently Anneke is working on the master program of Physician Assistant at the HAN University of Applied Sciences. 


\section{List of publications}

\section{FULL PAPERS}

JAH van Vught, AG Nieuwenhuizen, R-JM Brummer, MS Westerterp-Plantenga; Effects of oral ingestion of amino acids and proteins on the somatotropic axis. J Clin Endocrinol Metab, 2008. 93(2): p. 584-90

JAH van Vught, AG Nieuwenhuizen, R-JM Brummer, MS Westerterp-Plantenga; Somatotropic responses to soy protein alone and as part of a meal. Eur J Endocrinol, 2008.159(1): p. 15

MA Veldhorst, AG Nieuwenhuizen, A Hochstenbach-Waelen, JAH van Vught, KR Westerterp, MPKJ Engelen, RJ Brummer, NEP Deutz, MS Westerterp-Plantenga; Dose depending satiating effects of whey relative to casein and soy. Physiol \& Behaviour, 2009. 96(4-5): p. 675-682

JAH van Vught, BL Heitmann, AG Nieuwenhuizen, MA Veldhorst, R-JM Brummer, MS Westerterp-Plantenga; Association between dietary protein intake and 6y-change in body composition among children (EYHS). In press, Clinical Nutrition, 2009

JAH van Vught, AG Nieuwenhuizen, MA Veldhorst, R-JM Brummer, MS WesterterpPlantenga; Somatotropic effects of protein in relation to the presence of other macronutrients. In press, e-SPEN journal, 2009

JAH van Vught, AG Nieuwenhuizen, MA Veldhorst, WJ Gerver, R-JM Brummer, MS Westerterp-Plantenga; Review: Pharmacological and physiological tests to predict successful GHtherapy. In press, J Ped Endocrinol Metab, 2009

JAH van Vught, BL Heitmann, AG Nieuwenhuizen, MA Veldhorst, R-JM Brummer, MS Westerterp-Plantenga; Association between dietary protein intake and $3 y$-change in growth in height and width among children (CoSCIS). In press, Publ Health Nutr, 2009

JAH van Vught, AG Nieuwenhuizen, MA Veldhorst, R-JM Brummer, MS WesterterpPlantenga; Somatotripic responses of soy, gelatin, alpha lactalbumin and milk. In revision, 2009

JAH van Vught, AG Nieuwenhuizen, MA Veldhorst, R-JM Brummer, MS WesterterpPlantenga; Acute ingestion of gelatin protein normalizes blunted $\mathrm{GH}$ concentrations in visceral obesity. Submitted for publication, 2009 
MAB Veldhorst, KR Westerterp, AJAH van Vught, MS Westerterp-Plantenga. Protein-induced appetite suppression is affected by the presence or absence of carbohydrates. Submitted for publication, 2009

\section{BOOK CHAPTER}

Veldhorst MAB, van Vught JAH, Westerterp-Plantenga MS. The effects of casein-, whey-, and soy protein on satiety, energy expenditure, and body composition. In: Weight control and slimming ingredients, Wiley and Blackwell Publishing, In press, 2009

\section{PRESENTATIONS}

Anneke JAH van Vught, Arie G Nieuwenhuizen, Robert-Jan M Brummer, Margriet S Westerterp-Plantenga. Effects of oral ingestion of amino acids and proteins on the somatotropic axis. SSIB 2007, Steamboatsprings, US.

Anneke JAH van Vught, Arie G Nieuwenhuizen, Robert-Jan M Brummer, Margriet S Westerterp-Plantenga. The role of proteins and amino acids on growth. Symposium Dietary protein 2007, Copenhagen, Denmark.

Anneke JAH van Vught, Arie G Nieuwenhuizen, Robert-Jan M Brummer, Margriet S Westerterp-Plantenga. Effects of soyprotein alone or as part of a meal on the somatotropic axis. ECO 2008, Geneva, Switzerland. Int J Obesity 2008;32(1):S100

Anneke JAH van Vught, Berit L. Heitmann, Arie G Nieuwenhuizen, Margriet AB Veldhorst, Robert-Jan M Brummer, Margriet S Westerterp-Plantenga. Association between dietary protein and 6y-change in body composition among normal and overweight 9y old boys and girls (EYHS). ECO 2008, Geneva, Switzerland. Hot topic

Anneke JAH van Vught, Arie G Nieuwenhuizen, Robert-Jan M Brummer, Margriet S Westerterp-Plantenga. Effects of oral ingestion of amino acids, proteins and a meal on the somatotropic axis. ENP 2008, Doorwerth, The Netherlands. Invited speaker

Anneke JAH van Vught, Arie G Nieuwenhuizen, Robert-Jan M Brummer, Margriet S Westerterp-Plantenga. Effects of soyprotein alone or as part of a meal on the somatotropic axis. SSIB 2008, Paris, France. Appetite 2008;51:407

Anneke JAH van Vught, Berit L Heitmann, Arie G Nieuwenhuizen, Margriet AB Veldhorst, Robert-Jan M Brummer, Margriet $S$ Westerterp-Plantenga. Association between dietary protein and 6y-change in body composition among normal and overweight $9 y$ old boys and girls (EYHS). SSIB 2008, Paris, France. Appetite 2008;51:407 
Anneke JAH van Vught, Berit L Heitmann, Arie G. Nieuwenhuizen, Margriet A.B. Veldhorst, Robert-Jan M. Brummer, Margriet S. Westerterp-Plantenga. Association between dietary protein and 6y-change in body composition among normal and overweight 9y old boys and girls (EYHS). E-spen 2008, Florence, Italy. Clinical Nutrition Supplements 2008;3(1):187

Anneke JAH van Vught, Arie Nieuwenhuizen. Somatotropic effects of soyprotein in the presence of other macronutrients. NWO 2008, Deurne, The Netherlands.

Anneke JAH van Vught, Arie G Nieuwenhuizen, Margriet AB Veldhorst, Robert-Jan M Brummer, Margriet S Westerterp-Plantenga. Somatotropic effects of soyprotein in the presence of other macronutrients. 1st Swiss Winterconference on ingestive behaviour 2009, St. Moritz, Switzerland. Invited speaker

Anneke JAH van Vught, Arie G Nieuwenhuizen, Margriet AB Veldhorst, Robert-Jan M Brummer, Margriet $S$ Westerterp-Plantenga. Somatotropic effects of soyprotein in the presence of other macronutrients. ECO 2009, Amsterdam, The Netherlands. Int J Obesity 2009;2(2):152

Anneke JAH van Vught, Berit L Heitmann, Arie G Nieuwenhuizen, Margriet AB Veldhorst, Robert-Jan M Brummer, Margriet S Westerterp-Plantenga. Association between intake of dietary protein and 3y-change in body growth among normal and overweight 6y old boys and girls (CoSCIS). ECO 2009, Amsterdam, The Netherlands. Int J Obesity 2009;2(2):110

Anneke JAH van Vught, Arie G Nieuwenhuizen, Margriet AB Veldhorst, Robert-Jan M Brummer, Margriet $S$ Westerterp-Plantenga. Somatotropic responses to soyprotein, gelatin protein, alpha-lactalbumin protein and milk protein. ECO 2009, Amsterdam, The Netherlands. Int J Obesity 2009;2(2):152

Anneke JAH van Vught, Arie G Nieuwenhuizen, Margriet AB Veldhorst, Robert-Jan M Brummer, Margriet S Westerterp-Plantenga. Acute ingestion of gelatin protein increases blunted GH concentrations in visceral obesity. 10th Benjamin Franklin Lafayette 2009, Frejus, France. Invited speaker

Anneke JAH van Vught, Arie G Nieuwenhuizen, Margriet AB Veldhorst, Robert-Jan M Brummer, Margriet $S$ Westerterp-Plantenga. Acute ingestion of gelatin protein increases blunted GH concentrations in visceral obesity. E-spen 2009, Vienna, Austria. Nutrition and Metabolism - the ESPEN Journal 2009; in press. 